Yilmaz Mehmet

\title{
A TÖRÖK POLITIKAI RENDSZER ÁTALAKULÁSA 2002 ÉS 2018 KÖZÖTT
}


Nemzetközi Tanulmányok Intézet

Témavezető:

Dr. Csicsmann László

egyetemi docens 


\section{Budapesti Corvinus Egyetem \\ Nemzetközi Kapcsolatok Multidiszciplináris Doktori Iskola}

A török politikai rendszer átalakulása 2002 és 2018 között

doktori értekezés

Yilmaz Mehmet

Budapest, 2019. 


\section{Tartalomjegyzék}

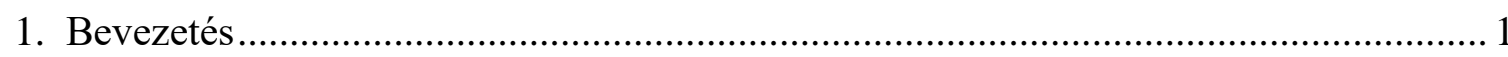

1.1 A disszertációval kapcsolatban áttekintendő szakirodalom ................................ 5

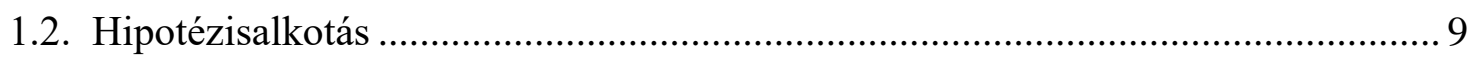

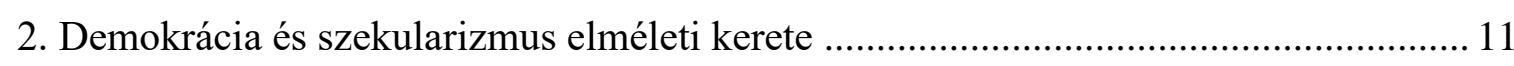

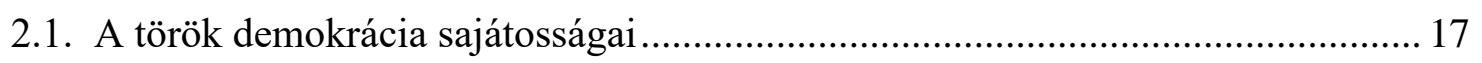

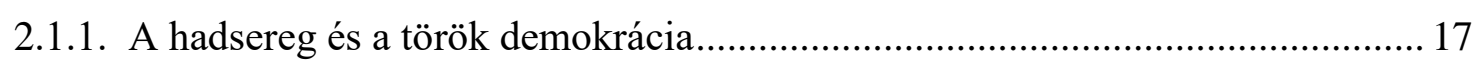

2.1.2. A szekularizmus és a demokrácia Törökországban .................................. 21

2.2. A török demokrácia története, a mai pártrendszer kialakulása ............................ 27

2.2.1. A köztársaság kikiáltása, az atatürki reformok ........................................... 27

2.2.2. Törökország demokratikus fordulata az 50-es években ............................... 28

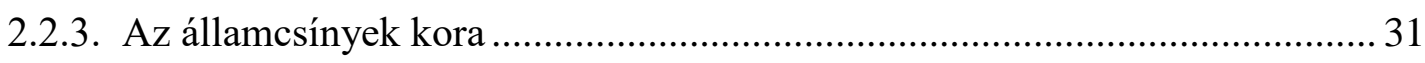

2.2.4. A rövid életü koalíciós kormányok időszaka .............................................. 32

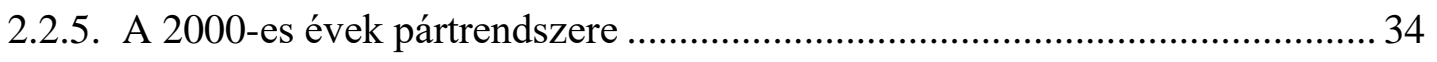

2.3. Az AK Parti ideológiája, története és kormányzati müködése.............................. 35

2.3.1. Az AK Parti közvetlen előzménye: Menderes és Özal öröksége.................... 35

2.3.2. Az AK Parti közvetlen előzménye: Erbakan öröksége ................................. 36

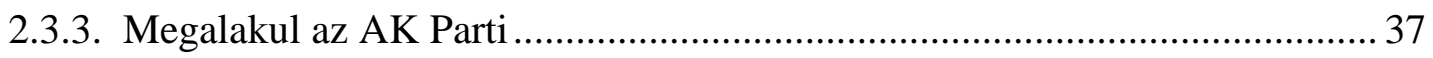

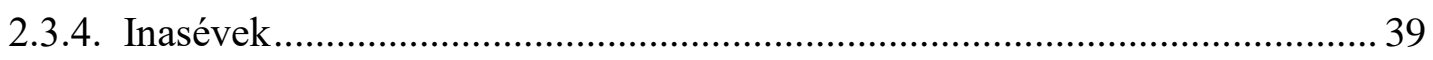

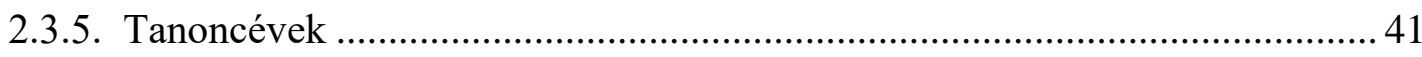

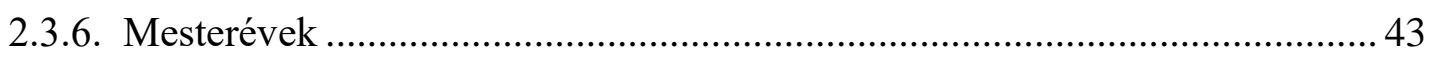

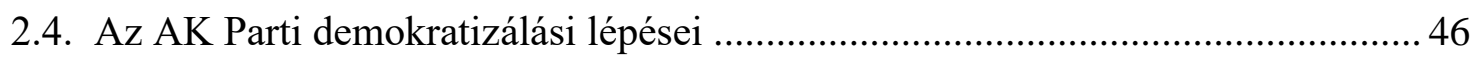

2.4.1. Az uniós csatlakozási tárgyalások hatása a törvényhozásra és a

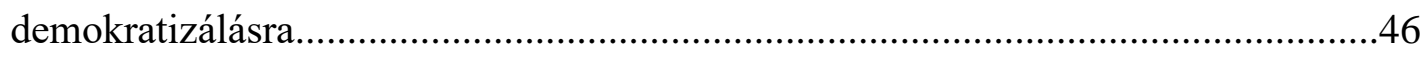

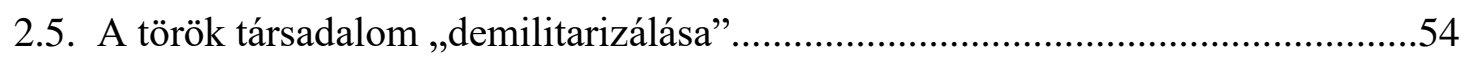

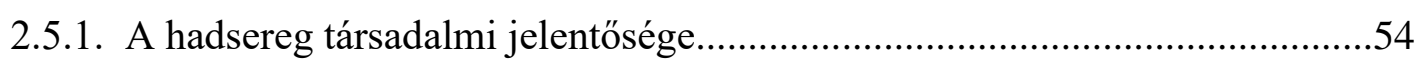

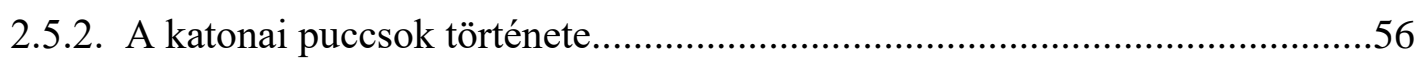


2.5.3. A hadsereg háttérbe szorítása az euroatlanti integráció és a demokratikus

átmenet érdekében

2.5.4. A hadsereg posztmodern válasza: a 2007. április 27-i sajtónyilatkozat. 66

2.5.5. A 21. század katonai hátterü puccskísérletei. 67

2.6. Az etnikai és vallási kisebbségek helyzete 70

2.6.1. A kisebbségek helyzete mint az európai integráció egyik előfeltétele........... 70

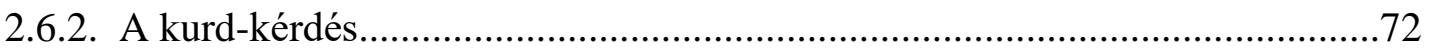

2.6.2.1. A kurdok helyzete az Oszmán Birodalomban..........................................72

2.6.2.2. A kurd kérdés kezelése a Köztársaság megalakulása után.........................74

2.6.2.3. Az AK Parti nemzetfelfogása...................................................................76

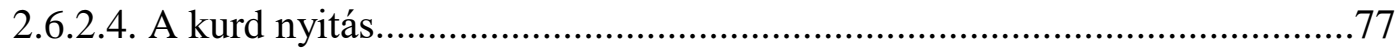

2.6.2.5. A török-kurd viszonyt terhelö problémák...............................................79

2.6.2.6. A kurd kérdés külpolitikai vetülete....................................................82

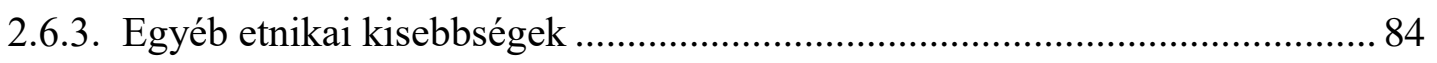

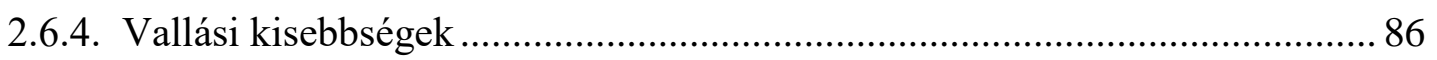

2.7. Az AK Parti megítélésének romlása, a látványos politikai feszültségek

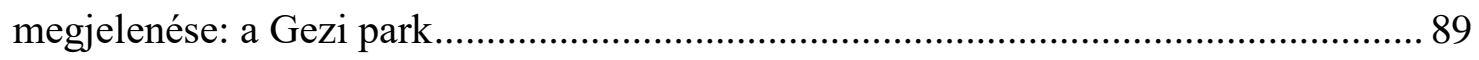

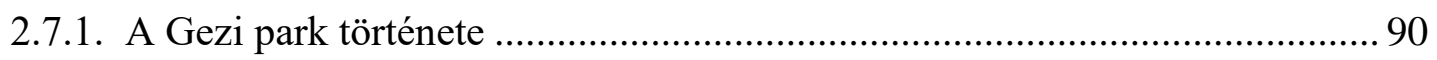

2.7.2. A Gezi park és környezetének átépítése .......................................................90

2.7.3. Tömeges fakivágással járó projektek Törökországban ................................92

2.7.4. A török civil és zöld mozgalmak.................................................................. 92

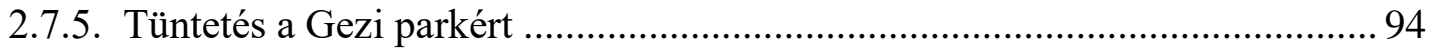

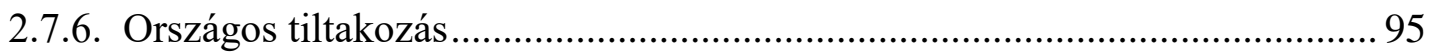

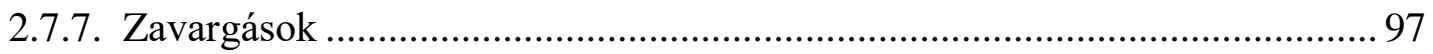

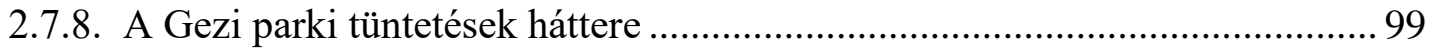

2.7.9. Miért maradt hatalmon az AK Parti-kormány?........................................... 100

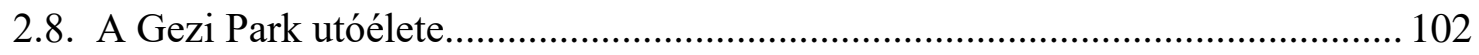




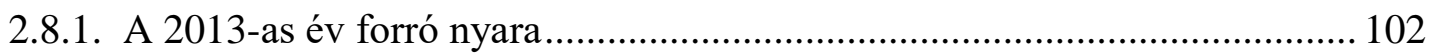

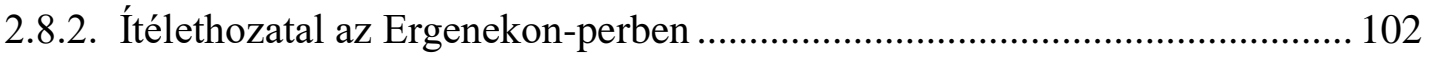

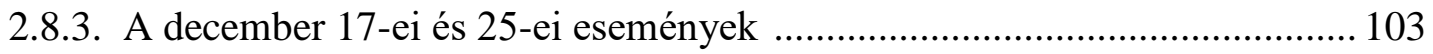

2.8.4. AK Parti-kormány kontra Gülen mozgalom ............................................... 104

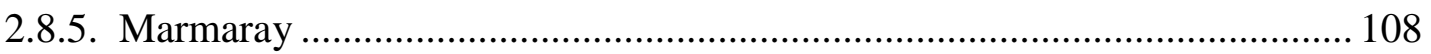

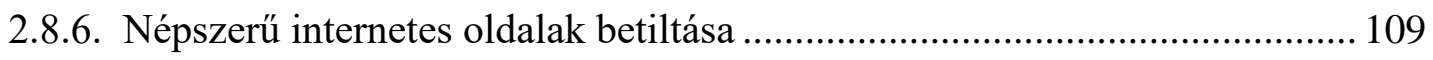

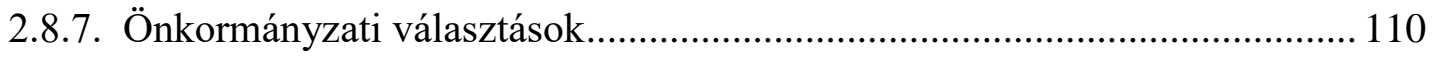

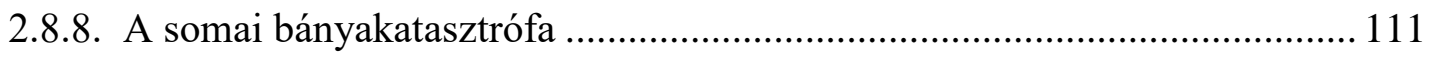

2.8.9. Az ISIS támadása a moszuli török konzulátus ellen ................................. 111

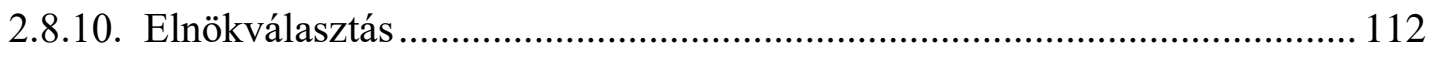

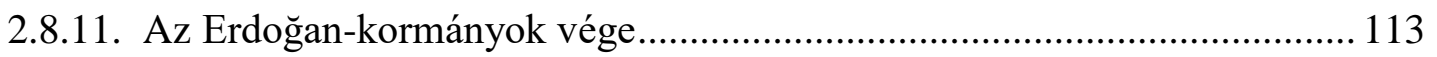

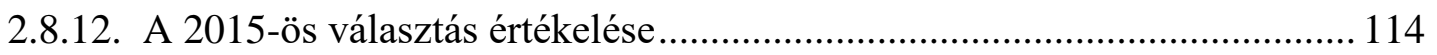

3. Fontosabb belpolitikai események Törökországban 2015 és 2018 között....................115

3.1. Az elnöki rendszerre való áttérés.............................................................116

3.2. Az Erdoğan-Gülen-párharc és a 2016. július 15-i sikertelen puccskísérlet......125

3.3. Törökország belső biztonsági helyzetének megrendülése.............................132

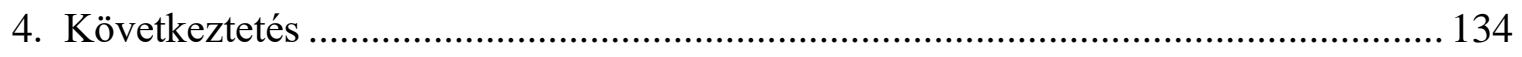

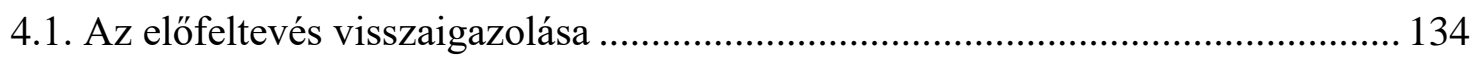

4.2. A demokrácia elmélete és a török valóság...................................................143

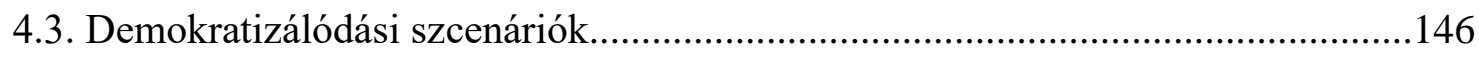

4.4. Az elméleti kutatatás további lehetséges irányának meghatározása ................... 148

4.5. Az elmélet gyakorlati haszna ............................................................. 151

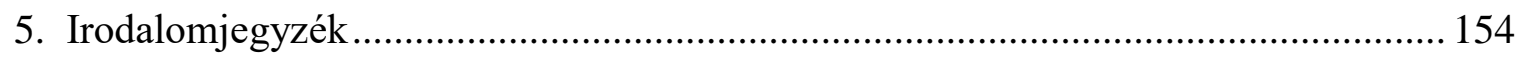




\section{Bevezetés}

A 2002. november 3-án rendezett törökországi nemzetgyülési választásokon a Recep Tayyip Erdoğan vezette mérsékelt iszlamistának vagy iszlamista gyökerünek tartott Igazságosság és Fejlődés Pártja (AK Parti ${ }^{1}$ ) a szavazatok 34,29\%-ával megszerezte a képviselői helyek kétharmadát. A jobbközép formáció az ezt követő négy voksoláson (2007, 2011, 2015 és 2018) is magabiztosan nyert, így egyedül kormányt alakítva esélyt kapott arra, hogy hosszabb távon is megvalósítsa politikai, gazdasági és társadalmi reformterveit. A számos külpolitikai kihívás és a belpolitikai válsághelyzet ellenére a vizsgált időszakban, azaz 2002 és 2018 között a kormány a helyén maradt: a kabinet támogatottsága nem, vagy alig csökkent a választásra jogosultak köreben. Sőt 2011-ben már a szavazatok 49,83\%-át adták az AK Partira, ezután a demokratizálás megtorpanása okán vesztett a népszerüségéből az AK Parti, de még 2015-ben és 2018-ban is, tizenhárom, illetve tizenhat év kormányzás után is 42\% közeli eredményt ért el a kormánypárt.

Az AK Parti „hosszú évtizedére” a gazdaság - bár egyre csökkenő ütemü - növekedése mellett a demokratikus intézményrendszer folyamatos változása volt jellemző, ami egyre inkább a hatalom centralizációjával járt együtt. Az egyéni és kollektív demokratikus jogok kiszélesítésével és népszavazással megerősített alkotmánymódosításokkal, illetve azzal, hogy 2014-től kezdve a nép választhatja meg a köztársasági elnököt, új keretet nyert a népképviseleti demokrácia. A sokrétű reformhagyományokból és az állam szekuláris jellegéből táplálkozó kormányzás ugyan nem számolta fel a társadalmi egyenlőtlenségek egy részét, mégis 2013-ig, a demokratizálási folyamat kezdődő válságáig és Recep Tayyip Erdoğan hatalomkoncentrációja megvalósulásáig szociális, gazdasági és kulturális átrendeződéssel járt. Kutatásom tárgya ezért a Török Köztársaság 2002 és 2018 közötti kormányai politikájának elemzése. Ezen a korszakhatáron belül két különböző arculatú időszakot érdemes elkülöníteni. Azt lehet mondani, míg 2002 és 2013 között a törökországi politikai folyamatok a demokratizálódás irányába mutattak, addig egy rövid válságos periódust követően ebben a tekintetben hanyatlás volt tapasztalható. A török állam és a politikai berendezkedés demokratizálódásában bekövetkezett negatív változásokat nem csupán a trendek elemzéséből állapíthatjuk meg, hanem azok objektív mérőszámokkal is jellemezhetőek. Sőt, ezen adat segítségével az is bemutatható, hogy Törökország esete szembe megy a globális folyamatokkal, a világ társadalmainak egyre demokratikusabbá válásával. A The Economist által alkalmazott

\footnotetext{
${ }^{1}$ Igazságosság és Fejlődés Pártját két féleképpen lehet rövidíteni: AKP és AK Parti. Az utóbbi a hivatalos, a választási irodánál és belügyminisztériumnál így bejegyzett rövídítés. Ezért a disszertációban ezt használom.
} 
módszer szerint is a fordulat 2013-ban állt be, mikor is az előző évi 5,76-ról 5,63-ra csökkent Törökország demokrácia indexe, ami azt követő években is meredek ereszkedést mutat, és 2018-ban már csupán 4,37, amivel Törökország -ezen besorolás szerint- a hibrid rezsimek alsó régiójába tornázta le magát. (THE ECONOMIST, 2019)

Törökország közeli múltjának vizsgálata az ország geopolitikai jelentőségén túl azért is fontos, mert az élénknek nevezhető magyar-török politikai, gazdasági és kulturális kapcsolatok ellenére aránylag kevés elemző munka jelent meg a témában.

Kutatásom szempontjából releváns áttekinteni a klasszikus demokrácia-modelleket, és ezeket egybevetni a törökországi politikai fejlődéssel. Így mindenképpen meg kell vizsgálnunk:

- a Török Köztársaság intézményrendszerét,

- a török népképviseleti szervek müködését,

- a török politikai pártok elveit és gyakorlatát,

- a civil társadalom helyét a török politikai életben.

Az euroatlanti integráció mellett következetesen kiálló török politikai elit - amely kisebb kitéröktől eltekintve nem ütött meg kritikus hangot az Európai Unióval (EU) kapcsolatban alapvető hivatkozási pontjai közé tartoznak az európai minták, ugyanakkor a politikusok többször élnek hazafias retorikával is. Ezért külön ki kell térni arra, hogy mi származik az Európából elterjedt politikai ideológiákból, - mint a liberalizmus, a konzervativizmus és a szociáldemokrácia -, illetve mi az, ami sajátosan török. Miután az AK Partit sokszor mérsékelt iszlamistaként írjuk le, szükséges lesz a török hagyományok között górcső alá venni a vallási értékek és a szekularizmus viszonyrendszerét. A török politikai hagyományok vizsgálata során az interdiszciplinaritás eszközeivel is élve érdemes végigkövetnünk mindazon időszakokat, amelyek nagyban hozzájárultak a török demokrácia ma ismert formájának kialakulásához. A legfontosabb vizsgálandó időszakok ebben a tekintetben a következőek: a modern Török Köztársaság kialakulása és az atatürki államszervezés - hangsúlyozva, hogy a 18. század végén, 19. század elején már megindultak az oszmán szultánok modernizációs törekvései -, a többpártrendszer megszületése az 1940-es években, a Demokrata Párt törekvései az 1950-es években, Turgut Özal miniszterelnöksége, az 1990-es évek, és végezetül a 2002-től napjainkig terjedő AK Parti uralmával jellemzett időszak, amely a tézis központi eleme. Természetesen a reformtörekvések mellett nem szabad megfeledkezni az azokat gátló eseményekről sem. A három katonai puccs után megerősödő, majd a politikai életből egyre inkább kiszoruló hadsereg 
szerepének leírása is megkerülhetetlen. A történelmi áttekintés arra is lehetőséget biztosít számunkra, hogy analizáljuk a 2000-es évek politikai változásainak mélységét.

Az események mellett azok alakítói, a tárgyalt tizenhat év legmeghatározóbb politikai szereplői, életútjuk és társadalomalakító szerepük is fontos munkám szempontjából. A politikatudomány vizsgálódási szempontjai között napjainkban - föleg a technikai-technológiai forradalomnak és a médiapártok megjelenésének is köszönhetően - egyre inkább előtérbe kerülnek a személyiségek mint a politika meghatározó aktorai, és figyelem irányul a politikaformálók pszichológiai jellemzőinek feltárására is. A személyiség így nem csupán egy korszak irányítójaként, markáns alakjaként tünik fel, de szinte tükörként szolgál a korra nézvést, amely „kitermelte” az adott vezetőt. Korszakunkat tekintve kétségtelenül a legmarkánsabb az értékelvü, ám autoriter kormányzási stílussal jellemezhető Recep Tayyip Erdoğan. Ugyanakkor fontos szerep jutott a vizsgált időszakban Abdullah Gülnek, aki az AK Parti politikusából lett köztársasági elnök, majd egy kissé kegyvesztett és a politikától visszavonult személy, valamint a külügyminiszterből miniszterelnökké avanzsáló, a muszlimok politikai szerepvállalásával elméleti síkon is sokat foglalkozó Ahmet Davutoğlu munkássága sem.

A 2002 és 2018 közötti török kormányok tevékenységei során négy alapvető téma beható elemzése elkerülhetetlen:

- az AK Parti demokratizálási törekvései,

- a török társadalom „demilitarizálása”,

- az etnikai és vallási kisebbségek egyéni és kollektív jogai, különös tekintettel a kurdokra,

- a 2013-tól felerősödő elégedetlenségi hullám és a demokratizálódási folyamat kormányzati kezelése, kérdőjelei,

- Erdoğan párton belüli riválisainak háttérbe szorítása, demokrácia gyengyülése és 2015ös puccskisérlet utáni események és a török politika helyzete

Az elemzés kiindulópontja a pártok politikai programja. Arra fogok törekedni, hogy bemutassam azt a demokráciaeszményt, ami az AK Partira jellemző, és megnézzem, hogy abból mit sikerült megvalósítani. A kormányprogram és annak realizálása tekintetében számos különbséget tudunk majd felfedezni az egymást követő három kabinet törekvései és gyakorlata között. (A demokratizálási folyamatnak azonban van két, egymással szorosan összefüggő előfeltétele is: a Török Köztársaság belső békéjének, erős demokráciájának megteremtése úgy, hogy ahhoz ne a katonaság szerepvállalásán keresztül vezessen az út.) A török haderő fokozatos 
háttérbe szorulását, illetve a kurdokkal való békés megegyezés folyamatát az elmélet gyakorlatba való átültetése elsődleges prekondícióinak tekintjük. Mindkét reform számottevő átalakulással, és sokak számára érdeksérelemmel járt, így az isztambuli Sétatér, a Gezi park fái kapcsán kirobbant tiltakozási hullámban megjelentek mindazok a követelések, melyeket az átalakulás vesztesei fogalmaztak meg. A kormány végső sikere vagy bukása tehát nem csak azon múlott, hogy milyen átmenetet képzelt el, és azt hogyan valósította meg, hanem azon is, hogy mennyire törekedett kompromisszumra az érintett társadalmi nagycsoportokkal.

A demokratizálási folyamat válsága és megakadása ellenére a szavazók egy jól behatárolható köre kitart Recep Tayyip Erdoğan köztársasági elnök és pártja mellett. AK Parti társadalmi beágyazottságának és támogatottságának megértése érdekében célszerü megvizsgálni, hogy az elmúlt évszázad demográfiai változásai miképpen determináltál a török kormánypárt szimpatizánsainak körét. Az I. világháború, -mint oly sok más tekintetben is-, komoly törést okozott a törökség körében. A világégés kezdetén még 11 millió muszlim lakossal bíró Anatólia népességében három millió iszlám hívő a harcok, a járványok és a nélkülözés miatt elpusztult. A térség keresztény lakosainak nagy része vagy meghalt a háborús cselekmények következtében, vagy a népességcserék folyton külföldön volt kénytelen életét folytatni. A köztársaság egypárti időszakában megindult a népesség gyors növekedése, 1950ben már 20 millió ember élt Törökországban. Hetven év alatt ez a szám megnégyszereződött, 2019-ben 82 millió fő vallhatja magát török állampolgárnak. (AKYOL, 2019) A demográfiai adatok leginkább a falusi népesség körében mutatták a legnagyobb változást. Nem szabad elfelejteni, hogy ennek a rurális közösségnek csupán a töredéke tudott írni és olvasni, hisz az első, 1927-ben végzett ezirányú felmérés szerint 89,5\%-os volt az írástudatlanság, mikor a legtöbb európai országban az már csak 20-30\% között mozgott. (YAKUT, 2016) A népességrobbanás együtt járt ennek az alacsonyan képzett népelemnek a városokba való áramlásával. Ök és a leszármazottaik teszik ki az AK Parti támogatói körének a gerincét. Ez a kevésbé iskolázott, ám már a városi életmód kényelméhez hozzászokott népréteg leginkább az infrastruktúra fejlesztését várja el a konzervatív értékek képviselete mellett az AK Partitól, és ezzel magyarázható, hogy az újabb és újabb átadó ünnepség lelkesítő beszédei arra sarkalja őket, hogy nyilvánvaló megélhetési nehézségeik ellenére továbbra is az AK Partit tüntessék ki bizalmukkal.

A dolgozat felépítése hủen követi a fenti gondolatmenetet. A problémafelvető bevezetést követő tárgyalási rész nyolc fejezetből áll. Az elsőben politikaelméleti kérdésekkel foglalkozok, beleértve a demokrácia fogalmát és a civil-katonai kapcsolatok elemzését, de kitérek a kemalista és az erdoğani szekularizmus felfogásra is. A második részben a történelmi 
áttekintés, míg a harmadikban a rendszer bemutatása következik. A fennmaradó öt fejezetben pedig a fent bemutatott módon a kormány törekvéseitől eljutok annak kritikájáig és az arra adott válaszokig. Végkövetkeztetésemben azon hipotézisemet szeretném visszaigazolni, miszerint az AK Parti-kormány stabilitását az adta, hogy reformjai során mindvégig ragaszkodott az ország demokratikus és szekuláris hagyományaihoz. A harmadik fejezet a 2015-től kezdődő és 2018as júniusi választásig bezárólag eltelt időszak főbb történéseivel foglalkozik.

Összegezve a fent leírtakat a harmadik évezred elején tapasztalható török demokrácia azért méltó arra, hogy vizsgálatom tárgyát képezze, mert ugyan társadalmi megosztottság jellemzi, és nem független a régió konfliktusaitól sem, ám a puccskísérletek és a 2013. évi elégedetlenségi hullám ellenére stabilnak tekinthetjük és valószínüsíthetőleg az állam egyedi karaktere tartósnak bizonyul.

\subsection{A disszertációval kapcsolatban áttekintendő szakirodalom}

A török demokráciáról, demokratikus átalakulásról és az AK Parti kormányairól tengernyi szakirodalom áll rendelkezésre. Nemzetközi szinten is rengeteg publikáció született az utóbbi másfél évtizedben, s török nyelvü források is nagy számban foglalkoztak a törökországi átalakulásokkal. Ugyanakkor magyar nyelven viszonylag kevés mü jelent meg a témában. Flesch István maga is említést tesz arról az Atatürkről szóló könyvében, hogy a magyar tudóstársadalom adóssága a modern Törökország társadalmi-politikai helyzetének alapos elemzése. (FLESCH, 2002) Nem érdektelen az a momentum sem, hogy Kerekesházy József 1943-ban Atatürkről írott munkáját a Terebess kiadó 2000-ben újfent megjelentette, bizonyítva ezzel azt is, hogy még a világtörténelmi jelentőségű államalapítóról is alig születtek könyvek Magyarországon.

Ha pedig nem Atatürkről, hanem Erdoğanról vagy a török közelmúltról keresünk szakirodalmat, akkor csak néhány rövidebb tanulmányt találunk csupán, vaskos monográfia nem jelent meg a török közelmúlt eseményeiről. A magyar tanulmányok jelentős része inkább az AK Parti külpolitikájával foglalkozik, (N. RÓZSA, 2015) annak elsősorban közel-keleti kapcsolataival. (BALOGH-N. RÓZSA-RADA-SZALAI, 2013) A belpolitika sokkal kevésbé jelenik meg, egyedül a 2011-2012 közötti időszakra vonatkoztatva, amikor a „török modellről” írnak. (CSICSMAN-N. RÓZSA, 2013) A modell részletes tárgyalása, bemutatása magyar nyelven viszont nem történt meg.

Kiemelendő továbbá Szigetvári Tamás munkássága, aki tanulmányaiban főleg a török gazdaság helyzetével foglalkozott, az országban zajló belpolitikai folyamatok értékelése nála 
mellékes szerepet kapott. (SZIGETVÁRI, 2013) Disszertációm egyik kimondott célja ezen hiátus felszámolása. Azt szeretném, hogy dolgozatom vitaindítóként is szolgáljon, kövesse azt megannyi munka magyar nyelven, s Törökország közelmúltja ne legyen fehér folt a magyar társadalomtudomány számára.

A kifejezetten török belpolitikával is foglalkozó magyar nyelven írt könyvek és tanulmányok legtöbbször pozitívan értékelik az AK Parti kormányai idején történt eseményeket. (FLESCH, 2007) Egeresi Zoltán a 2011-es választásról szóló tanulmányában kiemeli, hogy az ország jelentős gazdasági fejlődésen ment keresztül, amellyel sikerült megszereznie a kormánynak a választók jelentős részének a támogatását. (EGERESI, 2010) Egy későbbi munkájában megemlíti, hogy az AK Parti reformjai egy széles középosztály kialakulásának kedveztek. (EGERESI, 2011) Máshol pedig amellett érvel, hogy a katonai puccsok ellenére Törökországban 1950 óta néhány rövidebb időszakot leszámítva demokrácia van, egy sokszereplős pártrendszerrel, amelyben megtalálhatóak az Európában is ismert pártcsaládok. (EGERESI, 2013) Ugyanakkor Egeresi sem foglalkozik részletesen a demokrácia kérdésével, annak törökországi formájának értékelésével. Még a hadsereg és a civil kormány viszonyát boncolgató tanulmányában is csak kevés teret szentel az elméletnek, s a demokratizálódással mint a háttérben meghúzódó folyamattal nem foglalkozik, valamint a hadsereg és az AK Parti viszonyát hatalompolitikai játékként írja le. (EGERESI, 2013)

$\mathrm{Az}$ angol nyelvü szakirodalomban a legnagyobb törésvonalat az AK Parti megítélése jelenti, amely a szekularizmus és az iszlamizmus, és a hatalomgyakorlás kérdését helyezi legtöbbször a középpontba. Ki kell emelni, hogy e könyvek szerzőinek jelentős része török társadalomtudós.

Közülük az egyik legismertebb kutató, Hakan Yavuz egyik alapvető munkájában abból a dilemmából indul ki, hogy az AK Parti iszlamista párt-e valójában. Yavuz okfejtése végén arra jut, hogy az AK Parti iszlamista, és négy komoly kihívásra kell választ találni. Ezek a társadalmi részvétel, a gazdasági fejlődés, a belbiztonság szavatolása és kurd kérdés rendezése, azaz a kurd nyitás. (YAVUZ, 2009) Miután megvizsgálja a politikai formáció eredetét és történetét, arra a következtetésre jut, hogy témám szempontjából kulcskérdés az identitás, és főleg az, hogy a demokratikus kormányzat, a politikai elitek önazonosság-tudata ne essen messze a tömegekétől. Yavuz érvelése szerint ez különösképpen a kurd kérdés megoldása szempontjából bír komoly jelentőséggel. Egy tanulmánykötet bevezetőjében pedig azt is felveti, hogy kialakult egy „új burzsoázia” Törökországban, ami a kormánypárt támogatóiból és a 2002-es kormányváltás haszonélvezőiből áll. (YAVUZ, 2006) Ez pedig annak a veszélyét hordozza magában, hogy ez az új társadalmi réteg elszakad a néptömegektől, és két különböző identitás 
jelenhet meg: egy elitista és egy népi konzervativizmus. A társadalmi beágyazottsághoz kapcsolódik az a kérdés, vajon a pártok formálják-e a tömegek preferenciáit, alakítják a napirendet, amelyre a társadalmi rétegek rezonálnak, vagy a pártok képezik le a társadalomban meglévő törésvonalakat és sikerrel mobilizálnak politikai programjuk mentén. Szintén angol nyelven ír Müge Aknur, aki a demokratikus konszolidációról szóló könyvében azt vizsgálja, hogy ugyan a demokratikus átmenet már az 1950-es évek elején megkezdődött, de a török berendezkedés még mindig nem érte el a konszolidált demokrácia szintjét. (AKNUR, 2012) Az elmúlt hatvan év a demokratikus politikákban folyamatos szakadásokat hozott. A demokratikus konszolidáció elhúzódása mögött a szerző több tényezőt vél felfedezni. Szerinte ebben közrejátszottak a politikai pártok, a civil társadalom gyengesége, Törökország lassú fejlődése, és végül, de nem utolsó sorban a civil-katonai kapcsolatok, a hadsereg túlhatalma és állandó puccsai. Aknur külső tényezőket is felsorol, így például a Szovjetunió közelségét, ugyanakkor az Európai Unióhoz történő csatlakozást pozitív színben festi le, ami jelentős mértékben hozzájárul az országban a stabil demokrácia megteremtéséhez. A törökországi demokrácia kérdéséről angolul és törökül is publikáló neves társadalomtudós, Fuat Keyman müveiben (KEYMAN, 2006) elsősorban a modernitás és demokrácia témakörével foglalkozik. A 2008ben megjelent, Remaking Turkey: Globalization, Alternative Modernities and Democracy címü müvében amellett érvel, hogy 2001 után világszerte bekövetkezett egy általános instabilitás, terrortámadásokkal, háborúkkal, és az iszlámot sokszor a terrorizmussal azonosították, azonban Törökországban épp azt láthatjuk, hogy egy muszlim országban megfér a vallás a szekuláris modernitással, müködik a virágzó piacgazdaság és a liberális demokrácia. (KEYMAN, 2008)

Keyman és Koyuncu emellett kifejti, hogy egy paradoxon is jellemző az AK Parti komplex politikai céljaira: amellett, hogy a gazdaság liberalizálódik és elterjed egy egyfajta racionálisbürokratikus szemlélet. Azt is mondhatnánk, hogy egyfajta kettős identitás jellemzi a törököket: Keyman szerint a liberalizálódó gazdaság mellett a politikát gyakran nem a racionális beszédmód, hanem az identitáspolitika, egyfajta tradicionalizmus, a „visszatérés az autenticitáshoz" jellemzi.

Ergun Özbudun és Ömer Faruk Gençkaya a törökországi demokratizálódásról és az ahhoz kapcsolódó alkotmányokról szóló müvükben megállapítják, hogy a török alkotmányokat (1924, 1961, 1982) sosem a török társadalom különböző rétegeit széles körben képviselö, általánosan elfogadott Alkotmányozó Nemzetgyülés írta. (ÖZBUDUN-GENCKAYA, 2009) Alapvetően felülről kitalált és alkalmazott alkotmányok voltak érvényben, nem pedig hosszú tárgyalásos folyamat eredményeként megszülető alaptörvények, amelyekben többféle érdek érvényesült volna. Véleményük szerint ezeknek az alkotmányoknak következésképp gyenge politikai 
legitimációja volt. A szerzőpáros szerint az európai uniós csatlakozás új fordulatot jelent ebben a helyzetben. A koppenhágai kritériumok teljesítésére tett erőfeszítések, az elfogadott harmonizációs csomagok jelentős lépést jelentettek az alkotmányos reformok terén. A folyamatban megkülönböztetett szerep jutott az AK Partinak, amely megfelelően reagált a társadalom részéről megfogalmazott demokratikusabb és liberálisabb politikai rendszer iránti óhajra. Tehát a politikai rendszer európanizációja, a mintakövetés a belső strukturális legitimáció hiányosságait kompenzáló tényező volt, és egyben a demokratizálás eszközeként is szolgált. A török politikában a meg nem gyökerezö, nem teljesen konszolidálódott demokrácia keleti kiadását véli felfedezni és a reformok beágyazottságának hiányát, a politikai voluntarizmust, az egyszemélyes vezetés hagyományát és az alapvetően konzervatív társadalmi berendezkedést okolja a felemás demokratikus átmenetért. Joggal merül tehát fel a kérdés, hogy politikai karakterét és kulturális hovatartozását tekintve hova tart(ozik) Törökország?

A disszertációhoz egyrészt rendelkezésünkre áll a török és angol nyelvű szakirodalom, amit ki tudunk egészíteni néhány magyar nyelvü művel is. Emellett a kor közelsége miatt szinte korlátlan számban lelhetjük fel az elsődleges forrásokat is. Ezen kategóriába soroljuk egyrészt a választási rendszer, másrészt a törvényhozás dokumentációját. A kettő találkozásaként pedig rendelkezésünkre áll a 2010-es alkotmánymódosítás is, amit egy referendum erősített meg. Szintén e források között tartjuk számon a politikusok beszédeit, egyes elemző jellegü újságcikkeket és egyéb reflektív elemzéseket, közvélemény-kutatásokat, melyek a török közvéleményre vonatkozóan tartalmaznak eredeti információkat. Módszertani szempontból tartalomelemzést fogunk végezni, azaz rendszerezetten tekintjük át mind a szakirodalom megállapításait, mind az autentikus dokumentumokból levonható következtetéseket. A keletkező alapadatok többsége egyrészt már átesett egyfajta tudományos szürőn (szakirodalom), másrészt értelmezésre szorul (elsődleges források). Az utóbbi csoportot kellő forráskritikával kell szemlélnünk, de ez vonatkozhat a szakirodalom egy részére, ami esetenként lehet részrehajló.

A kutatást egyéni adatgyüjtésre és adatfeldolgozásra szeretném építeni nyelvtudásom révén. A magyar szakirodalom szükössége miatt angol források mellett elsősorban török forrásokat használok a doktori disszertáció elkészítéséhez. Ezzel a témával foglalkozó könyveket, a legfontosabb nyomtatott - és online média híradásait és különböző tanulmányokat használok. 


\subsection{Hipotézisalkotás}

Disszertációmban az alábbi fő hipotézisek alátámasztására fogok törekedni:

- A 2002 és 2013 közötti időszakban az AK Parti kormányok alatt Törökországban demokratizálódási folyamat zajlott.

- A 2013 és 2018 közötti időszakban az AK Parti kormányok alatt Törökországban demokratizálódási folyamat gyengült.

- Az AK Parti a szekuláris államberendezkedés híve, s reformjai egy újfajta, a kemalistáktól eltérő szekularizmust valósítottak meg.

Fő hipotéziseim mellett néhány egyedi és általános részhipotézist is meg kell fogalmaznom:

- Törökország belső békéjének és stabilitásának egyik előfeltétele a hadsereg erejének megőrzése mellett annak politikából való kivonása.

- Törökország belső békéjének és stabilitásának másik előfeltétele a kisebbségek, elsősorban a kurdok helyzetének rendezése.

- A kormányok stabilitásának politikai és gazdasági előfeltételeit képezik a gazdasági és infrastrukturális fejlesztések, a regionális különbségek felszámolása, valamint a népjóléti intézkedések.

A hipotézis alátámasztása érdekében annak alapos elméleti bemutatására és elemzésére van szükség. Miután a mai Török Köztársaság demokratikus hagyományai egészen az 1770-es évekig nyúlnak vissza, nagyívű történelmi összefüggéseket kell átlátnunk, és hangsúlyt kell fektetnünk a történelmi szemléletre. A disszertáció interdiszciplináris jellegét erősíti az is, hogy nem csupán a hipotézisalkotásunk során kívánok a történelemkutatás eszközeivel élni, hanem akkor is, amikor a kormánypárt ideológiai gyökereit keresem.

Nem felejtkezhetünk meg a szociológiai vizsgálódásról sem, hiszen - ahogy azt már Yavuz müvei kapcsán korábban említettük - új elit született, átrétegződött a török társadalom, amit annak beható analízise nélkül nem tudunk megérteni. Egy olyan országban, ahol rövid idő leforgása alatt három államcsíny is volt, illetve évtizedek óta kell együtt élnie a polgároknak a terrorizmus rémével, természetes, hogy egyfajta harci pszichózis lesz úrrá, ha felbomlik a rend és fellép egy belső válsághelyzet. A lélektan ennek a különös tudatállapotnak a megértésében is hasznunkra válik. Doktori disszertációm témája a Török Köztársaság 2002 és 2018 közötti 
kormányai müködésének elemzésére terjed ki, ugyanakkor szükség van az előzmények vizsgálatára is ugyanúgy, mint a 2014-ben történt változások részletezésére.

Az előzmények vizsgálatára egyrészt azért van szükség, mert hipotézisünk szerint a kormányzat stabilitását a demokratikus- és reformhagyományok tiszteletben tartása és a szekuláris államrend megtartásának kettős törekvése eredményezi. Emellett nem elhanyagolható, hogy a kormányzó Igazságosság és Fejlődés Pártja számos ideológiai előképpel bír, nevezetesen politikai alapvetése egyaránt támaszkodik mind az 1950-es évek Demokrata Pártjának a vallásos néptömegek felé nyitó politikájára, mind Turgut Özal, mind pedig Necmettin Erbakan kormányfők müködésére. Az utóbbihoz köthető Milli Görüş ideológia pedig - bár ma már más párt képviseli - még mindig hat a török kormány politikaformálására.

A 2014-es év változásaira és az új, Ahmet Davutoğlu által vezetett kabinetre azért szükséges kitérni, mert látnunk kell, mi lett az Erdoğan-kormányok müködésének hatása, illetve érdemes áttekinteni azt is, mit változott a rendszer azzal, hogy egy általános választáson, a nép által választott elnök komoly súllyal vesz részt a politikai életben. Felmerül a kérdés, hogy ez a személycsere mennyiben módosítja azt az alkotmányjogi helyzetet, az hogyan hat a török parlamentáris demokrácia minőségére.

A kutatás a térben leginkább a törökországi belpolitikai eseményekre terjed ki, azaz nem célunk a „török modellt” egybevetni a térség más országaiban lévőkkel, illetve a törökországi eseményeket nem vetjük össze - a meglévő hasonlóságok ellenére sem - az arab tavasz állomásaival. Mindez nem jelenti azt, hogy nem kellene a török külpolitika néhány aspektusát górcső alá venni. Ez különösképpen igaz például az Észak-Iraki Kurd Autonóm Területtel kapcsolatos politizálásra, hiszen az nagyban meghatározza a belföldi török-kurd közeledést.

A demokratizáció mint makrokeret jelenik meg, míg a katonai szerepvállalók és a politika egyben az intézményi változás fokmérői is. A kisebbségek helyzetének, státuszának és jogainak változása az emberi jogi, kisebbségi és identitáspolitikai aspektus bemutatására ad lehetőséget. A katonaság-civil szféra kapcsolata nem csupán szakpolitikai, bürokratikus kérdés, hiszen a hadsereg civil kontroll alá vonása a demokratikus jogállam kiépítésének egyik fontos próbája, másrészt, értékválasztás, az identitáspolitika része is. 


\section{A demokrácia és szekularizmus elméleti kerete}

A demokrácia fogalmáról és hosszú múltjáról szintén tengernyi szakirodalom áll rendelkezésre. Jelen müben az elméleti keret megalapozásának érdekében rövid történelmi áttekintés után a demokráciáról kialakult koncepciókat veszem górcső alá. Ezzel rá kívánok mutatni arra, hogy a demokrácia fogalma az elmúlt évszázadok folyamán sokat változott, és csak az utóbbi százötven évben kapott pozitív megítélést.

Magának a fogalomnak a meghatározása sem egyszerü. Ahogy Giovanni Sartori demokráciáról írt könyvében megjegyzi, a demokrácia szónak - ami szó szerint néphatalmat jelent - az értelmezése is problémákat vet fel. A görög eredetủ démosz szót már az ókorban is többféle kifejezéshez kapcsolták. Jelentette a polgárok összességét, a sokaságot, a többséget, de még a csőcseléket is érthették alatta. (SARTORI, 1999, 20) A mai fogalmak szerint a nép lehet:

- $\quad$ szó szerint mindenki;

- nagyobb létszám, a sokaság;

- a köznép, az alsóbb néposztályok, a proletariátus;

- szerves és oszthatatlan totalitás,

- a többségi elv korlátozás nélküli alkalmazásával kijelölt rész;

- a többségi elv korlátozott alkalmazásával kijelölt rész. (SARTORI, 1999, 21)

A szerző végül amellett foglal állást, hogy az utolsó értelmezést érdemes a demokrácia értelmezések közül a „néppel” azonosítani.

Mint említettem, a demokrácia fogalma rengeteg változáson ment keresztül. Az ókorban alapvetően államformaként írták le, s a nagy görög filozófusok szemében inkább negatív megítélés alá esett és komoly kritikák érték. Az egyik első, a definícióval mélyebben foglalkozó filozófus, Platón kifejezetten rossznak tartotta, mivel azt a csőcselék uralmával azonosította. Egy őt követő filozófus, Arisztotelész a demokráciát a kevesek uralmával, az oligarchiával állította szembe. (ÖZCAN, 2009, 125-148) A demokrácia, ami a korszakban lehetővé tette, hogy a népgyülésen résztvevők elmondhassák a véleményüket a városállamot érintő kérdésekről és szavazzanak a vezetők döntéseinek jóváhagyásáról, valamint a köztisztviselők kinevezéséröl csak kevés görög városban létezett. (NÉMETH, 1996) Az ókor viharait a 
városállamokra épített demokrácia nem is élte túl, az azokat meghódító birodalmak nem a hatalomgyakorlás ezen módja szerint müködtek.

A népből eredeztethető hatalom gondolata újra majd csak a 18-19. században, a nagy francia filozófus, Jean-Jacques Rousseau írásaiban és kortárs amerikai államférfiak műveiben jelent meg. Rousseau elképzelése szerint a nép a hatalom forrása, a hatalom gyakorlása az általános akaratnak megfelelően és a nép közvetlen hatalomgyakorlásával lenne lehetséges. (HAKYEMEZ, 2003, 69-72) Ekkor alapvetően a köztársaság fogalmával kapcsolták össze a népképviseletet, Amerikában viszont kifejezetten ellentétet láttak a demokrácia és a köztársaság között. Az elöbbi a korszakban a polgárok közvetlen részvételét jelentette a hatalom gyakorlásában, míg az utóbbi a választott képviselők útján történő döntéshozást és irányítást. (HUDECZ, 2007, 20) Immanuel Kant az amerikai Madisonhoz hasonlóan ugyancsak ellentétet látott a köztársaság és a demokrácia között, mivel szerinte a demokratikus uralkodási forma despotikus. (SARTORI, 1999, 122-123)

A 19. század második felében elkezdődött a köztársaság és a demokrácia fogalmának összeegyeztetése, amely a demokrácia megítélésén is javított. John Stuart Mill a képviseleti demokrácia fogalmában tette ezt meg, ugyanis szerinte a választott képviselők útján történő hatalomgyakorlást is lehet demokráciának nevezni, hogy ha minden állampolgár egyenlő mértékben képviseltetik. Millnél tehát a demokrácia az egyenlőségre épül. (HUDECZ, 2007, 21)

A demokrácia elemzésének, leírásának modernebb nézőpontrendszer szerinti megadása Joseph A. Schumpeter nevéhez füződik. Ő volt az, aki a procedurális megközelítés alapjait rakta le. Véleménye szerint a demokráciát mint politikai intézményrendszert kell vizsgálni, ahol a vezetők a mások szavazataiért folytatott versengés útján kerülnek hatalomra.

Az ő megközelítését Martin Seymour Lipset fejlesztette tovább. (SEYMOUR LIPSET, 1960) Lipset megközelítésének középpontjában a versengés feltételeinek megteremtése és annak törvények által szavatolt biztosítása állt. Nem mellesleg a verseny feltételei között külön hangsúlyozta a hatalmon lévő politikai elit szerepét és az alternatív csoportok hatalom megszerzésére való törekvését, amely természetesen legitim módon történik. Lipset értelmezésében újdonságnak számított a szociológia megjelenése. Ő a demokrácia feltételeinek és müködésének megvalósulásához nélkülözhetetlennek tartotta az ország gazdasági fejlettségének előrehaladott állapotát. Ezalatt a városiasodás fokát, a népesség magasabb müveltségét és az iparosodottságot értette, miközben hangsúlyozta a legitimitás fontosságát mint a politikai rendszer társadalmi és egyéb konfliktusok sikeres kezelésének képességét. 
Az 1960-as évektől kezdve Lipset értelmezése és módszertana jelentős hatással volt a későbbi demokráciával foglalkozó gondolkodókra. A dél-európai államokban, majd pedig a Kelet-Európában zajló demokratizálódás leírására és értelmezésére megjelent a tranzitológia, amely azt a folyamatot volt hivatott leírni, hogy hogyan, milyen feltételek mentén alakulnak demokráciákká a diktatórikus rendszerek, mely társadalmi és intézményi tényezők segítik elő, esetleg hátráltatják ezt a folyamatot.

A tranzitológia Latin-Amerika és Kelet-Európa demokratizálódásának példáján - elég itt Stephan Linz, Karl Schmitter, vagy a magyar Ágh Attila és Bozóki András kutatásaira utalni a demokrácia meggyökerezésével foglalkozott. Emellett, a demokrácia irreverzibilitása is fontos kérdésként merül fel: melyek azok a szükséges feltételek, amelyek garantálják, hogy a demokrácia ne legyen visszafordítható? Vagyis a puccsok, hatalomátvételek, esetleges alkotmánymódosítások ne az autoriter hagyományok feléledésével járjanak.

Az 1990-es évekre a demokrácia fogalma erősen átpolitizálódott, amelyben jelentős szerepet játszott az Egyesült Államok és az Európai Unió. (HUDECZ, 2007, 29) Ugyan ez nem a két blokkra oszlott világrend végének újdonsága volt, hiszen már korábban több amerikai elnök beemelte a demokrácia védelmét és terjesztésének szükségességét a politikai programjába, azonban az 1990-es évektől kezdve egyre komolyabb morális tényezővé vált a demokrácia az államok külpolitikájában és más államok megítélésében. A demokrácia fogalma és az emberi jogok védelme összemosódott egymással, amelyet Larry Diamond liberális demokráciának nevezett. Diamond értelmezésben a demokrácia a kisebbségi jogok védelmét, a jogállamiságot, a független bíróságokat, az alapvető emberi jogok védelmét és a civil társadalom tiszteletben tartását jelenti. Ezzel ellentétes oldalon az illiberális demokrácia jelenik meg, amelyben az államhatalom használata nem foglalkozik az emberi jogokkal.

A morális alapvetés, az értékelvü külpolitikai hitvallás mellett szerepet játszott a demokrácia exportjához kapcsolódó azon biztonsági megfontolás, amely szerint a demokráciák nem harcolnak egymás ellen. A demokrácia exportja tehát a nemzetbiztonság kulcsa.

Hudecz Gergely ennek eredményét az alábbi módon jellemzi: „A demokrácia fenti, egyre tágabb, politikusabb, képlékenyebb és értékkel telítettebb megfogalmazása mára ahhoz vezetett, hogy a demokrácia értelmezése egyre inkább az adott politikai kontextustól és kulturális közegtől függ, mintsem objektív tudományos ismérvektől. Különösen igaz ez akkor, ha egy adott hatalom (jelenleg az Egyesült Államok) próbálja saját liberális demokrácia értelmezése alapján átformálni a világot. Ilyenkor merül fel a kérdés, hogy vajon a demokrácia fogalma mennyiben használható és intézményrendszerre mennyire alkalmazható más politikai és kulturális közegben.” (HUDECZ, 2007, 30) 
Ehhez kapcsolódóan, a kulturális beágyazottsághoz kötődően szót kell ejteni arról a vitáról, amely a demokrácia és az iszlám összeegyeztethetőségéről szól. Az értékalapú demokráciafelfogások sem egységesek. Hudecz Gergely két nagy csoportot különböztet meg: az egyik Francis Fukuyamához, a másik Samuel P. Huntingtonhoz kötődik. Fukuyama univerzális, optimista-idealista alapvetése a történelem végéről a hidegháború lezártával a liberális demokrácia globális beköszöntét jósolta, amely alapvetően egy nagyobb konfliktusoktól mentes világot szül.

Fukuyamára válaszul, 1993-ban Samuel Huntington egy olyan multipoláris világot vízionált, amelyben az identitások feléledése és a kulturális/vallási civilizációk mint alapvető rendezőelvek a jellemzőek. A nyolc civilizáció harmonikus együttélése helyett a nyugati és iszlám civilizációk összeütköznek. Huntington a török államot egyfajta átmeneti entitásként látta, amely „elszakadó állam”: az iszlámból a nyugati civilizációba tart. Ebből a szempontból érdekes, hogy a gyakran elhangzó vád, miszerint Huntington egyfajta kulturális determizmusként látta a történelmet, épp a török civilizáció-váltás cáfolná meg. Az európai integrációhoz való csatlakozás a nyugati civilizációhoz való kapcsolódást jelenti, amely azonban felveti, hogy mennyiben választás kérdése a muszlim cilivilzációtól való eltávolodás, mennyire kompatibilis a két kultúrkörhoz való egyszerre tartozás.

Az eddig bemutatott demokrácia fogalmak és értelmezések alapján látható, hogy a török demokrácia értelmezéséhez széles fogalmi és módszertani eszköztár áll rendelkezésre. Az értekezésben Lipset értelmezését és módszertanát fogjuk használni.

Mint említettük, Lipset eredményes munkássága nagy szerepet játszott abban, hogy az addig sokszor homályos és ellentmondásokkal terhelt demokrácia felfogást egy sokkal jobban használható, módszertanilag sokkal kevésbé kifogásolható értelmezési keretbe helyezze. Ezt kívánjuk jelen mü kiindulópontjává tenni, s azt bizonyítani, hogy az AK Parti kormányzása alatt, a párt által erősen támogatott politikai folyamatok - amelyek hozzájárultak az intézményrendszer átalakulásához, a gazdaság ugrásszerü fejlődéséhez és következésképpen addig soha nem látott társadalmi változásokat is elindítottak - elvezettek egy demokratikusabb Törökországhoz.

A demokrácia meghonosodásának több évtizedes folyamata nem választható el az európai uniós csatlakozás párhuzamosan folyó eseményeitől sem. A hidegháború kontextusában az europeanizáció-demokratizáció különösen a portugál, spanyol és görög diktatórikus rezsimek bukása után fonódott össze, hiszen az EGK mediterrán bővítései egyben a nyugati demokráciák visszavezetését jelentették az európai családba. A 2007-es bolgár és román, valamint a 2013-as horvát bővítés is egyfajta redemokratizációs vagy konszolidációs bővítés volt, amely mögött 
nem csupán a gazdasági integráció, hanem ugyanannyira a politikai egységesítés logikájának szükségessége bújt meg. A török ,nyugatosodás” olyan szempontból felemás, hogy az 1952es török NATO-csatlakozás a török állam helyét egyértelműen a nyugati érdekszférában jelölte ki. Az Egyesült Államok vezette blokkhoz tartozás azonban nem jelentett valamiféle europeanizálódást, például kulturális vagy gazdasági értelelemben, mivel a tömbhöz tartozás csupán a biztonságpolitikai kooperációra korlátozódott, nem szivárgott le a török kulturális mintákba, a mindennapokba.

Basak Alpan az európeanizáció három modelljét különbözteti meg. Szerinte az európaizáció egyenesen „hegemóniai harc” (hegemonic struggle), amelyben az európaizáció diskurzusa formálja a török politikai beszédmódot, politikát. Alpan szakít a fentről lefelé tartó (top down) és „természetszerüleg asszimmetrikus” (inherently asymmetrical) elemzéssel és helyette egy olyan vizsgálódást tart célravezetőbbnek, amely „folytonos, nem fix és vitatott folyamat, amely a politikai küzdelmen alapul”. (ALPAN, 2011, 5) Ez azt jelenti, hogy az EGKcsatlakozás iránti vágy valamiféle lehetőség kihasználása, költség-hasznon elemzés, racionális választás semmint feltétlen értékelkötelezettség. A török geostratégiai pozíció, a katonai potenciál és a fontos regionális középhatalmi szerep kevésbé mutat egyértelmü aláfölérendelési viszonyt az EU-csatlakozás viszonylatában, vagyis, a török politika nagyobb zsarolási potenciállal rendelkezik, alternatívaként kelet felé fordulhat, ha a csatlakozás befagy vagy a belpolitika dinamikája úgy diktálja.

Ehhez az elméleti megközelítéshez hasonlóan erősen politikai, hatalomtechnikai fogalomként használja és a költség -hatékonyság szempontjából értelmezi M. Ugur és D. Yankaya is az integrációhoz való csatlakozást. A szerzők ,politikai vállalkozásnak” (political entrepreneurship) nevezik azt a folyamatot, amelyben az EU kondicionalitás utat nyitott a politikai reformok számára azáltal, hogy a vitatott reformok politikai költségét csökkentette. Hozzá kell tennünk, hogy ily módon az EU csatlakozás feltételeinek való megfelelés egyben külső legitimációs súlyt is adott a reformoknak. Solantin is hasonlóan vélekedik, aki az EU erős ösztönzőinek tulajdonítja a demokratikus változásokat, hangsúlyozza, hogy a változások nehezebbek lettek volna az EU nélkül. Arra is kitér, hogy az alkotmányos reformok a inherens belpolititikai mozgások következményei, nem vezethetőek le mintegy külső „,ingerekre” adott válaszokból, valamint hangsúlyozza, hogy az europeanizáció és a demokratikus átalakulás szorosan összefügg.

Másfelől, az Unió tehát kétféle legimitációs technika alkalmazásának is teret enged: egyrészt, a belső, reformok keresztülvitelekor mint külső hivatkozási alap szerepel, másrészt, a belső konfliktusok alkalmával instrumentális az ellenfelek leszerelésekor. Megfigyelhetjük, 
hogy 1999 óta komoly lépések történtek, hogy az alkotmányt Európa-kompatibilissé tegyék, de a teljes képhez az is hozzá tartozik, hogy az AK Parti az uniós integráció jelszavát is fel tudta használni, vagyis ellenfelei ellen bevetette az uniós kártyát.

A török eset különleges, hisz 1999 óta a kinn is vagyok, benn is vagyok forgatókönyvét látjuk megvalósulni. Az unióhoz való közeledés, majd a ciklikus elhidegülések, visszaesések kérdésessé teszik, hogy mennyire konszolidálódott a török demokrácia, a csatlakozás mennyiben értékválasztás vagy csupán materiális megfontoláson alapuló politika. A török esetben a gazdasági-materiális megfontolások egyaránt jelen vannak, a kérdés inkább az, hogy az EU csatlakozás mennyire a politikai mobilizáció és milyen mértékben az identitás, politikai kultúra változásának mércéje.

Az unió mint nem szüken vett, merev intézményi keretként és elvárásrendszerként, hanem azon túlmutató kulturális közösségként is értelmezést nyert. Törökország mint muszlim ország, amely két kontinens határán helyezkedik el, hagyományainál fogva és kettős kötődését tekintve is problematikusnak tünt a bővítést ellenzők számára.

A koppenhágai kritériumrendszer a politikai, gazdasági és az acquis megfelelésének hármas csomagjában nem tartalmaz kulturális-vallási előfeltételeket, mégis gyakran ezen „soft”, nem kvantifikálható dimenzió kerül elő, mint az európai-török inkompatibilitás melletti érv.

Özer tárgyalja, hogy a csatlakozási tárgyalások befagyása, az EU elfordulása a 80-as évek végén -majd a 2000-es évek elején is- a törökök számára mennyire fontos volt, milyen mély pszichológiai jelentőséggel bírt. Özer a fair eljárás (fair treatment) az elismerés és elfogadás kifejezéseket használja, utalva arra, hogy a történelmileg korábban ellenfélként müködő Európa barátságtalan gesztusa identitás problémákat okozott, pedig a csatlakozás, az adaptáció elismerése, az Európával való viszonyban gyógyított volna mélyen gyökerező bizonytalanságokat és önbizalmi problémákat.

A török visszarendeződést felfoghatjuk a „sekély európaizáció”, „Patyomkin európaizáció” egyfajta kiadásának is. Ez a nem megfelelően mély vagy nem végrehajtott európaizációt jelenti. A kifejezés arra utal, hogy előfordulhat, hogy bár jogszabályok, intézmények szintjén megvalósul az adaptáció, de a EU nem fejt ki akkulturációs hatást, a kulturális minták nem közelednek, a demokratizációs/modernizációs hatás korlátozott marad.

Az europeanizáció mélységét, minőségét (politika-társadalom) mellett társadalmi hatása is felvet megválaszolandó kérdéseket. A kisebbségi jogok kiterjesztésének vagy megfelelő kezelésének ügye önkéntelenül ráirányította a figyelmet a kisebbségekre, ezzel azt a nem kívánt hatást keltve, hogy a török társadalomba egy homogénebb társadalmi kép helyett, a politikai 
diskurzus megváltozása miatt, a „mi-ők” dichotomiájában interpretálódik a kérdés, ezzel addig nem, vagy csupán látensen meglévő feszültségeket hozva a felszínre, erősítve az exkluziv identitások rögződését, sőt megerősödését. Ez a példa is szemlélteti, hogy az EU-török viszony nem tekinthető egyirányú, kétdimenziós kapcsolatnak és az „átcsordulás” (spill-over) sem minden szempontból problémamentes.

Közhely, hogy a politikai kultúra és a társadalmi beidegződések meggyökereséhez sokkal több idő kell, mint a polititikai intézmények vagy a gazdaság átalakításához. A török esetben mindenképp meg kell különböztetni az europeanizáció politikai és intézményi karakterének beépítését a társadalmi környezet megváltozásától. Ez utóbbi, tehát az identitás és a politikai kultúra „soft” terrénumára vezet bennünket és az akkulturáció, a politikai kultúra vizsgálatát teszi szükségessé.

\subsection{A török demokrácia sajátosságai}

\subsubsection{A hadsereg és a török demokrácia}

A dolgozat központi eleme az AK Parti időszaka alatt végbemenő demokratizálódás hosszú, és nehézkes folyamata, amelynek legfontosabb elemét a hadsereg és a „civilek”, s a legitim módon megválasztott kormány kapcsolata jelentette. A disszertáció további részében részletesen kifejtjük, milyen állomásai voltak, s hogyan alakult a török hadsereg és az AK Parti válságoktól sem mentes kapcsolata, ezen a helyen elsősorban az elméleti kerettel foglalkozunk. Ez az elméleti keret hivatott rávilágítani a katonai-civil kapcsolatok bonyolultságára és tipológiájának nehézségeire is. Ugyanitt ki kell emelnünk, hogy nemcsak a katonai-civil kapcsolatok mentek át jelentős változáson, de a katonaság is. Márton Andrea beosztása az alábbiak szerint határozza meg a katonaság átalakulását az utóbbi évtizedekre vonatkozóan (MÁRTON, 2011, 2): 


\begin{tabular}{|c|c|c|c|}
\hline $\begin{array}{l}\text { A változás } \\
\text { faktorai }\end{array}$ & $\begin{array}{c}\text { Hidegháború } \\
\text { előtti }\end{array}$ & $\begin{array}{c}\text { Hidegháború } \\
\text { alatti }\end{array}$ & $\begin{array}{c}\text { Hidegháború } \\
\text { utáni }\end{array}$ \\
\hline Fenyegetettség & Ellenséges invázió & Nukleáris háború & $\begin{array}{c}\text { Regionális és } \\
\text { szubregionális } \\
\text { konfliktusok }\end{array}$ \\
\hline Fő feladat & Haza védelme & $\begin{array}{l}\text { Szövetség } \\
\text { támogatása }\end{array}$ & $\begin{array}{l}\text { Új feladatok (pl. } \\
\text { béketeremtés) }\end{array}$ \\
\hline $\begin{array}{l}\text { Haderő } \\
\text { struktúrája }\end{array}$ & $\begin{array}{c}\text { Tömeghadseregek, } \\
\text { sorkötelezettség }\end{array}$ & $\begin{array}{c}\text { Nagy professzionális } \\
\text { hadseregek }\end{array}$ & $\begin{array}{c}\text { Kis } \\
\text { professzionális } \\
\text { hadseregek, kis } \\
\text { tartalék erők }\end{array}$ \\
\hline $\begin{array}{l}\text { Domináns } \\
\text { katonai vezető }\end{array}$ & Harcvezetők & $\begin{array}{l}\text { Menedzser/ } \\
\text { Technikus }\end{array}$ & $\begin{array}{l}\text { Katonadiplomata, } \\
\text { vezetőmenedzser }\end{array}$ \\
\hline
\end{tabular}

1. táblázat: A hadsereg változásának szakaszai

A táblázat alapján is látható, hogy a hidegháború után a hadseregek merőben új helyzetbe kerültek. Átalakultak a korábbi kihívások, új feladatok jelentek meg, amelyek összességében a hadseregek belső struktúrájának változásához vezettek. Nem volt ez másképp Törökországban sem, ahol a hadsereg létszáma jelentősen csökkent az AK Parti kormányai alatt. Azonban ennél is fontosabb változás volt, hogy átalakult a kormány és a katonaság viszonya is.

A civil-katonai kapcsolatokról jelentős szakirodalom áll rendelkezésre. Ezek közül sokan a török példát egy sajátságos esetnek tartják. Egeresi Zoltán a Zeki Sarigil által a civilek és a katonaság kapcsolatára alkalmazott négyes felosztást felhasználva amellett érvel, hogy a török hadsereg nehezen besorolható példa. (EGERESI, 2015, 1) A négyes felosztás szerint van egy professzionális, egy nemzeti hadsereg, egy irányító praetoriánus és népi praetoriánus típus. A Római Birodalom idején praetoriánusoknak nevezték a hadvezérek testőrségét. Ahol ők alkotják a fegyveres erők többségét, ott nem tud érvényesülni a civil kontroll, voltaképp a katonai diktatúráról lehet beszélni. Az utolsó példa, a népi praetoriánus jellemzi Törökországot, 
ahol a hadsereg komoly politikai tényező, de egyre inkább fokozódik a felette gyakorolt civil kontroll

Ahogy Egeresi Zoltán fogalmaz: „Ebben az esetben a hadsereg nem a hatalom megszerzése, hanem a politikai problémák megoldása érdekében avatkozik be a politikai életbe (s ezt nem is mindig kifejezetten nyilvánosan, inkább a kulisszák mögött igyekszik megtenni), ráadásul a többi rendszerhez képest a hadsereg meglehetősen magas presztízsnek örvend, és olykor a társadalom számottevő része is indokoltnak tarthatja a fellépését." (EGERESI, 2015, 2)

Noha ez a megfogalmazás megengedő, - kicsit túllép a leíró megfogalmazáson a török hadsereg szerepével szemben - azért hangsúlyoznunk kell, hogy bár a katonaság évszázadok óta nagy népszerüségnek örvend Törökországban, a katonai puccsok megítélése korántsem pozitív. Az 1980-as katonai puccs során például több tízezer embert zártak börtönökbe, sokakat kivégeztek, amely cselekmények a társadalom ellenérzését váltották ki. A katonaság által kialakított rendszerben a hadseregnek komoly beleszólása volt a legitim módon megválasztott, társadalmi felhatalmazást megszerző kormányok munkájába, s ez a 2010-es évekig tartó gyakorlat kétségeket vethet fel a török demokrácia müködését illetően.

A polgári demokráciákban a hadsereg és a civilek kapcsolatának bemutatására két markáns elmélet született. Az egyik a híres amerikai politológushoz, Samuel P. Huntingtonhoz kapcsolódik, aki szerint ,a polgári demokrácia ideális megoldása a társadalomtól és a politikától élesen elválasztott haderő. Ez a haderő teljesen apolitikus, és kizárólag a politikai döntések végrehajtására törekszik, nem bírálja, nem egészíti ki őket. Az elmélet gyakorlati megjelenési formája az, hogy a polgári és a katonai területek teljesen szétválnak és a polgári döntéshozói folyamat elsőbbséget élvez a katonaival szemben.” (LÜKÖ, 2003, 20) Huntington volt az első, aki a katonaságról, mint egy szakmáról írt, amelyet szakmaiság (erőszak alkalmazásának tudománya), felelősség (az állam biztonsága érdekében) és korporatív szellem (öntudatos, szakmához kötődő identitás) jellemez. Véleménye szerint, ha egy hadsereg professzionális, az következésképp garantálja a civil irányítást. (WILLIAM, 2007, 91)

Ezzel szemben áll Morris Janowitz elmélete, aki úgy véli, hogy nem valósítható meg a katonaság és a polgári szféra elválasztása egymástól, sőt, az a kívánatos, ha minél több kapcsolat van e két terület között. Szerinte az a megfelelő kapcsolat, ha a hadsereg tagjai betartják a demokratikus játékszabályokat, és annak engedelmeskedve hajlandóak elfogadni a polgári kormányzatokat. Tehát ,,a társadalom és a katonák közötti kapcsolatot nem csökkenteni, megszüntetni kell, hanem éppen ellenkezőleg, növelni kell, hogy ugyanazon értékek jellemezzék a hivatásos katonákat, mint a polgárokat.” (LÜKÖ, 2007, 21) A szeparációnak és 
az integrálásnak is nevezhető modellek elméleti hátterül szolgáltak ahhoz a kutatásokhoz, amelyek a katonai beavatkozások gyakorlati következményeit vizsgálták, különös tekintettel a szélsőséges esetre, a puccsra és a megfelelő civil kontroll meghatározására.

A két nagy teoretikus nyomdokain haladva még számos kutató és gondolkodó foglalkozott a civil-katonai kapcsolatokkal, különösen az Egyesült Államokban. Peter D. Feaver érdeklődési körének középpontjában a katonai puccs veszélye és annak megakadályozása állt. Hogyan lehet erős a hadsereg, hogy el tudja látni feladatát, úgy, hogy ne jelentsen veszélyt a demokratikus intézményekre? (WILLIAM, 2007, 96) Feaver ezt az ügynök problémával látja elkerülhetőnek, ahol a civil kormányzat ellenőrzi és keményen bünteti a katonaság túlkapásait. Ezt a kontrollt több tényezőhöz köti, így például az elnök személyéhez, s a katonai vezetők személyiségéhez. Megállapítása szerint a civileknek kell a végső döntést meghozniuk.

Michael C. Desch számára a legnagyobb kérdés nem egy katonai puccs lehetősége, hanem az, hogy a civil vezetők képesek-e engedelmességre bírni a hadsereget, amikor a katonai és a civil vélemények különböznek. Úgy véli, hogy a civil kontroll akkor a legerősebb, amikor nemzetközi kihívásokkal kell szembenéznie az államnak, míg a belső kihívások esetén a leggyengébb. Harold Lasswell nézőpontjával teljes ellentétben áll ez a nézet, mivel ő úgy gondolta, hogy egy helyőrség- állam (garrison state) elhúzódó nemzetközi válság esetén fog kialakulni. (WILLIAM, 2007, 98) Desch és Laswell tehát a konfliktusok típusa szerint ítéli meg a civil kontrollt, és egyértelmüen megkülönbözteti a nemzetközi és belföldi kihívásokra adott válaszokat. A bőséges amerikai szakirodalom mellett a tudományos kutatás az európai civilkatonai kapcsolatok vizsgálatára is kiterjedt. Különösen 1991 után nőtt meg az érdeklődés, amikor a hidegháború végével a kelet-európai államokban véget ért a kommunizmus, s a demokratikus átmenet révén megváltozott a kormányzatok és a hadsereg viszonya. Az átfogó, európai modellekkel foglalkozó művek már sok esetben tárgyalják Törökországot is, illetve rangsorolják az országot ezekben a modellekben.

Az európai modellekkel foglalkozó szerzők közül az egyik legátfogóbb művet Anthony Forster írta. Szociológiai szempontból vizsgálva, a társadalom és a fegyveres erők kapcsolatára három kategóriát állított fel: a meggyengült kapuőr hadsereg, a megosztott kapuőr hadsereg és az erős kapuőr hadsereg (strong gatekeeper military). Szerinte Törökország az utóbbi csoportba tartozik, többek között Albánia, Horvátország, Grúzia, Románia, Oroszország és Ukrajna mellett. (FORSTER, 2006, 115)

Melyek a jellegzetességei ennek a hadseregnek? A fegyveres erők döntőbíróként betöltött pozíciója nem változott, és kevés reformot hajtottak végre a nemi egyenlőséget (például a nők belépése a katonaságba) és a munkavállalási jogokat illetően. Ezekben az államokban a 
vizsgálat idején a civil társadalom gyenge, a munkavállalói, az emberi jogok fejletlenek, és ezek az országok nem csatlakoztak az Európai Unióhoz, ahogy az európaizálódás folyamata sem, vagy csak korlátozottan érintette azokat. A hadsereg szerepének átalakítására a társadalom fejletlenségéből adódóan kevés nyomás érkezik, s a fegyveres erők nagyon hasonlóak ahhoz a szintén fejletlen társadalomhoz, amelyben helyet kaptak. (FORSTER, 2006, 130)

Véleményünk szerint bár Forster kategorizálása terjedelméből fakadóan alapos, s több viszonylatban megállja a helyét, a megjelenése óta eltelt tíz évben bekövetkező változások részben felülírják ezt a csoportosítást. Igaz ez Törökországra is, ahol jelentős elörelépés történt a társadalmi változások terén, $\mathrm{s}$ megerösödött a civil társadalom és a hadsereg korábban kedvezményezett, erős pozíciója is visszaszorult a civil kormányzatok ellenében.

A civil-katonai kapcsolatok vizsgálatára többféle kategorizálás született. Rebecca L. Schiff az „Összhang-modell” bevezetésével kívánta új megközelítésbe helyezni ezeket a kapcsolatokat. (SCHIFF, 1995, 7-24) A fő kérdés Schiffnél is a katonai beavatkozás lehetősége. A három szereplö - a politikai elit, a hadsereg és a társadalom - négy területen elért összhangja jelentősen csökkenti a katonai hatalomátvétel lehetőségét. Ezeken a területeken, így a katonai hivatásrend kialakítása, a politikai döntéshozatal folyamata, a toborzás módja, és a hadsereg stílusa (a katonaságról a társadalomban élő percepció, a hivatásrend ethosza) terén megvalósított együttműködés jelentősen megkönnyíti a civil kontrollt.

A török hadsereg szerepével foglalkozó szakirodalomban az egyik legrészletesebb áttekintést Nilüfer Narli adja. (NARLI, 2005, 229-258) Narli résztelesen elemzi és bemutatja a Köztársaság kikiáltása óta eltelt időszakban a török honvédség szerepét és a civil kormányzatokhoz füződő viszonyát. Megállapítja, hogy a kapcsolat folyamatosan változott, s hol erőteljesebben érvényesült a civil ellenőrzés, hol kevésbé, s valamikor egyértelmüen a katonai hatalom határozta meg az országban az események folyását.

\subsubsection{A szekularizmus és a demokrácia Törökországban}

Az AK Parti kormányzása alatt az egyik legnagyobb gondot a szekularizmus körül kialakult viták jelentették. A demokráciának sok feltétele van, azonban a kulturális tényezőt ki kell emelni. A közismert demokrácia-kutató, Giovanni Sartori kijelenti, hogy „a kulturális tényezők közt a vallási tényezőnek sokkal nagyobb súlya lehet, mint a gazdasági vagy társadalmigazdasági feltételeknek. Ezzel kapcsolatban elegendő azt megjegyezni, hogy még 1990-ben is alig találunk a világban olyan országokat, ahol teljes mértékben érvényesül a demokrácia. Az 
iszlám térségben ebből a szempontból mindmáig nem jelent különbséget a gazdagság (gondoljunk az olajforrásokban gazdag államokra) és a szegénység." (SARTORI, 1999, 192)

A szekularizmus kifejezésre török nyelven a francia eredetű „laiklik” szót használjuk. A fogalom a vallás és az államigazgatás elválasztására vonatkozik, kimondja, hogy a vallás irányában az államnak semlegesnek kell lennie. Ugyanakkor magát a szekularizáció folyamatát nemcsak az állam és a vallás kapcsolatának leírására, hanem sokkal szélesebb értelemben is használják. Tehát az emberek saját, belső vallásosságának megélésében történt változásokat is sokszor ezzel a fogalommal azonosítják.

A szekularizmus és laicitás fogalmának elválasztására Öztürk hívja fel a figyelmet. A laicitás a közszférában az állami kontroll gyakorlása, míg a szekularizmus az állam és az egyház elválasztását jelenti. Míg a szekularizmusnak vallásellenes felhangja volt, a laicitásnak nem, és arra utalt, hogy az államnak nem szabad egyetlen egyházat sem kedvezményezettként kezelni, viszont vak sem lehet a vallás kérdéseiben.

A francia forradalom óta zajló társadalmi és gazdasági változások révén számos országban - elsősorban a keresztény országokban - az emberek elfordultak az egyháztól, kevésbé vallásosakká váltak. Ez a vallástalanodás Nyugat-Európában régóta tartó folyamat, amely a legtöbb országot érinti. Ezzel szemben a muszlim világban - így Törökországban is - a lakosság vallásosabb, mecsetekbe jár és a vallásosság megélése a hétköznapokban egyáltalán nem tűnt el, nem szorult vissza, mint Európában. A vallásosak száma a statisztikák szerint igen magas Törökországban. Egy 2009-es felmérésben a megkérdezettek 95 százaléka nyilatkozta azt, hogy Allah létezik. Az emberek 89 százaléka hisz a halál utáni életben, 93 százalékuk hisz a mennyország és a pokol létezésében. A megkérdezettek közel 90 százaléka mondta azt a kérdőíven feltett kérdésre, hogy magát vallásosnak tartja, amely a legmagasabb érték volt a többi európai országhoz képest. (CARKOGLU-KALAYCIOGLU, 2010)

Az egyén szintjén kevéssé érezhetők a szekularizáció hatásai Törökországban, az európaihoz képest sokkal vallásosabb társadalomról beszélhetünk. Mit jelent a szekularizmus egy olyan országban, ahol muszlim ország révén nincs egyház, tehát elvileg nincs mit szétválasztani az államtól?

Ehhez a 20. század elejének eseményeit kell megvizsgálnunk. Mustafa Kemal Atatürk hatalmas harcok árán kivívta az ország függetlenségét, majd az Oszmán Birodalom romjain létrehozta az új és modern Törökországot. Reformpolitikája során a kor mintaállama, Franciaország lebegett a szeme előtt, és a modern állam minél több jellemzőjét át kívánta venni. Ekkor vezették be a latin abécét, a mélyreható oktatási reformokat, ekkor törölték el a 
szultanátus és a kalifátus intézményét. Ugyanekkor került sor a vallás és az állam szerepének újragondolására, amely esetben, mint említettük, Franciaország volt a követendő példa.

A francia állam 1905-ben fogadta el az egyház és az állam teljes szétválasztásáról szóló törvényt. A szekularizmus kemény válfaját megvalósító törvény révén az egyházat kiszorították a közintézményekből. Az oktatás világi lett, még a vallási jelképek használatát is kitiltották az iskolákból, és az egyház a korábbi állami támogatást is elveszítette. Ez a változás a legbefolyásosabb felekezetet, a római katolikusokat érintette leginkább. A római katolikus egyház korábban a politikát is igyekezett befolyásolni, azonban innentől kezdve sokkal kisebb beleszólása lett az állam ügyeibe.

Mustafa Kemal Atatürk egy ehhez hasonló reformot kívánt megvalósítani, azonban Törökországban ez egy államilag ellenőrzött vallási intézményrendszer, a napjainkban röviden csak Diyanetnek nevezett vallási elnökség - korábban minisztérium - felállításával járt. Ebben a rendszerben a vallási közösségek már nem maguk választották az imámjaikat, hanem az állam nevezte ki és helyezte át az ország egyik pontjából a másikba őket, akik így egyszerü állami közalkalmazottakká váltak. Mivel Atatürk a francia példát vette modernizációs programjának alapjául, ezért a közhivatalokból is kitiltotta a vallási jelképeket. Ez a kemalista értelmezésben mind a mai napig irányelv maradt.

Az AK Parti ezzel szemben a szekularizmus egy sokkal „puhább” értelmezését vallja magáénak, amiről a párt egy 2006-os önazonosság-kereső dokumentumában így vallanak: „,Az AK Parti a szekularizmust a demokrácia egyik legfontosabb alapfeltételeként vallja. A szekularizmus mögött meghúzódó gondolat az, hogy az államnak pártatlannak kell maradnia minden vallásos hit és filozófia irányában. Ebben az értelemben a szekularizmus a szabadság egyik záloga. Ez azt is jelenti, hogy a szekularizmus nem az egyént, hanem az államot korlátozza.” (AK PARTI Kurum Kimligi Kilavuzu, 2006, 14) Az AK Parti a saját felfogása párhuzamos az Amerikai Egyesült Államokban tapasztalhatóval. Az alapvetően protestáns Egyesült Államokban sok kisegyház létezik - a katolikus és a nagy protestáns felekezetek, mint a reformátusok vagy evangélikusok mellett-, és a lakosság is vallásosabb a nyugat-európai országokban tapasztaltakhoz képest. Nem célunk az amerikai vallásosság okainak firtatása, azonban ki kell emelnünk az amerikai szekularizmus egyik sajátosságát. Az állam az Egyesült Államokban sem kíván beleszólni a vallási ügyekbe, az alkotmány kimondja, hogy az állam indifferens a vallás irányában. Azonban ez Franciaországgal ellentétben nem jelenti, hogy a vallás, a vallásosság megítélése kiszorult volna a politikából. A vallási csoportok nagyon aktívak és az egyén és a politikus vallásosságának megélése, a vallási jelképek megjelenítése bevett szokás az országban. A szekularizmus ezt a formáját a szakirodalom a „puha” jelzővel 
látta el, jelezvén, hogy ez sokkal megengedőbb a vallás közéleti szerepével szemben, noha megtartja az állam és a vallás közti távolságot.

A török szekularizációra úgy tekintek a hipotéziseimben, hogy az a politikai berendezkedés egy olyan eleme, ami biztosítani hivatott:

- a szabad vallásgyakorlást,

- a vallásukat nem gyakorlók vagy nem vallásosak szabadságát,

- a vallási kisebbségek szabad vallásgyakorlását,

-a muszlim vallási közösségek (dzsemaat) és szúfi testvéri közösségek (tarikat) elkülönítését az államgépezettől,

- a világi törvénykezés kizárólagosságát,

- az állami közoktatás vallássemlegességét, ami nem zárja ki a hitoktatást, és a "fait religieux", azaz a vallásokkal kapcsolatos tényanyag oktatását.

Öztürk a török Diyanet és az AK Parti viszonyát elemző munkája a szekularizációt tekintve a török elemzők között három markáns álláspontot különít el. A szekularizációt mint a török hagyományban gyökerező és azt továbbvívő jelenséget láttatja, amely a jogi keret, valamint a politikai és vallási gyakorlat szempontjából különül el. Az első megközelítés az ottomán jog és gyakorlat terén a földi és vallási terek elkülönülését hangsúylozza a jogrendben, a spirituális/egyházi jogot az iszlám saría jog alapján értelmezi és azt állítja, hogy a modern értelemben a szekuláris szférától ez nem különült el, de fokozatos szekularizációról beszélhetünk. A köztársasági és a megelőző 1908-18 közti Ifjú török időszak tehát egy folyamat felgyorsulását mutatja csupán, nem cezúra, hanem az ottoman múltban elkezdett folyamat folytatása. Bizonyítékül, Halil Inalcikot idézve a szerző megállapítja, hogy a szultánok hatalma, legitimitása nem kizárólag kalifa státuszukból volt eredeztethető, hanem katonai és törvényi forrásból is. A második megközelítés szakít az előbbi elképzeléssel és tagadja, hogy a különbség „ugyanannak az érmének a két oldala” lenne. Az ottomán szultánok integrált hatalomgyakorlása során törvényi és spirituális hatalmat is gyakoroltak (uralkodó-kalifa), amelynek alapját egy egységes „,szunni iszlám intézményi kód” alkotta, amely két regiszterrel rendelkezett: egy spirituálissal és egy világival. Az egységes szemlélet azt jelenti, hogy az iszlám olyan inklúzív vallás, amely az élet minden szféráját magába foglalja, az állami hatalomgyakorlást, a kormányzást is. A republikánus korszak szekularizációja tehát ebben az értelmezésben radikális szakítás az „egységesség” hagyománnyal szemben. Harmadsorban, az ottomán hagyomány kontinuitását hangsúlyozva a különleges török berendezkedés kap 
hangsúlyt. Az ottoman/török tradíció az olyan állami hatalomgyakorlást jelenti, amelyben az egyházi, vallási ügyeket a központi kormány szabályozza. Az ottoman hagyomány továbbélését abban is felfedezhetjük, hogy a kalifa/szultán a vallási vezetők kinevezésének, leváltásának jogával bírt, sőt, a Seyhülislam a szultán nevében hozott döntéseket. Az autonóm vallási hatalom nem létezett, az egyházi ügyek az állam alá tartoztak.

Heinz Kramer még az AK Parti hatalomra kerülése előtt megjelent könyvében kritikáját fejezte ki a szekularizmus felülről történő olyan bevezetéséről, amely nem tette lehetővé a személy számára szabadságjogainak és a demokráciának a biztosítását, amivel a vallásos muszlimokat elidegenítette, akik, mint láttuk, a török társadalom számottevő részét alkotják. Ez a kemény szekularizmus kizárta vagy erőteljesen korlátozta az iszlám politikai megjelenését és annak társadalmi megélését.

Tárgyalnunk kell Ümit Cizre Sakallığlu tanulmánykötetét, amelyben az AK Partit vette górcső alá. (SAKALLIOGLU, 2008, 1-13) A kötetben szereplő megállapítások szerint a törökországi iszlamizmus több szempontból is különleges esetnek tekinthető. A törökországi ulema, azaz a muszlim vallástudósok közössége gyenge a többi muszlim államban lévő ulemához képest az oszmán idők óta, amikor egy nagyon kiterjedt és erős állami bürokrácia jött létre. A törökországi iszlamizmus további sajátosságát az adja, hogy a törökországi iszlamista értelmiség ,át van itatva” a szúfizmussal, amely eleve elveti a radikalizmust és az államellenes tevékenységet. A törökországi iszlám alapvetően megmaradt nemzeti keretek között, s kevéssé kapcsolódik a nemzetközi iszlamista mozgalmakhoz, még akkor is, ha azok korlátozott hatását nem lehet kizárni. Negyedik okként megemlítendő, hogy Törökországban nem volt gyarmati múlt, ami miatt az iszlamista mozgalmak az arab világban látható antikolonializmushoz nyúlhatnának. Emiatt a törökországi iszlamista körökben kedvezőbb a Nyugat megítélése. A könyv továbbá hangsúlyozza, hogy a törökországi iszlamizmus eleve nem egységes, mivel rengeteg csoport alkotja, mint a nurcuk, a naksibendik stb. Végezetül megállapítják, hogy az iszlamista vezetők az oktatáson keresztül is egy szekularizációs folyamaton mentek keresztül, ami eleve mérsékelt irányt ad az iszlamisták követeléseinek.

A könyv szerint napjaink törökországi politikai iszlámjában két tendencia érvényesül. Az egyik az AK Parti egyik szellemi elödjéhez, a Necmettin Erbakan által alapított Milli Görüşhöz kapcsolódik, amelyből kinőtt a jelenlegi Saadet Partisi. A másik csoportot az AK Parti testesíti meg, amely megpróbálja összeegyeztetni az iszlámot a nyugati modernitással és a kapitalizmussal. Az AK Parti a kötet szerint inkább konzervatívként és demokrataként határozza meg önmagát, s nem pedig iszlamistaként. Olyan párt, amely elfogadva a kulturális jogok, emberi jogok fontosságát egy másfajta szekularizmust képvisel, mint a keményvonalas 
kemalisták. Az AK Parti szekularizmusa sokkal megengedőbb a vallásosabb muszlimok hitéletének, vallásos érzéseinek megélésének irányában, mint a hagyományos szekuláris körök.

Az AK Parti szekularizmusa nem függetleníthető a török politikai élet egészétől. Az évtizedeken át ható kemalista-szekularista megközelítés meghatározta és meghatározza az AK Partival szembeni elvárásokat is. „Miután az AK Parti egy kemalista-szekuláris környezetbe került, a párt célja az lett, hogy ragaszkodjon a demokratikus értékekhez, a kemalisták viszont azért kezdtek aggódni, hogy megmarad-e a szekuláris rendszer, és ez feszült politikai légkört eredményezett" (DOGANAY, 2014, 66)

Az AK Parti politikájában az 2008-as év ellenzéki kihívásai miatt fordulat következett be. Az új felfogás szerint „,a szekularizmust nem a vallás betiltásával, hanem a vallásszabadság előmozdításával lehet megvalósítani. Ebben a korban a más vallások és kultúrák megóvásával, és a saját vallásunk és kultúránk mozgástere szélesítésével érhető el a szabadság”. (BOSTANCI-UCMA-YETIS, 20)

Az AK Parti a 2008-as betiltási kísérlet előtt valójában kevéssé foglalkozott vallási kérdésekkel. 2010 után viszont érezhetően megnőtt azon döntések és politikai kezdeményezések száma, melyekkel a kormány a vallásos tömegeknek szeretett volna kedvezni. Ilyen volt az a lépés is, mikor korlátozták az alkohol forgalmazását az esti órákban. E változás mögött az állhat, hogy az $\mathrm{AK}$ Parti ekkorra már több választást is megnyert, ezzel maga mögött érezhette a rendszeresen vallásukat gyakorlókat, ami pedig utat nyitott további kételyeknek, és persze kritikáknak is, amit Murat Somer így fogalmaz meg: ,amint hatalmában állt változtatni a laiklik-on, az AK Parti mindent megtett, hogy változtasson azon azzal, hogy leginkább a laiklik egyik oldalára, annak demokratikus deficitjére koncentrált. Anélkül, hogy csökkentette volna az állam befolyását és demokratizálta volna az államvallásokhoz való viszonyát, a hatalmát arra használta fel, hogy a vallást terjessze mind társadalmi, mind államhatalmi szinten.” (SOMER, 2015, 35-36) A vallás tehát ily módon a választói akarat kielégítésére szolgált, de szerepe volt abban is, hogy az állam ,alá” vont egyházi intézmények által a vallás az államhatalom nemzeti identitást, a kormányzati ideológiát szolgáló eszköze legyen.

Az elméleti keretek felállításával megállapíthatjuk, hogy az AK Parti kormányzása idején zajló demokratizációs folyamatok megértéséhez sok lehetőséggel élhetünk. Maga a demokrácia felfogás, annak értelmezése is rengeteg kérdést vet fel a szakirodalomban, emiatt itt a demokrácia intézményét és törvényi hátterét egyrészt a szabad választások és az alkotmányjogi keretek biztosítása, másrészt a civil hatalmat és vezetést veszélyeztető hadsereg szerepének változása alapján kívánjuk vizsgálni. Ebben azonban nagyon fontos szerepet kapnak a 
kisebbségek képviseletének és kulturális jogainak biztosítására tett erőfeszítések és a szekularizmus kérdése, amellyel az AK Parti szintén a liberalizmus jegyében kívánta kielégíteni szavazóinak, tehát a török nép számottevő részének kívánságát.

\subsection{A török demokrácia története, a mai pártrendszer kialakulása}

\subsubsection{A köztársaság kikiáltása, az atatürki reformok}

A modern török demokrácia kialakulásának megértéséhez át kell tekintenünk annak előzményeit. A mai török állam egy parlamentáris köztársaság, ahol a hatalmi ágak szétválasztása és a szekuláris berendezkedés teremti meg az állammüködés alapjait. Ez a rendszer létrejöttekor célul tủzte ki az európai demokráciák hagyományainak átvételét, és egyben jelentős mértékben szakított is a múlttal, az Oszmán Birodalommal. A török monarchia ugyanis az iszlám vallás jogrendszerét igyekezett alkalmazni, miközben egyre inkább érezhető volt müködésén a nyugati hatás: a felvilágosult abszolutizmus inspirációjára már a 18. század végétől kezdve több reformot is végrehajtottak az uralkodók. Az I. világháború után nem csupán egy iszlám világbirodalmat váltott fel a területileg is jóval kisebb Török Köztársaság, hanem reformjai révén egy egész kormányzati berendezkedést, a kalifátus intézményét is eltörölte, ami az egész iszlám világra kihatott.

A kalifátus megszüntetése, az új Török Köztársaság megalakulása és a máig is létező szekuláris berendezkedés megálmodója és megvalósítója Musztafa Kemál Atatürk volt. Atatürk - aki egyben a honvédő háború hőse is - személyes részvétele a rendszer alapjainak letételében olyan mértékü volt, hogy a reformoktól azt elválasztani képtelenség, a köztársasági szisztéma megszületését ezért joggal nevezhetjük atatürki reformoknak. A „törökök atyja”, Atatürk egyébként igyekezett kihangsúlyozni azt, hogy a köztársaság egy hosszú távú politikai projekt, amelynek végső sikere független az alapító személyétől. Miután 1926-ban a délnyugattörökországi Izmirben merényletet kíséreltek meg ellene, az egyik beszédében a következőket mondta: „az én múlandó testem egy nap mindenképpen porrá lesz, de a Török Köztársaság mindörökké fennmarad." (SOYAK, 1973, 368)

Atatürk reformjai az élet négy területét érintik. Beszélhetünk politikai, jogi, kulturális és gazdasági reformokról. A politikai reformok - szemben az oszmánok zömmel a politikai elitet érintő döntéseivel - a teljes államberendezkedés megváltoztatását célozták, annak hatásai minden egyes török állampolgárra nézve egyértelmủek voltak. A rendszerváltás alapját az első világháborút lezáró béke adta, amely lehetővé tette azt is, hogy Törökországban szabad 
választásokat tarthassanak. Ám erre csak évtizedekkel később került sor a valóságban. A legfontosabb politikai változások a már említetteken túl a nők jogainak kiszélesítése tárgyában születtek. Elmondható, hogy megtörtént a nők egyenjogúsítása. Ezen kívül témám szempontjából lényeges elem, hogy kísérlet történt a többpártrendszer bevezetésére és megszilárdítására, ám végül Atatürk pártja, az 1924-ben Néppárt néven induló, ma Köztársasági Néppárt néven ismert formáció maradt az egyedüli legális politikai erő.

A társadalmi reformok a vallásos hagyományok háttérbe szorítása mellett a nyugati ízlés elterjesztését jelentették. Betiltották a hagyományos török muszlim viseleteket, és elöírták, hogy nyugatias kalapokban kell járnia a férfiaknak. Felszámolták a misztikus testvériségeket, az ún. dervis rendeket, ezzel a rendelettel a népi vallásosságot szerették volna korlátozni. A kulturális reformok leginkább az oktatás területén hoztak nagy változást. Megszüntek a medresszék, a hagyományos iszlám tanintézetek, helyettük a népi irodákban tanulhatta meg újra a török a betüvetést, hiszen az arab betük helyett a latin ABC-t tették hivatalossá 1928-ban. Atatürk a közoktatás mellett a felsőoktatást is megreformálta, illetve új tudományos intézeteket hozott létre a török nyelv és a török irodalom kutatására.

Amíg Atatürk politikai és társadalmi reformjait radikalizmusuk, oszmán- és valláskritikusságuk miatt bírálat érheti, addig kétségtelen, hogy a „törökök atyja” gazdasági téren egy jól működő, szociális piacgazdaság alapjait fektette le. Felszámolva a feudális maradványokat, teljes földreformot vezetett be, a mezőgazdaságban mintagazdaságokat létesített, az ipar és a kereskedelem területén pedig megalakulhattak a kamarák, mint érdekvédelmi testületek. Az 1927-ben bevezetésre kerülő ipari törvény komoly befektetésélénkítő hatással járt, hiszen ösztönzők hosszú sorát tartalmazta. Ezzel megszülethetett egy új, pénzügyi és befektetői elit, mely Atatürk és a Köztársasági Néppárt fő támogatója lett, és maradt egészen a 2000-es évek elejéig.

\subsubsection{Törökország demokratikus fordulata az 50-es években}

Miután Törökország sikeresen kimaradt a II. világháború borzalmaiból, ugyanakkor a Szovjetunió megerősödésével új fenyegetés jelent meg a keleti határainál, amely az új, immár hidegháborús világrendben a Nyugat felé orientálta az országot, a politikai berendezkedés módosítására is sor kerülhetett. 1945-ben beindulhatott egy óvatos politikai liberalizáció, amelynek egyik lényeges eleme a többpártrendszert bevezetése volt, amely lépés a török demokrácia történetének az egyik legfontosabb cezúrája. Az előző korszakot egypártrendszerü, az azt követőt pedig többpártrendszerü időszaknak nevezzük. Az első új párt a szultanátus kései 
korának ellenzéki személyiségeiből alakult meg. A Nemzeti Fejlesztési Párt (Milli Kalkınma Partisi, MKP) (AVSAR-KAYA, 2012, 113) élén azt a Nuri Demirağ-t találjuk, aki vállalkozóként Atatürk idején azzal gazdagodott meg, hogy kiépítette az anatóliai vasúthálózatot. Bármennyire is az MKP volt az első új párt, az első demokratikusnak mondott választásokon (többpárti voksolás már 1946-ban is volt!), 1950-ben be sem jutottak a parlamentbe, ahol a többséget a kemalista, azaz Musztafa Kemál Atatürk elveit és reformjait támogató Köztársasági Néppárt (CHP) előtt a Celal Bayar vezette demokraták (DP) szerezték meg.

Az 1940-es évek második felében és az 1950-es években kialakul a mai török pártrendszer elöképe, melyben már csírájában jelen volt a mai török politikai platformok négy archetípusából több is. Ezek azok az ideológiai irányzatok, amelyek máig döntően meghatározzák a török politikai palettát. A CHP tovább örökíti a korai köztársaság korának örökségét és a baloldali eszmeiséget, emellett van egy vallásos-konzervatív, egy nacionalista és egy, a kisebbségek jogai mellett kiálló politikai formáció. Az utóbbi témát eleinte nem egy önálló politikai párt testesítette meg, hanem csupán egy-egy képviselö, akik akkor még különbözö pártok padsoraiban ültek. A témám szempontjából fontos vallásos-konzervatív szerepet a ma is létező, az 1960-ban betiltott, majd 1992-ben újra megalapított, ám ma már szinte jelentéktelen Demokrata Párt (DP) vállalta fel. A vallásos-konzervatív párt Hakan Yavuz szavaival élve kétarcú, egyszerre „társadalmi és politikai értelemben haladó, támogatja a demokrácia és a piacgazdaság kiterjesztését, ám a másik oldalról konzervatív és autoriter, a társadalomban egy vallási, erkölcsi modell meglétét feltételezi”. (YAVUZ, 2005, 29)

A Demokrata Pártot 1946. január 7-én Celal Bayar hozta létre. Az első szabad és demokratikus választásokat 1950-ben ez a párt nyerte meg, a kezdeti sikereket ezután még két diadal követte 1954-ben és 1957-ben. A párt 1960-ig kormányozta az országot. Az 1950-es évek elején a DP liberális gazdaságpolitikát folytatott ugyan, de a népi-konzervatív politikai követelések megvalósítására is törekedett. A kormányt vezető Adnan Menderes politikáját egyszerre nevezhetjük liberálisnak - gazdasági értelemben -, és populistának - politikai értelemben -, mivel támogatta a külföldi befektetéseket, külhonban vett fel hiteleket azért, hogy látványos gazdasági növekedést produkáljon az ország, ami az infláció megugrását is eredményezte. Ugyanakkor a vallásos néptömegek igényeit is igyekezett kielégíteni azzal például, hogy támogatta a hitoktatást, engedélyezte az iszlámról szóló müsorokat a rádióban, és lehetővé tette, hogy az addig nagyjából titokban működő testvéri közösségek legális alapokon folytathassák müködésüket. (BAYTAL, 2007, 545-567) 
A török pártrendszer színesedésére jellemző, hogy a két vezető párt mellett más alakulatok is igyekeztek beleszólni az ország sorsának alakulásába. Ilyen volt a Nemzeti Párt (Millet Partisi, MP), amely a demokraták belső ellenzékéből fejlődött ki a honvédő háború hőse, Fevzi Çakmak tábornok irányítása alatt. A párt 1948-ban azért indult útjára, mert úgy tartották, hogy a DP csupán puha ellenlábasa a CHP-nek. A kemalistákat túlzott szekularizmussal vádolták, egykori párttársaikról pedig azt állították, hogy lepaktáltak a baloldallal. „Bár Çakmak népszerü volt, a nép nem támogatta jelentős mértékben a Nemzeti Pártot, mert ahelyett, hogy a saját programjukat védték volna, a többi párt vezetőit, föleg İnönüt támadták.” (KARPAT, 2010, 40) Az 1950-es voksoláson csupán egy képviselőjük jutott be a nemzetgyülésbe. 1954-ben végül az alkotmánybíróság betiltotta, mondván programjuk ellentétes a török állam világi berendezkedésével. A betiltást követően szinte ugyanazok a politikusok életre hívták a Republikánus Nemzeti Pártot (Cumhuriyetçi Millet Partisi). Így el is tudtak indulni az 1954-es választásokon, ám csupán öt képviselői helyet szereztek.

Szintén a DP-ből távoztak azok, akik 1952-ben Ankarában bejegyeztették a Törökországi Falusiak Pártját (Türkiye Köylü Partisi). A kormány agrárpolitikájával elégedetlen képviselők célja egy, az osztályharcot elutasító, konzervatív agrárpárt megvalósítása volt, ám ez túlságosan marginális részérdeknek bizonyult, hiszen az 1954-es választásokon csupán 57 ezren szavaztak rájuk. A sikertelenséget látva a falusiak pártja egyesült a nemzetiekkel. 1958-tól kezdve Republikánus Falusiak Nemzeti Pártja (Cumhuriyetçi Köylü Millet Partisi) néven folytatták. 1969-ben felvették a Nacionalista Mozgalmi Párt (Milliyetçi Hareket Partisi, MHP) elnevezést, amit máig használnak. (ETE-TASDELEN-ERSAY, 2014) Ez tehát azt jelenti, hogy a mai nacionalista párt története az AK Partihoz hasonlóan a demokratákhoz nyúlik vissza, a DP-ből pedig azért léptek ki, mert eredetileg a vallásos néptömegek értékeinek és érdekeinek letéteményesei szerettek volna lenni, azaz a mai török nacionalizmus gyökere - meglepő módon - a mérsékelt iszlamizmus és az agrárgondolat, ami ma már kevéssé jellemző a MHP-re.

A DP aprózódása a későbbiekben is folytatódott, hiszen 19 képviselő elhagyva a pártot 1955-ben megalapította a Szabadságpártot (Hürriyet Partisi). A demokraták baloldalát jelentő honatyák az 1957-es választáson nagyon gyengén szerepeltek, és csak négy mandátumot szereztek. Ezek után a kemalista CHP-vel való egyesülésről döntöttek, ami azt jelenti, hogy volt átjárás a két nagy politikai párt között.

A török demokrácia határait feszegette a Haza Párt (Vatan Partisi) 1954-es megalakulása, hiszen annak vezetői az illegális kommunista mozgalomból érkeztek. A törvényen kívüli Törökországi Kommunista Párt 1920 óta már létezett, társadalmi hatása azonban csekély maradt. A Szovjetunió megerősödésével viszont ez a csoport is helyet keresett magának a 
pártpolitikában. Névválasztásuk figyelemre méltó, hiszen egy proletár, internacionalista ideológia képviselői vették fel a Haza Párt nevet. Már 1955-ben jogi eljárás indult ellenük egy botrányos kampánybeszéd miatt, végül 1957-ben tiltották be a pártot, mert kommunista módszereket használt. (ÜNSAL, 1996)

\subsubsection{Az államcsínyek kora}

A demokraták kormányzásának és a tízéves liberalizációs folyamatnak 1960. május 27-én egy katonai államcsíny vetett véget. A Demokrata Pártot betiltották, a kormányfőt kivégezték. Bár a kemalista és a nemzeti párt fennmaradt, az 1961-es új alkotmány talaján új pártok jöttek létre, ezek közül az Igazságosság Pártja (Adalet Partisi, AP) vitte tovább a DP hagyományait, a novemberi nemzetgyülési választásokon a voksok közel 35\%-át szerezte meg, és végül a továbbra is kemalista elveket valló CHP-vel lépett koalícióra. A török történelem első koalíciós kormányzása során a párt megerösödött és kitermelt egy karizmatikus vezetőt, Süleyman Demirelt, akinek az elnöksége alatt 1965-ben már a szavazatok többségét szerezték meg. Az elődjéhez hasonlóan gazdasági szempontból liberális, politikai szemszögből populistának nevezhető AP programjának a homlokterében az emberi szabadságjogok, a jogállam erősítése és a szociális háló megteremtése állt, az új adórendszer bevételeiből pedig az oktatást, a mezőgazdaságot és a vidékfejlesztést igyekeztek támogatni. (DEMIREL, 2004)

Bár az Igazságosság Pártjának fő szlogenje a fegyverkezés megfékezése volt, ugyanarra a sorsra jutottak, mint a szellemi előd, a DP: Demirel kormányát 1971-ben megdöntötte a katonaság. Ugyan az AP-t nem tiltották be, és Demirel is a politikai elit tagja maradt, de az ország vezetését átvette a Bülent Ecevit vezette, baloldali, nacionalista fordulaton átesett CHP.

A Demokrata Párt megszünésével keletkezett politikai ür betöltésére az AP mellett egy másik párt, a jobboldali, liberális programmal jelentkező Új Törökország Párt (Yeni Türkiye Partisi, YTP) is kísérletet tett. A választásokon 65 képviselői helyet elnyerő YTP viszont a baloldallal szövetkezett, amiért cserében egyrészt hat bársonyszéket kaptak İsmet İnönütől, másrészt jelentősen csökkent a népszerüségük, és 1965-ben már csupán 19 képviselőt tudtak delegálni a nemzetgyülésbe. Az elnökét sürün váltó párt vezetői végül maguk látták be, hogy nem ők, hanem az AP a demokraták valódi örökösei, ezért 1973-ban beszüntették a párt müködését. Ezzel azon ritka török pártok közé tartoznak, melyek nem betiltással kerültek felszámolásra.

Az 1961-es alkotmány talaján létrejött Törökország első törvényes szocialista pártja a Törökországi Munkáspárt (Türkiye İşçi Partisi, TİP). A főleg szakszervezeti aktivistákból 
verbuválódott párt az 1965-ös választásokon 15 helyet szerzett. 1968-ban Csehszlovákia megszállása kapcsán szakadás jött létre a pártban, ami azután már nem igazán állt talpra. „Az 1970-es évek folyamán ez a csoportosulás kezdett fegyveres harcot az országban egyéb maoista csoportokkal kiegészülve", míg végül 1971-ben a puccsisták betiltották. (EGERESI, 2010, 16)

Amint fentebb említésre került, a török politikai pártok archetípusai között van egy, ami a kisebbségi jogok védelmét tartja fontosnak. Azt is említettük, hogy eleinte nem egy önálló párt vállalta fel ezt a tematikát, hanem egy-egy képviselő. Az 1960-as évek demokratizálódása magával hozta azt is, hogy egy egész ilyen politikai közösség alakulhasson. Az első példa erre az 1966-ban megszülető Törökország Egysége Párt (Türkiye Birlik Partisi), mely elsősorban a síitákhoz közel álló alevi vallási kisebbség tagjaiból állt. Bár jelképében is vállaltan vallási hátterü párt volt, - hiszen nem volt más, mint az iszlám történelem negyedik kalifáját, Alit szimbolizáló oroszlán és a síiták és alevik által tisztelt tizenkét imámot felidéző tizenkét csillag -, szabadon müködött egészen 1980-ig, amikor is minden más párttal együtt betiltották a katonai puccs vezetői. A párt fénykorában (1969-ben) nyolc képviselői hellyel rendelkezett. (ATA, 2007)

Az 1970-es évek koalíciós időszakának a török történelem harmadik puccsa vetett véget 1980-ban. Ezután egy ideig nem müködhettek politikai tömörülések Törökországban.

\subsubsection{A rövid életü koalíciós kormányok időszaka}

Az 1980 és 1983 közötti éveket a demokrácia szempontjából a helyben toporgás éveinek hívja a török közvélemény, hiszen a katonai kormányzás nem jelentett elörelépést az egyre kaotikusabb helyzetben. A puccsot követően a demokrácia helyreállításának megkezdésére 1982 novemberéig kellett várni, amikor is népszavazást rendeztek a módosított alkotmányról, amit a választók több, mint $91 \%$-a el is fogadott. Az alaptörvény reformját követően megszületett az új, 2820-as számú párttörvény is, melyet 1983. április 24-én tettek közzé a török hivatalos közlönyben, a Resmi Gazetében. 1983-tól egy eléggé instabil pártrendszer jött létre, ami nem volt képes a tartós kormányzás feltételeit biztosítani. Pártok alakultak és szüntek meg, az 1991-ig tartó egypárti kormányzást követően egymást váltották a koalíciós kormányok, amelyek sokszor a mandátumukat sem töltötték ki. A nagyfokú bizonytalanság sokakat elidegenített a rendszertől, egyre többen vágytak arra, hogy egy párt végre meg tudja valósítani a választási programját, amelyre azonban egészen 2002-ig, az AK Parti hatalomra jutásáig kellett várni. 
Az 1983-as nemzetgyülési választásokon már az új jogszabály alapján létrejött pártok indultak. A parlamentbe végül három politikai erő tudott bejutni. A legtöbb képviselői helyet az AK Partival sok rokon vonást mutató, gazdasági értelemben liberális, társadalomszemléletében konzervatív Anyaföld Pártja (Anavatan Partisi, ANAP) szerezte meg, mivel elérte az abszolút többséget, s a párt vezetője, Turgut Özal önállóan alakíthatott kormányt. A pártvezér azonban 1993-ban rejtélyes körülmények között életét vesztette, és „összességében az ANAP Turgut Özal halála után nem volt képes megújulni, és új identitást találni magának", így nem tudott az 1990-es évek második felében is meghatározó erőként politizálni. (KALAYCIOGLU, 2002, 58)

Az ellenzék legfőbb erejét a Néppárt (Halkçı Parti, HP) alkotta, amely szociáldemokrata jellegü, baloldali programmal jelentkezett és a puccsisták által szintén betiltott, egykori kemalista CHP utódjának tekinthető. A balközép formáció térnyerését erősen korlátozta, hogy az új párttörvény életbe lépését követően akadt egy konkurense is, a Szociáldemokrácia Pártja (Sosyal Demokrasi Partisi, SODEP) formájában. Miután nagyjából ugyanazt a választói réteget célozták meg, 1985-ben Szociáldemokrata Néppárt (Sosyaldemokrat Halkçı Parti, SHP) néven egyesültek. Többszöri osztódást követően 1992-ben veszik vissza az államalapító Musztafa Kemál Atatürk által adott eredeti nevet, azóta a mai napig Köztársasági Néppárt néven ismertek.

Az ellenzék másik jelentős pártja a Nacionalista Demokrácia Pártja (Milliyetçi Demokrasi Partisi, MDP). A párt nem bizonyult hosszú életűnek, hiszen már 1986-ban megszünt, ugyanis többen átléptek a kormányzó ANAP-ba, mások pedig olyan új pártokat alapítottak, mint amilyen például a Szabad Demokrata Párt (Hür Demokrat Parti, HDP), vagy a Helyes Út Pártja (Doğru Yol Partisi). Ez utóbbi az 1950-es évek demokratáinak és az Igazságosság Pártja szellemi örökösének is tartotta magát, és sokkal inkább vallásos értékeket felmutató és liberális, mintsem nemzeti radikális programmal állt elö. Ez a párt 1991 és 1999 között a kormánykoalíció tagja volt, sőt az 1991-es választásokat is ők nyerték meg. Az 1991 és 1995 közötti négy év során négy különböző kormánykoalíciót adtak Törökországnak, amellyel megkezdődött az ország előbb politikai, majd gazdasági visszaesése. A 2000-es évekre nagyon sokat vesztett jelentőségéből a DYP. 2007-ben nevet is változtatott: a vallásos fogalomként is értelmezhető helyes út helyett ma a Demokrata Párt nevet használják, a 2000-es években az egykori kormánypártot szinte már csak az egyik muszlim közösség követőinek egy része tünteti ki bizalmával, akik 2002-ben még az AK Parti támogatóinak számítottak. Ez egyébként jól mutatja, hogy a 2000-es évekre a muszlim testvéri közösségek egyre komolyabb politikai mozgósító erővel is bírnak. 
Az 1980-as években több, a politikai centrumtól kissé távolabb álló politikai párt is létesült. Közülük említésre méltó a Demokratikus Baloldali Párt (Demokratik Sol Partisi, DSP), melyet az 1999-es baloldali fordulat hatalomra is juttatott. A DBP elhibázott gazdaságpolitikája azonban elszegényítette - a török lakosságot, és nagyban hozzájárult ahhoz, hogy a párt bukása után az AK Parti jusson hatalomra, amely gazdasági fordulatot ígért. A másik feltörekvő párt a Jólét Pártja (Refah Partisi): a markánsan jobboldali, radikálisabb ideológiát képviselő, az 1990es évek végén a miniszterelnöki tisztséget is betöltő Necmettin Erbakan nevéhez köthető párt az úgynevezett nemzeti víziót, a milli görüş-t szándékozott megvalósítani, a párt az 1970-es évek MSP-je örököseként is értelmezhetö. Miután a Refahot 1998-ban betiltották arra hivatkozva, hogy tevékenysége ellentétes a köztársaság világi jellegével, a párt politikusai létrehozták a 2001-ig élő Erény Pártját (Fazilet Partisi, FP). Míg 2001-ben a baloldali Bülent Ecevit kormányának népszerüségvesztését követően a Fazilet egyes politikusai az újonnan alakult AK Partihoz csatlakoztak, addig a radikálisabbak ragaszkodva az erbakani eszmékhez új pártot alapítottak Boldogság Pártja (Saadet Partisi, SP) néven, ami ma is a legfontosabb parlamenten kívüli politikai erő, s komoly támogatottsággal rendelkezik a nyugati emigráció töröksége körében.

\subsubsection{A 2000-es évek pártrendszere}

Míg az 1983-as új párttörvény hatályba lépése után egy évtizedre viszonylag stabil volt a török pártrendszer, addig az 1990-es éveket a politikai és a gazdasági bizonytalanság jellemezte. A török választási rendszer különleges sajátossága a 10\%-os bejutási küszöb, valamint egy pártnak a rendkívüli népszerüsége tette lehetővé, hogy létrejöjjön a politikai egyensúly. A politikai egyensúly pedig hosszú távon a pártrendszer megcsontosodásához is vezetett.

A három legfőbb párt lényegében ugyanaz maradt a vizsgált időszakban. 2002 óta a dolgozatom tárgyát képező AK Parti kormányozza Törökországot. Az ellenzéki képviselők a kemalista CHP-hez, a nacionalisták az MHP-hez tartoznak, a kurd nemzetiségü képviselők egy része pedig függetlenként van jelen a nagy török nemzetgyülés, azaz a TBMM ülésein.

A 2009-ben meghirdetett kurd nyitás politikája a kurd politikai érdekképviselet kiszélesedését hozta, ami - véleményem szerint - a nagy pártok stabilitása után a legfontosabb pártpolitikai fejlemény a 2000-es években. A török nép a kurd kisebbséggel együtt képezi a rousseau-i értelemben vett népet, azaz a hatalom legitim forrását, ezért a kurd érdekek politikai képviseletének előbb-utóbb meg kellett jelennie a török politikai palettán. Ugyan az első nem- 
szeparatista kurd nacionalista erő, a Demokrácia Pártja (Demokrasi Partisi, DEP) már 1991ben hivatalosan is megalakulhatott, ez a gondolat politikai értelemben a 2000-es években vált népszerüvé. Az erősödést példázza az is, hogy a tematikát ma felvállaló Népek Demokratikus Pártja (Halkların Demokratik Partisi, HDP) már nem független jelölteket állított, hanem pártként mérettette meg magát a 2015-ös választásokon. Az észak-iraki kurdokkal való egyre inkább élénkülő diplomáciai kapcsolatok eredményeképpen 2014 végén már hivatalosan is bejegyeztek egy, a HDP-nél is radikálisabb politikai formációt, a törökországi székhelyü Kurdisztáni Függetlenségi Pártot (Kürdistan Özgürlük Partisi).

\subsection{Az AK Parti ideológiája, története és kormányzati müködése}

\subsubsection{Az AK Parti közvetlen előzménye: Menderes és Özal öröksége}

Az AK Parti az utóbbi évek domináns pártja, ezért részletesen is bemutatjuk a párt karakterét és történelmét. Az AK Parti mind ideológiai szempontból, mind pedig a politizálás mikéntje tekintetében több politikai hagyományt egyesít magában. A párt támogatói bázisa a közelmúlt török politikatörténetének több jelentős személyiségével is könnyen tud azonosulni. Így referenciának tekinti a kivégzett miniszterelnököt, a tízévnyi kormányzás után a puccsisták által kivégzett Adnan Menderest, valamint az 1980-as évek és az 1990-es évek elejének stabilitást hozó Turgut Özalt. (A szellemiségbeli rokon vonást megerősíti, hogy a közösségi oldalakon a török kormánypárt hívei gyakran tesznek közzé olyan bejegyzéseket, amelyeken ezt a két jelentős államférfit Recep Tayyip Erdoğannal hasonlítják össze. Ugyanezt az üzenetet az AK Parti más hívei egy kicsit radikálisabb formában fogalmazzák meg. Ök azt állítják, hogy míg Menderest felkötötték, Özalt pedig megmérgezték, viszont Erdoğant nem hagyják bántani.

Menderes és Özal abban a tekintetben számít Erdoğan előképének, hogy hittek abban, hogy a részvételen alapuló demokráciát ki kell szélesíteni, a szegényebb néprétegeket is be kell vonni a társadalompolitika alakításába, valamint jóléti intézkedésekkel és infrastruktúrafejlesztéssel kell a szimpátiájukat elnyerni. Mint a bevezetőben láthattuk, Sartori elmélete szerint fontos a népet, annak sokszínü értelmezése mellett, a lehető legtöbb szinten megnyerni az aktuális politikai céloknak. Mindezen célok eléréséhez Nyugat-barát politikát és a külföldi müködő tőke bevonásán alapuló szociális piacgazdaságot igyekeztek teremteni. Mindhárom politikus esetében markáns elem az iszlám valláshoz való erős kötődés, ám mindhármuk megpróbálta hitét összeegyeztetni az atatürki szekularizáció elvével. Míg az első kettő politikusnak komoly ellenlábasa volt e téren a katonaság, addig Erdoğan - mint azt később látni fogjuk - sikeresen demilitarizálta Törökország politikai életét, és a hadsereg föparancsnokságának 2007-es 
kritikus sajtónyilatkozata sem volt képes visszafordítani az időt, az elégedetlen, a világi értékekhez ragaszkodó tisztek nem tudták eltávolítani a hatalomból.

\subsubsection{Az AK Parti közvetlen előzménye: Erbakan öröksége}

Menderes és Özal mellett egy kissé radikálisabb vezető, a rövid ideig miniszterelnöki tisztséget is betöltő Necmettin Erbakan és az általa megtestesített vallásosabb vonal is integráns része az AK Parti örökségének. Ez az irány eleinte a klasszikus konzervatív politika alternatívájaként jelent meg, majd elveinek egy része beépült a konzervatívok programjába, ma pedig újfent önálló, bár kevés befolyással bíró politikai alternatívaként van jelen a Boldogság Pártja (Saadet Partisi, SP) a török közéletben.

A 1970-es években megjelenő, a liberális-populista jobboldalnak konkurenciát jelentő politikai erő Necmettin Erbakan személyében már az elején egy karizmatikus vezetőt tudhatott maga mögött. Erbakan és a körülötte kikristályosodó mozgalom már joggal nevezhető (mérsékelt) iszlamistának. Az 1969-ben a közép-anatóliai Konyában függetlenként megválasztott, a Demirelhez hasonlóan gépészmérnöki végzettségü Erbakan társaival 1970-ben létrehozza a Nemzeti Rendpártot (Milli Nizam Partisi, MNP), amit az AK Parti első direkt előképének, elődjének tekinthetünk. A párt nem lett hosszú életü, hiszen már 1971-ben betiltotta az alkotmánybíróság arra hivatkozva, hogy a programja ellentétes a török állam világi jellegével. A párt egyik képviselője, Süleyman Arif Emre ezek után életre hívta a Nemzeti Megbékélési Pártot (Milli Selamet Partisi, MSP), ami már Erbakan vezetése alatt az 1973-as választásokon a szavazatok 11\%-át gyüjtötte be. 1974-ben az MSP váratlanul koalícióra lépett a felfelé ívelő időszakát élő CHP-vel, Erbakanból pedig egyszer csak miniszterelnök-helyettes lett. Ez persze nem akadályozta meg az MSP-t abban, hogy 1975-től kezdve Demirel jobboldali nacionalista kormányában is részt vegyen. Ennek a koalíciós időszaknak a török történelem harmadik puccsa vetett véget 1980-ban.

Egy ideig nem müködhettek politikai tömörülések Törökországban. 1983-ban a „milli görüş”, a nemzeti vízió nevü ideológiai alapra támaszkodva Erbakan megalapította a Jólét Pártját (Refah Partisi, RP), amelyet a szekularizáció elleni támadással vádoltak, és 1997-ben betiltottak. Ezt követően Erbakan követői az Erény Pártját (Fazilet Partisi, FP) hívták életre, mely 2001-ig létezett. Annak megszünése után a máig müködő Boldogság Pártja (Saadet Partisi, SP) vette át az erbakanista tábor képviseletének szerepét.

A nemzeti vízió egy olyan politikai program, amely szerint a kamatmentes bank- és pénzrendszer teremti meg a gazdasági igazságosságot, a kamatmentes állami hitelekből 
müködő szövetkezetek valódi termelést folytatnak, és nem a pénz válik árucikké. Az iszlám vallás a kamatot súlyos bünnek tekinti, a vallásos eszkatológia szerint a kamat az utolsó időkben szinte megkerülhetetlen lesz, de a hívő feladata, hogy minél inkább távol maradjon attól. Mohamed próféta Bukhari imám által lejegyzett mondása szerint “a végső időkben szinte mindenki a kamatból fog élni, aki nem, arra is rákerül a kamat pora." (BUKHARI, 8. kötet, 74. fejezet, 265. hadísz)

A kamatmentesség mellett a nemzeti vízió másik gazdasági alapvetése az ún. valós gazdaság támogatása. Ezalatt azt értették, hogy a nemzetgazdaság alapját a szövetkezeteknek kell képezniük, illetve a telepítő tényezők közül a kooperációt kell előnyben részesíteni. A milli görüș számára az emberi jogok is kiemelt fontosságúak: az alapvető jogok, mint az élethez-, a vagyonhoz-, illetve a személyes biztonsághoz való jog mellett az utazás, a munka- és szakmaválasztás szabadságán keresztül szerették volna elérni azt, hogy az emberek boldogok legyenek. A nemzeti vízió tehát nem csupán egy iszlám ihlette gazdasági és politikai program, hanem az ember természetéből kiinduló, tradicionális rendszer, melynek a központi eleme a boldogság, amit a muszlim ember egyszerre értékel evilági és túlvilági örömként is. Ez magyarázza, hogy az Erbakan által alapított utolsó, máig is létező párt neve Saadet, azaz Boldogság Párt.

A nemzeti vízió az első példa arra a török politikai életben, hogy egymásra talál egy misztikus vallási csoport és egy pártpolitikai erő. A misztikus csoport a naksibendi szúfi tarikák hálózata volt. A naksibendik müködését a többi testvériséghez hasonlóan betiltották a köztársaság kezdeti korszakában, de a felszín alatt ezek tovább éltek. Az 1950-es években tarthatták első nyilvános összejöveteleiket, az 1970-es évektől kezdve pedig egyre nyilvánvalóbb alakítói lettek a vallásos tömegek társadalmi, majd politikai gondolkodásának. (YAVUZ, 2005, 17) A szúfi tarikák egyik legfontosabb tanítása a spirituális tisztaság megőrzésének fontossága. A milli görüş programpontjai is épp azt célozzák, hogy a hívő egyén tiszta lelkiismerettel tudjon részt venni a tágabb közösség, a köztársaság életében.

\subsubsection{Megalakul az AK Parti}

A különböző konzervatív és mérsékelt iszlamista gyökerekböl, a menderesi, az özali és az erbakani örökségből táplálkozó, az elveik miatt a börtönt is gyakran megtapasztaló politikusok Recep Tayyip Erdoğan vezetésével 2001-ben hozták létre az AK Partit. A párt színévé a narancssárgát, jelképévé a fényt hozó izzót választották. A szimbolikus politizálásra 
oly hajlamos Törökországban nagyon találó jelkép ez, hiszen egyszerre utal a technikaiinfrastrukturális fejlesztés szükségességére és a felvilágosítás, az oktatás fontosságára, de egyben diszkréten vallási üzenetet is hordoz, tudniillik a fény az iszlám vallásban is kiemelten fontos jelenség.

A 2002-es választásokra készített „Her şey Türkiye için”, azaz „Mindent Törökországért” címet viselő program üzenete az volt, hogy az AK Parti a civil társadalom megerősítésén keresztül radikális államreformra törekszik. A gazdasági fejlődést szorosan összekötötték a demokratikus jogok érvényesülésével, azaz csak úgy tartották elképzelhetőnek az előbbit, ha már az utóbbi garantált. Egy, a demokratikus rendszerekben megszokott, a hatalmi ágak szétválasztásán alapuló szisztémában hittek. Főleg a bírósági rendszer függetlenségének garantálását kívánták elérni. Az államreform területén kiemelendő a decentralizálás, az e-kormányzás bevezetése és a helyhatóságok megerősítése. Ezek a gondolatok mindenképpen modernnek és progresszívnak nevezhetőek, különösképpen az, hogy az internetet és a modern infokommunikációs technológiákat is beemelni szándékoztak az ország vezetésébe. A párt gazdaságpolitikája részben a milli görüş-böl megismert elveket tartalmazza, igyekszik visszaszorítani a kamatos pénzrendszert, ugyanakkor - tanulva a DP és az AP hibáiból - célként nevezik meg az infláció elleni küzdelmet. Az exportorientált gazdaságpolitika is megjelent a programban: a kivitelt kívánták erősíteni a külföldi behozatallal, beleértve a külföldi tőkebehozatallal szemben. A vidékfejlesztés is háttérbe szorult. Ennek több oka is van: az európai integráció, a posztindusztriális gazdasági szerkezet óhatatlanul háttérbe szorítja a mezőgazdaságot. Bár még mindig milliók dolgoznak a primer szektorban, egyre többen térnek át a szolgáltatásokra, azon belül is a turizmus kap kiemelt szerepet. A prioritások közé ekkor kerül be a közlekedési infrastruktúra fejlesztése és az olcsó és biztonságos energiaellátás. A gazdasági liberalizációhoz való erős ragaszkodás nem kerüli el a nyugati elemzők figyelmét sem, így Evangelista Axiarlis is elismeri, hogy ,az AKP sok politikai döntése, inkább liberális inspirációjú, minthogy iszlamista lenne”. (AXIARLIS, 2014, 5)

A fent vázolt kampányprogramot megalkotó AK Parti hatalmas dinamizmussal kezdett hozzá Erdoğan és nézetei népszerüsítéséhez. A megalakulásuk utáni első 45 nap során 53 tömeggyülést tartottak országszerte. Erdal Alkış „hangtalan menetelésnek” nevezi ezt az erőfeszítést. (ALKIS, 2013) A hangtalan menetelés nagyban hozzájárult az AK Parti támogatottságának megszilárdulásához, és ahhoz hogy a 2002. november 3-ai nemzetgyülési választásokon megszerezze a voksok 34,28\%-át és a képviselői helyek kétharmadát annak köszönhetően, hogy a 10\%-os bejutási küszöb miatt a hat független honatya mellett csak két párt képviselői kaptak helyet az ankarai Nagy Török Nemzetgyülésben (TBMM), az AK Parti 
és a Köztársasági Néppárt. A sikerben továbbá olyan tényezők is szerepet játszottak, mint az országot sújtó 2001-es gazdasági válság, ami az előző kormánykoalíció számlájára írtak a választók, illetve a szintén a hatalmon lévőkhöz köthető korrupciós botrányok. Ezek tükrében valóban hitelesnek tünt a frissen megalapított AK Parti, amely sok ellenszavazatot kapott.

\subsubsection{Inasévek}

Az AK Parti és az általa jelölt három kormány vezetője, Recep Tayyip Erdoğan, a munka világából vett hasonlattal inas-, tanonc-, és mesterkorszakoknak nevezte a három választás (2002, 2007 és 2011) utáni időszakokat, hiszen ez a kép jól mutatja, hogy egy párt is olyan fokozatosan sajátítja el a kormányzás mesterségét, mint egy kézműves. Az alábbi táblázatokon láthatjuk, hogy az AK Partira adott szavazatok hogyan változtak az elmúlt négy parlamenti választáson.

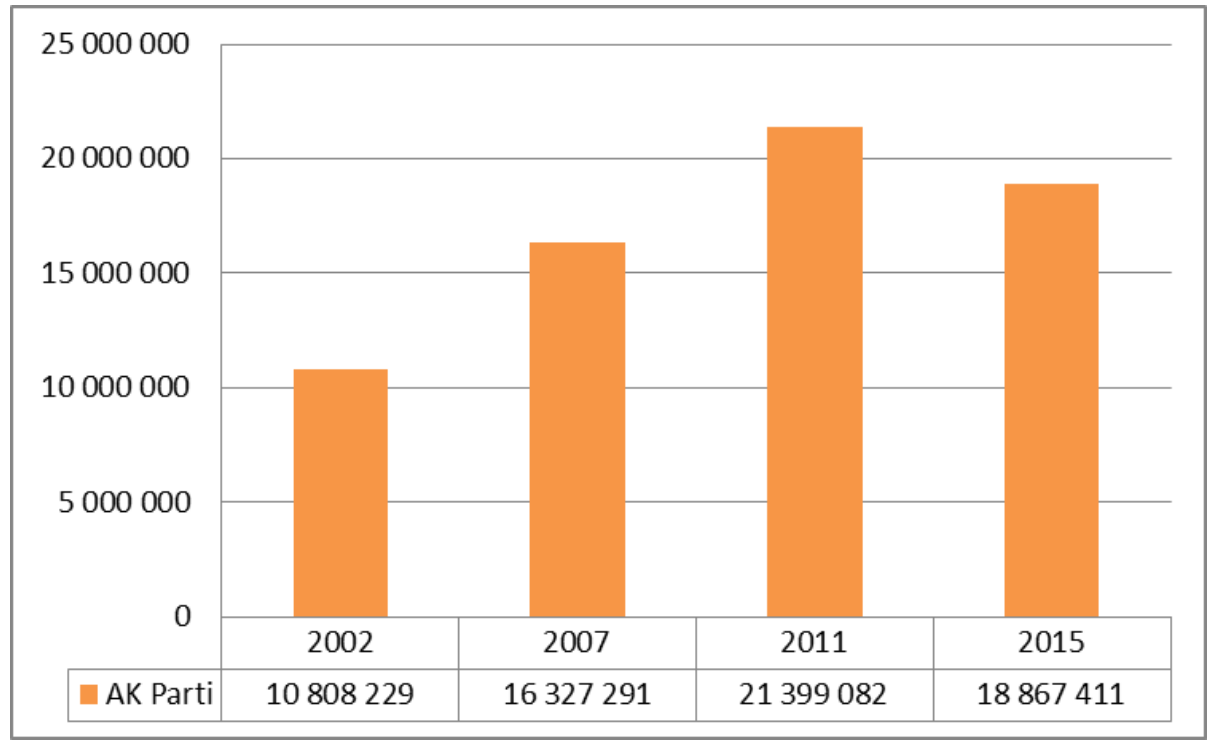

1. diagram. Az AK Partira leadott szavazatok számának változása. 


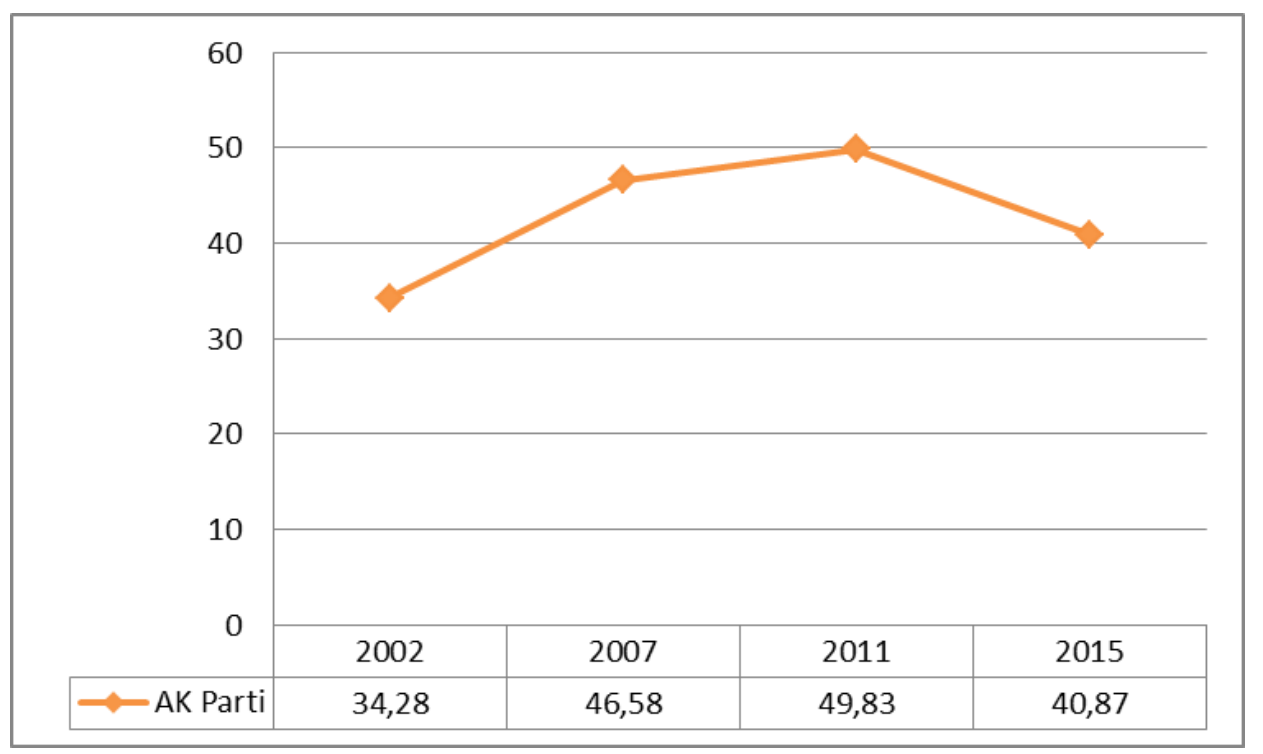

2. diagram. Az AK Parti parlamenti választáson kapott szavazatainak aránya

Bár az AK Partit és a 2002 óta tartó kormányzást rendszerint Erdoğan nevéhez kötjük, de az első kormányukat, a Török Köztársaság történetének 58. kabinetét nem ö, hanem a későbbi köztársasági elnök, Abdullah Gül vezette, Erdoğan 2003 márciusában vette csak át a stafétabotot. Ennek az volt az oka, hogy Erdoğan politikai véleménynyilvánítása miatt börtönben ült, és szabadulása után is egy ideig el volt tiltva a közügyek gyakorlásától. A délkelet-törökországi Siirtben rendezett idöközi választásokon szerzett parlamenti mandátumot, így a kormányrudat átvehette Abdullah Gültől.

A kormányt átstrukturáló, a miniszterek számát csökkentő, így a közigazgatás költségein is spóroló, Erdoğan-vezette 59. török kormány komoly ellenféllel találta szemben magát. Nem csupán azzal kellett megküzdenie, hogy a 90-es évek hiperinflációja képletesen, az 1999-es nagy földrengés pedig ténylegesen is romba döntötte az országot, hanem a kormányzás erős fékeként állt velük szemben Ahmet Necdet Sezer államfó, aki a két fenti kormány törvényjavaslatai közül 17-et visszautasított. A főleg ceremoniális szerepkörökkel bíró, ám az ancien régime-hez, a régi rendhez erősen kötődő jogász a mindennapi politika aktív szereplöje lett. Sezer, aki azelőtt a jelentős hatalommal felruházott alkotmánybíróság elnöke volt, annak ellenére, hogy öt párt jelöltjeként került a köztársasági elnöki székbe, már az AK Parti győzelme előtt sem bírta a teljes politikai elit támogatását, hiszen a TBMM is csak másodjára szavazta meg kinevezését. Hivatalosan soha nem tartozott egyetlen párthoz sem, de az AK Partival többször is konfrontálódott. 
Az AK Parti ebben az „inas-időszakban” erősödő párt képét mutatta. 2003-ban Çorum városában megnyertek egy időközi önkormányzati választást, ezzel először adtak polgármestert az országban. A 2004-es helyhatósági választás ezen a téren is áttörést jelentett a párt számára. A szavazatok 41,67\%-át szerezték meg, 1950 település, köztük a 15 megyei jogú városból 11 polgármestere lett „narancsszínü”.

Az inaskorszakban lévő, ám egyre magabiztosabb, ezért a vallásos néptömegek lelki igényei felé is nyitó AK Partit és kormányát 2007. április 27-én újabb kihívás érte. A török hadsereg honlapján közlemény jelent meg, melyben az állam szekuláris volta elleni támadásként értékelt néhány eseményt. Említést tesznek arról, hogy csak külső nyomásra álltak el a szervezők egy az iszlám szent könyvéből, a Kegyes Koránból való felolvasóest megrendezésétől, ami egybeesett az atatürki időkben bevezetett nemzeti függetlenségi- és gyermekünneppel, illetve hogy az ünnep előestéjén egyes vidéki városokban kislányok tradicionális öltözetben vallásos énekeket énekeltek. Továbbá azt nehezményezték, hogy Ankara egyik kerületében minden iskolaigazgatót köteleztek egy olyan programon való részvételre, melyen Mohamed próféta születéséről emlékeztek meg. Yaşar Büyükanıt vezérkari főnök ezeket a helyi jelentőségü rendezvényeket a köztársaságra veszélyesnek ítélte, azonban az igazi „fenyegetést” az államfőválasztás apropója szolgáltatta. Közleményben azt is megjegyezték, hogy szorosan nyomon követik, hogy kit is választ a TBMM Ahmet Necdet Sezer helyére. A török politikai közvéleményt sokkolta a közlemény. A nyilatkozatot azonban nem követte katonai lépés, a szöveget 2011-ben pedig el is távolították a hadsereg honlapjáról. A katonaság meghátrálását több tényezővel is magyarázzák, Ümit Cizre Sakallığlu szerint a legföbb ok az lehet, hogy az AK Parti reformjai az euroatlanti integrációban gyökereznek, ami ellen még a vezérkari fönök sem mer fellépni. (SAKALLIOGLU, 2008, 12) A 2007-es év során a hadsereg ún. „e-memorandumos” puccskísérletéből megerősödve jött ki az AK Parti. 12 százalékkal több szavazatot szerzett a párt az elörehozott parlamenti választásokon (46\%), s sikerült a nemzetgyülésben Abdullah Gült megválasztania köztársasági elnöknek 339 szavazattal. Megkezdődhetett a „tanonckorszak”.

\subsubsection{Tanoncévek}

A tanonckorszakban az addig szárnyaló török gazdaságnak szembe kellett néznie a 2008-2009es globális pénzügyi és gazdasági válsággal. A bruttó hazai össztermék (GDP) a 2002-es 232,5 milliárd dollárról 2008-ra 730,3-ra nőtt, ám 2009-ben 115 milliárdos csökkenést volt kénytelen elkönyvelni a török gazdaság. (COUNTRY ECONOMY, 2002) A hat év alatt (2002 és 2008 
között) megháromszorozódó bevétel előbb megcsappant, majd 2010-től újra nőni kezdett, s a török gazdaság növekedési üteme képes volt megközelíteni a 10\%-ot is. Ebben jelentős szerepet játszott az, hogy a török bankrendszert nem ingatta meg a válság, illetve fokozódtak az állami infrastrukturális beruházások, amelyek élénkítőleg hatottak a gazdaságra. Így bár 2009-ben felvetődött, hogy az IMF-től kérjen a kormány segítséget, erre nem volt szükség, sőt 2013-ban vissza is fizették a korábbi IMF-kölcsönöket.

A tanoncévek során az AK Parti nekilátott a politikai intézményrendszer reformjának is. Ennek talán legfontosabb eleme a 2007-es alkotmányreform, amit novemberben egy népszavazás is megerösített. A változtatások értelmében ezentúl a nép választhatta meg a köztársasági elnököt, míg a parlamenti képviselők mandátuma ötről négy évre csökkent. Ez a módosítás garancia volt arra, hogy a nép szélesebb körben beleszólhatott sorsa alakításába.

A tanonckorszak elején ugyanakkor politikai értelemben két komoly kihívással is szembetalálta magát az AK Parti. 2008-ban vált nyilvánossá az ún. Ergenekon-ügy. A puccsoktól mindig is tartó török közvélemény aggodalommal vette tudomásul, hogy egy ultranacionalista, katonatisztekböl és értelmiségiekből álló csoport a legitim módon megválasztott kormány hatalmának megdöntésére tört. Isztambulban 2012 áprilisában megkezdődött fő Ergenekon-per során összesen 274 személyt vádoltak meg, hogy fegyveres terrorszervezetet igyekeztek létrehozni azzal a céllal, hogy megdöntsék a törvényes török kormányt, és az állam vezetését hazafias katonatisztek kezébe játsszák át. A szervezkedés számos vezetőjét, így İlker Başbuğ volt vezérkari főnököt életfogytiglani börtönbüntetésre ítélték.

A másik eset nem a kormányt, hanem magát a kormánypártot érintette, mikor 2008. március 14-én Abdurrahman Yalçınkaya, a Legfelsőbb Bíróság föügyésze javaslatot tett az AK Parti betiltására. Nem meglepő módon megint a szekuláris államrend elleni lépésekkel vádolták meg a muszlim értékrendet valló pártot, mint szellemi elődeit: a Demokrata Pártot, a Nemzeti Rendpártot és a többi jobboldali formációt is. A kereset a párt betiltásán túl 71 vezető személyiséget szeretett volna öt évre eltiltani a politizálástól, így járt volna Recep Tayyip Erdoğan miniszterelnök és Abdullah Gül köztársasági elnök is. Számos vádat fogalmazott meg a föügyész, melyek között megint elökerült a fejkendö-ügy. A parlament 2008 februárjában olyan törvényt fogadott el, hogy a felsőoktatásban lehetővé vált a fejkendő viselése, amelyet a kemalista csoportok nem tudtak elfogadni.

A fejkendő persze csak jelkép. Egyrészt politikai jelkép azok számára, akik annak köztéri viselését ellenzik, másrészt ugyanazok azt gondolják, hogy a fejkendőnek önmagán túlmutató jelentősége is van. A párt feloszlatását célzó perben is elhangzott, hogy az AK Parti valójában 
az iszlám jogrend, a saría bevezetésére törekszik, élve az iszlám jogból ismert eszközzel, a takíjjával, a rejtőzködéssel, azaz „elkendőzi” valódi szándékát.

A párt betiltásának ügye nem egyszerüen egy párt betiltásának ügye volt, hanem az egész pártrendszer későbbi alakulására is komoly hatással volt. A betiltási kísérlet mögött hatalomtechnikai okok is álltak. A két választást egymás után megnyerő AK Parti egy időre felszámolta a politikai váltógazdálkodást, háttérbe szorította az ellenzéket. Mivel 47 képviselői hellyel több jutott nekik, mint a többi pártnak összesen, saját akaratát könnyü szerrel rá tudta erőltetni a parlamentre, ezzel lecsökkent a politikai viták esélye és jelentősége, valamint lehetőség nyílt arra, hogy az AK Parti a törökök életének nagyobb szeletét ellenörizze. A per kezdeményezői ezen a „status quo”-n szerettek volna változtatni, ám az AK Parti hegemóniáját nem sikerült megtörni, végül az AK Partit nem tiltották be, csupán megvonták állami támogatásainak egy részét, illetve elkobozták a pártvagyon felét.

A betiltási per ellenére a kormánypárt megőrizte pozícióit. Sőt a 2011-es nemzetgyülési választásokon már majdnem minden második választó Erdoğanékra voksolt. A szavazatok 49,83\%-át megszerezve nekikezdhettek a mesterévekhez. Ahogy arra a teljes választási rendszert és az eredményeket is behatóan elemző Egeresi Zoltán rámutat „az eredmény mást is jelez: az AK Parti a török szavazókat sikeresen győzte meg politikájának helyességéről. S valóban: az elmúlt 9 évben Törökország páratlan gazdasági fejlődésen ment keresztül”. (EGERESI, 2011, 4)

\subsubsection{Mesterévek}

A 2011-es választásokat követően az AK Parti tovább bővítette befolyását azzal, hogy egyesült egy frissen alakult, mérsékelt iszlamista formációval, a Numan Kurtulmuş vezette, a társadalmi igazságosságot zászlójára tűző Nép Hangja Párttal (Halkın Sesi Partisi). Az AK Parti további erősödése helyett ezután a párt lassú eróziójának jelei kezdtek mutatkozni, ugyanakkor az is látszott, hogy a pártvezetés összezár, és mindent megtesz ennek elkerülésére.

A 2013-as év során egyértelművé vált, hogy az AK Parti reformjai egyre több érdeket sértenek. Az érdeksérelmet szenvedők között találjuk azokat a társadalmi csoportokat, melyek kiszorultak a hatalomból, itt elsősorban a baloldali és kemalista meggyőződésű rétegekre kell gondolni, de nem szabad megfelejtkezni a párt „belső ellenzékéről” sem.

A 2013 májusa és augusztusa között az isztambuli Sétatérről, a híres-hírhedt Gezi Parkból kiinduló, a fák kivágását ellenző civil tüntetés országos tiltakozási hullámmá terebélyesedett, helyenként zavargássá alakult át. A tüntetéssorozatot viszonylag gyorsan kezelni tudta a török 
kormány, s egy hónap alatt megszűnt az ország nagyobb városaiban kibontakozó zavargássorozat. A közvélemény-kutatások kimutatták, hogy ezekben főleg baloldali pártokkal és eszmékkel szimpatizáló fiatalok vonultak a közterekre. A gyors, ugyanakkor sokat bírált fellépés révén nőtt az országban a polarizáció: azok, akik eddig sem szimpatizáltak az AK Partival, ezzel még távolabb kerültek tőle, míg a saját támogatói körében az csupán minimális népszerüségvesztéssel járt. Ezt a 2013 júniusában rendezett tömegrendezvényekkel is sikeressel demonstrálta a párt.

Az év utolsó hónapjának eseményei a Gezi parki eseményeknél sokkal jobban megrengették a szavazói bázis egy részének bizalmát. December 16-án a legendás futballcsillag, az AK Parti isztambuli képviselője, Hakan Şükür jelentette be, hogy kilép a párt frakciójából és függetlenként folytatja képviselői munkáját. Indoklásában a derszhánékra és egy bizonyos hodzsaefendire hivatkozott. A hodzsaefendi nem más, mint az amerikai száműzetésben élő idős hitszónok, Fethullah Gülen, aki- bár a közvélemény eddig a kormánypárt holdudvarához sorolta- egyre kritikusabban nyilatkozott a kormányról. Gülen, a kelet-anatóliai Erzurumban született, s a nagy hatású, de ellentmondásos vallási vezető mozgalmának központi gondolata a hizmet, azaz a közösség és tágabb társadalom segítése, szolgálata. A nagy kérdés, ami a mozgalom és a kormány közötti nézeteltérések kapcsán felvetődik Ömer Ünalan szerint épp az, hogy a hizmet teljesítéséhez szükség van-e politikai részvételre, azaz lehet-e, kell-e a kormányt támogatnia egy alapvetően vallási csoportnak, illetve a szekuláris államot vezető kormánynak szabad-e ezen testvéri közösségek közeledését elfogadnia. (ÜNALAN, 2012) A sajtó tudni vélte, hogy akár 70 képviselő is követheti Şükürt, de mindössze négyen tették meg ezt a lépést, ezzel az AK- Parti frakciója és a kormánytöbbség stabilan megmaradt. (HÜR HABER) A Hakan Şükür kilépését követő nap sem telt eseménytelenül. December 17-én korrupció vádjával 71 személyt, köztük három miniszter fiát és a kormánypárthoz köthető vezető üzletembereket állítottak elő. Később több minisztert és politikust, sőt a miniszterelnök fiát, Bilal Erdoğant is megvádolták, ugyanakkor február végére minden érintettet szabadlábra helyeztek. A letartóztatási hullám komoly gazdasági károkat okozott a török vállalkozóknak, a tőzsde is „beárazta” az esetet. Természetes módon az AK Partira is kihatott az ügy, hiszen egyesek szemében elvesztette „akságát”, azaz tisztaságát azzal, hogy a korrupció vádja érte.

A belső politikai konfliktusok, korrupciós botrány - 2014 februárjában már maga a miniszterelnök is botrányba keveredett, az ún. „kiszivárogtatási” ügy kapcsán - ennek ellenére az AK Parti képes volt megőrizni stabilitását és hatalmát. A megszellőztetett, kétes hitelességü hangfelvételek szerint Recep Tayyip Erdoğan arról beszélt 33 éves Bilal nevü fiával, hogy 
rejtsen el egy nagyobb összeget a lakásában, miközben az ellenzék az apját korrupcióval vádolta, és lemondásra szólította fel. Erdoğan az internetre felkerült anyagot tiszta hazugságnak és hamisítványnak nevezte, pozícióját pedig megtartotta. (THE GUARDIAN, 2014) Azt, hogy Erdoğan politikai értelemben helyzetét megszilárdította, az is bizonyítja, hogy a 2014 márciusában tartott helyhatósági választás, ahol továbbra is a legtöbb szavazatot tudta megszerezni. Az első közvetlen elnökválasztást pedig Recep Tayyip Erdoğan magabiztosan, már az első fordulóban megnyerte. Ebben több tényező is közrejátszott, azonban ki kell emelni, hogy a gazdasági és politikai stabilitás, amit az AK Parti az utóbbi 13 évben megteremtett, jelentős súllyal esett latba. (EGERESI, 2014)

Egy másik lehetséges interpretáció szerint nem az AK Parti egésze volt képes a rendszer stabilizálására, hanem személyesen Recep Tayyip Erdoğan miniszterelnök, majd köztársasági elnök volt az, aki személyes befolyását növelte, kiépítette személyes támogatóinak körét és a saját politikai céljai érdekében sikeres válságmenedzselést végzett, így képes volt azokat a krízishelyzeteket társadalmi szinten kezelni, mely hatalmát veszélyeztette. Ide sorolhatjuk a korrupciós vádak kezelését, de a 2016. július 15-i puccskísérletre adott válaszokat. Ezen politikai előnye az lett, hogy egyértelmüen kiderült, ki Erdoğan személyes ellensége azok közül, akik eddig így vagy úgy támogatták. Itt elsősorban Gülenre és mozgalmára gondolunk, beleértve Hakan Şükürt is. Erdoğan hatalomkoncentrációs törekvéseinek komoly hátulütöje viszont az lett, hogy számos „régi harcostársa” (pl. Abdullah Gül vagy Ahmet Davutoğlu) háttérbe szorult, elszigetelődött, vagy az elnök riválisává vált. Mindemellett Erdoğan az elbukott államcsínyt követően olyan szövetségesekkel vette magát körül, akik addig riválisai voltak. Az, hogy az ellenzéki MHP-vel és Devlet Bahçelivel fogott össze a „nemzet érdekében”, az AK Partin belül is sokakat meglephetett, ám mégsem az AK Parti szakadt ketté ebben a manőverben, hanem a MHP, azaz a nemzetiek gyengültek meg és nem Erdoğan irányvonala.

Végül feltétlenül szükséges megvilágítani, hogy milyen identitásúnak is kell tekinteni ezt a politikai formációt 13 év kormányzás után. Ahogy azt Egeresi Zoltán is megjegyzi, amíg ,az AK Parti egyfajta puha szekularizmust hirdet, amely lehetővé teszi az ember számára a vallás látványosabb megélését (akár a közintézményekben is), addig a szekulárisok annak teljes kizárását követelik.” (EGERESI, 2010, 13) A párt fejlődésének vizsgálata során is azt tapasztaltuk, hogy a világi államhoz való különleges viszonyulása adja egyediségét: szekuláris és demokrata, de a népi vallásosság igényeit is szem előtt tartó politikai erőről van szó. Ellentmondás érezhető itt a klasszikus és a muszlim világiság között, amelyet szükséges feloldani valahogy. A neokonzervativizmust kutató Özgün Erler nagyon jól összefoglalja egy mondatban, hogy lehet megtalálni az egyensúlyt a két oldal között, amikor azt írja: „az AKP 
tagjai szerint nem politikai identitásra van szükség, hanem identitásalapú politizálásra.” (ERLER, 2012, 130) Kahraman és Yener szerint (KAHRAMAN-YENER, 2007, 154) ez azt jelentené, hogy a kormánypárt az iszlám vallást politizálja át, annak talaján dolgoz ki egy új ideológiát. Az AK Parti tehát úgy lehet egyszerre muszlim és demokrata, hogy nem egy meglévő politikai ideológiai sémából indul ki, nem másolja az európai konzervativizmust, hanem a muszlim identitás mentén politizál, ami megjelenésében közel áll az európai konzervativizmushoz, tehát - ahogy azt Cemal Uysal is hangsúlyozza - az AK Parti nem egy ideológiai párt, hanem érték- és identitáskereső formáció. Az AK Parti a muszlim identitás melletti politizálása nem ellentétes a szekuláris állam melletti elkötelezettséggel. A politika azonban beemeli a vallást a saját terrénumába és megpróbálja feloldani azt a hagyományos - és hamis - dichotómiát, amely a vallásos-nem vallásos szavazók demokratikus és nemzeti elkötelezettsége között feszül. (UYSAL, 2008, 98)

\subsection{Az AK Parti demokratizálási lépései}

Az Igazságosság és Fejlődés Pártja egy több évtizede fennálló demokratikus rendszer terméke. A párt a betiltások, sokszor személyek elleni támadások során megtanulhatta, hogy a demokratikus jogállam micsoda védelmet nyújt egy párt müködéséhez. Demokratikus párt mind felépítésében és müködésében, mind abban a tekintetben, hogy mit vall a török társadalomról és annak jövőjéről. Egy ilyen demokratikus párt elemi érdeke, hogy a körülötte lévő környezet, a köztársaság intézményrendszere is demokratikus legyen, azaz átlátható legyen és biztosítsa a polgárok érdekeinek érvényesülését azáltal, hogy azok minél inkább beleszólhassanak sorsuk alakulásába. Ez az oka annak, hogy az AK Parti a demokratizálási folyamat aktív szereplője. Az AK Parti demokratizálási törekvéseit két szinten tudjuk különösen jól megragadni. Az egyik az európai integráció folyamata, a másik a 2007-es és a 2010-es alkotmányreform, illetve az az általa életre hívott struktúra, amiben felértékelődött a köztársasági elnök szerepe. (Ez utóbbi felveti azt az általánosabb kérdést, hogy a prezidenciális vagy parlamenti hatalomgyakorlás török kiadása milyen hatással lehet a demokratizálódásra.)

\subsubsection{Az uniós csatlakozási tárgyalások hatása a törvényhozásra és a demokratizálásra}

A demokratizálás és az Európai Unióhoz való csatlakozás előkészítése paradox viszonyt mutat Törökország esetében. Egyrészt az integráció előfeltétele, hogy az adott társadalom demokratikus legyen, és megfeleljen az európai müködés alapvető normáinak, valamint kész 
legyen betartani az európai rendszerek müködési elveit (pl. szubszidiaritás), illetve alkalmazni a már létező európai joganyagot (acquis communautaire). Másrészt Törökországban az Európai Unióra szokás modellként is tekinteni, olyan hatalmi pólusra, amelynek a mintái irányadóak a török közélet minden szereplöje számára. Azaz az EU-hoz való csatlakozás céljából demokratikusabbá kell tenni Törökországot, de Törökország demokratizálása csak akkor lehet sikeres és teljes, ha azt az Európai Unió - egyes törökországi szereplők akaratával szemben kikényszeríti.

Az uniós integráció a törökök számára több egy egyszerü gazdasági szükségszerüségnél, egyrészt identitáskeresésük része, másrészt pedig a stabilizáció fontos forrása. Az AK Parti politikusai és támogatói számára az Európai Unió egy demokratikus védőernyő, a szabadságjogok letéteményese. Itt elsősorban arra kell gondolni, hogy az európai országok saját polgáraik számára szavatolják a vallásgyakorlás szabadságát, és nincs olyan politikán kívüli tényező, amely beavatkozhatna a politikai rendszer ezen elemébe. Márpedig Törökországban ebben a tekintetben a katonaság a fék és az ellensúly szerepét tölti be, azaz a katonaság hosszú ideig korlátozni igyekezett a török muszlimok vallásgyakorlatát. Sok török muszlim úgy ítélte meg, hogy az Európai Unió ebben féken fogja tartani a török fegyveres erőket.

A következő fejezetben fogjuk tárgyalni, hogy EU-val való tárgyalásokkal párhuzamosan miként korlátozta az AK Parti kormánya a fegyveres erők mozgásterét, hogyan „demilitarizálta” Törökországot. Az Európa és Törökország között fennálló különbségek végül elvezetnek minket egy paradoxonhoz: az eddig euroszkeptikus, vallásos-konzervatív oldal elkezdi támogatni a csatlakozást, míg az eddig européernek tünő, keményvonalas kemalisták lesznek a legradikálisabb kritikusai az integrációnak. „A mai iszlamista körök azt kérik Európától, hogy kényszerítse rá Törökországot a koppenhágai kritériumok betartására” mondja erről a paradoxonról Burhanettin Duran, majd hozzáteszi, hogy a fenti politikai igény mögött nem csupán a vallásból fakadó követelések állnak, hanem az is, hogy egy új vállalkozói elit ezáltal szeretne lehetőségekhez és piachoz jutni. (DURAN, 2006, 295)

Az 1299-ben alakult Oszmán Birodalom ugyan Kis-Ázsiában kezdett először terjeszkedni, és első fővárosa, Bursa is ott található, csakhamar a Balkán vált központjává, illetve a két későbbi székhely, Edirne és Isztambul is európai földön fekszik. A mai európai hatalmi rendszer kialakulásakor az Oszmán Birodalom éppen hanyatló korszakát élte, kénytelen volt a középeurópai területeit feladva elhagyni a történelmi Magyarországot. Az 1699-es karlócai béke után, a vesztfáliai rendszerből egykor kimaradó törökök számára ezért elsősorban identitásbeli és nem gazdasági vagy politikai természetű kérdés az euroatlanti integráció. Törökországot az európai népekhez való tartozás motiválja. 
Ha Törökország számára identitásbeli kérdés az európai integráció, akkor arról sem szabad megfelejtkezni, hogy néhány tudati gátat is fel kell számolni ahhoz, hogy az sikeressé váljon. Davutoğlu egyértelművé teszi, hogy a törökök részéről ez a fékező erő az, hogy ,a függetlenségi háborút egyes európai szereplőkkel vívtuk meg, és ezért nem bízunk bennük”. (DAVUTOGLU, 2011, 283)

Európa részéről pedig egy nagy dilemma mutatkozik: a kérdés az, hogy az öreg kontinens kész-e egy muszlim többségű országot elfogadni az „egyre inkább befelé forduló keresztény klubba", ahogy az EU-ra Ali Babacan miniszterelnök-helyettes utalt 2011-ben.

Az AK Parti EU-integrációs politikája a külső szemlélő számára fordulatosnak tűnhet. A kormányzás első három évében nagy lendület volt megfigyelhető, ám 2005 után már egyre inkább úgy tünik, hogy kikerült a prioritások az uniós csatlakozás kérdése. A fent részletezett kettős tudati gát okozta egyensúlyozó diplomácia mind Európa, mind Törökország részéről úgy tünhet, hogy egyik sem igazán szeretné az integrációt. „Az AK Partitól érkező jelzések nagyon zavaróak” - jegyzi meg Meltem Müftüler-Baç. (ÖZDAL-DINCER-YENGIN, 2009, 205)

A hangsúlyeltolódás az AK Parti külügyi programját vizsgálva is feltünő. Az $\mathrm{AK}$ Parti 2002-es „Mindent Törökországért” címet viselő választási és kormányprogramjában mindössze három oldalt szentel a külpolitikának (AK PARTI, 2002, 91-93), mivel ekkor még nem a középhatalmi ambíciók mozgatták Erdoğanékat, hanem az előző kormány által hátrahagyott politikai és gazdasági válsághelyzet kezelése. Ebben a rövid szövegrészben található felsorolás szerint az első számú partner az Európai Unió és a NATO: „Törökország azon lesz, hogy mindent megtegyen azért, hogy a többi tagjelölt országtól is elvárt feltételeket azoknál hamarabb teljesítse". (AK PARTI, 2002, 92) A gazdasági és politikai együttmüködés mellett ekkor a közös európai védelmi stratégia megalkotásának igénye merül fel. Ne felejtsük el azonban, hogy alig egy évvel vagyunk a véres New York-i és washingtoni terrortámadások után, amikor a terrorizmus elleni küzdelem a nemzetközi diskurzus központi eleme volt!

A 2007-es programban már egy sokkal részletesebb külpolitikai alapvetést találunk, ám itt már egyre inkább háttérbe szorul az EU. Ezt magyarázhatjuk azzal is, hogy Törökország gyors fejlődésen ment keresztül, gazdaságilag és részben politikailag is megerősödött. Miután ekkor már egyértelmü volt az, hogy világpolitikai hatalmi szereplővé akar válni, az ország inkább saját integratív erejére figyelt, mint arra, hogy csatlakozzon egy olyan szervezethez, amely nem feltétlenül nyitott elötte. A szöveg az addig követett gyakorlattal kapcsolatban ezt írja „hittünk a sorsszerüségben és nem gondoltuk azt, hogy Törökország a saját külpolitikai útját járhatja.” (AK PARTI, 2007, 233) Elsősorban itt három külpolitikai témát emelnek ki: az EU-t, valamint Irak és Ciprus kérdését. Gyakorlati szempontból azonban az utóbbi is szorosan összefügg az 
elsővel. A lendület alábbhagyása abból is látszik a programban, hogy számos térséget az EU elé sorolnak. Így az első olyan integrációs lehetőség, amiről szót ejtenek, az a török-azeri-kazah együttmüködés, amiből későbbiekben kinőtt az ún. Türk Tanács. Amikor végül sor kerül az EU-ra, azt látjuk, hogy csupán egy oldal szól róla, és az is a globális és regionális béketeremtés miatt tekinti fontosnak a török-európai kapcsolatok szorosabbra füzését. Bár csatlakozási céldátumot nem jelöl meg az AK Parti, de összességében optimista a megfogalmazás, hiszen az integráció technikai feltételei adottak. Témám szempontjából fontos a következő megjegyzés is: „régebben, mivel Törökország még nem volt kellően felkészült és demokratikus, az Európai Unió megelőző bővítési periódusaiban fontos esélyt szalasztott el”. (AK PARTI, 2007, 245)

Az EU-hoz való hullámzó érzelmi viszonyulást jól példázza, hogy a 2011-es választási programban újfent kitüntetett helyre került az Európai Unió. A török kormánypárt hitet tesz amellett a dokumentumban, hogy újfent kiemelt célként kezeli a nyugati orientációt és az EUs csatlakozást. (AK PARTI, 2011) A stratégiai cél fontosságát pedig a dokumentum szerint 2002 óta változatlanul három dolog adja: 1. a demokratikus müködési formák kiszélesítése, 2. a kereskedelmi kapcsolatok erősítése, 3. az Európával már meglévő jó viszony további elmélyítése. Érdemes megjegyezni, hogy az AK Parti a teljes jogú tagság kérdését megfordítva azt is megjegyzi, hogy ha Európa netán elutasítaná Törökországot, akkor az öreg kontinens a 21. század egyik vesztese lenne, azaz az integráció nem csupán Törökország demokratizálása szempontjából kulcsfontosságú, hanem Európának is alapvető érdeke. Európa felől nézve ez a „,kölcsönös demokratizálás” az Európában élő törökök miatt lehet érdekes, az AK Parti éppen ezért kezeli kiemelten a Határon Túli Törökök és a Rokon Népek Hivatalának ezen a téren végzett munkáját.

Müftüler-Baç a fent már idézett írásában az AK Parti hullámzó EU-politikájával kapcsolatban egy, a párt hivatalos álláspontjától eltérő értelmezési lehetőségre is rávilágít. Érvelése szerint a „,szakítást” egy elvi különbség adja, mégpedig az EU és az AK Parti eltérő szabadságfelfogása. A szerző szerint az AK Parti számára az EU csupán eszköz, hogy az ott megszokott vallásszabadságot ,rákényszerítse” a szekuláris török hadseregre, azaz Európára hivatkozva lehessen a muszlimok jogait csorbító rendszert átalakítani. Ezen felfogás szerint pedig, ha már háttérbe szorult a katonaság, és a vallásgyakorlás is biztosított, akkor már nincs is szükség az Európai Unió védőernyőjére.

Az AK Parti, az Európai Unió és a demokrácia viszonyrendszerét vizsgálva lényeges megvizsgálni, hogy az Európai Unió és annak vezető politikusai miként tekintenek a pártra. Különösképpen azért izgalmas megközelítési lehetőség ez, hiszen a vizsgált időszakban egyszer a párt léte is kockán forgott, mikor is az ügyészség annak betiltását indítványozta. A világ 
demokráciáiban egyedülálló dolog, hogy alkotmányellenesnek bélyegezzenek meg, és megkíséreljenek betiltani egy már több éve kormányon lévő politikai erőt. A rendkívüli helyzet Olli Rehn uniós biztost is meglepte, megütközésének így adott hangot: „,normális európai demokráciákban a politikai vitákat a parlamentben folytatják le, a szavazóurnáknál és nem a bíróságon dől el a politikai vezetés sorsa.” (ÖZCAN-ELMAS-KUTLAY-MUTUS, 2009, 116) A török Alkotmánybíróság végül „,pénzbüntetésre” ítélte az AK Partit, azaz megvonták tőle féléves állami támogatását, de a párt müködését nem függesztették fel. Az EU törökbarát szereplői, így Joost Langendijk, az európai-török parlamentközi bizottság társelnöke is jelezte, hogy a török demokrácia védelmében fel kell gyorsítani a csatlakozási folyamatot.

Az AK Parti esete is megmutatta, ahogy az a szakirodalomból is világosság válik, hogy a parlamentáris demokrácia építése nem csak egyirányú folyamat lehet. Kétségtelen, hogy az unió, mint demokratizáló „,inger”, külső húzóerő komoly szerepet játszik a demokratikus értékek meggyökereztetésében.

Az AK Parti a vallásszabadság biztosításához keres tehát hátteret az unióban, egyben egy szekuláris közösséghez kíván csatlakozni. A vallásszabadság kiterjesztése és a hadsereg szekularizmusa vagy épp túlhatalma elleni fellépés a szekuláris Európára hivatkozva teljesülne be.

Ismert példa az európaizációs hatás, a demokrácia konszolidációjában mind a mediterrán mind a keleti bővítés esetében. Jelentős különbség viszont egyes országok tekintetében az, hogy az adott ország milyen demokratikus hagyományokkal rendelkezik, politikai kultúrájában tude valamiféle demokratikus ethoszhoz visszatérni.

\subsubsection{Az alkotmánymódosító népszavazások hatása a demokratizálásra}

Egyetérthetünk Olli Rehn uniós biztossal, hogy nem természetes az, ha nem a nép dönt egy amúgy népszerü kormánypárt sorsáról, hanem az alkotmánybíróság. Ahhoz, hogy ez ne ismétlődhessen meg, illetve ebben a tekintetben is biztonság és stabilitás legyen Törökországban, egyértelművé vált egy alkotmányreform szükségessége, amit mind 2007-ben, mind pedig 2010-ben egy-egy népszavazás szentesített. Alapvető probléma az alkotmánybíróság politikai szerepvállalása, ami azt jelenti, hogy a testület nem az alkotmányos rend védelmezőjének szerepét tölti be csupán, hanem mintegy politikai harcok szereplőjévé avanzsál.

2007-ben Törökország Özbudun és Gençkaya szerint alkotmányos válságot élt át. A válság szó alatt azt értik a szerzők, hogy a köztársasági elnök megválasztási módjának megváltoztatása 
nem volt lehetséges az akkori alkotmányos keretek között. Az inkább a kemalistákkal szimpatizáló Necdet Sezer köztársasági elnök nem írta alá az ezt célzó törvénymódosítást, és figyelmeztetett, hogy az így létrejövő rendszer példa nélküli lenne, mert nem lenne elmozdulás az elnöki vagy félelnöki rendszer felé, de ,,a nép által választott elnököt dominánssá tenné.” (ÖZCAN-ELMAS-KUTLAY-MUTUS, 2009, 99) Az alkotmány 2007-es átalakítása a demokratikus intézményrendszer jelentős változásával járt. A Török Köztársaság Legfelsőbb Választási Szervezete hivatalos közlése szerint a szavazásra jogosult 42.665.149 választópolgárból 28.794.216 járult az urnákhoz, közülük pedig közel 69\% szentesítette a módosításokat. A török demokrácia történetének ötödik referendumán, a megyékre lebontott eredmények átvizsgálása során azt tapasztaljuk, hogy a legtöbb helyen az igenek győztek. Kivételt képeztek a hagyományosan baloldali szavazókörök az ország európai felén és az égeitengeri partvidéken, valamint a zömmel az alevi vallási kisebbség által lakott, kelet-anatóliai Tunceliben. Ez azt jelenti, hogy az AK Parti hagyományos bázisának tekinthető anatóliai szunnita muszlimokat sikerrel szólította meg, ám nem sikerült áttörést elérnie azokon a területeken, ahol amúgy sem bírt komoly tömegbázissal. Ugyanakkor elmondható, hogy a 69\%os támogatottság, több mint kétharmados felhatalmazást adott a kormánypártnak, amely esélyt kapott arra, hogy a későbbiekben újabb alkotmánymódosításokkal is élhessen.

Érdemes áttekinteni, hogyan hatott a 2007-es a demokratizálás kérdésére. A nemzetgyülési képviselőket a népszavazást követően már nem öt, hanem négy évre választják, ami lehetővé teszi, hogy a népi elégedetlenség hamarabb leválthasson egy rosszul müködő kormányt, s könnyebben elszámoltathatóvá válnak a képviselők. Hasonlóképpen a polgárok politikai szerepvállalását erősíti az, hogy a köztársasági elnök nép általi választásáról is döntöttek. Bár Törökország továbbra is parlamentáris rendszer marad, és a köztársasági elnök a nemzet egységét megtestesítő, szimbolikus vezető, a népi felhatalmazás mégis demokratikusabb és garantálja azt, hogy az elnök személye mögött nem csupán egy szűk hatalmi elit, hanem egy szélesebb körü választói csoport álljon. A 101. törvénycikk módosításával az elnökké választhatóság kereteit is meghatározták. Az a személy válhat - maximum kétszer öt évre köztársasági elnökké, aki legalább negyven éves, felsőfokú végzettségü, és megszerzi 20 parlamenti képviselő támogatását. Megengedett, hogy a különböző parlamenti pártok közös jelöltet állítsanak. Más választási rendszerekkel való összevetés esetén meglepőnek tünhet az az elvárás, hogy a jelölt nem lehet negyven évnél fiatalabb, azaz ezzel kizárják a választók egy jelentős rétegét a választhatóságból. Különösképpen azért lehet ez érdekes, mert Törökország még mindig egy fiatal társadalom, ahol a lakosság közel kétharmada (64,8\%-a) negyven év alatti. A Török Statisztikai Hivatal 2014-es számításai szerint az ország lakossága 77.695.904 
fö. Ebből 27.343.261-en lépték már át a negyvenéves korhatárt, azaz az elnökválasztáson a lakosság csupán 35,2\%-a indulhat. A kor alapján müködő cenzus egyrészt az oszmán hagyományokban gyökeredzik, másrészt megegyezik a török népi elvárásokkal is. Az 1876ban bevezetett Kanun-i Esasi nevet viselő választójogi törvény ugyanis 30 éves korban határozta meg a választhatóságot. (DAVIDSON, 1973) Ezt a korhatárt az AK Parti kezdeményezésére a nemzetgyülési képviselők esetén 25 évre csökkentette az 5522-es számú jogszabály. A törvényi szigor forrása a török emberek társadalomszemlélete. A törökök többsége számára egy fiatal férfi vagy nő nem számít megfelelő vezetőnek, nem veszik komolyan a politikai életben, azaz a nyugati szemlélő számára magasnak tünő korhatár a törökök többsége számára nem okoz problémát.

A választási rendszer átalakításán túl a 2007-es népszavazás a Nagy Török Nemzetgyülés müködési elvén is változtatott. A 96. Törvénycikk új szövege szerint a parlamenti ülés csak akkor érvényes, ha a teljes képviselői létszám harmada megjelenik, a szavazás pedig akkor törvényes, ha a parlament tagjainak egynegyede plusz egy fő az adott javaslat mögött áll. Ez a módosítás a képviselök személyes felelősségét hangsúlyozza. A török parlamentben tehát nem fordulhat az elö, hogy csak a képviselők töredéke hallgatja a szónokot vagy szavaz az ország jövőjét érintő kérdésekről. A részvételi kényszer a szavazói akarat megnyilvánulásának kényszere is, hiszen a voksolók nem azért küldik a képviselőket Ankarába, hogy ne az ülésteremben legyenek. Ez a változtatás aktívabb parlamenti munkát és hatékonyabb törvénykezést jelent.

A 2007-es népszavazás eredménye siker volt az AK Parti számára, hiszen saját elvei szerint alakíthatta át az ország berendezkedését és az ,alkotmányos csatában” az ő akarata érvényesült Sezer elnökével szemben.

A 2007-es alkotmányreformot követően 2010-ben egy huszonhat cikket érintő javaslatcsomagot bocsátott szavazásra Abdullah Gül köztársasági elnök. A szeptember 12-én a szavazófülkék magányában a szavazók 57,88\%-a mondott igent a Nagy Török Nemzetgyülés által már elfogadott módosításokra. Bár ez is stabil többségnek mondható, ez alkalommal a 2007-esnél 11\%-kal kevesebben támogatták az AK Parti javaslatait. Több olyan megye is volt, ahol 2007-ben az igenek, 2010-ben viszont a nemek diadalmaskodtak. A hagyományos baloldali fellegvárak mellett a billegő körzeteknek nevezhető tengerparti megyék és azok hátországai, valamint Bilecik, Eskişehir és Artvin lakosainak többsége is a nemre voksolt, akárcsak az alevi és kurd kisebbségek által is benépesített Tunceli. A csökkenés mögött nem a javaslatok milyensége áll, hanem a nyolc éve kormányzó AK Parti kezdődő 
népszerüségvesztése. Ugyanakkor a kormány még láthatóan jól teljesített, saját szavazóinak többségét jól mozgósította.

A reform egyik hangsúlyos eleme az Alkotmánybíróság szerkezetének és müködésének átalakítása. A javaslatcsomag 26 pontjából hét ezt a témakört érintette. Ezentúl a törvényességi felügyeletet ellátó szerv nem 11 tagból és 4 póttagból, hanem 17 tizenkét évre kinevezett bíróból áll. Változás az is, hogy egy alkotmánymódosítás elutasításához vagy egy politikai párt betiltásához a tagok 3/5-e helyett, kétharmaduk egyetértő szavazata szükséges. Mindössze két évvel a már az előző fejezetben ismertetett, az AK Parti betiltását célzó per után fontos döntésről van itt szó. Föleg, ha figyelembe vesszük, hogy a török pártrendszer szerves fejlödését hányszor megakasztotta az AK Parti elödjeinek vagy éppen a szélsőbaloldali pártoknak a jogi megszüntetése. A nyugati demokráciákban is előfordul, hogy szélsőséges pártokat felszámolnak, de Törökországban ezen referendum előtt szokássá vált a centrumhoz közel álló politikai ellenfelek ilyen formán való „kiiktatása”. A döntés a demokratizáció szemszögéből tehát azt jelenti, hogy ezentúl nem a bírók, hanem a szavazók dönthetnek egy-egy politikai erő sorsáról. Az Alkotmánybíróságot érintő változások között jelentős még az, hogy a török állampolgárok természetes személyként fordulhatnak a testülethez. Ez a döntés egyértelmüen a részvételi demokrácia felé tett komoly lépés.

A javaslatcsomag második tárgyterülete a Legfelsőbb Bíróság és Ügyészség reformja. Bár az igazságügyi miniszter megmaradt a testület vezetőjének, a tagok száma 7 rendes- és 5 póttagról, 22 rendes- és 12 póttagra bővült. A bírói testület jogköre is megváltozott azzal, hogy jogot nyertek arra, hogy a munkájukból fakadóan méltatlanná váló jogászokat eltilthatják szakmájuk gyakorlásától.

A harmadik jelentős téma a katonai bíráskodás kérdése. A javaslatcsomag ezen része a török társadalom „demilitarizálását” célozza, amiről a következő fejezetben részletesebben is fogunk szólni. Ezen döntések között kiemelendő, hogy a katonák köztörvényes bűncselekményeiről 2010 után a polgári bíróságok dönthetnek, míg békeidőben civileket nem lehet hadbíróság elé állítani. Törölték a hírhedt 15. törvénycikket is az alkotmányból, amely eddig megakadályozta, hogy felelősségre vonják az 1980-as katonai puccs szereplőit.

Az alkotmánymódosítás eredményeképpen bevezetésre került az ombudsman intézménye. Az Alapvető Jogok Biztosának Hivatala a TBMM elnöke alá tartozik. Vezetőjét titkos szavazással a parlament kétharmada választja meg. A svéd mintára létesült jogintézmény az állampolgárok jogbiztonságának garantálását hivatott megvalósítani. Az intézmény puszta léte már egyértelmű jele a demokratizálódásnak, ám ha a 2013-tól megszületett döntéseit nézzük végig, akkor azt látjuk, hogy a polgárok számos, elsősorban munkajogi problémájára nyújt 
gyógyírt az ombudsman. Szintén a munkajog kérdéskörét érinti az alkotmányreform azon döntése, mely szerint a közalkalmazottak jogot nyertek arra, hogy kollektív szerződésben rögzítsék jogaikat és kötelességeiket.

A török társadalmat demokratikusabbá tévő két alkotmányreformnak pozitív visszhangja volt külföldön is. A két alkotmányreform az EU-hoz való közeledés mellett kettős hatással bírt: egyrészt kiterjesztette a demokratikus szabadságjogokat, másrészt stabilizálta a Török Köztársaság müködését. A demokratizálást szentesítő két népszavazás pedig egyesítette és aktivizálta az AK Parti szavazói bázisát, témává tette a közéletet, és ezek segítségével garantálta, hogy a párt hosszú távon is hatalmi tényező maradhasson. Ugyanakkor egyértelmü, hogy az AK Parti részéről ez a demokratizálás egyben harc is volt, a hatalmát korlátozó fékek és ellensúlyok elleni küzdelem, mely során kiemelt szerepet kapott a pártot betiltani szándékozó alkotmánybíróság átalakítása, illetve a hadsereg háttérbe szorítása.

\subsection{A török társadalom „demilitarizálása”}

A török társadalomban a köztársaság kikiáltása óta kiemelt szerepe volt a honvédségnek. Az államalapító is hadvezér volt, illetve máig létezik a kötelező sorkatonaság intézménye, valamint a török katonaság jelenleg is az egyik legnagyobb létszámú a világon. Témám szempontjából ugyanakkor a hadsereg azért válik jelentőssé, mert a török közelmúltban háromszor is komolyan beleavatkozott a demokratikus fejlődés alakulásába, 1960-ban, 1971-ben és 1980ban is az államcsíny eszközéhez nyúlt. (A negyedik, 2016-ban történt sikertelen puccs kísérletről a 3. fejezetben részletesen kitérek.) A hadsereg ezen fegyveres beavatkozásokon túl az AK Parti kormányzása idején is, 2007-ben, kiadott egy olyan sajtóközleményt, ami félelmet keltett mind a politikusok, mind pedig a lakosság körében, mert felvetette annak lehetőségét, hogy a katonák negyedszerre is „,kijöjjenek a laktanyákból”, azaz megdöntik a demokratikusan választott kormányt. A három puccsot és az 2007-es fenyegetést annak köszönheti a török társadalom, hogy mélységesen megosztott, és a hadsereg az egyik politikai oldal mellé állt. Egy stabil és demokratikus Törökországban a katonaság nem lehet a demokratikus politikai közélet egyik vagy másik oldalán, a hadsereg fő szerepe az ország területi integritásának biztosítása, és nem az, hogy a bármely politikai oldal egyik „háttérintézménye” legyen, így érthető az AK Parti azon törekvése, hogy a honvédséget kiszorítsa a politikai porondról, és visszaterelje öket a laktanyákba. 


\subsubsection{A hadsereg társadalmi jelentősége}

A Török Fegyveres Erők (Türk Silahlı Kuvvetleri, TSK) létéről és működéséről a mindenkori hatályos alkotmány rendelkezik. Főparancsnoka a köztársasági elnök. Három alapvető egységre tagolható: szárazföldi erők, tengeri- és légierő. A Csendőrség és a Parti Örség békeidőben ugyan a Belügyminisztérium hatáskörébe tartozik, ám szervezetileg ők is a hadsereg részét képezik. Teljes létszámát tekintve a török haderő a világ nyolcadik, a NATO második legnagyobb hadserege.

Törökország hosszú történelmi fejlödés következtében jutott oda, hogy ma ilyen jelentős katonai erővel bír, és az ilyen komoly befolyással van a társadalomra. Az Oszmán Birodalom utolsó éveiben, 1911-ben hívták életre az ún. Repülős Bizottságot, ami a mai légi haderő őse. A köztársasági korszak egyik legfontosabb eseménye az, hogy 1952. február 18-án Törökország csatlakozik a NATO-hoz.

A török hadsereg sajátossága a kötelező sorkatonai szolgálat. Az Oszmán Birodalom idején, még 1916-ban, azaz az első világháború folyamán döntöttek arról, hogy minden 19 évnél idősebb férfinek be kell vonulnia. A köztársaság kikiáltása után a hadseregnél töltendő idő a fegyvernemektől függően 18 és 60 hónap között változott. A 2014-ben módosított szabályozás szerint a sorkatonai szolgálat időtartama 12 hónap. Ez azt jelenti, hogy az AK Parti két lépésben, 2003-ban és 2014-ben összesen hat hónappal csökkentette a laktanyában töltendő időt. Lehetővé vált az is, hogy a vendégmunkásként külföldön dolgozó török állampolgárok pénzen megváltsák a szolgálati időt. (ISIKLAR, 2011)

Egyértelmü, hogy egy ilyen impozáns történelmi múlttal rendelkező és ilyen jelentős állománnyal bíró haderő, ahol a férfiak életük egy évét is eltöltik, komoly társadalomformáló potenciállal bír. A katonai szférából érkező államalapító, Musztafa Kemál Atatürk felmérve azt az erőt, amit a hadsereg képvisel, a katonaságot a politikai rendszer támaszává tette, ez vezethetett el oda, hogy a 20. század során négy alkalommal is beavatkozott a TSK a demokrácia alakulásába.

A katonai puccsok történetének részletes bemutatása előtt érdemes Dekmejian és Narli továbbfejlesztett korszakolását alapul venni, hiszen ahogy a szakirodalmi áttekintésben említettük, részletesen foglalkozott a török hadsereg történetével és kiváló elméleti keretet kínál erre.

A korszakolás szerint a civil és katonai kapcsolatok közötti viszony folyamatosan változott, hol erősebben érvényesült a civil uralom és a polgárok akarata, hol pedig katonai puccsokkal 
kellett a török társadalomnak megbirkóznia. Látható, hogy Narli 2005-ös müvében már úgy látja, hogy az AK Parti kormányzása alatti időszak egy erőteljes elmozdulás a civil uralom felé. (NARLI, 2005, 229-258) A katonai uralom és a katonai kontroll bevezetését jelentő puccsok tárgyalása után látni fogjuk, hogy az AK Parti további kormányzása alatt jelentősen csökkent a hadsereg befolyása az államügyekre.

\subsubsection{A katonai puccsok története}

Minden török politikai szereplő számára meghatározó élmény a 20. század második felében bekövetkezett három katonai hatalomátvétel. A puccsok egyrészt növelték a bizonytalanságérzést ahelyett, hogy elősegítették volna az ország biztonságának erősítését, másrészt komoly, máig ható pszichózist okoztak; a török nép még a 2000-es években is tartott attól, hogy a fegyveres erők magukhoz ragadják a hatalmat, mondván az AK Parti politizálása ellentmond a szekuláris államrend elvének.

Az első katonai államcsíny Törökországban 1960. május 27-én következett be. A puccsot több alacsony rangú katonatiszt szervezte meg, de később számos magas rangú vezető is csatlakozott hozzájuk. A katonai hatalomátvétel mögött a Menderes-kormány és a hadsereg folyamatos súrlódásai és a tiszti állomány elégedetlensége állt. Adnan Menderes tízéves kormányzása során mindvégig kritikus maradt a fegyveres erőkkel. 1957-ben egy alkalommal a következőket mondta: ,egyszer én még betöröm a lovagi orrotokat: ezt a hadsereget tartalékos tisztekkel is elvezetem” (ERİNÇ, 1998) A meglepő kijelentés mögött az állt, hogy a vezérkari tisztek többsége igyekezett Menderes és a Demokrata Párt elképzeléseinek kerékkötőjeként fellépni. Sokan közülük kevésbé voltak müveltek, és nem szimpatizáltak a többpártrendszerrel, az 1950-es évek tartalékos tisztjei viszont sokan egyetemet vagy gimnáziumot végeztek, nyitottak voltak az új politikai rendszer felé, sok esetben a DP támogatóinak számítottak.

A választási rendszert átalakító, a katonák mozgásterét korlátozó Demokrata Párt és kormánya ellen 1957-től kezdve egyre több, eleinte elszigetelt katonai szervezkedés indult meg. Ezen puccskísérletek közül az első az ún. ,kilenc tiszt ügye” volt. A Faruk Güventürk alezredes köré szerveződött csoportnak számos tiszten kívül újságírók és egy parlamenti képviselö, Mithat Perin is tagja volt. Hat hónapos bírósági eljárást követően 1958-ban a szervezkedés egyes vezetöit kétéves börtönbüntetésre ítélték, ám többen közülük visszatérhettek a katonaság kötelékébe. (YALCIN-YARDAKUL, 1999, 93) Egy hasonló csoportosulás Ankarában is működött. A két titkos társaság már 1957-ben egymásra talált. A tervük az volt, hogy az 1957- 
es választási kampány idején, egy rendezvény során a tribünön helyet foglaló kormánytagokat letartóztatják, és átveszik a hatalmat. (ASLADAS-BICAKCI, 1995, 66-67)

Azt követően, hogy a miniszterelnököt szállító repülőgép balesetet szenvedett London közelében, a politikai oldalak között némi béke látszott megvalósulni. A sajtó- és turisztikai miniszter, az Anatólia Hírügynökség és a Turkish Airlines igazgatóinak halálával járó szerencsétlenséget Adnan Menderes élve és komolyabb sérülések nélkül megúszta, ezzel a „csodás megmeneküléssel” sikerült politikai hatalmát még egy időre megőrizni, s a katonai vezetők is elhalasztották a mozgolódást. Nem telt bele két hónap, 1959 áprilisában kiújultak a kormányzó demokraták és az ellenzéki néppártiak közötti villongások, egyre több lett az erőszakos incidens. Többek között politikusokat, így a volt államfőt, İsmet İnönüt is nemtelen támadás érte. Az egyre sokasodó tüntetések és polgári engedetlenségi mozgalmak, valamint a diákság tüntetései végett több katonai egység parancsnoka úgy döntött, hogy elindulnak tankjaikkal, és átveszik a hatalmat. Az 1960. május 27-én hajnali fél négykor laktanyáikat elhagyó katonák alig egy óra alatt sikerrel jártak. Cemal Gürsel későbbi köztársasági elnök vezetésével létrejött a Nemzeti Egységbizottság, ami átvette az ország kormányzását. A katonai puccsot követően Adnan Menderest és két miniszterét kivégezték, számos más politikus hosszú börtönbüntetést kapott.

A puccs végrehajtói egyértelmüen a politikai jobboldalt büntették, és a politikai baloldalnak igyekeztek kedvezni, „kiterjesztették a munkások jogait, szélesítették a gyülekezési és az egyesülési jogot”. (MAVI, 2010, 38) Nem mellékes ebben a tekintetben az, hogy a lázadó tisztek között sok volt a baloldali szimpatizáns, ezért volt az, hogy „ebben az időben fontosnak tartották a demokratizálás folytatását és a civil szervezetek támogatását”. (AKINCI, 2014, 62)

A katonai hatalomátvétel sokkolta a török közvéleményt. Jellemző arra a pszichózisra, amit a puccs okozott az, hogy számos hamis hír kelt lábra arról, hogy a katonák diákokat vagy éppen a DP támogatóit ölték meg, és földelték el titokban. Öket a nép a „szabadság mártírjainak” nevezte el. Bár 1957 és 1960 között egyértelmüen zürzavaros napokat élt meg Törökország, a puccs olyan hatással volt az országra, amit csak több év elteltével tudott feldolgozni. A konzervatív politikai oldal hívei máig nem tudják maguknak megbocsátani, hogy hagyták a körükben népszerü miniszterelnököt kivégeztetni. Ugyan a puccsot kiváltó okok között ott leljük a politikai iszlámtól való félelmet, a vallást a puccsisták is felhasználták politikai célokra, hiszen a „katonai kormányzat 1960 és 1961 között az iszlámot használta ideológiai alapként reformjai megerősítése céljából”. (SAKALLIOGLU, 1996, 268) Annak ellenére, hogy a tisztek a vallásra hivatkoztak, az 1960-as puccs és Menderes felakasztása a mai AK Partihoz közel álló körökben máig ható, mélyen gyökerező gyanakvást szült a hadsereggel szemben. 
Az 1960-as fegyveres beavatkozással ellentétben 1971-ben egy vértelen puccs kényszerítette lemondásra az akkori kormányt. A különböző fegyvernemek parancsnokai 1971. március 12-én levélben küldött parancsban fordultak Cevdet Sunay államföhöz, hogy mondassa le a kormányt. Az államcsíny hátterében az állt, hogy az 1960-as években megerősödtek a szovjetbarát, baloldali erők, akik egyre inkább egy szocialista forradalom szükségességét hirdették. Ez pedig újabb utcai csatározásokhoz vezetett, 1969-ben az isztambuli Bejazid téren kövekkel és botokkal estek egymásnak a baloldaliak és az antikommunisták. A „véres vasárnapnak" is nevezett esemény után már 1969 májusában volt egy elvetélt puccskísérlet, amit egy később visszavont alkotmánymódosítási javaslat motivált. 1970-ben egy újabb, a Munka Törvénykönyvét és a szakszervezeti törvényt érintő módosítás radikalizálta a szélsőbaloldalt, és a szakszervezetek hatalmas tömeget vittek ki Isztambul utcáira. A város ázsiai oldalán bekövetkező villongásokban két munkás, egy kereskedő és egy rendőr vesztette életét. A katonaság a szélsőbaloldali veszély komolyságát érzékelve lépett müködésbe, 1971. március 9-ére tervezték az újabb fegyveres hatalomátvételt, ám ez kitudódott és meghiúsult. Három napra rá született meg a fent említett levél. Még abban az évben volt egy újabb sikertelen katonai államcsíny-kísérlet, utána kilenc évre visszavonulót fújt a hadsereg. A hatalmat megdöntő katonaság arra kényszerítette a parlamentet és a kormányt, hogy néhány tekintetben módosítsa az alkotmányt. Így megszüntették a TRT közszolgálati csatornák függetlenségét, megtiltották a közalkalmazottaknak, hogy belépjenek a szakszervezetbe, az előzetes letartóztatás időtartamát pedig 24 óráról 15 napra emelték. (MAVI, 2010, 49)

Az 1960-as és az 1971-es események között bizonyos mértékig tudunk párhuzamot vonni, ám jelentős különbségek is vannak. Mindkét esetben a kiváltó okok között ott van a kormány erőből való politizálása, a társadalmi elégedetlenség ellenére zajló törvénykezés. Mindkét esetben meghatározó a külpolitikai helyzet is, míg 1960-ban Menderesről gondolta a katonaság, hogy a Szovjetunióhoz közeledne, addig 1971-ben a szélsőbaloldaliak egyértelműen ilyen jellegü követelésekkel álltak elő. Végül mindkét esetben a kiváltó okok között találjuk a véres tüntetéseket, amelyeket elfajulásáért a rendőrség tehetetlensége is okolható. A legfőbb különbség a katonai beavatkozás mögötti ideológiai háttérben keresendő: 1960-ban az iszlamizmus, 1971-ben a kommunizmus fenyegetését tartották olyan mértékünek, hogy lépésre szánták el magukat a tisztek.

Az 1980. szeptember 12-ei katonai puccs gyakorlatilag hatályon kívül helyezte az addigi politikai rendszert, noha a hadsereg deklaráltan a demokrácia visszaállításának jelszavával indította akcióját. (NARLI, 2005, 239) Lemondatták Süleyman Demirel kormányát, 
feloszlatták a Nagy Török Nemzetgyülést és eltörölték az első puccs után megalkotott, 1961-es alkotmányt, ezzel együtt betiltották az összes politikai párt müködését.

Az államcsíny ürügye - az előző esetekhez hasonlóan - 1980-ban is egy, a puccs előtt hat nappal rendezett politikai nagygyülés volt, amit az AK Parti egyik ideológiai őse, Necmettin Erbakan szervezett a konzervativizmusáról ismert belső-anatóliai nagyvárosban, Konyában. Az ún. Jeruzsálem Meeting során a résztvevők az iszlám vallás harmadik legszentebb városa, Jeruzsálem békéje és biztonsága mellett tüntettek. A demonstráció során államellenes jelszavak is elhangoztak, egyesek az iszlám jogrend bevezetését követelték. Erre azért is sor kerülhetett, mert éppen politikai vákuum uralkodott az országban, a TBMM 114 forduló után sem volt képes köztársasági elnököt választani. A belpolitikai okokon túl külpolitikai okai is voltak az eseményeknek. Egy évvel az Iráni Iszlám Köztársaság kikiáltása és Afganisztán szovjet megszállása után Törökország geostratégiai helyzete felértékelödött, különösképpen a NATOban betöltött szerepe lett egyre fontosabb. Egy ilyen bonyolult katonapolitikai helyzetben az erős török hadsereg akarta az államot irányítani, és nem fordítva.

Az 1980-as puccsnak számos előjele volt. Ezek között meg szokták említeni azt, hogy 1978 és 1980 között megszaporodtak a politikai gyilkosságok. Többek között fegyveresek végeztek Gün Sazakkal a Nacionalista Mozgalmi Párt (MHP) alelnökével. A politikai gyilkosságok mellett számos egyéb erőszakcselekmény is történt. Mindennapossá váltak a kisebb-nagyobb terrortámadások, amelyeket szélsőbaloldaliak és kurd szeparatisták követtek el. Általánosságban elmondható volt, hogy 1980-ra belső biztonsági válság alakult ki Törökországban.

A hatalomra jutó katonaság a biztonsági krízist kivégzésekkel szerette volna megoldani. 1980. október 9-én, azaz a hatalomátvétel után kevesebb, mint egy hónappal már munkához is láttak a hóhérok, amikor is felakasztották a baloldali nézeteiről ismert, 22 éves Necdet Adalıt és egy terrortámadás során öt ember meggyilkolásával vádolt, nacionalista Mustafa Pehlivanoğlut. A két kivégzés érintettjeinek politikai meggyőződése mutatja, hogy a hadsereg minden politikai oldalt egyaránt büntetni szándékozott, így kivívta gyakorlatilag minden politikai szereplő ellenérzését. A puccs után felálló Nemzeti Biztonsági Tanács hatalmas tisztogató tevékenységbe kezdett. A kivégzések mellett összesen 1.683.000 ember ellen indult politikai természetü jogi eljárás, az ezeket követő 210 ezer perben mintegy 230 ezer embert ítéltek el. Ötszáztizenhét fő kapott halálbüntetést, közülük végül ötvenet akasztottak fel.

Az utókor szerint a ,szeptember 12-ei puccs az ország legsötétebb és legantidemokratikusabb időszakainak egyike volt”. (MAVI, 2010, 66) A puccsot követően új alkotmány született és az ország számos megyéjében évekig fennmaradó katonai közigazgatást 
vezettek be. A délkeleti országrészben ezt az AK Parti kormányzásának legelső éveiben szüntették meg csupán. A katonai közigazgatás minden állampolgárra hatással volt, így mindenki megérezhette, hogy milyen is, amikor a katonaság túlzott hatalmat kap. A sok tiltás és korlátozás beleivódott a törökök lelkébe, ezért 1980-at követően mindent igyekeztek megtenni azért, hogy ne következhessen be ilyen még egyszer. A puccsok megelőzése a demokratikus jogok kiszélesítésével és a demokrácia kultúrájának megteremtésével lehetséges, mert „a puccsok elsődleges oka a demokratikus hagyományok hiánya”. (AKINCI, 2014, 68) Ugyanakkor azt se hallgassuk el, hogy a „,török demokratikus fejlődést visszájára fordító, és az ország bővülését gátoló katonai puccsok mögött ott találjuk a nemzetközi politika szereplöit is.” (BOZTAS, 2012, 71) Ez pedig azt jelenti, hogy egyedül a demokratikus hagyományok hiánya nem magyarázza a hidegháború során a NATO-tag Törökországban bekövetkező három államcsínyt, hanem azok az USA és a Szovjetunió törökországi befolyásszerzési küzdelmeként is értelmezhetöek.

Az elméleti részben felállított modellek szerint a török hadsereg az elmúlt korszakokban inkább a praetoriánus modellt - tehát az állam ügyeibe való aktív beleszólást, katonai kontrollt - követte. Azonban részben egyet kell értenünk Michael C. Desch azon megállapításával, hogy a belső konfliktusok esetén nagyobb a hadsereg beavatkozásának lehetősége. (DESCH, 2001) A szinte polgárháborús helyzet miatt az 1980-as puccs érthetőbbé válik, azonban a puccsok mögött nem állt mindig teljes belpolitikai zavar, hanem inkább arról volt szó, hogy a társadalom számottevő részétől- iszlamisták, nacionalisták, kisebbségek, baloldaliak- a hadsereg ideológiailag megkülönböztette magát, s minden csoportra idegenként és lehetséges veszélyforrásként tekintett.

Ez különösen igaz volt a hidegháború évtizedeiben, amikor a kommunista veszély az 1971es és az 1980-as puccs idején is felmerült. A belpolitikai szereplők - szakszervezetek, baloldali pártok és szélsőbaloldali csoportok - már csak azért is nagy veszélyt jelentettek az ország biztonságán őrködő honvédség szemében, mert úgy vélték, hogy az országgal határos Szovjetunió szövetségesei. A Szovjetunió közelsége miatt a NATO-tag Törökország folyamatosan veszélyhelyzetben érezte magát, s a Moszkvához való közeledést és a kommunizmus jelszavát hirdető csoportokat valós veszélyforrásként kezelte. Azonban az $1997-$ es ún. posztmodern puccs, vagy a 2007-es ún. e-memorandum esetében nem beszélhetünk belső zürzavarról, polgárháborús helyzetről, vagy a civilek részéről fennálló államcsíny lehetőségéről sem.

Az 1997-es puccs hasonlóan az 1971-es beavatkozáshoz, vértelenül zajlott. A posztmodern puccsnak nevezett katonai beavatkozás a törvényesen megválasztott Necmettin Erbakan által 
vezetett kormány ellen irányult. Az 1990-es éveket a török politikában az „elvesztegetett évtizednek" szokás nevezni, amely nemcsak a katonai puccs miatt találó címke, hanem azért is, mert ezen az időszakot az állandó belpolitikai válság és rövid életü, változó összetételü kormánykoalíciók egymás utánisága határozta meg. Az állandósult bizonytalanság megviselte a török népet, amely emiatt is másképp tekint a 2000-es évekre, amely a korábbihoz képest sokkal stabilabb kormányzást hozott. A puccs okai között is részben ezt a bizonytalanságot és a török honvédség iszlámellenességét kell keresnünk. Noha az 1995-ös választáson Necmettin Erbakan pártja, a Jólét Pártja szerezte meg a legtöbb szavazatot, csak nehezen, 1996-ban tudott kormánykoalíciót alakítani Tansu Çiller Igaz Út Pártjával.

A hadsereg azonban úgy vélte, hogy Erbakan pártja az ország szekularizmusa ellen lép fel, ami alkotmányellenes. A puccsot megelőző hónapokban több olyan esemény történt, amely a hadsereg rosszallását váltotta ki, s a beavatkozás előtt egyengette az utat. Így például Erbakan 1996. októberi fontos muszlim országokba tett látogatása (Egyiptom, Líbia, Nigéria) nagyon kemény kritikákat kapott a sajtóban, vagy az év novemberében Kayseri polgármestere, a Jólét Pártjának tagja, Șükrü Karatepe beszéde, amelyben kijelentette, hogy az országban nincs valódi demokrácia. 1997 elején Erbakan a vallási rendek vezetőit a ramadáni böjt idején szokásos esti, böjtmegtörő vacsorára, ún. iftárra látta vendégül, amelyet sok tiszt a szekularizmus megsértésével azonosított. Azonban ezeknél az eseményeknél is nagyobb horderejü volt az Ankara egyik külvárosában, Sincanban rendezett Jeruzsálem est, amelyre a szintén Jólét Pártjába tartozó polgármester, Bekir Yıldız meghívta az iráni nagykövetet. Pár nappal később, február 4-én a hadsereg tankokkal vonult be a városba. Végül február végén a Fatih mecsetnél egy csoport a saría bevezetésének szükségességét kezdte el követelni, amiböl szintén nagy visszhangot kiváltó botrány lett.

Ilyen előzmények után a Nemzetbiztonsági Tanács összeült február 28-án, s egy rendkívül hosszú, kilenc órás megbeszélés után olyan utasításokat fogalmazott meg, amelyek teljesítése összeegyezhetetlen volt a Jólét Pártjának programjával. A 28 pontból álló lista szerint korlátozni kellett volna a Korán órákat, a vallási iskolákat stb.(NARLI, 2005, 242) Ugyan Erbakan ezt végül aláírta, de a török társadalom megrendült a felülröl kikényszerített intézkedések láttán. A Jólét Pártja nem is maradt sokáig a kormánykoalícióban: 1997 nyarán Necmettin Erbakan lemondott, s az új miniszterelnök Süleyman Demirel kinevezése alapján Mesut Y1lmaz lett. Később pedig az alkotmánybíróság feloszlatta a Jólét Pártját, melynek vezetői hamarosan megalapították újabb pártjukat. A hadsereg a nyomásgyakorlás egyéb eszközeit használta tehát, és az 1997-es ,posztmodern puccs” idején a hadsereg a fegyveres beavatkozás helyett komoly médiakampányt folytatott az iszlamisták megbuktatására, amely 
összességében legitimálni tudta a kormány lemondását, avagy lemondatását.” (EGERESI, 2013, 2)

Érdemes megjegyezni, hogy a vizsgált időszakunkat követően, 2016. július 15-én is bekövetkezett egy elvetélt államcsíny, mely radikálisan megváltoztatta a Török Köztársaság politikai életét, illetve ami után két évre rendkívüli állapotot vezettek be az országban. A török hivatalos álláspont szerint ez a puccs sok tekintetben hasonlított az azt megelezőkhöz, azaz szekuláris szimbólumokat használt annak érdekében, hogy megnyerje magának a kemalista rétegeket, ám a végrehajtók a kormány feltételezése szerint valójában egy vallási szervezet, a Gülen mozgalom tagjai voltak. (YAYLA, 2017, 28-29) Bár már az Erdoğan-kormányt 2013 decemberében ért korrupciós vádak idején is előfordult, hogy használták, a 2016. július 15-i puccskísérlet után a török hivatalosság erre a csoportosulásra FETÖ-ként, azaz Fetullahista Terrorszervezetként szokott hivatkozni, és őket teszik felelőssé a mintegy 250 civil és katonai áldozatért. (YAYLA, 2017, 32) Ezeket az áldozatokat a török kormányhoz közel álló elemzők a demokrácia dicsőséges védelmezőinek tartják, ugyanakkor Recep Tayyip Erdoğan kritikusai nem felejtik el megjegyezni, hogy számos összeesküvés-elmélet létezik, melyek szerint az eseménysor egy ún. hamis zászlós hadmüvelet, melynek éppen az a célja, hogy a török vezetőt áldozatnak állítsák be és az így az tovább erősíthesse autoriter hatalmát. (FABBE, 2016, 9)

2.5.3. A hadsereg háttérbe szorítása az euroatlanti integráció és a demokratikus átmenet erősítése érdekében

A török hadsereg haderejét és a puccsok hosszú sorát figyelembe véve 1980 után egyre inkább megfogalmazódik a civil lakosság körében az az igény, hogy a katonaság vonuljon ki a politikából, illetve váljon büntethetővé a puccsokban való részvétel, valamint ne fordulhasson elö olyan, mint 1997-ben, amikor is a hadsereg arra kényszerítette a kormánykoalíció egyik pártját, hogy lépjen ki a kabinetből. Ahogy említettük, a civil kontroll elérése egyre fontosabbá vált a török politikai elit részéröl, annak ellenére, hogy a korábbi időszakokban erre kevés lehetőség volt. Ebben az irányban nagy előrelépést jelentett - mint arra már utaltunk az előző fejezetben -, amikor az AK Parti által kezdeményezett alkotmánymódosítási csomagról 2010ben népszavazáson dönthettek a választók. A hadsereg háttérbe szorítása ugyanakkor együtt kellett, hogy járjon az ország külső és belső biztonságának szavatolásával, hiszen belföldön továbbra sem csökkent a terrortámadások száma, és bár történt közeledés, a kurd terrorista PKK fegyveresei még mindig veszélyt jelentettek, illetve számolni kellett a határok mentén, Szíriában és Irakban zajló polgárháborúk hatásaival is. (Mindemellett az AK Parti a hadsereggel 
és a hadiiparral kapcsolatban stratégiai célokat is megfogalmazott. Ennek eredménye az, hogy Törökország ma már képes az összes jelentős konvencionális fegyver hazai tervezésére és gyártására.)

Az AK Parti kormányát megelőzően a hatalomban lévő Ecevit-kabinet eleinte gyakorlatilag még a katonaság kezében volt, a civil-katonai kapcsolatokban inkább a hadsereg dominanciája érvényesült. Nem a kormány felügyelte a hadsereget, hanem fordítva. Az akkori kormányhoz közelálló Miliyet például így idézi a miniszterelnökhöz látogató vezérkari főnököt, Hüyesin Kıvrıkoğlut azzal, kapcsolatban, hogy megkapták-e a kormánytól a kért támogatást: „amit kérünk, mindig megadják”. (KIVRIKOGLU, 1999) 2001-ben azonban az Ecevitkormány is érzékelni kezdte a hadsereg túlsúlyát. Ne felejtsük el, hogy ez volt a mély politikaigazdasági válság időszaka, amit egy megszorító intézkedésekből álló, neoliberális korszak követett. Ebben a válságos helyzetben született meg a 2945-ös számú törvény, amely átalakította a puccsisták által életre hívott Nemzeti Biztonsági Tanácsot. A Tanács - amelybe nem kevés civil tagot is kooptáltak, és ami eddig gyakorlatilag a kormány fölött állt, a végrehajtó hatalom konzultációs testületévé lényegült át. Ezt a lépést tekinthetjük a hadsereg háttérbe szorítása prelüdjének.

A civil és a katonai kapcsolatok átalakulásában nagy szerepet játszott egy külső, a honvédség és a civil kormányok által legitimnek tartott tényező, az Európai Unió követelései, amelyek a praetoriánus rendszerből az Európában megszokott professzionális modell felé kívánta elmozdítani a hadsereget. Az AK Parti 2002-es parlamenti győzelme egy erősen integrációpárti programmal nagy lökést adott a honvédség szerepének átértékelésében. A koppenhágai kritériumok által megkövetelt demokratizálódás az uniós csatlakozás egyik előfeltétele, amit az AK Parti kormányok nem hagyhattak figyelmen kívül, és ez találkozott a török nép igényével is. A következő években, akárhányszor merült fel feszültség vagy konfliktus a vezérkar és a kormány között, az Európai Unió a civil kormányzatot támogatta, s ez megkönnyítette a hadsereg túlzott hatalmát leépítő reformok lépcsőzetes bevezetését. A hatalomból kiszoruló kemalista elit az Európai Unió szoros felügyeletét komoly tragédiaként élte meg. Egyenesen az EU hadsereg-ellenességéről cikkeztek a 2000-es évek közepén. (KOC, 2006)

Az EU tehát már nem csupán mint elvárásrendszer jelent meg, hanem kvázi belpolitikai legitimáló erővé is vált, a pártpolitikai csatározások során erős tényezőnek bizonyult.

A megkezdett reformokat folytatva, a Nemzeti Biztonsági Tanács mozgásterét az AK Parti kormánya tovább szükítette. A szervezet 2003 után civil főtitkárt kapott, és előírták nekik, hogy üléseiket nem tarthatják sűrübben, mint két hónap, azaz évente csupán hat tanácskozásra 
kerülhet sor. Egy másik 2003-as törvénymódosítás pedig arra adott felhatalmazást a Nagy Török Nemzetgyülésnek, hogy beleszólhasson a hadsereg költségvetésébe, ami alapvető kérdés volt a demokratizálás szemszögéből is, hiszen a klasszikus parlamentáris demokráciákban nem a fegyveres erők alkotják meg saját büdzséjüket, hanem a törvényhozás. A parlamenti kontroll növelése 2008-ban oda vezetett, hogy már nem a katonai kiadások voltak a legjelentősebbek, attól az évtől kezdve többet áldoztak az oktatásügyre, mint a honvédelemre. Komoly változtatásokon ment keresztül az ún. Katonai Büntető Törvénykönyv is. A még Atatürk idején, 1930-ban meghozott jogszabályt már az Ecevit-kormány is több helyen megváltoztatta, ám a 2007-es alkotmányreformnak köszönhető volt, hogy civilek felett békeidőben nem ítélkezhetnek a katonai bíróságok. A hadsereg térvesztését jelenti az is, hogy a katonák kikerültek két fontos köztestületből, a Felsőoktatási Tanácsból (YÖK) és a Rádió- és Televízió Testületből (RTÜK), azaz nem tudták tovább befolyásolni az oktatási segédanyagokat és a médiatartalmakat.

Az egyre sürűsödő korlátozások, és az ezzel párhuzamosan megerősödő civil kontroll részleges visszavonulásra kényszerítette a katonaságot. Az egyik legegyértelműbb jele ennek az, hogy egyre kevesebbet szerepelnek a katonák a médiában, egyre kevesebb sajtóközleményt adnak ki, azaz egyre inkább a klasszikus biztonságpolitikával foglalkoznak. Ezt azzal magyarázhatjuk, hogy a török hadsereg is felismeri, hogy az ország előtt egy nagy és magasztos cél áll, az európai integráció. Ennek sikere érdekében képesek időlegesen félretenni ellenérzéseiket a kormányzó párttal szemben, és a biztonságpolitikai kérdésekre koncentrálnak a hatalmon lévők kritizálása helyett.

Ahogy a török politikai erők az Európai Unió teljes egyetértésével igyekeztek egyre több jogot megvonni a hadseregtől, és maga a TSK is belátta, hogy „fel kell adnia egyes hadállásait” a politikában és a közéletben, lehetőség nyílt arra, hogy végleg felszámolhassák a törökök a belső politikai konfliktusok fegyveres megoldásának jogi hátterét, amit az első puccsisták által 1961-ben megfogalmazott 211. törvény rögzített. A Fegyveres erők belső szolgálati szabályzatáról szóló törvény inkriminált 35. cikkelyét az AK Parti végül az ellenzéki Köztársasági Néppárt (CHP) támogatásával módosította. A 2013-as új törvényszöveg egyértelművé teszi, hogy mi a honvédség kötelessége: ,„a fegyveres erők feladata a határokon túli veszélyforrásokkal szemben a haza védelme".

A civilek és katonák viszonyának normalizálódását vizsgáló Tanel Demirel szerint „egyrészt a hadsereget kitüntetett tisztelet illeti meg, másrészt a hadseregnek a demokratikusan választott kormányt kell követnie”. (DEMIREL, 2010, 23) A lassan változó török katonaság ma már a kormányzati politika egyik kiszolgálója lett, és a klasszikus biztonsági kérdésekkel 
foglalkozik, a kormány pedig mindent megtesz, hogy a török fegyveres erőket a legkorszerübb, hazai gyártású eszközökkel lássa el. A Nemzeti Tankgyártási Projekt (Milli Tank Üretim Projesi, MiTÜP) keretei között 2007-re elkészült az első török tank, az Altay AMT. 2008-ban egy évtizedes álom valósult meg azzal, hogy kifutott a vízre a MILGEM, az első török készítésü hadihajó, egy korvett. Olasz együttműködéssel 2009-től gyártják a T-129 ATAK elnevezésü harci helikoptereket. 2010-ben ANKA néven pilóta nélküli robotrepülők sorozatgyártásába fogtak Törökországban. Az itt felsoroltak csak kiragadott példák arról a hosszú listáról, amely a török katonai fejlesztéseket tartalmazza. Ezek az új fegyverek is azt példázzák, hogy a török ipar fejlődőképes, a hadsereg továbbra is ütőképes, de már nem az a célja, hogy ezt a potenciált belföldön használja fel egyik vagy másik politikai oldal érdekében.

A 2016-os elvetélt államcsíny megmutatta a török társadalom számára azt, hogy egyrészt a fegyveres erők még mindig számottevő befolyással bírnak a politikai rendszer és a politikai folyamatok tekintetében, másrészt pedig arra is rámutatott, hogy még akkor is előfordulhet puccsveszély, ha a puccsistákhoz csupán kevesen, a hadsereg katonáinak mindössze néhány százaléka csatlakozik abban az esetben, ha mögöttük egy jól szervezet, titkos hálózat körvonalai látszódnak meg.

Az AK Partit a puccskísérlet azonnali lépésekre kényszerítette. Az elnöki rendszerre való áttérés ezt a folyamatot is komolyan befolyásolta azzal, hogy a hadsereg fóparancsnokát ezután személyesen az elnök nevezi ki. Sőt, az elnök megkapta azt a jogot is, hogy személyesen adjon ki katonai parancsot a hierarchia bármelyik szintje számára, ehhez pedig nincs szüksége arra, hogy az utasítás végighaladjon az eddig megszokott láncolaton. Ezzel párhuzamosan a Legfelsőbb Katonai Tanács (YAS) elvesztette számos eddigi jogkörét, amit ezután szintén a köztársaság elnöke fog gyakorolni. (HAUGOM, 2019,6) Az elnöki rendszerre való átteres sok tekintetben jelentős hatalomkencentrációt eredményezett a török politikai szisztémában. Nincs ez másképpen a fegyveres erők irányítása esetén sem. Ugyanakkor érdemes megjegyezni, hogy itt az elnöki jogkörök kiszélesítése egyben a hadsereg feletti civil kontroll megerősödését is jelenti, azaz jelentősen hozzájárulhat a tényleges demilitarizáláshoz és a további államcsínyek megakadályozásához.

A katonai vezetési rendszer gyökeres átalakítása önmagában kevés lenne a fent vázolt cél eléréséhez tekintettel arra, hogy a puccsisták mögött egy jól meghatározható hálózat állt, melyet több évtizeden keresztül a nevelés és ezen belül a katonai nevelés segítségéveé épített ki a Hizmet mozgalom. Ez azt jelenti, hogy a civil kontroll megteremtése érdekében az államnak 
kell felügyelnie a tisztképzés teljes intézményrendszerét. Bár civil kontrollról van szó, az állam nem engedheti meg magának azt a luxust, hogy a civil társadalomra bízza ezt a szektort, hiszen az újabb párhuzamos állami struktúrák kiépüléséhez vezethet. Ennek a folyamatnak a keretében megszüntek a katonai középiskolák, valamint az eddig nagyfokú önállóságot élvező katonai felsőoktatási intézmények egy új Nemzetvédelmi Egyetem keretei között fuzionáltak. (HAUGOM, 2019, 6)

A fenti korlátozásokon és átszervezéseken túl néhány szervezetet és feladatkört a hadsereg kénytelen volt átadni a Belügyminisztériumnak. Itt leginkább arra kell gondolni, hogy ezentúl a belügyi kormányzat felügyeli a csendőrséget és a parti őrséget. A csendőrség klasszikus rendőri feladatokat lát el a rurális térségekben, míg a parti örség a politikai szerepvállalás helyett a 2015-ös menekültválság okán megnövekedett migrációs nyomás elleni védekezésre tudja az erejét fordítani. Mindez azt jelenti, hogy a török állam ezentúl hatékonyabban is tud müködni, hiszen a direkt politizálás helyett a katonák azzal törődhetnek, ami valójában az eredeti küldetésük. (HAUGOM, 2019, 6)

\subsubsection{A hadsereg posztmodern válasza: a 2007. április 27-i sajtónyilatkozat}

Az előző pontban leírtakból úgy tünhet, hogy a TSK minden ellenállás nélkül elfogadta a politika korlátozásait, és nem fejtett ki ellenállást kiváltságai védelmében, de korántsem ez a helyzet. 2002 óta több próbálkozás is történt a militarista restauráció hívei részéről. Az egyik legismertebb ezek közül a posztmodern puccsnak is aposztrofált 2007. április 27-ei sajtónyilatkozat, ami a fegyveres erők honlapján jelent meg, ám onnan két évvel később nyom nélkül eltávolították, és ma csupán a hírportálok archívumaiban olvashatjuk el.

A párt történeténél is már tárgyalt nyilatkozat dramatikus bevezetője után - amelyben arról értekeznek, hogy veszélyben a haza, a török zászló és a török politikai rendszer alapját képező szekuláris államrend, illetve meg nem nevezett személyeket azzal vádolnak, hogy a vallás leple alatt nőket és gyermekeket használnak ki - megtudhatjuk, hogy a hadsereg nemtetszését néhány kis jelentőségü, helyi jellegü rendezvény váltotta ki. A kifogásolt események között volt egy ankarai külvárosi Korán-olvasó fesztivál, amit eredetileg április 23-ára hirdettek meg, így egybeesett volna a nemzeti függetlenség és a Musztafa Kemál Atatürk által elrendelt gyermekek ünnepével, ám attól a szervezők a hatóságok nyomására elálltak. A délkelet-törökországi Şanlıurfában egy nappal a fenti, végül lefújt müsor előtt egy olyan rendezvényre került sor, ahol „korszerütlen ruhákban” istenes énekeket énekeltek olyan kislányok, ,akiknek akkor már rég 
az ágyukban lett volna a helye". A korszerütlen ruházat alatt nyilván arra kell gondolni, hogy a lányok fejkendőben voltak. Továbbiakban három iskolai megemlékezést támadtak a hadsereg részéről, melyek során megint előkerül az, hogy a lányok fejkendőt viseltek, és a tanulók kötelező részvétele mellett vallási tanítások és énekek hangzottak el.

A nyilatkozatot olvasó törökök persze megmosolyogták a szöveg azon kitételét, hogy ezek a programok veszélyeztetik a köztársaságot és az államberendezkedést, így ezek ellen tettekkel és nem csak szavakban kell fellépni. Ugyanakkor mindenkit átjárt a félelem, hiszen az 1980-as puccs idején is egy vidéki radikális tüntetésre történt hivatkozással léptek a katonák. Válaszul a kormány részéröl Cemil Çiçek szóvivő adott ki egy közleményt, amiben arra emlékeztetett, hogy a kormány kiáll Törökország szekuláris berendezkedése mellett. A politikai felbolydulásának eredménye az lett - és vélhetően ez volt a kezdeményezés célja is -, hogy sikertelennek bizonyult az ankarai parlamentben az elnökválasztás első fordulója, ugyanakkor kicsit később elnökké választották az AK Partihoz tartozó Abdullah Gült. Az esetet azzal foglalhatnánk legjobban össze, hogy a vezérkari fönök közleménye nem polgárháborút, hanem a demokráciákban megszokott nyilatkozatháborút indukált, és végleg megmutatta, hogy a hadsereg befolyása komolyan mérséklődött az elmúlt években. A szerencsétlen sajtónyilatkozat sokat ártott a katonaság tekintélyének, 2007 után azon kellett dolgoznia a katonai vezetőknek, hogy visszanyerjék a török nép beléjük vetett bizalmát.

\subsubsection{A 21. század katonai hátterü puccskísérletei}

A hadsereg 2007-es nyílt próbálkozása mellett volt több titkos hatalomátvételi kísérlet is Törökországban. 2004-ben négy ilyen, kisebb jelentőségü próbálkozást is lelepleztek (A Sarıkız-, az Ayışığı-, a Yakamoz- és az Eldiven-ügy). A tervek mögött a legfontosabb fegyvernemi vezetők álltak, akiket Özden Örnek, a tengerészet föparancsnoka fogott össze. A Recep Tayyip Erdoğan személye és kormánya ellen szervezkedők azért nem jártak sikerrel, mert az akkori vezérkari főnök, Hilmi Özkök lojális maradt a demokratikusan választott kormányhoz. Az esetről három évig nem szerezhetett tudomást a közvélemény. A puccskísérlet vezetőit, köztük az Atatürkista Gondolkodók Egyesületének elnökét, a csendőrséget is vezető Şener Eruygurt csupán 2008-ban vették örizetbe, mikor a később bemutatásra kerülő Ergenekon-ügy kezdett terebélyesedni. A török igazságszolgáltatás lassú válasza, a többéves várakozás mögött az állhat, hogy a hatalom abban bízhatott, hogy a hadsereg önként visszavonul, és nem kísérel meg újabb államcsínyt, ám a 2007-es nyilatkozat bebizonyította, hogy a veszély nem múlt el. 
A fent említett puccskísérletekhez hasonlóan a Balyoz-ügy is régi, ám csupán 2010-ben került a nagyobb nyilvánosság elé. A Taraf újság beszámolója szerint Çetin Doğan hadseregparancsnok vezetése alatt egy részletesen kidolgozott terv készült. Eszerint külön-külön vették volna örizetbe azokat a politikusokat, muszlim és nem-muszlim vallási vezetőket, értelmiségieket és jogvédőket, akikről azt gondolták, hogy szembeszegülnének a katonai hatalomátvétellel. Az elképzelés szerint Isztambul két történelmi dzsámijában, a Bejazidban és a Fatihban szerveztek volna bombamerényletet, a nemzetközi helyzetet pedig azzal mérgesítették volna el, hogy megrendezték volna egy török vadászgép lelövését a görög határ mentén, ezzel rákényszerítették volna a kormányt arra, hogy szükségállapotot vezessen be. Doğan a bíróság előtt azzal mentegetőzött, hogy nem puccskísérletről volt szó, csupán 2003 márciusában egy vészhelyzeti forgatókönyveket felvázoló szeminárium egyik gondolatmenetéről. A bírósági eljárás során 365 ember sorsa felől döntöttek. A puccskísérlet három legfőbb vezetője egyenként húszéves börtönbüntetést kapott.

A 21. század elejének puccskísérletei közül kétségtelenül az Ergenekon-ügy váltotta ki a legnagyobb közérdeklődést. A türk népek öshazájáról elnevezett, katonai hátterü, ultranacionalista összeesküvés a 2000-es évek számos törökországi erőszakcselekményéért felelős, ezért az „Ergenekon mozgalmat” joggal nevezhetjük terrorszervezetnek is. A legismertebb fegyveres támadások, melyek az Ergernekon számlájára írhatóak az Államtanács elleni 2006-os támadás, melynek során megölték az Államtanács egyik tagját, Mustafa Yücel Özbilgint. Ide soroljuk a 2007-ben az anatóliai Malatyában a keresztény Zirve kiadó elleni támadást is, melyben három személy vesztette életét, valamint a 2008-2009-es időszak több politikai merényletét. Ilyen merénylet volt az a Molotov-koktélos támadás, ami a Cumhuriyet címü napilap szerkesztőségét érte, illetve az a próbálkozás, mely Bartholomeosz ortodox pátriárka életét szerette volna kioltani.

Az Ergenekon, mint állam az államban már valószínüleg az 1990-es években is létezett. 1997-ben a Show TV egyik adásában kerül szóba először, hogy létezhet egy „párhuzamos állam”, melynek célja a török állam belülröl való destabilizálása. Az Ergenekon név azonban négy évvel később, 2001-ben került elő a titkosszolgálati dokumentumokban. Még ebben az évben a sajtóban is megjelenik az első írás, ami említést tesz arról, hogy a fegyveres erőkön belül egy Ergenekon nevü szervezkedés tevékenykedik. Az addig csak szóbeszédnek tartott összeesküvés-elméletet akkor kezdték komolyan venni a törökök, amikor Isztambul egyik ázsiai szegénynegyedében, az Ümraniye kerületben található Çakmak-negyedben egy házkutatás során tucatnyi kézigránát került elő. (A nyomozók eljutottak egy számítógéphez is, melyben jegyzeteket találtak arról, hogy az Ergenekon miként használta fel a tetőn már másfél 
éve tárolt robbanóanyag hiányzó részét. Később Törökország több más pontján, így Eskişehir városában is fegyverraktárakra bukkantak a rendörök.) Lassan összeállt a kép a terrorszervezetről, és 2007 júliusában, alig három hónappal a bizonyos sajtónyilatkozat után megkezdődtek a letartóztatások.

Másfél évvel a letartóztatási hullám után, 2008 októberében pedig az Isztambultól nyugatra fekvő Silivri börtönében és több egyéb bíróságon is megkezdődött a vezető tisztek, újságírók és egyéb értelmiségiek alkotta szervezet elleni per, amelynek következtében többek között İlker Başbuğ volt vezérkari fönököt életfogytiglani börtönbüntetéssel sújtották. „Törökországban kétségtelenül az Ergenekon-per volt a puccskísérletek tekintetében a legkritikusabb jogi eljárás" - jellemzi a helyzet komolyságát Gülçin Avşar. (AVSAR, 2013, 11) A nagyszabású nyomozás és a szigorú ítéletek a külföldi, így a magyar sajtó érdeklődésének homlokterébe emelték az eseményt. A perek - bár jogi folyamatokról beszélünk - hatással voltak a törvényhozó és a végrehajtó hatalomra is, „lehetővé tették az AK Parti számára, hogy megerősítse hatalmát a hadsereg és annak előléptetési rendszere felett”. (AKNUR, 2013, 140) A politikai pártok közötti harcokba is beleszóltak az eljárások, 2011-ben a választási küzdelem egyik fontos eleme az Ergenekon-ügy volt, ugyanakkor az AK Parti sikerrel tudta kommunikálni, hogy az ügyészség és a bíróság független, és nem az ellenzék elleni boszorkányüldözésről van itt szó. Így nem csupán hatalmát szilárdította meg, de a választási győzelemhez is közelebb vitte a pártot ez a per. (GÜRSOY, 2012, 19)

A Török Fegyveres Erők a többpártrendszer időszakában három sikeres és több sikertelen puccsal igyekeztek az ország sorsába beleavatkozni. A 2000-es évek elején a politikai elit megelégelte, hogy a katonaság a demokratikus átmenet kerékkötője, és így az európai integráció akadályozója, ezért az 1980-as államcsíny utáni struktúra átszervezését célozta meg. Ez a folyamat felgyorsult az AK Parti 2002-es hatalomra jutása után. A jogi lehetőségek csökkenése ellenére a TSK egy ideig nem mondott le régóta meglévő előjogairól, ám a 2007-es félresikerült sajtónyilatkozat és a sorozatos leleplezések és perek hatására „,megszelídült” és elfogadva a demokratikus játékszabályokat, beilleszkedni látszik az új török társadalomba, amelyhez az is hozzájárul, hogy az AK Parti kormányzása alatt bár csökkent a katonai költségvetés, komoly fejlesztések történtek a fegyverzet terén. 


\subsection{Az etnikai és vallási kisebbségek helyzete}

\subsubsection{A kisebbségek helyzete mint az európai integráció egyik előfeltétele}

„Míg Európában a történelem folyamán amint megváltozott valamely ország felett az uralom, úgy vált egyik vagy másik etnikum kisebbséggé az adott országban, és ily módon ott szükségessé vált a kisebbségi jogok garantálása, addig Anatóliában a függetlenségükért vállvetve harcoló népeket csak mesterségesen lehet „többségre” és kisebbségre” bontani” - véli Meral Atılgan egy 2006-ban megjelent cikkében. (ATILGAN, 2006, 44) Ez az idézet is jól példázza, hogy a kisebbségek megítélése gyökeresen más a klasszikus értelemben vett Európában és Törökországban. Az öreg kontinensen a középkorban és az újkorban zömmel kis területü államok álltak fenn, a 19. századtól kezdve ezek leginkább nemzetállami keretek között müködtek. Ezzel szemben a 13. és 14. évszázad fordulóján megszülető, és több száz évig fennmaradó Oszmán Birodalom nagy térségre terjesztette ki a hatalmát, vallási alapon kategorizálta az alattvalókat, nem csupán nem adott teret a nemzeti törekvéseknek, beleértve a török nemzeti törekvéseket is, hanem egy egyfajta egységesítő erőként hatott. Kialakult az oszmán identitás, ami mellett, vagy éppenséggel alatta, sokáig nem tünt fontosnak az etnikai hovatartozásból fakadó másodlagos önazonosság-tudat. Ez azt jelenti, hogy még a mai török átlagember számára is nehezen értelmezhető az etnikai kisebbség fogalma, főleg nem tud mit kezdeni a kisebbségi jogok garantálásának európai igényével. Ugyanakkor a kisebbségi jogok tiszteletben tartása az európai joganyag egyik fontos pillére, annak elfogadásán, és a török néppel való elfogadtatásán keresztül vezet az út Európába.

A kisebbségi jogok elismerésének fontossága a kétpólusú világrend felbomlása után, azaz 1990-től kezdve került az Európai Unió érdeklődésének homlokterébe - érvel Taşdemir és Saraçl1 -, amikor is a régi, az emberi jogok általános értelmezésén alapuló szemléletet felváltotta egy új nézőpont, amelynek kialakulásához a Szovjetunió, Csehszlovákia és Jugoszlávia felbomlása vezetett. (TASDEMIR-SARACLI, 2007, 28) Polgárháborúk és fegyveres konfliktusok egész hosszú sora söpört végig Közép- és Kelet-Európán, az addig az abban a régióban mellőzött kisebbségi ügy elementáris erővel tört elő. A Római Szerződés aláírása óta gazdasági értelemben egyre egységesebb Európát megrémisztette az, hogy a multietnikus államalakulatok széteséséhez vezethet az etnikai feszültség. Ez a „pánik” vezetett oda, hogy az európai vezetők a kisebbségi kérdések rendezését az unió további bővítése egyik sarokkövének kezdték tekinteni. Az európai országok közül Ausztria és Németország azt a nézetet képviselte, hogy a kisebbségeket megilleti a nyelvi, a kulturális és a vallási autonómia, illetve azokban a 
régiókban, ahol többséget alkot a kisebbség, az önrendelkezés joga. Vagyis készek voltak kollektív jogokat is garantálni, szemben például a centralizáció és klasszikus homogén nemzetállami modellt képviselő Franciaországgal, amely ódzkodik mindenféle kisebbségi csoportjog elismerésétől. Ezzel szemben a franciák és a görögök a kisebbségi jogokat az állam területi egységének megörzése alá rendelték volna. Az ekkor még szintén tagjelölt Magyarország álláspontja az első felfogáshoz állt közelebb, 1994-ben települési szinten autonómiát biztosított az ország az elismert kisebbségeknek. 1992-ben az Európa Tanács egyes tagországai létrehozták a Regionális és kisebbségi nyelvek európai kartáját, amit azóta összesen 24 ország írt alá. Törökország - bár tagja az Európa Tanácsnak - nincs az aláírók között, ám a török nyelv védelmet élvez Romániában. Ez a példa is jól mutatja, hogy nem minden európai ország áll ki egységesen a területén élő kisebbségek jogai mellett, és nem minden esetben érzékelhető a reciprocitás, azaz a kölcsönösség elve.

Bár a kisebbségi ügyekben máig sem egységes Európa, az új belépőktől elvárja a területükön élő kisebbségek jogainak garantálását. Törökország esetében ez azt jelenti, hogy az európai felfogás teljes adaptációja válik szükségessé. Mint már említettük, az oszmánok idején csak vallási kisebbségekről tett említést a korabeli jogrend, mely az örmény és görög ortodoxokat és a zsidókat ismerte el önálló jogalanyként. Nemzetiségi kisebbségekről először a török politika az I. világháborút lezáró békekötések során beszél, az első dokumentum pedig, ahol egy csoport jogainak garantálása is említésre kerül, az 1925-ös török-bolgár barátsági megállapodás, melynek keretei között a fiatal Török Köztársaság vállalta a területén, elsősorban Edirne környékén élő bolgárok jogainak biztosítását, cserébe a Bulgáriában lakó, sokkal népesebb török közösség jogaiért. (TASDEMIR-SARACLI, 2007, 32) 1935-ben pedig Musztafa Kemál Atatürk, a köztársaság alapítója garantált helyeket biztosított a nemzetgyülésben a nemzeti kisebbségek képviselői számára. Ekkor két görög, egy örmény, egy ortodox vallású török és egy zsidó küldött ülhetett be az ankarai padsorokba.

Az Európai Unió 1999-ben Helsinkiben összeülő állam- és kormányföi arra szólították fel a tagságra váró Törökországot, hogy a kisebbségi kérdésben is tartsa be az ún. koppenhágai kritériumokat, azaz a csatlakozás feltételeit. 1993 júniusában az Európai Tanács a következőket fogalmazta meg: ,a tagjelölti státusz azt jelenti, hogy az ország a demokrácia müködése érdekében elérte az intézményrendszer stabilitását; jogállam, amely garantálja az emberi- és kisebbségi jogok érvényesülését; olyan piacgazdaság, amely képes versenyezni az unión belüli piac többi szereplőjével.” (PRESIDENCY CONCLUSIONS) Ennek érdekében 2001-ben, tehát még Bülent Ecevit koalíciós kormányzása idején egy alkotmányreformot szavazott meg a Nagy Török Nemzetgyülés, amelynek következtében lehetővé vált a kisebbségi nyelvek és 
dialektusok használata az állampolgárok magánszféráján túl a hírközlésben is. Későbbiekben látni fogjuk, hogy az AK Parti kormányzása idején ezek a jogok gyakorlattá váltak (több évet kellett az első kurd és más nyelvü TV-adók beindulásáig várni), és kiterjesztették őket az élet több más területére, így az oktatásra is.

\subsubsection{A kurd-kérdés}

A mai Törökország összes kisebbsége közül a kurd a legnépesebb, épp ezért ők rendelkeznek a legnagyobb önmegvalósítási potenciállal a társadalmon belül. A kurdok helyzete a török társadalom fokmérője: szabadságuk pedig az európai integráció záloga.

A kurdoknak az egyik legemblematikusabb képviselője a közelmúltban eltávozott Yaşar Kemal volt. Hassanpour és Mojab a Diaszpórák lexikonában (EMBER-EMBER-SKOGGARD, 2005, 2014) azt írja, hogy az arabok, a törökök és a perzsák után ők alkotják a Közel-Kelet negyedik legnagyobb etnikai közösségét. Számuk 27,1 millió főre tehető, ebből a szerzőpáros szerint mintegy 13,7 millió él Törökországban, zömmel annak délkeleti, az iráni, az iraki és a szír határvidéken fekvő megyéiben. A szakirodalomban Hassanpour és Mojab becslésétől mind felfele, mind pedig lefele számos egyéb adat is szerepel, ezért nagyon nehéz pontosan meghatározni a törökországi kurdok számát és arányát. Ennek az egyik legföbb oka az, hogy 1965 óta a török statisztikai hivatal (TÜIK) nem kérdez rá a polgárok etnikai hovatartozására, hanem csak matematikai módszerekkel igyekszik felmérni egy-egy népcsoport súlyát. Az utolsó akkurátus adatok tehát 1965-ből származnak, ekkor a kurdok számaránya 10\% volt Törökországban. A Diaszpórák lexikonjának szerzőivel szemben a régi népszámlálási adatok aktualizálásával operáló szerzők jóval konzervatívabb értékeket kapnak, ők 6 és 12,6\% közé teszik a törökországi kurd kisebbség arányát. (SIRKECI, 2000, 154) Ha a becslések helytállóak, akkor a kurd etnikum Törökországban komoly tényező, az ország egyensúlya és biztonsága nem szavatolható az ő együttmüködésük, a békés török-kurd együttélés nélkül. Ez a kézenfekvőnek tűnő megállapítás azonban egy szerves fejlődés révén vált a török közélet és közgondolkodás sajátjává.

\subsubsection{A kurdok helyzete az Oszmán Birodalomban}

A Török Köztársaság és a közel-keleti nacionalizmusok virágzása előtt, az Oszmán Birodalom idején hosszú ideig békésen élt együtt több etnikum Anatóliában. Ezen néptömegek közé tartoztak a kurdok is. Hakan Özoğlu is megemlíti, hogy ezekben az időkben, különösképpen a 
17. században még az etnikai különállás és a szeparatizmus minden felhangja nélkül, rendszeresen használták a kurd és a Kurdisztán szavakat. (ÖZOGLU, 2004, 47) Özoğlu szerint így tett a törökök híres világutazója Evliya Çelebi is a nevezetes Seyahatnaméjában, aminek kortárs török kiadásaiból „,kifelejtették” ezeket a kifejezéseket, amelyeket azonban megtalálunk a nyugati nyelveken írt fordításokban. Jó példája ez annak, hogy amíg a késő középkori ember számára az etnikai identitást felülírta a vallási hovatartozás, addig a közelmúlt Törökországában mindez éppen fordítva volt. A 19. századra a Kurdisztán kifejezés annyira elterjedtté vált, hogy az állam arról döntött, hogy Kelet-Anatólia egyik legnagyobb területü tartományát Kurdisztán ejáletinek, azaz Kurdisztáni tartománynak nevezzék el. (ÖZOGLU, 2004, 51) Ekkor persze még nem voltak fogékonyak a kurdok a nyugati gondolatokra, nem jellemezte öket sem a gellneri értelemben vett politikai, sem az etnikai alapú nacionalizmus, (GELLNER, 1983) független államra, területi autonómiára nem vágytak; a Kurdisztán szót csupán egy néphez kötődő területmegnevezésként értelmezték. A kurd identitás, az összetartozás érzése és a nemzettudat a század végén erősödött meg. A nagyhatású költő és vallási vezető, Hadzsi Kádir Koji gondolatiságát használó kurd nacionalizmus az I. világháború idejére teljesedett ki, amikor is szemben találta magát számos rivális nemzetállami törekvéssel, elsősorban az oszmán területek romjain megalakulni készülö örmény állam híveinek elképzeléseivel. A háború végeztével, a Párizs-környéki békék megkötése idején már határozott elképzeléseket vázoltak fel a kurd nacionalisták: a kurdokat képviselő Şerif pasának végül sikerült elméletben megegyeznie az örmény delegáció fejével, Bogosz Nubárral arról, hogyan is osszák fel az eddig a törökök által ellenőrzött kelet-anatóliai területeket. (ÖZOGLU, 2004, 55) Az egyre komolyabb igényeket támasztó kurd nemzeti függetlenségi mozgalmat a Nyugat ihlette, és végül a Nyugat volt az is, aki nem teljesítette a kurdok azon kérését, hogy a „világ legnagyobb hazátlan nemzete" valahol mégis otthonra leljen.

Egy más megközelítést alkalmazva azt is mondhatjuk, hogy a kurd nemzeti öntudatra ébredés - Özoğlu meggyőződésével szemben - jóval régebbi időpontra tehető, hiszen már Ahmed Kháni 17. századi kurd költő műveiben is felbukkanó téma. Kháni valóban „árvának” nevezte saját nemzetét, de ezt azzal indokolta, hogy nincs olyan uralkodó, aki felkarolná a kurdok ügyét. Ez pedig azt jelenti, hogy a korai kurd ébredés nem volt modern értelemben vett nacionalizmus, hanem a jelenséget egyfajta etnikai elemhez kötött birodalmi törekvésként értékelhetjük. Kháni müveiben azért egy újszerü vonást mindenképpen felfedezhetünk: kortársaival szemben nem vallási, hanem etnikai kategóriákban gondolkodott, és ez egyedülálló volt a korabeli Közel-Keleten. Kháni vélekedése ugyanakkor elszigetelt jelenség maradt, a kurdok többsége inkább azokra a vezetőire hallgatott, mint Idrisz-i Bitliszi, aki a kurd nemesség 
követeként Szelim szultán udvarában hamar egyezségre jutott a padisahhal, mert közös nevező volt közöttük, az Ittihad-ı Islam, azaz az iszlám egység. Ez tehát azt jelenti, hogy az identitás vallási oldala hosszú ideig felülírta az etnikai és nyelvi elemet. (MENEK, 2013, 13-14)

\subsubsection{A kurd kérdés kezelése a Köztársaság megalakulása után}

A törökség rovására erősödő kurd függetlenségi törekvések kiváltották a többségi társadalom nemtetszését, illetve azt eredményezték, hogy a törökök nem csupán ellenezték azokat, de beszélni sem volt ildomos a kurdokról. Az atatürki reformok egy új politikai nemzet létrehozását célozták meg, amelybe beletartozott az etnikai és származásbeli különbség elfedése ugyanúgy, mint az oszmán kori népi és vallásos kultúra háttérbe szorulása. Az egyre erősödő török nacionalizmus ideológiai megalapozói - mint arra Abdulkadir Menek is rámutat - sokszor kurd származásúak. Ilyen volt a fiatalon elhunyt Ziya Gökalp, akinek az édesapja félig zaza, félig kurd származású volt, hasonlóképpen etnikai szempontból vegyes származásúnak tekinthető Dr. Abdullah Cevdet is, aki a későbbiekben vezette a török nacionalistákat. (MENEK, 2013, 80) Tehát az atatürki reformokat megalapozó nemzeti gondolat kiötlői részben kurdok voltak, de egy pántörök eszmében hittek, amelyben a kurd hovatartozású is lehet török. Ez a gondolat radikálisan átszabta az oszmán status quo-t. A mindenkit egyesítő vallási örökség, a kisebbség és a többség életét szabályozó iszlám jogrend helyébe egy új összetartó elem lépett. Ez az etnikai határokat figyelmen kívül hagyó, a politikai nemzethez és az új köztársasághoz való ragaszkodáson alapuló nacionalizmus egyrészt lehetőséget adott a Gökalphoz és a Cevdethez hasonló kisebbséghez tartozó személyeknek arra, hogy feledve származásukat felemelkedjenek, de nem találkozott a kurd tömegek többségének akaratával, hiszen a keletanatóliaiak a központi területek lakóinál jóval hagyományőrzőbbek, konzervatívabbak és vallásosabbak voltak.

A gökalpi és cevdeti nacionalizmus ellen csakhamar megszületett a reakció, ami kezdetben nem etnikai, hanem vallási jellegü volt. Az egyik legjelentősebb ellenállási mozgalmat ebben a korai korszakban a Sejh Szaid által vezetett felkelés jelentette. Bár a kurd függetlenséget tüzte zászlajára, Sejh Szaid a kalifátus eltörlése ellen lázította fel népét a mai Bingöl megyében fekvő Genç környékén, - ami akkoriban egy önálló tartomány volt - a felkelés hívószava pedig az iszlám vallás megvédése volt. Sejh Szaidot az atatürki államvezetés kivégezte, és hasonló sorsra jutott több más lázadóvezér is, akik rendre vallási követelésekkel, és nem nacionalista elvárásokkal álltak elő. (ASGIN, 2001) Ezért lehet Vidáknak igaza, amikor így összegez azzal kapcsolatban, hogy miért is csalódtak a kurdok a köztársaságban annak kikiáltása után néhány 
évvel: „a török politika intézkedései a kurdok ellen egyre agresszívebbek lettek, és még minimális szinten sem szolgálták a kurdok érdekeit.” (VIDÁK, 2007, 49)

Az 1920-as évek közepére minden vallási indíttatású kurd vagy nem kurd mozgalmat sikeresen levert az atatürki rendszer. A köztársaság konszolidációs időszakon ment keresztül, melynek során véghezvittek közigazgatási reformokat is, de nem történt meg az, amire Atatürk még 1922-ben ígéretet tett, amikor miniszterei előtt még így beszélt: ,,a kurdok lakta régiókban pedig lépésről-lépésre kénytelenek leszünk bevezetni a helyi önrendelkezésen alapuló közigazgatást”. (TOPDEMIR, 2014, 134) Egy későbbi beszédében az államalapító már így értékeli a két etnikum jövőjét: „a Nagy Török Nemzetgyülés (TBMM) most már mind a törökök, mind a kurdok képviselőiből áll, és ez egyesíti a két nép törvényhozását és sorsát. Tehát ők is tudják, hogy ez egy közös ügy. Nem lenne helyes külön-külön jövőt meghatározni ennek a közösségnek” (TOPDEMIR, 2014, 134) A kezdeti engedékeny hangnem egyértelmü elutasítássá válik. Atatürk nem hagyott kétséget afelől, hogy nem támogatja a kurdok önállósulását. Az autonómia elutasítása egyre erőteljesebb ellenkezést, végül nyílt fegyveres konfliktust eredményezett. 1937-ben és 1938-ban mintegy 13.000 ember, zömmel civilek, vesztették életüket a véres dersimi (tunceli) felkelésben, amelyet követően számos jogfosztás érte a kurdokat, így például a lázadásnak helyet adó régió is új nevet kapott: Dersimből Tunceli lett.

A többpárti demokrácia kiépülése és a demokratikus választások rendszeressé válásával a törökországi kurdok jelentősége felértékelődött. Ha a fejezetünk elején szereplő becslés pontos, azaz az ország lakóinak 6-12\%-a tényleg a kurd etnikumhoz tartozik, akkor a voksolások sorsát is eldönteni képes, Törökország jövőjét is döntő módon befolyásoló választói csoportról van. Ezt a török politikai pártok fokozatosan ismerték fel. Eleinte egy-egy kurd származású politikus vállalta fel érdekeik védelmét, majd megjelentek, és gyakran hamar megszüntek olyan formációk, melyeket a közvélemény a kurd kisebbséghez kötött és föleg a délkeleti országrészben és a nagyvárosok kurd migránsai által lakott negyedeiben szerepelt sikeresen. Ezek a kurdokhoz köthető, de nevükben vagy programjukban időnként össztörök célokat is meghirdető csoportok eltérő ideológiai háttérrel rendelkeztek. Voltak olyanok, amelyek marxista, vagy nemzeti jellegü, vagy vallási tematikájú politikai stratégiát követtek. Az AK Parti volt azonban az első olyan török párt, amely felismerte, hogy a kurdokat úgy is lehet képviselni, hogy miközben elismerik létüket, lehetővé teszik sajátos kulturális igényeik kielégítését, és tesznek a jólétükért, integrálják őket a török nemzetbe. Mivel a kurdok lakta vidékek hagyományosan vallásosabbak és konzervatívabbak, ezért ezzel a megközelítéssel a kurd hátterü választók többsége megnyerhetőnek tünt. Ezen politikai megközelítés akkor 
találhat konkurenciára, ha egy kurd nemzeti párt jelenik meg szeparatizmustól mentes, vallásos és konzervatív programmal. Egyes megfigyelők szerint ilyen lehet a 2012-ben életre hívott Szabad Ügy Pártrja (Hüda Par).

\subsubsection{Az AK Parti nemzetfelfogása}

Az AK Parti tehát lehetőséget látott a kurdokban, a kurd szavazók egy része pedig elfogadta az AK Parti által javasolt politikai víziót, mely szerint a köztársaság kikiáltásának 100. évfordulójára, azaz 2023-ra Törökország a világ egyik vezető gazdasági ereje lesz, és ennek köszönhetően az ő térségük is jelentős fejlődésen mehet keresztül. Az ambiciózus gazdasági tervek megvalósításához politikai támogatásra, a kurdok megnyeréséhez pedig a török politikai nemzetről vallottak átgondolására volt szükség. Az AK Parti újnak mondható török nemzetfelfogásáról a 2012-es alkotmányreform idején is élénk vita bontakozott ki. A török nemzetről való együttgondolkodást Ahmet Küçükler erzurumi kormánypárti polgármester indította meg azzal, hogy egy nagygyülésen kijelentette, hogy Törökország „Egy nemzet, egy állam, egy zászló”. (BAKIRCI, 2012) Az ellenzéki támadások kereszttüzébe került városvezető mellett egyből kiállt Recep Tayyip Erdoğan akkori kormányfö, aki az összetartozás alapvetéseinek számát háromról négyre emelve a közös vallást is megemlítette. A miniszterelnök ki is fejtette, hogy mindezen azt érti, hogy szembe helyezkednek a megosztókkal és azokkal, aki feldarabolnák az országot. Hozzátette, hogy nem teszi lehetővé, hogy éket verjenek a többségi törökség és a kisebbségek, így a kurdok, a lázok, a cserkeszek, a grúzok, a romák, a bosnyákok és az albánok közé. (HABER MERKEZI, 2012) Az összetartás szükségessége mögött egyébként egy vallási eredetű gondolat is meghúzódik, hiszen a fenti megnyilatkozását Erdoğan azzal zárja, hogy „,mi a teremtményeket a Teremtőért szeretjük, ezért nem lehet széthúzás”. A fitna, a széthúzás -mint ahogy arról az iszlám szent könyve, a Korán is megemlékezik a 2. szúra 191. ájájában- pedig az iszlám vallás szerint az emberölésnél is nagyobb bün. Az Erdoğant hallgatók ebből azt a következtetést vonhatták le, hogy az AK Parti egy olyan nemzetben hisz, mely egységes a céljaiban, de sokféle etnikumból áll, az pedig, aki ezt az egységes nemzetet tagadja, az megbontja azt a konszenzust, ami a nagy nemzeti fejlesztési tervek véghezviteléhez feltétlenül szükséges.

Az egységes török nemzet és az egységes török állam ahhoz is kell, hogy az AK Parti tervei szerint fokozatosan erősödő és gazdagodó Törökország valós hatalmi tényezővé váljon nemcsak a Közel-Keleten, hanem a Balkánon és a kaukázusi vidékeken is. A regionális hatalmi szerepre aspiráló ország új nemzetfelfogását egyes kutatók - mint Cüneyt Ülsever- úgy mutatják 
be, hogy ez több annál, ami egy klasszikus nemzetállamot jellemez. (ÜLSEVER, 2011) Birodalmi nosztalgia által táplált gondolkodásmód ez, amit a yeni osmancılıkként, azaz új oszmánizmusként írnak le. Zgut Edit egyenesen azzal vádolja a Heti Válaszban megjelent cikkében a török kormányt, hogy a „múltba vezeti vissza az Új Törökországot”. (ZGUT, 2015) Zgut szerint „az egyre konzervatívabb tónusban politizáló, iszlamista Erdogan mintha valóban az oszmán birodalmi öntudatot igyekezne restaurálni a kemalista hagyományok fokozatos háttérbe szorításával." Tagadhatatlan, hogy Törökországban komoly érdeklődés mutatkozik az oszmán múlt iránt. Tény az is, hogy divatba jött a kor öltözéke, zenéje, az oszmán-török nyelvet pedig bevezették választható tantárgyként a középiskolákban. Ám ez a nosztalgia nem korszerütlen visszarévedezés a múltba, hanem egy olyan nemzeti egység felé tett lépés, ahol a régi kultúra újrafelfedezése segít a sokszínüség elfogadásában. Az, amit Zgut birodalmi öntudatnak vél, egy modern multietnikus nemzetállamban a békés együttélés záloga.

Az AK Parti nemzetfelfogása szerint tehát egy olyan politikai nemzet a törökség, ahol mindenki török, mert a közös célért tesz, és törökké azért lesz, mert török állampolgár, a török nemzet jövőbeli sikere pedig elválaszthatatlan a múltbeli nagyságától, az oszmán kulturális örökségtől. E két nézet pedig elvezet minket ezen nemzetfelfogás harmadik eleméhez, az etnonacionalizmus tagadásához, mert az automatikusan szemben áll az előző kettővel. Ezt fejezi ki az alkotmány preambulumának szövege is, ami szerint „mindenféle széthúzást elutasítva, a nyelvi és vallási különbségeket tiszteletben tartva az együttélés szándékát kinyilvánítva cselekvő török nép" az államalkotó. Ez a megfogalmazás is a széthúzás hiányát és a közös cselekvést hangsúlyozza, mint az egységes, de a különbségeket is tiszteletben tartó török nemzetállam alapját.

\subsubsection{A kurd nyitás}

Az AK Parti 2002-es hatalomra jutása után az új nemzetfelfogás mentén óvatosan, de a változás felé lépett. „Ígéreteinek megfelelően a kormány több „reformintézkedést” foganatosított, azonban ezek messze álltak attól, hogy rendezzék a kurd kérdést.” - véli Egeresi Zoltán. (EGERESI, 2011, 41) A rendezés azonban 2004-ben kétség kívül megkezdődött, a 2009-ben felgyorsuló folyamatot a politikatudomány a Kürt açılımı, azaz kurd nyitás névvel jelöli.

A kurd nyitás legnevezetesebb eseményei között elsősorban a kurd nyelvhasználathoz köthető könnyítéseket találunk. 2004. március 23-án engedélyezték az ország első kurd nyelvü TV- és rádióállomását, a Günt, ami két évvel később, 2006-ban kezdte meg a kurd nyelv kurmandzsi dialektusában megszólítani közönségét. Törökország történetében ez volt az első 
olyan eset, hogy egy kisebbség nyelvén elektronikus médiatartalom készülhetett. 2009-ben az állami TV is beindított egy kurd nyelvü adót TRT6 néven, sőt 2010-ben a ma kormánykritikusnak mondható Dünya TV is kurd nyelven kezdett sugározni a délkelettörökországi Gaziantepből. A kurdok egyébként számos más, Angliából, Dániából, Svédországból vagy éppen Irakból sugárzó kurd nyelvü műholdas adást is követhetnek. Miután népszerűvé váltak a kurd adók, más kisebbségi nyelvek használói is saját TV-csatornáknak örülhetnek. A TV 10 2011-től például zazául, a Gelişim 2014-től lázul fogott bele a müsorszolgáltatásba.

A kurd nyelv térnyerését mutatja az is, hogy a kurd „választható idegen nyelvként” 2012ben bekerült az oktatási minisztérium által kidolgozott új tantervbe is. Ez azt jelenti, hogy az a középiskolás diák vagy gimnazista (a török oktatási rendszer három négyéves ciklusból áll, a középiskola a második négy év, a magyarországi felső tagozatnak felel meg), aki nem szeretne például angolul tanulni, az hetente három-négy kurd nyelvórát vehet az állami iskolákban. Beşir Atalay a döntés bejelentésekor arról beszélt, hogy az állam felelősségi körébe tartozik a polgárai anyanyelvi oktatásának biztosítása. Gondot jelentett eleinte ugyanakkor, hogy nem léteztek kurd nyelvű taneszközök és oktatási segédanyagok, illetve még nem gondoskodtak a kurd nyelvtanárok képzéséről sem, tehát a kezdeti időszakban a kurd anyanyelvü oktatók lelkesedésére épített a rendszer. 2014 szeptemberében Diyarbakırban megkezdte működését az első teljesen kurd nyelvü általános iskola is. Az egyesületi formában müködő, az Iránban politikai nézetei miatt kivégzett tanárról elnevezett Ferzad Kemanger Általános Iskola száz kisdiákot oktat a török állami kerettanterv szerint, ám kurd nyelvü tankönyvekböl.

A kurd nyelvhasználat elősegítése terén a müvelődés és az oktatás mellett megemlítendő a kurd földrajzi nevek újbóli engedélyezésének szándéka. Az AK Parti 2013-ben vetette fel, hogy a kurdok lakta délkelet-anatóliai megyék közül 6, a járások közül pedig 12 használhatja a kurd nevét, beleértve azt is, hogy a kurd nyelvben gyakori, ám a törökben ismeretlen betűk, a "w”, $a z$ " $x$ " és a " $q$ " is szerepelhet bennük.

A nyitás túlmutat azon, hogy a kurd nép a nyelvét egyre szabadabban használhatja, s az egész török nemzetre kiható demokratizálási folyamatot indított be, amelynek - Egeresi szavaival élve - „több dimenziója van, melynek csak egyike a kurd”. Az „alevi nyitás”, a „roma kezdeményezés", a kisebbségekkel történő megegyezés, az EU-konform szabályozás a nemzetiségi kérdésben a korábbi időszakokhoz, és a török nemzetállami tradícióhoz képest hatalmas előrehaladást jelent." (EGERESI, 2011, 45)

A kurd nyitás tempójával azonban nem tudott lépést tartani a török társadalom egésze. Egy, a legnépesebb kurdok által is lakott városban, a délkelet-törökországi Diyarbakırban rendezett 
demonstráción a kormányfo azzal lepte meg hallgatóságát, hogy a „Kurdisztán” szót is használta. Ez sok török számára szinte szentségtöréssel volt egyenértékü, hiszen olyan volt ez, mintha elismerte volna a régió önálló államiságát. Két izmiri polgár még fel is jelentette Erdoğant, akit azzal vádoltak meg, hogy a „haza oszthatatlansága” ellen beszélt. A vádat végül bűncselekmény hiányában ejtették. Jellemző volt az is, hogy az eseményről tudósító állami média igyekezett átírni a miniszterelnök beszédét, a TRT állami televízió a „Kurdisztán” szó helyett „Észak-Iraki Kurd Régiót” használt a híranyagaiban. Mindez azt mutatja, hogy Erdoğan szóhasználatával is szerette volna a török közgondolkodást átalakítani, illetve a török-kurd közeledést elősegíteni, hiszen világos, hogyha a jogok megadása nem jár a többség tudati átalakulásával, akkor a fejlődés nem lehet tartós.

\subsubsection{A török-kurd viszonyt terhelö problémák}

A törökök és a kurdok együttélését ugyanakkor beárnyékolja egy-két szomorú vagy vitatott eset. Az egyik ilyen az Uludere- vagy Roboszki-ügy néven ismertté vált katonai akció, melynek során 2011. december 28-án mintegy negyven török állampolgárságú kurd személyt, gyakorlatilag egy nagy família tagjait lötték le török harci gépek az iraki-török határon. Az amerikai titkosszolgálati információkra alapozó török hadsereg úgy vélte, hogy a határon illegálisan átlépő csoport tagjai a szélsőbaloldali kurd terrorszervezet, a Kurd Munkáspárt (PKK) tagjai voltak, akik épp fegyvert szállítottak a háborús térségböl Törökországba. Később kiderült, hogy olyan helyi kurdok voltak, akik már hosszú évek óta csempészetből tartották fenn magukat. A török geostratégák két gyors következtetést is levontak az esetből. Egyrészt azt hangsúlyozták, hogy bár a csempészet bün, de annak a büntetése nem a halál, tehát egy ilyen, emberéleteket követelő tévedés esetén a török állam köteles elnézést kérni a kurdoktól, akiknek a hozzátartozóit kártalanítani is kell. Másrészt annak szükségességét emelték ki, hogy a török titkosszolgálatoknak többet kellene tudniuk a PKK tevékenységéről, hogy emiatt ne a kurd polgári lakosság szenvedjen, és a terrorszervezet ne kezdhessen bele újra a ,a török katonaság a kurdokat lövi” típusú propagandába.

A fenti véres esemény is jól példázza, hogy a török-kurd kapcsolatok megoldása útjában elsősorban két akadály áll: a szegénység és a terrorizmus. Ez a kettő pedig összefügg. Ha az előbbit lehet enyhíteni, akkor az utóbbi is kezelhetővé válhat. A szegénység felszámolása nem etnikai kérdés, és részét képezi a török kormánypárt távlati terveinek. Ha 2023-ra tényleg meghatározó világpolitikai és gazdasági szereplö szeretne Törökország lenni, akkor fejleszteni kell Kelet- és Délkelet-Anatólia infrastruktúráját, javítani a foglalkoztatási mutatókat, jelentős 
mértékben növelni a terület vonzerejét a külföldi befektetők számára, hiszen a legkevesebb müködő tőke - nem meglepő módon - a szíriai és az iráni határvidék megyéibe érkezik Şanlıurfától Ardahánig.

A szegénység a Kurd Munkáspárt, a PKK létrejötte mögött is felfedezhető. A ma is börtönbüntetését töltő alapító, Abdullah Öcalan egyetemista korában inkább a különböző marxista és kommunista vezetők befolyása alatt állt, illetve első szélsőbaloldali ifjúsági csoportja sem etnikai színezetü volt, hiszen abban több török nemzetiségü fiatal is vezető szerephez jutott. (ÖZCAN, 2012, 76-78) Az egyik ilyen töröknek, „Haki Karernek egy rivális kurd baloldali csoport általi 1977-es meggyilkolása felgyorsította a pártszerveződést, s 1978. október 27-én, egy Diyarbakir melletti kis faluban, Partiya Karkerên Kurdistan néven, megalakították a Kurd Munkáspártot.” (EGERESI, 2012, 97) A PKK egyre militánsabbá vált, majd 1984-ben megkezdte fegyveres harcát a központi kormány ellen. Eleinte rendőrörsöket támadtak meg, majd a civil lakosságot is megcélozták. Ankara ezzel a folyamattal szemben felfegyverezte az érintett térség falvainak lakóit kinevezve őket geçici ve gönüllü köy korucularınak, azaz átmeneti és önkéntes faluvédőknek. A terroristák, a faluvédők és a rendfenntartó szervek közötti folytonos harcoknak az évek során több tízezer áldozata lett. A PKK - hasonlóan a nigériai Boko Haram terrorszervezethez - az oktatási intézményeket sem kímélte. „A PKK célpontjai közé kerültek a törökökkel lepaktáló kurdok és a központi hatalom asszimilációs törekvéseit megtestesítő helyi iskolák is.” (EGERESI, 2012, 99) Öcalant 1998ban elfogták, előbb halálra ítélték, később ezt az ítéletet életfogytiglani börtönbüntetésre változtatták. Ez Öcalant is fordulatra késztette. A harcok beszüntetésére szólított fel, illetve fokozatosan elvetette a szeparatizmus gondolatát, és a demokratikus Törökországban a kurdok és a törökök egyenrangúságát jelölte meg céljaként. (ÖCALAN, 2012)

Bár a török állam már hamarabb is kereste a lehetőséget a letartóztatott terroristavezérrel és a hegyekben tartózkodó terroristákkal való párbeszédre, a békés rendezés előkészítése csupán az AK Parti idején, 2006-ban indulhatott meg. A kezdeti erőfeszítések nem vezettek eredményre, sőt Öcalan a titkos tárgyalások révén még utasításokat is tudott beépített emberein keresztül küldeni a terroristáknak. Ez arra késztette az Igazságügyi Minisztériumot, hogy megváltoztassa az Öcalant fogvatartó fegyintézmény, az İmralı jogi besorolását, és lecserélték a teljes személyzetet. A zárt egyezkedésekről 2011-ben szivárgott ki az első hírügynökségi jelentés, ami komoly felzúdulást eredményezett az ún. Mély $P K K$, azaz a fegyveres harcot folytatni szándékozó belső ellenzék körében. Később az is kiderült, hogy a török titkosszolgálat küldöttsége 2009 februárjában már egyszer Washingtonban találkozott a terrorszervezet szabadlábon lévő vezetőivel, illetve megkezdték a hegyekben tartózkodó gerillavezérek 
megkörnyékezését is. Mindeközben megindult a PKK szervezeti elfogadása is. „A békefolyamat megindítására nagy nyilvánosság előtt, de facto 2013. január 3-án került sor, amikor a Béke és Demokrácia Pártjának egy képviselője, Ayla Akat Ata, illetve a párt volt elnöke, a törökországi kurd közösség befolyásos alakja, jelenleg a Demokratikus Társadalom Kongresszusának (Demokratik Toplum Kongresi, DTK) vezetője, Ahmet Türk Öcalannál tett látogatást.” (EGERESI, 2013, 8)

Az AK Parti kurd nyitása erősítette a fent részletezett békülési folyamatot, amit a török értelmiség is támogatott. A megfogalmazott cél az volt, hogy a „PKK jöjjön le a hegyekből”. A kérdéssel részletesen is foglalkozó, a kormánynak jelentést készítő Cengiz Çandar arra a következtetésre jutott, hogy bár tagadhatatlanul léteznek társadalmi és politikai problémák a törökországi kurd lakosság tekintetében, a hegyekből való lejövetelnek egy motorja lehet: ha erre Öcalan személyesen ad parancsot. (CANDAR, 2001, 69) Çandar azzal érvel, hogy a terroristavezér által befolyásolt kurdok körében erősen él egy ún. kurd szentháromság, (CANDAR, 2001, 47) egyaránt tisztelik Öcalant, a PKK-t és a hegyeket. Ha sikerül ezt a „marxista” hitrendszert megingatni, akkor lehet más megoldás is, így viszont csak az maradhat hátra, hogy a kormány ráveszi Öcalant a lépés megtételére.

Vizsgált időszakunkat, azaz a 2015-ös évet követően a kurd kérdés gyors megoldása elé újabb akadályok gödrültek. Ezek közül az egyik a kurd kisebbség a török közéletben való politikai képviseletének kérdése. A 2012. október 15-én alapított Népek Demokratikus Pártja (HDP) helyzete több szempontból is figyelemre méltó. A szervezetet elsősorban kurdbarát pártként szokás jellemezni, de politikai programjában jól megfigyelhető egyrészt a klasszikus nyugati liberális elem, másrészt pedig a kurdokon kívül egyéb etnikai, vallási, szexuális stb. kisebbségek érdekeinek védelme is. Ez utóbbi miatt a HDP az elmúlt évek választásain a kurdokon túl a nagyvárosi liberális polgárság szavazataira is számíthatott, így például a legutóbbi esetben, 2018. júniusában Isztambul leginkább polgárosodott lakónegyedeiben mintegy $15 \%$-nyi voksot gyüjtött be. Az elnökjelöltekre és a pártlistákra leadott szavazatok összevetése azt is mutatja, hogy egyes baloldali szavazók körében jól működik egy átszavazási mechanizmus, amiből a HDP jól profitál. Ebből következően is a HDP a a 2018. június 24-én megrendezett parlamenti választásokon a rendkívül magas, 10\%-os bejutási küszöböt átlépte és 80 képviselőt küldhet a TBMM-be. Teheti ezt úgy, hogy a párt egyik vezetője, Selahattin Demirtaş és számos más politikus is börtönben ül, és minimális lehetőséget kaptak csupán az állami médiában arra, hogy önmagukat népszerüsíthessék.

Demirtaşt és társait a terrorizmus támogatásával vádolják. Tény, hogy a török közvélemény nagy részében erősen él az a feltételezés, hogy a HDP összejátszik a PKK-val, és hogy az elmúlt 
három évben felélénkült a PKK aktivitása, amire a török kormány is erőteljesebb válaszcsapásokkal felel. A PKK és a kormánycsapatok közötti harcok nem csupán egyre élénkebbek lettek, hanem több esetben már nem is a hegyekben zajlottak, hanem sürün lakott vidékeken, a délkelet-törökországi nagyvárosok történelmi óvárosaiban. Úgy is fogalmazhatunk, hogy a PKK fegyveresei lejöttek a hegyekből, de nem annak érdekében, hogy letegyék a fegyvert, hanem azért, hogy gerilla hadmüveleteiket a síkvidékekre is kiterjesszék. Ugyanakkor több esetben az ellenkező irányú offenzívákra is érdemes felfigyelni, hiszen egyre többször a török fegyveres erök támadják a PKK struktúráit a térségben. A 2015. szeptember 27. és november 5. közötti hadművelet során a török hadsereg Hakkari tartományban számolta fel a szervezet állásait és végzett mintegy 120 fegyveressel. Hasonló, a PKK külföldi hátországát célzó beavatkozásokat Törökország a szomszédos Irakban és Szíriában is folytat. Ezzel bár erősíti a török polgárok biztonságérzetét, súlyosan beavatkozik az arab államok polgárháborúiba.

Bár a 2010-es évek első felében beindult egy egyeztetés az AK Parti és a PKK, a török kormány és a kurd felkelők között, azzal hogy a HDP-t nem sikerült leszorítani a török politikai porondról. Sőt ellenkezőleg, az erőteljes állami nyomás ellenére tért nyert, illetve azzal, hogy a fegyvernyugvás helyett a fegyveres konfliktust kiéleződése figyelhető meg, egy történelmi jelentőségű békekezdeményezést temetett maga alá a két fél makacssága és az, hogy a békés helyett az erőszakos megoldásokat keresték. Úgy tünik, hogy addig nem várható valós megoldás, amíg a török politikai elit nem rajzol fel a kurd kisebbség elé egy olyan jövőképet, mely precízen meghatározza az ő jogaikat és kötelességeiket a harcok lezárulta utáni időkre. Kritikus elemzők szerint a motiváció hiányzik, a kurdok számára azt kellene világossá tenni, hogy miért is éri meg nekik letenni a fegyvert. (HAKYEMEZ, 2017, 7)

2.6.2.6. A kurd kérdés külpolitikai vetülete

Ha megbízhatónak tekintjük Hassanpour és Mojab már hivatkozott írását, akkor azt mondhatjuk, hogy a kurdok mintegy fele Törökországban él, a fennmaradó másik fél pedig főleg a szomszédos országokban, illetve nyugati emigrációban. Ez azt jelenti, hogy a kurd kérdés, sőt, a térség stabilitása nem megoldható úgy, hogy a török vezetés csupán a hazai kurdsággal egyezik ki, de nem keresi a kapcsolatot a szíriai, az iraki és az iráni kurdokkal.

Törökországon kívül Irakban él a legnagyobb kurd közösség, ahol széleskörü autonómiával is rendelkeznek. Szaddam Huszein megdöntése után ez az északi, olajban gazdag régió fokozatosan Törökország stratégiai partnerévé lépett elö. A két entitás közötti együttműködés 
legfontosabb állomása a 2013. november 16-ai találkozó volt a délkelet-törökországi Diyarbakırban. Ez volt az az emlékezetes esemény, ahol Recep Tayyip Erdoğan, az akkori miniszterelnök először használta a Kurdisztán szót a modern török államférfiak közül. Az éljenző tömeg előtt beszélő kormányfő oldalán ott állt Maszúd Bárzáni, az észak-iraki kurd vezető és Sivan Perwer híres kurd hazafias énekes, aki hosszú ideig külföldön élt, mert üldözték politikai nézetei miatt. A történelmi jelentőségü közeledés gazdasági értelemben is sok hasznot hoz mindkét félnek. Törökország az észak-iraki olaj tranzitálásával komoly bevételekhez juthat, miközben több marad a kurdok lakta határmenti régiók fejlesztésére is.

Erdoğan és Bárzáni nevezetes találkozójának nem minden kurd tudott maradéktalanul örülni. Nem szabad szem elöl téveszteni, hogy az egy országban élő kurdok között is vannak ideológiai-politikai jellegü különbségek, illetve sok esetben a különböző országokban élő kurdok eltérő érdekeket képviselnek. Szakértők elsősorban a törökországi kurd formációkat és a szíriai kurd vezetést sorolják a vesztesek közé. A 2014 végén hivatalosan is bejegyzett, törökországi székhelyü Kurdisztáni Függetlenségi Párt például megütközéssel vette tudomásul, hogy Törökország nem kész elismerni az észak-szíriai kurdok autonómiatörekvéseit, mikor az észak-irakiakkal kiegyezett. Miért ez a kettősség a török külpolitikában? Azért, mert a kurdok által Rojavának nevezett észak-szíriai térségben a PKK-hoz közel álló Demokratikus Uniópárt (PYD) a vezető politikai erő. Amíg pedig Törökország nem képes a PKK-val teljesen megbékélni, nincs esély arra, hogy a PYD-vel megtörténjen a közeledés. Hasonló nehézség áll fenn az iráni kurdok ügyében is.

A szíriai kurdokkal való viszony alakulását döntő módon befolyásolták a közelmúlt harci cselekményei is. Mint ismeretes a török határon fekvő Kobanit (arabul: Ain-al-Arab) hónapokon keresztül ostromolta a szélsőséges terrorszervezet, az Iszlám Állam (ISIS). A kobani ütközet több hónapig tartott és végül a kurd erök győzelmével zárult. Ehhez Törökország is hozzájárult azzal, hogy végül megnyitotta a két ország közötti határt, és ezzel számos törökországi kurd átlépve azt, bekapcsolódhatott a küzdelembe.

A kobani ütközetet követően Törökország sokkal aktívabban kezdett el részt venni a szíriai polgárháborúban, meghirdette az Eufráteszi pajzs és az Olajág elnevezésű hadmületeket, melyek során jelentős területeket vont fegyveres ellenőrzés alá azzal a céllal, hogy onnan kiszorítsa azokat az erőket, köztük a szíriai kurd felkelőket is, amelyeket Ankara terrorszervezetként tart számon. A fő célpontok az Iszlám Állam (ISIS) és a szíriai kurd Demokratikus Egyesülés Pártjához köthető Kurd Népvédelmi Erök (YPG) lettek.

A két fent említett szíriai katonai akció közül az Olajág hadművelet irányult a török kormány meggyőződése szerint a PKK-val együttmüködő kurd lázadók ellen. Ez a beavatkozás 
2018. január 20-án indult meg és még a disszertáció írása napján is tart. A török fegyveres erők célja az, hogy saját és a velük szövetséges szíriai csapatok felügyelete alatt tudja az Aleppó tartományhoz tartozó afrini járást és az Azez járásban fekvő Tel Rifát nevü települést, melyek 2017-ig a YPG fontos erősségeinek számítottak, és ahonnan feltételezések szerint több támadást is indítottak törökországi és török katonai célpontok ellen. A hadművelet során március közepén következett be a fordulat, mikoris a török és a velük szövetséges erök elfoglalták Afrint és több más jelentős mezővárost, így Radzsót és Dzsindereszt. Ugyan a törökök ellenőrzést gyakorolnak mintegy $2.000 \mathrm{~km}^{2}$ felett, még június utolsó napjaiban sem mondható el, hogy megszállták volna a járás egészét, azaz a végső célt máig nem érték el. Bár a nemzetközi közvéleményt megosztotta az Olajág hadmüvelet, a legfőbb világhatalmi tényezők nem avatkoztak abba bele, hiszen - mivel Törökország nem használja a fegyveres támadás kifejezést- úgy tekintenek arra, mint Törökország jogos önvédelmi mechanizmusára egy terrorista fenyegetéssel szemben. (PETERS, 2018, 1) Történik mindez paradox módon úgy, hogy a Nyugat többféle módon is segítette 2017-ig a YPG-t.

\subsubsection{Egyéb etnikai kisebbségek}

A török belpolitika egyik meghatározó kérdése a fentebb tárgyalt kurdok helyzete. Bár a többi kisebbség lélekszámát tekintve is kevésbé lényeges politikai tényező, érdemes röviden velük is foglalkozni, hogy teljes legyen a törökországi etnikai mozaik.

Törökország lakóinak többsége az anatóliai törökök közé sorolható, - becsült arányuk eléri a 81,3\%-ot - rajtuk kívül még a türk nyelv- és népcsaládhoz tartoznak az azeriek, a tatárok, a karacsájok, a karakalpakok, a kazahok, az üzbégek és az ujgurok. Közülük a becsült másfél milliós lélekszámmal az azeriek lehetnek a legtöbben. A türkök után a legfontosabb népességelem az indoeurópai család indoiráni ágába sorolható a legnépesebb kisebbség, a fent már részletesen is bemutatott kurdok (akik számát Sirkeci már idézett munkája szerint 6 és 12,6\% közé tehetjük), valamint a zazák. Az indoeurópai népek közül európai eredetüek a bosnyákok, az albánok, a görögök és az örmények. A bosnyákok és az albánok a balkáni háborúk következtében menekültek nagyobb számban a mai Törökország területére. A sémi néptöredékek közé soroljuk a Hatay és Şanlıurfa környékén tömbben élő arabokat, a Mardin környéki asszírokat és a zsidó közösség tagjait. A kaukázusi népekkel rokonok a grúzok, a lázok, a cserkeszek és a csecsenek. Érdekességképpen megjegyezhetjük, hogy néhány száz török állampolgár magyar felmenőkkel is büszkélkedhet, többek között azok a Mardin 
megyéhez tartozó Nusaybin járásbéli lakosok, akiknek az ősei az 1848-49-es forradalom és szabadságharc után telepedtek le a mai török-szír határvidéken.

Török népek: a ma anatóliai törökökként emlegetetteken kívül jelentős számban élnek közép-ázsiai eredetü törökök is Törökországban. Közülük a mai Törökország területét először valószínüleg a türkmének érték el, akik körében ekkor két csoportot különböztettek meg: a manavokat, azaz a letelepedetteket és a yörüköket, vagyis a nomád életmódot követőket. Ez a két csoport mára jól kitapintható etnikai kategóriává lényegült át, és együtt a lakosság mintegy 1\%-át adják. A türkmének e két csoportján túl a mai Türkmenisztán államalkotó nemzetét jelentő türkmének is megtalálhatóak Törökországban. A becslések szerint minden négyszázadik török állampolgár közülük kerül ki.

Zazák: a zaza nép Kelet-Anatóliában él, de Iránból származik. Számukat egy és kétmillió fő közé becsülik. A zaza önazonosság tudata a 20. század elején kezdett kifejlődni, ekkor kezdte az iszlám vallási irodalmat Ahmed el-Hászi zaza nyelvre lefordítani, ekkor született meg a nyelv írásbeli változata is. A népcsoport a politika elit érdeklődési körébe a köztársaság első éveiben került köszönhetően annak, hogy Atatürk jó személyes kapcsolatokat ápolt Diyap Yıldırımmel, a zaza nép parlamenti képviselöjével. Mint azt már írtuk, a török nacionalizmus legfőbb ideológusa, Ziya Gökalp is félig zaza származású volt.

Bosnyákok: a bosnyákok török földre áramlása úgy kezdődött, hogy az Osztrák-Magyar Monarchia megszállta az addig az Oszmán Birodalomhoz tartozó Boszniát 1878-ban. Az utolsó nagy bevándorlási hullám akkor zajlott, amikor a ma Szandzsáknak nevezett Novi Pazari szandzsákot (megyét) is elvesztették az oszmánok, és azt felosztották Szerbia és Montenegró között. A menekültek szétszóródtak az országban, megtalálhatjuk őket İzmir, Eskişehir, Bursa, Yenişehir, Ankara, İstanbul, Karamürsel, İnegöl, Biga, Afyonkarahisar, İzmit és Adapazarı városaiban, Isztambul egyik legnépesebb európai külvárosát sem véletlenül hívják Yeni Bosnának, azaz Új Boszniának.

Albánok: az albánok első csoportja a 15. században érkezett Anatóliába, hogy ott katonai és irodalmi tanulmányokat folytasson. Az oszmán időkben az albánokat úgy ismerték, hogy kiváló működtetői a birodalmi közigazgatásnak. Többek között a híres egyiptomi alkirály, Mohamed Ali és az utolsó budai pasa, Abdurrahman Abdi Arnavut is albán származású volt. Egyes becslések szerint az oszmán vezírek és felső vezetők mintegy $60 \%$-a volt albán eredetű. Az albánok arra is büszkék, hogy közülük került ki a török nemzeti himnusz, az İstiklal Marş1 szerzője, Mehmet Akif Ersoy is. A kisebbségi csoport saját, 1965-ös felmérése szerint több mint félmillió albán élt Törökországban, föleg Samsun, Tokat, Yozgat, İstanbul, Bursa, İzmir, Ankara és Sakarya városaiban. 
Arabok: a törökországi arabok számát a becslések 1,8-2,6 millió fő közé teszik. Nagy részük a török-szír határ mentén él, de attól kicsit északabbra, Adana megyében is találkozhatunk arabokkal. Az arabok őshonos kisebbségnek tekinthetőek: a mai török-szír határ nagyjából megegyezik a török-arab nyelvi határral úgy, hogy annak mindkét oldalán él a másik nép kisebbsége is. A zömmel a 19-20. században a Balkánról bevándorolt népekkel szemben az arabok a vidéki területeken is nagy számban élnek.

Kaukázusi népek: Törökország északkeleti részét hosszú ideig Lazisztánnak hívták utalva arra, hogy lakói közül sokan a kaukázusi eredetü láz néphez tartoztak. A lázokon kívül sok más kis hegyi nép (grúzok, az iszlám hitre tért örményeknek tartott hemsinek stb.) él főleg az említett terület falvaiban, hiszen a városok török többségüek. Ennek az oka pedig az, hogy az eredendően keresztény lázok nagy része áttért az iszlámra és eltörökösödött. Azok, akik keresztények maradtak, elgörögösödtek. A kaukázusi származásúak száma a 19. század közepén nőtt meg jelentősen, amikor is az orosz-török háború elől több százezren menekültek török földre. Hasonló népvándorlás volt megfigyelhető Sztálin rémuralma idején is.

Örmények és görögök: a legnépesebb nem-muszlim etnikai csoport Törökországban az örményeké. Számukat 40-70 ezer között becsülik, nagy többségük Isztambulban él. A legnagyobb török városban 36 örmény ortodox templom müködik. Isztambulon kívül Hatay városában él a legtöbb örmény, ott három templomot müködtetnek. Az örmények száma az Oszmán Birodalomban nagyjából 2,5 millió lehetett, ugyanakkor az I. világháború során zajló török-örmény polgárháború és az örmények kitelepítése folytán az anatóliai örménység létszáma minimálisra csökkent. Az egyes országok által népirtásnak megbélyegzett sajnálatos események során nagyon sok török és örmény polgári személy vesztette életét, ám a török álláspont szerint nem beszélhetünk genocídiumról, hiszen nem létezett központi politikai szándék az örmények megsemmisítésére.

A Bizánci Birodalom területét fokozatosan meghódító oszmánok számos görög alattvalóra is szert tettek. A görögök jelentős része városokban élt, és kereskedelemmel foglalkozott. Legnagyobb számban İzmirben laktak, ahonnan - mint az ország más részeiről is - az I. világháborút követő török-görög lakosságcsere keretei között lettek kitelepítve. Ma már csupán 3-4 ezer görög élhet Törökországban, föleg az Isztambulhoz tartozó Hercegnő-szigeteken.

\subsubsection{Vallási kisebbségek}

Az ország vallási megoszlásáról sokkal pontosabb képet kaphatunk, mint az etnikairól, hiszen az arra vonatkozó adat szerepel a török állampolgárok személyi igazolványában. A 2013-as, 
vallásszabadságról szóló jelentés szerint Törökország lakóinak döntő többsége muszlim, ezen belül szunnita. Mintegy félmilliós síita muszlim kisebbség is él a szunniták között. Ök etnikai szempontból zömmel azeri származásúak. A többségében örmény, asszír és bolgár származású keresztények számát 167.500-ra teszik, ez az összlakosság 0,2\%-a. A törökországi zsidók 21 ezren lehetnek.

Zsidók: izraeliták már a hellenizmus korában, leghamarabb az ie. 4. században megjelentek Anatóliában. A bizánci időkben romaniotnak nevezett zsidók főleg az égei-tengeri partvidéken és a mai Ankara környékén éltek. Mint látjuk, zsidók már évezredek óta léteztek a mai Törökország területén, de nagy számban csak azután telepedtek le ott, hogy az 1492-ben egységesülö Spanyolország elüldözte a szefárd zsidókat, akiket II. Bejazid szultán fogadott be, és a balkáni nagyvárosokban (Edirne, Tesszaloniki, Szkopje és Szarajevó) lelhettek új otthonra. 1925-ben hivatalosan is elismert kisebbségi vallási szervezet lett a Török Zsidó Közösség. Bár az 1930-as években Törökországban is voltak antiszemita jelenségek, és ennek hatására a vidéki zsidóság Isztambulba áramlott, a II. világháborúban semleges Törökország számos török és nem-török származású zsidót fogadott be, és mentett meg a nácik kezei közül.

Az ősi fővárosban, Edirnében, ahol már csak egy zsidó vallású személy él, a közelmúltban újították fel Törökország legnagyobb izraelita imaházát, az ún. Nagy Szent Zsinagógát. A zsidók fontos müemlékének megújulásában nagy szerepe volt az $\mathrm{AK}$ Parti toleráns politikájának is. A negyvenhat év elteltével, 2015 márciusában újra felszentelt hely megnyitóján Bülent Arınç miniszterelnök-helyettes is megjelent. (Érdekességképpen megjegyezhetjük, hogy a világban - nagyobb részben a Baltikumban - mintegy 50 ezer karaj zsidó él, akik vérségileg törökök, ám izraelita vallásúak.)

Keresztények: az Erdoğan-korszak a vallási kisebbségek tekintetében is megújulást jelent, hiszen több ősi templomot felújítottak, így restaurálták Miklós püspök templomát az Antalyához közel található Demrében. A keresztények és az örmények felé tett kormányzati gesztusnak tekinthetjük azt is, hogy a nevezetes Akdamar-szigeti templom - kilenc másik müemlékkel együtt - a török politikai vezetés javaslatára az UNESCO világörökségi listájára is felkerült.

A 2015. január 2-án a vallási kisebbségi vezetőkkel a Dolmabahçe-palotában találkozó Ahmet Davutoğlu akkori miniszterelnök - többek között - azt jelentette be, hogy 90 év után először adnak engedélyt arra, hogy új templom épülhessen az országban. Ezzel a lehetőséggel az asszír keresztények élhetnek, akik Isztambul egyik elegáns európai villanegyedében, Yeşilköyben építhetik fel imaházukat egy örmény, egy görög és egy katolikus templom közelében. Szintén nyilvánosságra került az a terv is, hogy a dél-törökországi Iskenderunban 
egy, az atatürki időkben mozivá alakított örmény templomot is felújítva adnak vissza eredeti tulajdonosaiknak.

Bár az AK Parti-kormány idején születtek gesztusok a keresztények felé, három sérelmükre elkövetett gyilkosság is borzolta a kedélyeket. 2006 februárjában a Fekete-tenger melletti Trabzonban megölték Andrea Santorót, egy fiatal, olasz származású katolikus papot. A jótevőjét meggyilkoló fiatalembert később 18 éves börtönbüntetésre ítélték. Ez a gyilkosság csak az első volt a sorban, és kevesebb figyelmet kapott, mint mikor 2007. január 19-én Hrant Dinket, az örmények Agos címü lapjának főszerkesztőjét lőtték le Isztambulban a nyílt utcán azután, hogy a lapban már évek óta cikkeztek arról, hogy az egyik isztambuli repülőtérnek is nevet adó híres pilótanő, az Atatürk egyik „szellemi gyermekének” számító Sabiha Gökçen valójában örmény származású volt. Dink a török örmény közösség egyik legprominensebb hangja volt, így emiatt gyakran vált a nacionalista harag és különböző jogi eljárások célpontjává. Több alkalommal is pert indítottak ellene. A fegyveres támadás mögött szélsőjobboldali aktivisták álltak, a gyilkosságot Recep Tayyip Erdoğan akkori miniszterelnökkel az élen a teljes politikai elit elítélte, hatalmas tömeg tüntetett az újság székháza előtt a „mi mind Hrant vagyunk, mi mind örmények vagyunk” szlogent hangoztatva. Alig három hónappal a Dink-gyilkosság után az örmény újságíró szülővárosában, Malatyában törtek rá a Biblia-kiadással foglalkozó Zirve kiadó központjára, ahol két török és egy német állampolgár torkát vágták el. A kormány ezt a támadást is élesen elítélte. Bár az eset bírósági kivizsgálása még tart, azt már összefüggésbe hozták a már tárgyalt Ergenekon-féle összeesküvéssel.

Alevik: a vallási kisebbségek közé sorolhatjuk az iszlámon belüli kisebbségi irányzatok híveinek csoportjait is. Törökországban közülük a legnépesebb az alevi közösség, akik az iszlám történetének negyedik kalifáját, Ali ibn abi Tálibot tekintik kiemelkedően fontos példaképnek. Az alevik bár a Balkánon és Nyugat-Törökországban is megtalálhatóak, de legnagyobb csoportjaik Kelet-Anatóliában, különösképpen pedig Tunceli térségében élnek. A köztársasági időszak elején a törvény erejével zárták be az imahelyeiket, az ún. dzsemeviket (közösségi házak). Ma ezek újra megnyílhatnak, alevi kulturális egyesületek alakulnak, és az iskolai hittanoktatásba is bekerülnek tanításaik.

A vallási kisebbségek térnyerését mutatta a politikában, hogy a 2015-ös választásokon minden politikai párt fontosnak tartotta, hogy a vallási kisebbségek közül is állítson jelölteket, sokakat közülük esélyesnek is tart a sajtó arra, hogy képviselök legyenek. A kormánypárt az örmények egyik emblematikus figuráját, a társadalomtudóst és a Yeni Şafak címü napilap szerkesztőjét, Markar Esayant indította, de a jelölési procedúra során még egy bodrumi 
keresztény lelkipásztor, Engin Duran neve is felmerült. A kötelező hitoktatás ellen is kampányoló, ellenzéki Népek Demokrata Pártja (HDP) nem csupán örmény, de asszír keresztény és jezidi jelöltet is indított. Isztambulban a legfőbb ellenzéki pártnak, a Köztársasági Néppártnak (CHP) is volt örmény jelöltje. Az alábbi összegzés a kurdokkal kapcsolatban hangzott el ugyan, de az összes kisebbségre igaznak tekinthető. „Minden elődje közül Erdoğan bizonyult a legmegértőbbnek a délkelet-törökországi kurdok problémái iránt” - írja Flesch István 2007-ben, azaz még a kurd nyitást megelőző években. (FLESCH, 2007, 141) Ez azt jelenti, hogy a megközelítésbeli különbség már az AK Parti kormányzásának korai szakaszában is jól érzékelhető volt. Az AK Parti új nemzetkoncepciót mutatott fel, aminek a lényege az, hogy az ország képes nagy dolgokat véghezvinni, de annak előfeltétele az egység. A kurdok jogainak biztosítása és életminőségük javítása egy nagyobb cél, a Tek milletkoncepciója megvalósításának része. A Tek millet olyan értelemben egy nemzet, hogy egységes a céljaiban, de tiszteletet tanúsít a sokszínű kisebbségek felé.

2.7. Az AK Parti megítélésének romlása, látványos politikai feszültségek megjelenése: a Gezi park

Isztambulnak van egy zöld területe, ami sem nem nagyobb, sem nem szebb, mint a város számos másik parkja, mégis szinte mindenki hallott már róla. Ez a Gezi park, azaz a Sétatér. A Gezi park a Boszporusz-parti metropolisz európai felén, annak üzleti negyedében, a szimbolikus, forgalmas tér, a Taksim közvetlen közelében fekszik. Hírneve azonban nem abból fakad, hogy központi elhelyezkedésü, illetve népszerü a környék luxusszállóiban időző üzletemberek körében, hanem abból, hogy a 2013-as törökországi elégedetlenségi hullám helyszíne és egyszerre jelképe is. Az akkor már több, mint tíz éve kormányzó, egymás után három választást is megnyerő Igazságosság és Fejlődés Pártja ezen eseménysor kapcsán szembesülhetett azzal, hogy a társadalom egyes szegmensei nem csupán szavukat emelik fel az általuk autoriternek tartott kormány egyes döntéseivel szemben, hanem aktív ellenállásba fognak. A Gezi park kivágásra ítélt fái miatt kirobbant tiltakozás eleinte csupán környezetvédők maroknyi csoportját érintette, akikhez - a rendfenntartó szervek erőszakos fellépése és a kormány kezdetben nem túl szerencsés kommunikációja miatt - kormány- és rendszerkritikus csoportok tucatjai csatlakoztak szerte Törökországban. 


\subsubsection{A Gezi park története}

A Gezi park vagy magyarul Sétatér Isztambul egyik viszonylag fiatal urbanisztikai eleme, hiszen csupán 1940-ben jött létre egy lerombolt egykori katonai létesítmény, az 1780-as évektől kezdve épített Taksim Kışlası vagy Halil Paşa Topçu Kışlası néven is ismert laktanya helyén. Ez az épület a 19. században egyszer leégett, és Abdulmedzsid szultánsága idején orosz és indiai stíluselemek felhasználásával építették újjá. A késő oszmán kor egyik legimpozánsabb létesítménye ekkor már háromemeletes volt, két monumentális kapuval is kibővült. A 20. század első felében megváltozott a funkciója, egy ideig itt müködött a kereskedelmi és iparkamara, majd fokozatosan labdarúgó pályává alakították át. A köztársaság kikiáltása után Taksim stadion néven kezdték hívni, itt rendezték meg a török nemzeti tizenegy első hivatalos mérkőzését is.

Lütfi Kurdar Isztambul kormányzója és polgármestere 1940-ben arról határozott, hogy a városból modern világvárost farag. A kor neves francia építészét, Henri Prostot bízta meg a tervek elkészítésével. Prost azt javasolta a városvezetőnek, hogy az egykori laktanyát rombolják le, és a helyén hozzanak létre egy többcélú szórakoztató centrumot (Aydemir, 2008). Ez utóbbira azonban nem volt meg az anyagi fedezet a települési költségvetésben, így lett végül a Halil Paşa Topçu Kışlası helyén közpark, ahová egy közeli örmény temető, a Surp Hagop sírköveiből készültek márvány lépcsők és padok. Ez is jól mutatja, hogy a köztársaság egypárti szakaszában nem voltak tekintettel sem a nemzetiségi és vallási kisebbségek, sem a szultánság és épített öröksége iránt nosztalgikus konzervatív törökök érzékenységére. 1944-ben elkészült az adott időszak köztársasági elnökének, İsmet İnönünek a lovasszobra, amit szintén itt terveztek elhelyezni. Ugyan a mü évekig egy raktárban porosodott, és végül egy másik parkba került, mégis ezt a területet kezdte a nép İnönü sétatereként emlegetni. A park területe az ezt követő években folyton csökkent, hiszen több luxusszálloda is épült a helyén, az 1991-92-es felújítás során pedig egy hatalmas díszkutat építettek a közepébe. A megállás nélkül visszahúzódó zöld terület ellenére a Gezi park Isztambul egyik legkedveltebb pihenő övezte lett, és hozzánőtt a városlakók szívéhez.

\subsubsection{A Gezi park és környezetének átépítése}

A látványos gazdasági fejlődés lehetővé tette, hogy a helyi önkormányzatok is komoly városrendezési projektekben gondolkozzanak. Isztambul még mintegy két évtizede is átmenetet 
képzett Kelet és Nyugat között, elmondható volt róla, hogy koszos és zürös nagyváros, ahol a közlekedés kaotikus, nincsenek számottevő építkezések, és általában a pangás jeleit mutatja. Recep Tayyip Erdoğan politikai tehetségét itt bontakoztathatta ki elöször, mint föpolgármester, az első fejlesztések éppen az ő nevéhez köthetőek, Isztambul az ő vezetésével kezdett világvárossá fejlődni. Isztambul Város Közgyülése 2011 szeptemberében fogadta el annak a nagyszabású tervnek a körvonalait, mely a „Taksim tér gyalogos övezetté való átalakítása” címet viselte. Az önkormányzati képviselők szavazategységével elfogadott javaslat szerint egyesítik a Taksim teret és a Gezi parkot, közvetlen gyalogos összeköttetést teremtenek a környező utcákkal, eltüntetik a tér közepét csúfító metrólejárókat és a zürzavaros buszállomást úgy, hogy a tömegközlekedés egésze a föld alá kerül, valamint a metróvonalak továbbépítésével biztosítják a város többi részének könnyü elérését kötöttpályás közlekedési eszközök segítségével. Mint látjuk, 2011-ben a politikusok többsége támogatta a tervet, a civil társadalom nem emelte fel a szavát az ellen, a tervekről beszámoló török sajtóorgánumok pedig azt hangsúlyozták, hogy a téren $98.000 \mathrm{~m}^{2}$ alapterületủ gyalogos zóna jön létre. A Taksim téri fejlesztések teljes egészében beilleszkedtek abba a dinamikus területrendezési történetbe, ami még Recep Tayyip Erdoğan polgármestersége idején indult, és Kadir Topbaş vezetése alatt is folytatódott, és amiről valószínűleg nem szerzett volna tudomást a világ, ha az azok elleni későbbi tiltakozást nem használják ki egyes politikai szereplők.

Az első tüntetésre a leendő építkezések ellen 2012 júniusában került sor, amikor is az önkormányzat bejelentette, hogy megszerezte a szükséges szakhatósági engedélyeket, és 240 napon belül megkezdődik a terület gyalogos zónává alakítása. A „Taksim téri szolidaritás” elnevezésű rendezvényt a környék lakóit és vállalkozóit tömörítő egyesületek szervezték, azaz a kezdetek kezdetén politikamentes volt a protestálás, a tüntetők jelszava is az volt, hogy ,a Taksim nem a kormányoké, hanem a mi közös terünk”. A békés tiltakozás során egy mérnökszervezet képviselője átadta a környéken élőknek a tér jelképes telekkönyvi kivonatát. A Taksim téri szolidaritás egy szük értelmiségi kör volt. A környéken lakó, általában felső középosztálybeli elégedetlen polgárok zöme távol tartotta magát a politikától. Aktivitásuk a lakókörnyezetük radikális átalakulása mellett azzal magyarázható, hogy az AK Parti intézkedéseinek köszönhetően az ő anyagi helyzetük is megerősödött, a stabil polgári lét pedig lehetővé teszi a civil kurázsi megélését.

2012. október 31-én megkezdődött a Taksim tér gyalogos övezetté alakításának első fázisa. A közbeszerzési eljáráson a Kalyon építőipari vállalatot hirdették ki győztesként. Lerombolták a park oldalában húzódó igénytelen bódésort, és tervbe vették a sokak, főleg a kormánypárt támogatói által olyannyira kedvelt Halil Paşa Topçu Kışlası újbóli megépítését azzal a céllal, 
hogy abban egy új funkciót erősítsenek fel: a kereskedelmet, hiszen a város üzleti negyedének szomszédságában van a Gezi park.

\subsubsection{Tömeges fakivágással járó projektek Törökországban}

Vajon a Gezi parki volt az első nagyszámú fakivágással járó projekt Törökországban? Ha röviden szeretnénk válaszolni erre a kérdésre, akkor azt kell, hogy mondjuk, hogy nem. Egészen a közelmúltig a törökországi beruházások során a környezetvédelmi megfontolások nem tartoztak a leginkább számottevő tényezők közé. A Gezi parki tiltakozás kapcsán is több más hasonló projekt került újfent az érdeklődés homlokterébe. Ilyen volt az a „fairtás”, ami a Koç Egyetem építése során volt tapasztalható, melynek során 1997-ben 80.000 fát vágatott ki egy baloldalhoz kötődő üzletember, vagy az 1997-es eset, mikor jobboldali vállalkozók ingatlanfejlesztésének útjában állt több ezer fa

Sokan felteszik a kérdést, hogy ezek, a Gezi parkinál sokkal jelentősebb erdőirtások miért nem érték el a török közvélemény ingerküszöbét, a Gezi parki fák pedig miért váltak egy országos elégedetlenségi hullám kiváltóivá. Az egyik válasz az, hogy a török média nem foglalkozott kellő mélységben ezekkel a témákkal, a Koç-ügy idején az internet még nem volt elterjedt, a törökök többsége még nem használta a közösségi oldalakat. A másik, hogy a török civil társadalom és a zöld mozgalmak csupán az utolsó néhány évben erősödtek meg annyira, hogy felszínre tudjanak hozni ilyen, eddig a közvéleménytől gondosan elzárt témákat. Az, hogy a fakivágások egyre inkább rossz érzéssel töltik el a törököket azzal is összefüggésben van, hogy a Nyugat hatása is egyre egyértelmübb. Nyugaton már évtizedek óta fontos eleme a politikai köztudatnak és gondolkodásnak a fenntartható fejlődés. Mára eljutottak a törökök is oda, hogy nem elég átalakítani és kizsákmányolni a környezetünket, azzal úgy kell bánnunk, hogy az még a jövő generációkat is szolgálhassa.

\subsubsection{A török civil és zöld mozgalmak}

Törökországban több évszázadra visszamenő hagyománya van az alapítványoknak. Már az oszmán időkben is a legtöbb vallási létesítmény, fürdő, könyvtár és ingyenkonyha alapítványi formában müködött. A köztársaság kezdeti, egypárti időszakában számos régi alapítvány kénytelen volt megszüntetni vagy szüneteltetni müködését, ezek és általában az alapítványok az elmúlt harminc évben reneszánszukat élték. Más civil társadalmi szervezetek - mint az egyesületek, a szakszervezetek és a szakmai szervezetek - a 20. században jelentek meg, és 
terjedtek el. A civil szféra egyértelmű térnyerése az AK Parti időszakára tehető, a 2000-es években születtek meg azok a modern, demokratikus törvények is, melyek ezek müködését szabályozzák: az egyesületek a 2004-ben elfogadott, és a török hivatalos közlönyben, a Resmi Gazetében 2004. november 23-án megjelent, 5253-as számú Egyesületi törvény, míg az alapítványok a 2008-ban megszavazott, és a közlönyben 2008. február 20-án publikált 5737-es Alapítványi törvény hatálya alá esnek.

Törökországban az első környezetvédő szervezetek az 1950-es években jelentek meg. Ezek eleinte csupán egy-egy helyi problémával foglalkoztak, mint az isztambuli Aranyszarv-öböl vízszennyezettségével, majd egyes jelenségek árnyoldalát igyekeztek kivizsgálni, így voltak olyanok, akik a népességnövekedés vagy éppen az iparosodás okozta károkkal törődtek. Eleinte elszigetelt jelenségnek számítottak, és távol tartották magukat a politikától ezek az egyesületek, amit egyébként tiltott is számukra a korabeli alkotmány. Az első zöld formációk, amelyek jelentősebb társadalmi támogatottságot tudhattak maguk mögött: a Zöld Béke Környezetvédő Egyesület (Yeşil Barış Çevre Derneği), valamint a Törökországi Légszennyezés Ellen Küzdő Egyesület (Türkiye Hava Kirliliğiyle Savaş Derneği) voltak. Ezek az ország történetében először a politikai köztudatba is beemelték a zöld tematikát azzal, hogy 1987-ben létrehozták a Zöldek Pártját. (AYGÜN-SAKACI, 2015, 143) Bár az ökológiai gondolat világméretü terjedésének időszaka az 1980-as évek, Törökországban ekkor még csupán a civil szervezetek 2\%-a dolgozott ezen a területen. (ADEM, 2005, 72-73) A 2000-es évekre, azaz az AK Parti kormányra jutása után megkétszereződött a zöld szervezetek száma. Ezek jellemző módon már egy globális zöld gondolkodás irányába mozdultak el, a környezetvédelmet sokszor politikai alapvetésnek tekintették, körükben megjelent a radikális zöld gondolat is, ugyanakkor a radikális cselekvés még nem volt számottevő. A zöld mozgalom kiterebélyesedése nem következhetett volna be az AK Parti demokratikus nyitási politikája nélkül. Paradox módon viszont ez a nyitás az AK Parti helyzetét is megingatta azzal, hogy a demokratizálódás során a kormánnyal szemben kritikus szervezetek is születtek és váltak kimondottan aktívvá.

A legkorábbi olyan tiltakozó mozgalmak, melyek egy-egy környezetkárosítást igyekeztek megakadályozni az 1990-as évek végén, a 2000-es évek elején jöttek világra. Az első ilyen eset a történelmi Pergamonban, a ma Bergamának nevezett járásban történt. A Bergamai Mozgalom kiváltó oka egy aranybánya létesítése volt, ám az abban résztvevő falusiak csakhamar a környezeti normákat figyelmen kívül hagyó neoliberális politikusok ellen is felemelték a hangjukat. A bergamai tiltakozások során a polgári engedetlenség békés formákat öltött. (ÖZEN, 2009) Az első erőszakos jelenetek csupán a Gezi park fái kapcsán kerültek az újságok címlapjaira. 


\subsubsection{Tüntetés a Gezi parkért}

A Gezi parki események azzal vették kezdetüket, hogy 2013. május 27-én a park azon falának öt méteres darabja, amely az Askeri Ocağı utca felé nézett a napközben végzett munkálatok folyományaként, ám már a munkások elvonulása után ledőlt, ezzel öt fa gyökerestől kiszakadt. Ekkor a már említett Taksim Téri Szolidaritás elnevezésű csoport ötven aktivistája jelent meg a parkban, hogy elejét vegyék az építkezésből fakadó további károkozásnak. Másnap reggel a falat tovább bontani szándékozó munkások már egyre több és több tüntetővel találták szembe magukat, sőt megjelent egy országgyülési képviselő is, az általában a kurd kisebbséghez kötődőnek mondott Béke és Demokrácia Pártja (Barış ve Demokrasi Partisi, BDP) tagja, Sırrı Süreyya Önder is, ezzel a tér átalakítása és a környezeti probléma csakhamar politikai színezetet is kapott. Önder a tudósítások szerint azt mondta, hogy „nem hagyjuk kivágni a fákat, nem hagyjuk, hogy a szegény emberektől elvegyék az árnyékot”. Ezzel a mondattal egyértelművé vált, hogy a tiltakozás már nem csak a fákról szól, és nem is kifejezetten a szegényekről, hiszen a közelben van egy másik, a Gezinél is nagyobb park, ahol szintén hüsölhetnek a környék amúgy általában jómódúnak mondható lakói. A nap folyamán később személyesen is támogatásáról biztosította a tüntetőket Gürsel Tekin, az ellenzéki Köztársasági Néppárt (CHP) főtitkára is. A politikusok megjelenése már ezen az első napon azt mutatja, hogy az AK Parti ellenzéke esélyt látott arra, hogy rátelepedjen a tiltakozásokra. Céljuk ekkor még biztosan nem a kormány megdöntése volt, hanem a közvélemény tematizálása. A zöld ügyet olyan új témának tekinthették, amivel az egyre inkább a nyugati eszmék hatása alá kerülő városi rétegek megszólíthatóvá válhatnak.

A Kalyon építőipari vállalat biztonsági emberei többször is megpróbálták a munkagépek útját elálló tömeget szétoszlatni, de sikertelenül. A tiltakozók sátrakat emeltek, másnapra pedig sajtótájékoztatót, koncertet és filmvetítést is meghirdettek. A hirtelen sokféle programot kínáló protestálók láttán felmerülhet az a gondolat, hogy a tüntetés már ekkor elvesztette spontán jellegét, a Taksim Téri Szolidaritás az irányítást a kezébe véve megszervezte az elkövetkező napok eseményeit. A tüntetések civil kezdeményezői megkísérelték a pártoktól visszavenni a kezdeményezést. Ezen a ponton még kétséges volt, hogy az AK Parti demokratikus nyitásának és gazdaságpolitikájának köszönhetően megerősödő civilek vagy a parlamenti ellenzék tud a demonstrációk élére állni.

A falomlást követő második napon már egyértelműen a politikáé lett a főszerep. Május 29én hajnali öt órakor a rendőrség felszámolta a Taksim tériek sátortáborát, a tüntetőket 
kiszorította a parkból és a térről. Ugyanezen a napon mondott beszédet Recep Tayyip Erdoğan a Yavuz Sultan Selim-híd alapköletételén, melyen a Gezi parki eseményekre is utalt, és a következőket hangoztatta a kezdődő elégedetlenségi hullám kapcsán: „azt csinálnak, amit akarnak, döntöttünk, megcsináljuk”, azaz egyértelművé tette, hogy a tiltakozások ellenére az eltervezett építkezés meg fog valósulni. Aztán, amint a miniszterelnök a leendő híd névadása kapcsán már támadások kereszttüzébe került, hiszen a szunnita többség szemében jelentős uralkodónak és az első török származású kalifának számító I. Szelimet az alevi kisebbség azzal vádolja, hogy egy anatóliai felkelés során 40.000 hittestvérüket ölette meg, az ellentmondást nem türő hang csak olaj volt a tüzre. Az ellenzék majd minden szereplöje igyekezett meglovagolni a tüntetések kínálta nem várt lehetőséget: Kemal Kılıçdaroğlu, a CHP vezetője is megjelent a helyszínen és közölte a tüntetőkkel, hogy a CHP valamelyik képviselöje minden egyes nap tiszteletét teszi majd a téren.

A rendőrség eközben egyre erőszakosabban lépett fel a folyamatosan növekvő tömeggel szemben. A rendőri brutalitás a politikusokat sem kímélte: Önder kétszer is megsebesült, a CHP-hez tartozó Sezgin Tanrıkulu pedig elájult a belélegzett paprikagáztól. A rendfenntartók brutalitása megrázta Törökország népét, hiszen az elmúlt évtizedekben sajnos megszokottá vált a hatósági erőszak az országban, de éppen az AK Parti kormányzása volt az az időszak, amikor ez egy kicsit alábbhagyott. Az újfent megjelenő vízágyúk és könnygáz-gránátok meglepték azokat a törököket, akik „elkényelmesedtek” a 2000-es évek gyors gazdasági fejlődése és politikai-társadalmi átalakulása során, azaz nem számítottak arra, hogy a demokratikus nyitás után a hatalom így csap le egy kezdetben békés mozgalomra.

\subsubsection{Országos tiltakozás}

Míg a tiltakozás első estéje még valóban a Gezi park fáiról szólt, a folytatásban inkább a kormányellenes felhang dominált a környezetvédelem helyett, az új tiltakozó mozgalomhoz pedig Törökország-szerte sokan csatlakoztak. Így megmozdulások voltak Ankarában, İzmirben - ahol szintén összecsaptak a tüntetők és a rendfenntartó erők -, Mersinben, Tunceliben, İzmitben, Manisában, Marmarisban, Adanában, de még az ultrakonzervatívnak tartott Konyában is, Zonguldakban pedig a tiltakozók a Bülent Ecevit Egyetem diplomaosztó ünnepségét használták fel elégedetlenségük kifejezésére. A helyi stadionban a mintegy 4.000 frissen végzett diák arra lett figyelmes, hogy a karzaton egy „A Gezi park fellázadt, üdvözlet a Taksim térieknek" feliratú transzparenst feszítettek ki. Az üggyel kapcsolatban a rendőrség öt egyetemistát vett őrizetbe. 
Május 31-én egy isztambuli bíróság arról döntött, hogy visszavonja a vitatott Halil Paşa Topçu Kışlası építési engedélyeit. Azaz az eredeti problémát alapul véve okafogyottá vált a tiltakozás, ám ekkorra már országos méretűvé nőtte ki magát az ellenzéki mozgalom: 48 megyében mintegy 90 tüntetés zajlott június elsején, melyeken közel ezer embert vettek őrizetbe. A zavargások következtében több százan sérültek meg, köztük 15-en súlyosan.

Az egyre feszültebb hangulatot csak fokozták a kormányfő szavai: „Igen, egy dzsámit is felépítünk (a Taksim téren). Ehhez sem a CHP elnökétől, sem az útonállóktól nem kérek engedélyt, hiszen azok, akik ránk szavaztak, erre felhatalmazást adtak nekünk.” Az oszmán időkben zömmel keresztények által lakott Taksim tér környékén máig nincs iszlám imaház, csupán egy lakásból kialakított kis helyiség a mủemlék villamos garázsa mellett, ahol minden egyes ima során százak zsúfolódnak össze. Szükség van tehát mecsetre a környéken, de egyértelmüen látható, hogy Erdoğan ezekkel a szavakkal ekkor még nem a békés megoldás irányába szándékozott mozdulni. Figyelemre méltó az is, hogy ebben a megszólalásában a tüntetőkkel kapcsolatban az útonálló, fosztogató, martalóc értelmü „çapulcu” kifejezést használta, amivel megsértette a téren tiltakozókat. „Ahelyett, hogy közeledett volna a tüntetőkhöz, hogy még jobban erősítse a demokráciát és teret adjon újabb demokratikus kezdeményezéseknek, sértően beszélt a tüntetőkről, akikről azt állította, hogy külföldi kormányok és nemzetközi befektetők bábfigurái, akik az ő érdekeiknek megfelelően szeretnék átszabni a török politikát és gazdaságot.” Az internetes közösségi portálokon ettől kezdve a tüntetőkkel szimpatizálók a nevük elé írták a çapulcu szót is. A miniszterelnök szófordulata a városi folklór részévé vált, még vers és könyv is született a çapulcukról. A török sajtót is bejárta egy sikeres üzletember, Cem Boyner képe, aki a tüntetők között egy „Sem jobboldali, sem baloldali nem vagyok, çapulcu vagyok, çapulcu" feliratú táblát tart a kezében. Ezzel kifejezi azt, hogy a Taksim tériek nem egyszerúen a kormánnyal elégedetlenek, hanem a már nekik napok óta udvarló, intézményesült, baloldali ellenzékkel is. A çapulcuk egy új, alternatív ellenzék letéteményeseinek gondolták magukat. A çapulcuk eklektikus mivoltára jó példa egy másik kép, amelyen a téren álló Atatürk Kultúrközpont (AKM) épületén függő transzparensek láthatóak. A müvelődési ház homlokzatán együtt látjuk a szakszervezetek zászlóit a különböző szélsőbaloldali, marxista-leninista pártok és mozgalmak, mint a Nép Megmentése Párt (Halkın Kurtuluş Partisi, HKP) vagy a Szocialista Újjáépítés Pártja (Sosyalist Yeniden Kuruluş Partisi, SYKP) lobogóival, a bal felső sarokban pedig egy radikális anarchista szurkolói csoport, a Çarş1 transzparense feszül.

Miután az Atatürk Kultúrközpont (AKM) a tüntetők kezére került, megnőtt annak szimbolikus jelentősége. Recep Tayyip Erdoğan következő szavainak is ez lehet a magyarázata: 
„az AKM-et leromboljuk, a helyére ugyanazzal az elnevezéssel új operaházat építünk”. Végül az AKM megmenekült a lerombolástól, ám eltávolították onnan a tüntetök jelképeit, helyükre a török nemzeti színek és az államalapító Musztafa Kemál Atatürk képmása került. A téren maradt çapulcuk egy része megtapsolta, a másik fele kifütyülte a török zászló kifüggesztését.

A Taksim téri zászlók eltávolítása után a tiltakozók új jelképet kerestek. Az ország déli részén utcára vonuló nők kezében tüntek fel először a konyhai eszközök, a lábosok és a serpenyők, amivel nem csak átvitt értelemben tudtak „hangot adni” követeléseiknek. Az egyre inkább zavargásokba forduló tüntetések a „fazékforradalommal” egyre rémisztőbb képet mutattak, egyre kevesebben merészkedtek ki az utcára a heves tüntetések hatására. Erdoğan a fazékforradalom hírére is egy, azóta szállóigévé vált mondattal válaszolt: „az edényeknek és az evőeszközöknek mind ugyanaz a hangja”. Ezek után kifejtette, hogy a lakosság fele otthon van, illetve nyugalomra intette az állampolgárokat. A miniszterelnök szavait most már rutinszerüen kifigurázó, ám egyre inkább elszigetelődő ellenzékiek egy, a fenti mondást felidéző gúnydallal vágtak vissza.

A tüntetések második szakasza a jelképek és a verbális támadások hete volt. A kormány oldaláról a jelképek mögött az ottomán múlthoz való ragaszkodás, a vallásos tömegek igényeinek kiszolgálása és egy modern, a kapitalizmus szabályain alapuló városfejlesztés igénye húzódott meg. A baloldali tüntetők is részben konzervatívként viszonyultak a szimbólumokhoz, hiszen az atatürki értékek és a köztársaság megóvása motiválta őket. A verbális harcban egy egyre dühödtebb és feszültebb miniszterelnököt látunk, aki társadalmi támogatottsága biztos tudatában nem válogatja meg a szavait a gúny eszközét használó tüntetőkkel szemben.

\subsubsection{Zavargások}

Június 3-án az események tragikus fordulatot vettek. Egy héttel a Gezi parki falomlás után két tüntető is életét vesztette. Mehmet Ayvalıtaş-t Isztambul ázsiai felén egy gépkocsi gázolta halálra, míg a szír határ közelében fekvő Antiochiában a CHP ifjúsági tagozatának egyik tagja, Abdullah Cömert meghalt a tumultusban. Másnap a fiatal férfi temetése után a tüntetők barikádokat emeltek, és összecsaptak a különleges rendőri egységekkel. Az ellenzéki tüntetők mellett az ingatlanjaikat védő kormánypártiak is súlyosan megsebesültek a megmozdulások során: így járt Abdullah Başçı,is, az AK Parti egyik volt járási pártitkára.

Június 5-e Isztambulban viszonylag békésen telt, hiszen erre a napra esett az iszlám vallás egyik jeles napja, a mirádzs. Miközben a vallásos török családok arra emlékeztek, hogy a 
Próféta csodálatos utazást tett egy éjszaka során Mekkából Jeruzsálembe, majd onnan az égbe, ahonnan isteni parancsokkal tért vissza, egy vitatott vallási vezető, İhsan Eliaçık és kis létszámú csoportja, az „Antikapitalista muszlimok” a Taksim tér közelében, a Boszporusz partján álló Bezmialem Valide Sultan dzsámiba ment, ahol a tüntetőkért fohászkodott. Három nappal a mirádzs ünnepe előtt a Gezi parki tüntetők egyik csoportja behatolt ebbe a mecsetbe, ahol az imaház egyik vezetője szerint cipőben járkáltak a szőnyegen, és sört ittak, ami tiltott dolog az iszlám vallás szerint, a tüntetők viszont azt állítják, hogy csupán a könnygáz támadások során megsérült társaikat igyekeztek elsősegélyben részesíteni, a sörösüvegeket nem ők vitték a dzsámiba, hanem azok később, tőlük függetlenül kerültek oda. A vallásos török rétegeket felzaklató, és őket a tüntetőktől, illetve követeléseitől végleg elidegenítő eset kapcsán 2015 júniusában mondott ítéletet a bíróság. A mecsetben történtekért felelősnek tartott 22 vádlott egy és tizenegy év közötti letöltendő börtönbüntetést kapott. Az AK Partit sokszor iszlamista gyökerünek nevezik, ezért az ellenzéke az iszlám témáját felhasználva is igyekszik azt támadni. Ezek az ún. antikapitalista muszlimok éppen ezért kapóra jöttek. Öket a Gezi parkiak úgy mutathatják fel mint a kormánypárt alternatíváját, egy olyan csoportot, mely az ,iszlám igazi arcát képviseli” a vallás konzervatív és fundamentalista értelmezésével szemben.

Ugyanezen a napon, azaz június 5-én újabb haláleset történt. Adanában egy építés alatt álló hídról lezuhant egy rendőrtiszt, Mustafa Sarı, akit az első hírekkel ellentétben nem a tüntetők löktek a mélybe, hanem baleset áldozata lett.

Az eddig bénultnak tűnő kormánypártiak június 7-én jelentek meg először az utcákon azt követően, hogy hivatalos észak-afrikai körútjáról hazatért Recep Tayyip Erdoğan, akit az arab országokban kitörő lelkesedés fogadott, miközben otthon addig az ellenzéke foglalta el az utcát. $\mathrm{Az}$ Esenboga repülötéren több tízezer fös tömeg várta Erdoğant, aki ezzel összefogta támogatóit, és meghirdette a zavargás békés rendezésének politikáját, kifejtve, hogy nem „marginális csoportok” előtt akar elszámolni, hanem a szavazófülkékben döntést hozó választók előtt. Az AK Parti folyamatos sikerei elkényelmesítették a saját szavazótáborát, ezen belül is a keménymagot. A Gezi parki események paradox módon arra is jók voltak, hogy az AK Parti zárhassa sorait, újra aktivizálhassa és motiválhassa legelszántabb támogatóit. Pár napig alább hagyott a tiltakozások erőssége, ám június 11 -én újfent súlyos harcok színhelye volt a Taksim tér. Komoly visszhangot váltott ki az, hogy egyes külföldi hírtelevíziók, így a CNN és a BBC is élőben közvetítette az eseményeket. Miután a zavargások másnap hajnalig tartottak, és azt az egész világ jól láthatta, hogy a miniszterelnök kénytelen volt leülni a tiltakozók vezetőivel, sőt végül azt is felvetette, hogy népszavazás is dönthetne a Gezi parki beruházásokról. 
A zavargások során sebesült meg és esett kómába egy 14 éves fiú, Berkin Elvan, aki közel egy évvel később életét vesztette a kórházban. A családja szerint kenyérért induló, mások szerint viszont életkora ellenére szélsőbaloldali csoportokkal kapcsolatot ápoló, a tüntetéseken parittyával a kézben, maszkkal az arcán látható fiatalt június 16-án egy könnygáz gránát találta fejen, ami felveti annak a gyanúját, hogy a rendfenntartók fejmagasságban célzott lövéseket adhattak le a tüntetőkre. Az ügyben a nyomozás 2016-ban zárult le. Az ügyészség 42 rendőrt vádolt meg azzal, hogy megtagadva a feletteseik utasítását a tömegbe lőttek. A kisfiú életét kioltó lövést leadó rendfenntartó életfogytiglani börtönbüntetést kapott. Azt az is késlelteti, hogy az eljáró ügyész, Mehmet Selim Kiraz életét vesztette abban a terrortámadásban, amire 2015. március 31-én került sor az isztambuli Igazságügyi Palotában. Az akcióért a számos ország által terrorszervezetként számon tartott Forradalmi Népi Megmentési Párt - Front (Devrimci Halk Kurtuluş Partisi-Cephesi, DHKP-C) tehető felelőssé. „A szervezethez köthető weboldalon közzétettek egy sor követelést, például hogy azonnal tegyenek vallomást a fiú haláláért felelős rendőrök, illetve, hogy fejezzék be a tüntetők ellen indított eljárásokat.” (NÉMET-SZALMA BAKSI, 2015)

A tüntetőkkel való egyeztetések megkezdése azt mutatja, hogy a kormány a közel három hétig zajló eseményekből arra a következtetésre jutott, hogy csak a kompromisszum jelenthet megoldást. Ugyan még a hónap végéig tartottak a megmozdulások, azok intenzitása egyre csökkent, a tiltakozók és a kormány is a békés rendezés, a demokratikus megoldások keresése felé mozdult el.

\subsubsection{A Gezi parki tüntetések háttere}

A Gezi park átalakítása elleni tüntetések és zavargások több mint egy hónapig tartottak, kiterjedtek egész Törökországra, sőt számos más országban is voltak mind a Gezi parkiakkal, mind a török kormánnyal szolidáris demonstrációk.

Láttuk azt, hogy a tüntetések mögött részben a civil és zöld mozgalmak törökországi térnyerése is kitapintható, de ennél is fontosabb az internet, azon belül is a közösségi média hatása. Nem véletlen, hogy a Gezi parki tüntetések kezdeti szakaszában kemény kifejezéseket használó Recep Tayyip Erdoğan a Twitter mikroblog oldalt bírálta, azt katasztrófaként jellemezte. A szolgáltatást 2014-ben egy időre be is tiltották Törökországban. Recep Tayyip Erdogan kormányfő Bursában, március 20-án egy kampányrendezvényen azt közölte, hogy elérhetetlenné teszik a Twittert, s azt is hozzátette, nem érdekli, mit mond a nemzetközi közösség, „mindenki szemtanúja lesz a Török Köztársaság erejének”. (A Twitter és a hasonló 
webes tartalmak nehezebben kontrollálhatóak, mint a hagyományos hírforrások. Ez egyrészt a felhasználók szabadságának szélesedésével jár, de nem ritka az sem, hogy téves információk terjednek el pillanatok alatt. Az İnsan Haber címü híroldal összegyüjtötte mindazt a dezinformációt, amit a közösségi oldalakon nagyon sokan megosztottak. Az egyik ilyen jellegzetesen megtévesztő kép az volt, amelyen tekintélyes tömeg volt látható a Boszporusz hídon, alá pedig azt írták, hogy ez az ázsiai oldalról a Taksim térre tartó emberek sokasága. Ezzel szemben a fotó az Eurázsiai maraton résztvevőit ábrázolja.)

Érdemes azt is megjegyezni, hogy a Gezi parki eseményeket megelőzően, 2013-ban is volt már egy olyan történés, amely a közösségi média felületén egyesítette az AK Parti-kormány ellenzékét. Áprilisban a Fekete-tenger partján található Trabzonban lecserélték a helyi orvosi rendelők tábláit. Ez a hétköznapi eset azért vált országosan ismertté, mert az új feliratokon már nem szerepelt az ország hivatalos rövidítése a T.C. (Török Köztársaság = Türkiye Cumhuriyeti). Ezt követően az ellenzéki oldalon álló törökök a legnépszerübb közösségi oldalakon a nevük elé írták a T. C. rövidítést, hasonlóan ahhoz, ahogy később a çapulcu szót.

A Gezi parki tüntetésekkel foglalkozó tanulmányok vizsgálták a tüntetők motivációit is. Akgün és társai a Zöldek pártjának tagjaival beszélve azt tudták meg, hogy a kormány „elnyomó politikája”, illetve „Erdoğan antipatikus személyisége” vitte ki őket az utcára. (AKGÜN-COP-EMRE-YESEVI, 2014, 11) Ez utóbbi motívum minden második válaszadónál megtalálható volt, akárcsak az, hogy a munka ünnepének hagyományos helyszínén, az átépített Taksim téren már nem lehet tömegrendezvényeket szervezni, hiszen azt a tér védelme érdekében rendeletben tiltotta meg az önkormányzat. Egyesek a kormány szemére vetnek vallási hátterünek tartott intézkedéseket is, így az alkoholforgalmazás és az abortusz szigorítását, mások az alevi vallási kisebbség elleni lépéseket kárhoztatják. Nagy általánosságban elmondható, hogy a tüntetőknél alig-alig kerülnek elő környezetvédelmi témák, így a Gezi park fái, hiszen a „Gezi parki tüntetők a rendszerellenes, internacionalista, kis baloldali csoportosulások tagjai közül kerültek ki”. (TOPAK, 2014, 1942)

\subsubsection{Miért maradt hatalmon az AK Parti-kormány?}

A tömeges tüntetések és a heves zavargások láttán felmerül a kérdés, hogy mi vezethetett oda, hogy mindezek ellenére az Erdoğan-kormány a helyén maradt, sőt a miniszterelnök egy évvel később megnyerte az elnökválasztást is. Az egyik lehetséges válasz az, hogy a már 13 éve kormányzó AK Parti társadalmilag beágyazódott, stabil támogatói körrel rendelkezett. Az sem 
hanyagolható el, hogy az AK Partival szemben a vizsgált időszakban nem volt olyan markáns, karizmatikus vezetésủ ellenzéki párt, amely valós alternatívát jelenthetett volna.

A Gezi parki eseményeket elemző Egeresi Zoltán 2013-ban a következőket írta: „A kormány egyelőre megfelelő legitimitással rendelkezik ugyan, s a szavazók közel fele továbbra is kitart mellette, a jellemzően baloldali tüntetők úgy vélik, hogy a miniszterelnöknek tiszteletben kell tartania az ő akaratukat is. Szerintük nem lenne szabad beleszólnia a magánéletbe (gyerekvállalás, abortusz kérdése, illetve alkoholfogyasztás - mint láttuk, a zavargások előtt épp törvényben korlátozták az alkohol értékesítését), és nem korlátozhatná a sajtószabadságot." (EGERESI, 2013, 11) Ez a helyzetértékelés abból indul ki, hogy Törökország egy müködő demokrácia, a bajok forrását pedig ott kell keresnünk, hogy az erős népi felhatalmazással bíró kormány nem minden esetben veszi figyelembe az ellenzéki szavazók érdekét, világlátását. Az ilyen kormányoknak is meg kell tanulniuk visszakozni azokban az esetekben, ahol komoly népi ellenállással találkoznak, ám ez nehéz feladat, mert ilyenkor úgy tünhet, hogy egy ideológiai természetü dologban engednek, mintha feladnák elveiket. A kompromisszumokhoz azonban nincs szükség az elvek feladására. Söt a nép támogatásának megszerzése ilyen helyzetekben erősítheti a kormány legitimitását. Ezt célozta az is, amikor meglebegtették a népszavazás ötletét.

A Gezi parki tüntetők az eseménysorozat végéig reaktív viselkedést mutattak, míg a kormány ugyan visszalépett egyes helyzetekben, mégis inkább proaktív maradt területfejlesztési és társadalmi síkon egyaránt. (ETE-TASTAN, 2013, 157) Ez azt jelenti, hogy a tüntetők csak reagáltak a politika eseményeire, elítéltek egyes politikai lépéseket, de nem váltak kezdeményezővé, nem voltak képesek a politikát tematizálni, így a lakosság többsége számára nem váltak kormányképes alternatívává. A felkarolható ügyek hiánya nem tette lehetővé, hogy a választópolgárok velük azonosuljanak, ezért inkább a kormány rendteremtését támogatták a koherens jövőkép nélküli, eklektikus tüntetői körrel szemben.

Az AK Parti népszerűségvesztése ellenére megőrizte támogatóinak jelentős hányadát. A 2014-es önkormányzati választásokon a Taksim teret és a Gezi parkot is magában foglaló Beyoğlu kerületben a kormánypárt polgármester-jelöltjét, Ahmet Misbah Demircant a szavazatok 47,8\%-ával választották meg, míg a legjobban szereplő ellenzéki induló csupán $35,2 \%$-ot szerzett. Ha pedig ezt az eredményt a 2009-es voksoláséval vetjük össze, akkor azt is elmondhatjuk, hogy nagyjából 10\%-os javulást könyvelhetett el a városrészben a kormánypárt. A leköszönő miniszterelnök is népszerü maradt a kerület lakói körében, hiszen a szintén 2014ben rendezett elnökválasztáson Erdoğan a szavazatok 53\%-át szerezte meg. 


\subsection{A Gezi Park utóélete}

\subsubsection{A 2013-as év forró nyara}

Törökországban a 2013-as év a kormányzás válságjeleit mutatta mind a nyugati nagyvárosokban, mind az ország délkeleti részén. Ezeken a területeken a biztonsági válság tünetei voltak érzékelhetőek, amelyet részben a két szomszédos országban, Szíriában és Irakban zajló polgárháborús folyamatokkal magyarázhatunk, részben pedig a kurd kisebbség által lakott területeken évtizedek óta fennálló bizonytalansággal, amelyet az előzőekben úgy magyaráztunk, hogy a PKK még nem jött le a hegyekből. Ezen nehézségeket talán a Reyhanli városában bekövetkezett robbantás mutatja meg a legjobban. A szír határon fekvő településen 52 ember életét oltotta ki az a pokolgép, melyet a városháza szomszédságában leparkolt jármübe rejtettek el. Hasonló válságtünet volt a Gezi parki tüntetéssorozat maga is. „Az események láthatóan egy ártalmatlan környezetvédelmi témájú tiltakozásból indultak ki, ahol a zöld fák kivágása ellen tüntettek ott, ahol egy hatalmas bevásárlóközpontot terveztek építeni. Az eredeti demonstrálók többsége békés volt, az a tömeg magasan képzett, politikától távol álló, középosztálybeli emberekből tevődött össze. Később azonban részben a rendőrség túlzottan erőszakos fellépése miatt, részben pedig ideológiai okokból a tüntetésekhez csatlakoztak szélsőséges és erőszakos csoportok is” (ÖZBUDUN, 2014, 157) A heteken át tartó zavargásokban végül öt civil és egy rendőr vesztette életét.

\subsection{2. Ítélethozatal az Ergenekon-perben}

Miután a kormány végül megállapodott a Gezi parki tüntetők többségével, és egy időre stabilizálta hatalmát, eljött az ítélethozatal az évek óta húzódó összeesküvési perben, mely az Ergenekon nevü titkos csoportosulás felett mondott ítéletet. Az Ergenekon csoport, a magas rangú katonatisztekből, értelmiségiekből és újságírókból álló kör az AK Parti kormányzásának kezdeti időszakában a legnagyobb biztonsági kockázatot hordozta magában Törökországban, hiszen a hadsereg 1960 óta többször megbuktatta a polgári kormányt, vagy kényszerítette a politika szereplőit arra, hogy egyik vagy másik párt távozzon a kormányból. 2007-ben a később az Ergenekon-perben állítólag titkos tanuként bevont akkori vezérkari fönök, Yaşar Büyükanit „e-memoranduma” okozott izgalmakat. Az Ergenekon-ügy, és az, hogy a tárgyaláson végül nagyon szigorú ítéletek születtek, a kormányzó AK Partit tovább erősítette pozíciójában, a 
demokratikus rendet megdönteni szándékozó összeesküvőkkel szemben a nemzet megmentőinek mutatkozhattak a török konzervatívok.

Az ultranacionalista és AK Parti-ellenes Ergenekon csoport pere során összevonva vizsgáltak számos már korábban említett büntényt. Az Ergenekon számlájára írható legismertebb fegyveres támadások az alábbiak: mindenekelőtt az Államtanács elleni 2006-os „támadás”, amelyben megölték az Államtanács egyik tagját Mustafa Yücel Özbilgint. Továbbá ide soroljuk a 2007-ben az anatóliai Malatyában a keresztény Zirve kiadó elleni támadást is, melyben három személy vesztette életét, valamint a 2008-2009-es időszak több politikai merényletét, és azt a Molotov-koktélos támadást, amely a Cumhuriyet címü napilap szerkesztőségét érte, illetve azt a próbálkozást is, mely Bartholomeosz ortodox pátriárka életét szerette volna kioltani. 2013. augusztus 5-én született meg az ítélet, melyben a vezérkari főnököt életfogytiglani szabadságvesztéssel sújtották. A döntésről csakhamar bebizonyosodott, hogy a török jog szerint túlzó, ezért Başbuğ-t végül 2014-ben szabadon engedték. Ugyanakkor az ügy arra mindenképpen jó volt, hogy a török igazságszolgáltatás is hozzájáruljon az AK Parti stabilizációs folyamatához. A 2015-ben az Ergenekon-perben hozott ítéletre visszatekintő Recep Tayyip Erdoğan már jóval megbocsátóbb. Egy katonanövendékek elött elmondott beszédében az akkor már a köztársasági elnöki pozíciót betöltő politikus így szónokolt: „ezekkel a műveletekkel az egész ország, beleértve saját magamat is, rossz irányba mentünk... Öszintén mondom, hogy a szívem soha nem volt boldog attól, hogy a vezérkari főnök és a vezető katonatisztek, akiket személyesen is jól ismerek, és akikkel együtt dolgoztam, le lettek tartóztatva és el lettek ítélve.” Ez az idézet jól bizonyítja, hogy az Ergenekon-ügyben a politikai akarat és a jogi folyamat egymásra talált, illetve az akkori miniszterelnök is „rossz irányba ment” az ügy megítélésében. A gondolkodásmód változása mögött az állhat, hogy 2013 nyara óta Törökország kénytelen volt megismerkedni egy, az Ergenekonnál is veszélyesebbnek tűnő, „állam az államban” típusú csoporttal, mely 2013 végén korrupciós botrányokkal operálva komolyabban ingatta meg az AK Parti helyzetét, mint a Gezi parki események és az Ergenekon együttvéve.

2.8.3. A december 17 -ei és 25 -ei események

Sem a Gezi parki zavargások, sem az Ergenekon-összeesküvés nem tekinthető olyan komoly biztonsági kockázatnak, mint az, ami 2013 év végén, december 17-én és 25-én történt Törökországban. Egy már 2012-ben megkezdett nyomozásra hivatkozva a legföbb ügyész által 
kijelölt ügyészségi vezetők számos, az AK Partihoz vagy a kormányhoz köthető üzletembert és politikusok rokonait vették őrizetbe. Az előállított több száz ember között volt Bariş Güler, Muammer Güler belügyminiszter, Kaan Cağlayan, Zafer Cağlayan gazdasági, és Oğuz Bayraktar, Erdoğan Bayraktar környezetvédelmi és urbanizációügyi miniszter fia. Napokkal később kiderült, hogy az ügyészség szerint a korrupt hálózat központi figurája egy iráni származású üzletember, a befolyásos Royal Holdingot is vezető Riza Sarraf volt. Sarrafot és a három miniszter fiát 2014. február 28-án engedték szabadon, velük szemben ejtették a vádakat.

A letartóztatási hullám december 25-én nagyon érdekes fordulatot vett, amikor a miniszterelnök saját fiát, Bilal Erdoğant szerette volna őrizetbe venni a vádhatóság, ugyanakkor Selami Altınok rendőrfönök elégtelennek ítélte meg az ügyészség által kiadott dokumentumokat, és megtagadta az ifjú Erdoğan letartóztatását.

A december 17-ei és a december 25-ei letartóztatási hullám két szinten ártott Törökországnak. Az azt követő politikai válságnak köszönhetően a 61. török kormány vezetője kénytelen volt kabinetjét radikálisan átalakítani. Nem csupán azt a három személyt mentette fel, akiknek a fiai érintettek voltak, hanem összesen tíz miniszter állt fel a bársonyszékből. Az új erős emberek közül érdemes kiemelni Efkan Alat, aki a belügyminiszteri tárcát kapta. Ala, Erdoğan jó barátja és közeli szövetségese amint elfoglalta pozícióját december 25-én arról rendelkezett, hogy a rendőri erők vegyék körbe Bilal Erdoğan házát, és ne engedjék az ügyészséghez hü rendészeti szerveknek letartóztatni a miniszterelnök fiát. A letartóztatási hullám a politikai szinten túl az AK Parti imázsát is erőteljesen rontotta. Mikor 2002-ben létrejött ez a politikai formáció, az egyik kitüzött célja a török politikai élet korrupciótól való megtisztítása volt. Mint már utaltunk rá a dolgozatom elején, a párt névválasztása sem volt véletlen, hiszen az “ak” szó a törökben fehéret jelent, ezzel pedig ártatlanságukat és korrupcióellenességüket igyekeztek hangsúlyozni az alapító politikusok. Az AK Parti számára tehát a sorok rendezésén túl kihívást jelentett az is, hogy hogyan tudják saját választóik felé azt kommunikálni, hogy még mindig ártatlanok, és nem változott meg az eredeti ideológiai irányvonal. Ebből a kettős válságból csak egy kiút mutatkozott: legyőzni azt az új ellenfelet, aki a letartóztatások mögött állhatott: a Gülen mozgalmat.

\subsubsection{AK Parti-kormány kontra Gülen mozgalom}

Fethullah Gülen, a mozgalom névadója egy befolyásos török muszlim vallási vezető, aki Anatólia egyik északkeleti, hegyvidéki régiójában, Erzurumban látta meg a napvilágot 1941ben. Gondolkodásmódját eleinte a 20. század fontos gondolkodója, Bediüzzaman Said Nursi és 
az ő fő müve, a Risale-i Nur (A fény levelei) határozta meg. Innen vezethetőek le Gülen legjelentősebb tanításai is, mint a vallásközi párbeszéd fontossága, a modernitásnak való megfelelés vagy a tudományos kutatás és oktatás előtérbe helyezése. Gülen már nagyon fiatalon követőkre lelt, már az 1960-as években részt vett a Népi házak mozgalmában (halkevleri), melynek célja a néptömegek oktatásán keresztül olyan hátrányos helyzetü társadalmi csoportok támogatása volt, mint a nők és a fogyatékkal élők, valamint kiállt a környezetvédelem mellett is. Az 1971-es katonai puccs idején letartóztatták, annak ellenére, hogy akkor még nem vállalt egyértelmüen politikai szerepet. Az akkor egy mecsetben imavezetői és hitszónoki feladatokat ellátó Gülen fogva tartása mögött ekkor még nem politikai hovatartozása állt, hanem az, hogy a hatalomra jutó katonai junta igyekezett megfélemlíteni a vallásos réteget. A börtönben radikalizálódó Gülent egy évvel később újra letartóztatták, ekkor már le kell töltenie hároméves börtönbüntetését gyújtó hangú beszédei miatt. Az 1980-as katonai hatalomátvétel idején Gülen egyszerűen megszökött akkori állomáshelyéröl, a dél-törökországi Izmirből. Mikor pedig megindult a politikai konszolidáció, újságíróként folytatta az életét. Munkája kapcsán mindkét politikai oldallal jó kapcsolatokat alakított ki, többek között baráti viszonyt ápolt több későbbi miniszterelnökkel, így Turgut Özallal, Bülent Ecevittel és Tansu Çillerrel is.

Eközben sikeresen maga köré szervezte mozgalmát, melyet több néven is emlegetett a török közvélemény: Nur Cemaat (Fény közössége), ami az ihletett adó mü, a Risale-i Nur címére utal vagy Hizmet (Szolgálat), ami pedig a török muszlim vallási csoportosulások legfontosabb értéke. Diákszállókat, egyetemi felvételire előkészítő iskolákat és kulturális létesítményeket nyitott, ezeket hálózatba rendezte, majd olyan nagyszabású rendezvényekkel hívta fel magára a figyelmet, mint a Török Nyelvi Olimpia, amelyre a világ szinte minden országából érkeztek a Gülen-iskolák tanulói.

Követőinek jelentős száma a közigazgatásban dolgozott, aki nem, annak Gülen és mozgalma igyekezet minél jobb állást szerezni. „Az 1990-es évek politikai nyitottsága lehetővé tette a Gülen mozgalom tagjai számára, hogy beszivárogjanak, a jogi-, a nemzetbiztonsági- és az oktatási rendszerbe. A mozgalom kezdett komoly hatást gyakorolni a társadalomra, mivel jelentős számú iskola, sajtótermék és kulturális intézmény volt a kezében, így a kormányzattal is rivalizálni képes csoportosulás jött létre.” (THALJI, 2014) Ali Çarkoğlu ugyanezt a pozíciófoglalást a következő módon magyarázza: „a legfőbb különbség a Gülen-mozgalom és a többi korai pro-iszlamista kör között az volt, hogy az elöbbi hosszú távú befektetésekben gondolkodott azzal, hogy a vele szimpatizáló kádereket kulcspozíciókba helyezte. A mozgalom autonóm befolyásolási stratégiát épített ki, és nem maradt meg az egyszerü „szolgálói” szerepben." (CARKOGLU, 2014, 9) 
Fethullah Gülen mozgalma nemzetközivé vált, és Gülen sokat utazott. Későbbi hazájába, az Egyesült Államokba először 1992-ben látogatott el, ezt követően többször is felkereste Amerikát. Az 1997-es posztmodern puccsot és egészségének romlását követően önkéntes számüzetésbe vonult és azóta Pennsylvania államban él. Egy amerikai újságíró így mutatja be - a Recep Tayyip Erdoğan által sokszor csak ,pennsylvaniai emberként” emlegetett - Gülen életkörülményeit: „a világ valószínüleg legsikeresebb iszlám mozgalmi vezetője egy csöppnyi pennsylvaniai településen, Saylorsburgban él a „Golden Generation Worship and Retreat Center”-ben (Aranykor Vallási és Nyugdíjas Központ), amit sokan csak „táborként” említenek. Az, hogy Gülen Amerikában telepedett le máig komoly vitatéma Törökországban. A vallási vezető azzal érvel, hogy betegségeit csak az amerikai Mayo Clinic specialistái tudják megfelelően kezelni, az ellenoldal szerint viszont Gülen idegen pénzből idegen érdekeket szolgál. (HANSEN, 2013)

Ahogy azt már említettük, a Gülen-mozgalom eredetileg mindkét politikai oldallal jó viszonyt épített ki. Gülen maga volt az, aki a baloldali Köztársasági Néppárt Amerikában elhunyt főtitkárának, Kasim Güleknek a temetési imáját is vezette. Ettől függetlenül hosszú ideig a török közvélemény a nurdzsukat, azaz a Fény közösségének tagjait az AK Partival hozta összefüggésbe. A végső szakítás a mozgalom és a jobboldali konzervatív kormánypárt között akkor vált egyértelművé, mikor az AK Parti elhatározta, hogy bezáratja az egyetemi előkészítő iskolákat, melyek többsége a Hizmethez volt köthető, és ahol a vizsgákra való felkészítésen túl egyre inkább vallási és politikai propagandatevékenység is folyt, ami veszélyeztette a politikai osztály pozícióit. Az ötletet felvető, majd attól először elálló AK Parti 2012 végén dobta be újfent a témát a köztudatba, mondván az ilyen iskolákban megszerezhető tudás mindenkinek jár anélkül, hogy azért külön fizessen. Persze ez feltételezné azt is, hogy megreformálják az amúgy nem túl jól teljesítő török közoktatási rendszert is. Az elökészítő iskolák bezárása egy egész üzleti szektor végét is jelenti. Ahmet Taşgetiren, a népszerü közíró és vallási gondolkodó, aki maga is tagja egy másik, előkészítő iskolákat is müködtető vallási mozgalomnak, például arról írt, hogy egy piacgazdaságban a kormány nem szüntethet meg egy vállalkozói kört egy tollvonással. (TASGETIREN, 2012) A kormány és a Gülen mozgalom között kibontakozó konfliktust jó előre látó Taşgetiren is azzal érvel, hogy a közoktatási intézmények megerősítésével lehet csak a köznevelést helyzetbe hozni, mert ha „,sérülést szenved a Cemaat és a kormány viszonya, akkor sérülést szenved minden társadalmi környezet és Törökország is." (TASGETIREN, 2012)

2013 novemberében az AK Parti-kormány végső elhatározásra jutott, és döntött az elökészítő iskolák bezárásáról. Ezt a lépést Gülenék hadüzenetként értelmezték, Gülen pedig 
egy nyílt levelet adott közre a csoport ellentmondásos nevü internetes oldalán a herkul.org-on. A Herkul elnevezés kétértelmü ebben az esetben. Egyszerre utal az ókori mitológiai alakra, Herkulesre és arra a török kifejezésre, hogy "her kul”, azaz Allah minden szolgája, tehát a muszlim hívők összessége. A „Tovább fogtok haladni az úton megállás nélkül” kezdetű szöveg arra szólítja fel a Hizmet híveit, hogy dolgozzanak tovább rendületlenül, függetlenül attól, hogy mit is hallanak a mozgalom vezetőjéről, aki a későbbiekben meg is átkozta ellenlábasait.

A kormány és Gülen közötti versengés során a közvéleményt egyik leginkább sokkoló epizód az volt, mikor 2013. december 15-én a talán leghíresebb török labdarúgó, Hakan Şükür kilépett az AK Parti frakciójából úgy, hogy megtartotta a mandátumát, amit függetlenként töltött ki. Şükür, aki ismert volt mély vallásosságáról, és aki a miniszterelnök személyes kérésére vállalta el a politikai szerepet, szintén egy nyílt levél keretei között igyekezett döntését megindokolni. A levélben elismerte, hogy az AK Parti számos jó döntést hozott, de hangsúlyozta, hogy egy rosszat is, amikor megtámadta a „Hodzsaefendit”, azaz Fethullah Gülent. A világbajnoki bronzérmes sportoló saját bevallása szerint már húsz éve aktív tagja a mozgalomnak, melynek politikai kötődéséről így vallott a Cemaat által müködtetett, azóta már elérhetetlenné tett Zaman napilap internetes kiadásában: „a népszavazás és a választások idején ezek az őszinte emberek az AK Partit támogatták, ajtótól ajtóig jártak, ezreket fuvaroztak haza, hogy leadhassák voksaikat.”. A labdarúgó itt arra utal, hogy egészen a közelmúltig a török állampolgárok csak Törökországban szavazhattak, a vallási és politikai szervezetek pedig rengeteg erőfeszítést tettek azért, hogy a diaszpórában élő törökség tagjai minél nagyobb számban hazautazzanak leadni voksaikat. Şükür számára a Cemaat, ami eddig az AK Parti barátja volt, hirtelen ellenséggé vált, ám ha azt vesszük, hogy két nappal a focista lemondása után mi történt, akkor ezt csak a későbbi események előszelének tekinthetjük.

A december 17-ei és 25-ei letartóztatási hullámmal,- amit a Gülen mozgalom minipuccsaként kezdtek emlegetni a kormánypártiak- nyílt ellenségeskedés kezdődött a kormány és a gülenisták között. Bár egyesek szerint Fethullah Gülen békejobbot kívánt nyújtani, és 2014 . január 4-én levélben fordult a miniszterelnökhöz, a konfliktus tovább éleződött. Erdoğan válasza egyértelmü volt: nem egyezkedik, véget vet a Hizmet befolyásának. Január 7-én már a kormány lendült támadásba, amikor is új titkosszolgálati dokumentumokra hivatkozva a gülenista körökhöz sorolható ügyészeket, rendőröket és köztisztviselöket tartóztattak le országszerte. A török kormány és Gülen mozgalma között a csatározások tetőpontjaként a 2016. július 15-i puccskísérlet és az azt követő szükségállapotjelölhető ki. Az AK Parti szerint a fegyveres hatalomátvételi kísérlet mögött egyértelműen „Pennsylvania” áll, ezért betiltottak minden olyan szervezetet és sajtóterméket, melyet a Hizmethez kötöttek, illyetve több tízezer 
aktivistát tartóztattak le azzal a váddal, hogy valamilyen módon támogatták az elbukott államcsínyt.

\subsubsection{Marmaray}

A Marmaray, azaz az isztambuli Boszporusz-öböl alatt átvezető gyorsvasúti alagút egyszerre egy presztízsberuházás, egy politikai reklám és egy szavazatszerzési módszer a török kormánypárt részéről. Jól példázza, hogy az AK Parti folyamatos választási sikereit arra igyekszik alapozni, hogy látványosan fejleszti az amúgy 20 éve még nagyon elmaradottnak mondható török infrastruktúrát, és ezt a kampányokban erős érvként is használja. A választók motivációja mögött is sokszor ez sejlik fel. Ugyanakkor az infrastruktúra fejlesztése gazdasági értelemben válságot vetít előre, és ez 2018-ban már jól látszik is a líra értékvesztése kapcsán. Gond ott van, hogy míg az infrastruktúra lassan eléri a nyugati színvonalat, a termelő szektorokban nagyon hiányzik a kormányzati tőkeinjekció, és a gazdaságot inkább a termelés képes mozgatni, mintsem az infrastrukturális befektetések.

A 2013-as év vége és a 2014-es év eleje a heves politikai csatározások mellett a török gazdaság és infrastruktúra fejlettségének komoly megugrásával is jellemezhető. Erre a legjobb példa a Marmaray, a Boszporusz tengerszoros alatt átvezető interkontinentális metró megnyitása. Az isztambuliak évszázados álma valósult meg, mikor a II. Abdulhamid szultán kora óta létező tervek szerint a föld alatt kötötték össze az európai és az ázsiai vasútvonalakat. A 2013. október 29-ei átadó ünnepség egyben kiemelt jelentőségü politikai találkozó is volt, hiszen azon Recep Tayyip Erdoğan miniszterelnökön és Abdullah Gül köztársasági elnökön túl Abe Shinzo japán, Victor Ponta román és Hassan Sheikh Mohamud szudáni kormányfő is megjelent.

A 2004 óta épülő Marmaray átadása nem az egyetlen jelentős infrastrukturális fejlesztés ebben az egy évben. Ide kell sorolnunk egy sor metróépítést is, mint az isztambuli Gezi park szomszédságában lévő Taksim tér összekötését a Marmaray Yenikapı nevü állomásával. Ennek a vonalnak a technikai különlegessége, hogy a szerelvények az Aranyszarv-öböl fölött egy metróhídon haladnak át. Szintén Isztambulban ekkor adták át a buszállomást az Olimpiyatköy nevű külvárossal összekötő $21,7 \mathrm{~km}$ hosszú metróvonalat. Ankarában a legfontosabb metróvonalat mindkét végén 15-15 km-rel hosszabbították meg, Bursában 8 km új szakasz épült, Izmir hálózata három új megállóval gazdagodott 2014 első három hónapjában. Ez a sok példa is jól mutatja, hogy a fejlesztések nem csupán a Marmarayhoz hasonló kiemelt beruházásokra koncentrálnak, hanem a szegényebb néptömegek által lakott külvárosokat is igyekeznek elérni, amivel az AK Parti népszerüsége egyértelmüen nő ezekben a kerületekben. 
A fejlődés a gyorsvasúti hálózat esetében is egyértelmü. Az első ilyen vonal 2011-ben került átadásra Ankara és a közép-anatóliai nagyváros, Konya között. 2014-ben már a fővárost Eskişehiren és Izmiten keresztül Isztambullal összekötő szakaszon is megindult a közlekedés, így a két török nagyváros közötti menetidő kevesebb, mint a felére csökkent. Emellett rohamtempóban haladt a repülötér-fejlesztési projekt is, melynek keretében Kastamonu, Bingöl és Şırnak városaiban nyílt légikikötő. Ez a lépés azt mutatja, hogy az AK Parti-kormány a keletanatóliai fejletlenebb régiókat is megpróbálja bekötni a török gazdaság vérkeringésébe.

Néhány más fontos projekt 2013-14-ben a tervezés és a kivitelezés fázisában volt. Ilyen az isztambuli harmadik repülőtér és a Boszporuszon átívelő harmadik híd vagy a várost megkerülö, és a Boszporuszt tehermentesítő új csatorna is.

\subsubsection{Népszerü internetes oldalak betiltása}

Világszerte jól látszik, hogy az új média és a közösségi oldalak egyre inkább kihívást jelentenek a hatalom gyakorlói számára, hiszen egyre gyorsabbá teszik az információáramlást, amit így egyre nehezebb is ellenőrizni. A 2010-es évek elejéig jellemző volt, hogy az ellenzék sokkal ügyesebben használta ki a közösségi média adta lehetőségeket és gyorsabban, ám ellenőrizetlenül tudtak információkat eljuttatni egyre több emberhez. Ahogy a világ más pontjain is, Törökországban is felmerült az internet szigorúbb szabályozása, ám nagy kérdés, hogy ezek a korlátozások valóban hasznosak-e, vagy csak még jobban elidegenítik az internet használóit a politikától és a politikai elitektől.

2014-ben Törökországban több közösségi portál elérését blokkolták egy időre. Az első célpont március 20-án a legismertebb mikroblog-szolgáltató, a Twitter volt: Erdoğan egy bursai választási nagygyülésen azt mondta, hogy ,a Twittert gyökerestől fogjuk kitépni” A miniszterelnök az egy héttel későbbi önkormányzati választások előtti kortesbeszédében úgy tartotta, hogy ezek az oldalak úgy müködnek, mint egy nemzetközi összeesküvés. Aláhúzta, hogy a szólásszabadság nem jelentheti azt, hogy az állam titkait kiteregessék nemzetközi fórumokon. A kormányfő itt azokra az állítólagos hangfelvételekre utalt, melyek őt és kormányának tagjait tüntették fel úgy, mintha korruptak lennének. Erdoğan szenvedélyes Twitter-ellenessége nem találkozott a kormánypárt egyértelmü tetszésével. Még Abdullah Gül államelnök is kénytelen volt ironikusan megjegyezni egy Twitter-bejegyzésében, hogy „remélem, ez a tilalom nem lesz hosszú életü”. Egy héttel később a legnépszerübb videómegosztó platform, a YouTube jutott a Twitter sorsára, hiszen azon olyan felvételek láttak napvilágot, melyek szerint Ahmet Davutoğlu a török titkosszolgálatok vezetőjével egy 
esetleges szíriai katonai beavatkozás esélyeit latolgatták. A felvételek hitelessége máig kétséges, és azt sem lehet tudni, ki publikálta azokat.

Az internet korlátozása számos török fiatalt idegenített el a kormánytól, ám ugyanakkor lehetővé tette, hogy ne szivárogjon ki több kényes adat a kormány belső köreiből akkor, amikor a közelgő helyhatósági választásokon az AK Parti azt szerette volna demonstrálni, hogy a Gezi parki tüntetések után is képes megőrizni pozícióit.

\subsection{7. Önkormányzati választások}

Nem volt az ötévente tartott önkormányzati választások között olyan, amelyet ennyire várt a török közvélemény, mint a 2014. március 30-ára kiírt voksolást. A választás szempontjából fontos fejlemény volt az is, hogy 16 település (Aydın, Balıkesir, Denizli, Hatay, Malatya, Manisa, Kahramanmaraş, Mardin, Muğla, Ordu, a magyarok számára Rodostóként ismert Tekirdağ, Trabzon, Şanlıurfa és Van) megkapta a megyei jogú város címet, és ezzel ott ún. „,nagyvárosi közgyülésekre” lehetett szavazni.

„Ez a választás a december 17-i letartóztatási hullám után az AK Parti iránti bizalmi szavazássá lényegült át. Március 30-án nem a települési képviselőtestületek összetételéről fognak dönteni, hanem Erdoğan jövőjéről” (ETE-AKBABA-DALAY-ERSAY-KANATÜSTÜN, 2014, 9)- mondta ezt Hatem Ete. Egyúttal a jelöltállítás folyamatával kapcsolatban is tett egy fontos megjegyzést: ,az AK Parti még azokon a településeken is erős jelölteket indít, ahol csekély a győzelmi, illetve szavazatai maximalizálásának az esélye.” (ETE-AKBABADALAY-ERSAY-KANAT-ÜSTÜN, 2014, 10) A választási eredmény végül nem csupán azt bizonyította, hogy az AK Parti képes volt megőrizni a helyét, hanem komoly siker is volt a kormánypárt számára, hiszen 2009-hez képest 5\%-kal 38,39\%-ról, 43,39\%-ra növelte támogatói arányát. A két parlamenti ellenzéki párt, a CHP és a MHP is jobban teljesített, mint öt évvel azelőtt. A 2014-es helyhatósági választások vesztesei a kis pártok voltak, így az iszlamista Boldogság Párt (SP), a demokraták (DP) és a baloldali demokraták. (DSP).

Az AK Partit és magát Recep Tayyip Erdoğant sok kritika érte ebben az időszakban. Leginkább azt vetették a szemükre, hogy az ellenfeleikkel vívott küzdelemben olyan eszközöket is megengedtek maguknak, mint a Twitter vagy YouTube betiltása. Az AK Parti győzelmét követően a politikai elemzők azt próbálták kideríteni, kikre szavaztak a gülenisták. Miután nagyon magas (90\% feletti) volt a részvételi arány, nagyon nehéz volt megbecsülni ezeket a preferenciákat, hiszen „a március 30-ai választások a kortárs török politikatörténet egyik legfeszültebb és legpolarizáltabb választása volt tekintettel a politikai közbeszédre, a 
retorikára, az attitüdökre, s a politikai vezetőkre.” (KEYMAN, 2014, 21) Az ekkor még nehezen megválaszolható kérdésre a későbbi elnökválasztás adja meg a választ: a maradék gülenista hátország is elhagyta az AK Partit.

\subsubsection{A somai bányakatasztrófa}

Az önkormányzati választások után úgy tünt, hogy az AK Parti helyzete megszilárdult, ám két katasztrófa komoly csapást mért a kormányra és a kormánypártra. Az első, egy belföldi esemény a Manisa megyei Somában bekövetkezett bányakatasztrófa volt, ahol a hivatalos statisztikák szerint 301 ember vesztette életét, bár egyes politikusok, így az iszlamista Nagy Egység Pártját (Büyük Birlik Partisi, BBP) vezető Mustafa Destici szerint az áldozatok száma elérte a 344 föt.

A somai szénbányát több más hasonló létesítménnyel együtt az AK Parti kormányzásának első éveiben privatizálták. A többi bányánál már többször is tüntettek a dolgozók a biztonsági berendezések elégtelensége miatt. Sőt az ellenzéki Köztársasági Néppárt egy parlamenti vitanapra és vizsgálóbizottságra is javaslatot tett, ám ezt az ötletet a többség leszavazta. A privatizációs folyamatot és a katasztrófára adott lassú kormányzati választ sokan kritizálták. Annak ellenére, hogy a kormány háromnapos nemzeti gyászt rendelt el, és hogy a dzsámikban is a pénteki imádságok során az elhunytakért fohászkodott az ország, Somában nem nyugodtak meg a kedélyek. A kormány ügyetlen kommunikációja is csak olaj volt a tüzre. „Annak ellenére, hogy a kormány volt a katasztrófa egyik legfőbb felelőse, Erdoğan úgy viselkedett, mintha ő lenne a kezdeményező. Rosszul mérte fel a helyzetét, mikor egy önmagát védelmező, gyújtó hangú beszédet mondott, melyben így szólt a hozzátartozókhoz: ,az ilyen katasztrófák hétköznapiak”. (ÖZTÜRK, 2014, 114) Egy másik zavaró tényező volt az, amikor a beszéd ellen is tiltakozó helyiek tüntetésén Yusuf Yerkel a kormányfő tanácsadója belerúgott egy olyan demonstrálóba, akit már földre tepert a rohamrendőrség. Ez a kép sem járult hozzá ahhoz, hogy az AK Parti-kormány az eset után úgy mutatkozhasson a közvélemény előtt, mint aki mindent megtett a helyzet mielőbbi konszolidálásáért.

\subsubsection{Az ISIS támadása a moszuli török konzulátus ellen}

A török kormány számára a másik nagy kihívás egy külföldi eset volt. 2014. június 11-én az Iraki és Szíriai Iszlám Állam (ISIS) nevezetü terrorszervezet mintegy 900 fegyverese lerohanta az észak-iraki Moszulban az ottani török konzulátust miután hatalmába kerítette ezt a 
kulcsfontosságú települést. Öztürk Yılmaz konzult és negyvenkilenc munkatársát túszul ejtették és ismeretlen helyre hurcolták. A diplomaták kiszabadításáért a török titkosszolgálat egy több hónapos mủveletet indított, melyben az akkori külügyminiszter, Ahmet Davutoğlu is részt vett. A foglyokat végül akkor sikerült kiszabadítani, mikor már Davutoğlu ült a miniszterelnöki székben. Mivel a legtöbb nyugati nemzetnek nem sikerültek a hasonló túszszabadító akciói, elmondhatjuk, hogy ebben a tekintetben a török kormány sikeresebb volt, mint mások.

\subsubsection{Elnökválasztás}

A Török Köztársaság 90 éves történetében először fordult elö, hogy a szavazók közvetlenül választhatták meg az államfőt. 2014-ig ez a Nagy Török Nemzetgyülés joga és kötelessége volt. A 2007-es alkotmányreform lehetővé tette ezt a változást, ám a köztársaság parlamentáris jellegén nem változtatott. A leginkább szimbolikus jogkörökkel bíró elnöknek legalább 40 éves török állampolgárnak kell lennie, s egyetemi végzettséggel kell rendelkeznie.

2014. augusztus 10-én a szavazópolgárok három jelölt nevével találkozhattak a szavazólapon: Recep Tayyip Erdoğan indult a kormányzó AK Parti színeiben, a két parlamenti ellenzéki párt, a baloldali Köztársasági Néppárt és a nacionalista Nemzeti Akciópárt meglepő módon közös jelöltet állított Ekmeleddin İhsanoğlu személyében, míg a főleg a kurd kisebbség jogainak képviseletével azonosított, viszonylag új Népek Demokratikus Pártja (Halkların Demokratik Partisi, HDP) Selahattin Demirtaşt indította. Erdoğan jelölése nem volt meglepetés, İhsanoğlué mindenképpen az volt. İhsanoğlu Kairóban született, komoly karriert futott be tudósként, egyetemi tanárként és diplomataként, 2004 óta ő vezette az Iszlám Konferencia Szervezetét. Nagy kérdés volt tehát, hogy a nacionalista hátterü, vallásos muszlim jelölt megfelel-e a kemalistáknak, illetve a „szürke farkasoknak” nevezett nacionalisták elfogadják-e a baloldallal kötött „kényszerházasságot”. Demirtaş a zaza etnikumhoz tartozó sztárügyvéd számára a legfőbb kihívás az volt, hogy eléri-e az ún. baraj-t, azaz a 10\%-os parlamenti bejutási küszöböt. Azaz a HDP számára az elnökválasztás csupán egyfajta teszt volt, amelynek során azt vizsgálták, hogy érdemes-e nekik a 2015-ös parlamenti választásokon pártként elindulniuk vagy jobb lesz független jelölteket állítaniuk. A szavazatmaximálás érdekében a HDP nyitni próbált a Gezi parkiak felé is.

Az eredmények analízise egyértelműen Erdoğan sikerét mutatja. A távozó miniszterelnök a voksok 51,79\%-ával már az első körben megnyerte a szavazást. Első ránézésre ez az eredmény meggyőző, de az is kiolvasható belőle, hogy Erdoğan személye sokkal népszerübb, 
mint a pártja. Ha a márciusi eredményekkel vetjük össze, akkor mintegy 8,5\%-os különbséget láthatunk, ami intő jel is lehet az AK Parti számára, hogy egy nála kevésbé karizmatikus vezetővel bajba kerülhet az AK Parti a következő parlamenti választásokon. İhsanoğlu a maga 38,44\%-ával egyértelmüen kudarcot vallott, hiszen még csak arra sem volt képes, hogy második fordulós küzdelemre kényszerítse Erdoğant.

\subsubsection{Az Erdoğan-kormányok vége}

A Gezi parki tüntetéseket követő év tele volt fordulatokkal a török belpolitikában. Jellemző volt erre az időszakra az, hogy a Gezi parkiakkal kötött kompromisszum és a két választás eredménye megerősítette a kormány pozícióját, de voltak komoly kihívások is számukra, így a katonai elittel fennálló nézetkülönbségek (Ergenekon), egy „állam az államban”-típusú csoportosulás (Gülen-mozgalom) és különböző katasztrófák, mint az, ami a somai szénbányában és a moszuli konzulátuson történt.

2013 vége és 2014 eleje egyben az utolsó olyan időszak is volt, amikor Recep Tayyip Erdoğan töltötte be a török miniszterelnöki tisztséget, hiszen megválasztották a köztársaság elnökévé. Az AK Parti-kormányok eddigi története az ő személyes ügye is. „Erdoğan már több mint egy évtizede volt hatalmon. Olyan iszlamista vezető, aki példakép lehet a muszlim világ számára, hiszen képes összeegyeztetni a hitet a demokráciával.” (ARANGO, 2014) Egy másik szakértő így látta a miniszterelnököt: ,politikai személyiségét több mint húsz év óta a marginalizált, külvárosi néptömegek felkarolásával alapozza meg, továbbra is ő azon széles néptömegek egyetlen képviselője, akiknek nincs tőkéjük ahhoz, hogy saját problémáikat artikulálják.” (YEL-NAS, 2013, 180) Recep Tayyip Erdoğan köztársasági elnöki megbízatását az elnöki rendszerre való áttérés lehetővé tételére használta fel. A török alkotmány módosításáról szóló 2017-es népszavazás ugyan kis többséggel, de megerősítette ezt az irányvonalat. Az új rendszer mihamarabbi bevezetése és saját politikai helyzetének további stabilizálása érdekében az Erdoğan-adminisztráció úgy döntött, hogy mind a nemzetgyülési-, mind pedig az elnökválasztás időpontját előre hozzák.

Az AK Parti ellenzéke a 2018-as előrehozott választások előtt, a 2016-os puccskísérlet okozta sokkhatás okán jelentősen átstrukturálódott. A nemzeti oldal egy része, köztük a Devlet Bahçeli vezette nacionalisták és a Nagy Egység Pártja (BBP), nyíltan a kormány oldalára állt. Az ellenzéki térfélen pedig egy sokszínü koalíció körvonalazódik, amiben egyaránt helyet kap a Köztársasági Néppárt, a volt belügyminiszter, Meral Akşener asszony vezetésével a MHPből kivált Jó Párt (IYI) és az iszlamista gyökerűnek mondott Boldogság Párt (SP). „Erdoğan és 
a szövetségesei ennek az új ellenzéknek az egyik aspektusát mindenképpen alulértékelték: az igazi nyugatos liberálisokat, akik marginálisak maradtak, de egyszer majd képesek lehetnek háttérbe szorítani az autoriter, szekuláris baloldalt mind politikai, mind normatív síkon." (MUFTI, 2014, 39) Az AK Parti demokratizálási törekvései nyitottabbá tették a török társadalmat, s ennek köszönhetően a nyugatias, liberális értékek is megjelentek, amelyeknek a képviseletét mások mellett a feltörekvő HDP is szeretné ellátni. Ez az „új ellenzék” tehát egy heterogén tömeg, mely sokféle ideológiai alapon áll, egyszerre képvisel etnikai, vallási és szexuális kisebbségeket, és ezzel képes megszólítani az elégedetlenek egy részét. Ennek ellenére nem mondhatjuk, hogy a klasszikus ellenzék komolyabban veszítene a súlyából ezen új csoportok megjelenése következtében.

\subsubsection{A 2015-ös választás értékelése}

Recep Tayyip Erdoğan államfővé választása után továbbra is a török belpolitika meghatározó alakja maradt. Tette ezt annak ellenére, hogy a török alkotmány a köztársasági elnöknek inkább csak ceremoniális jogköröket biztosít. Az Erdoğantól a pártvezetést és a miniszterelnökséget átvevő Ahmet Davutoğlu bár karizmatikus vezetővé vált, nem kívánt Erdoğannal szembeszállni. A 2014 augusztusa után időszakot a HDP megerősödése és a gülenistákkal folytatott harc jellemezte.

Az AK Parti hatalma szempontjából a változást a 2015-ös parlamenti választás hozta. Ez alkalommal a párt a szavazatoknak csak 40,8\%-át tudta megszerezni, amely a HDP bejutása miatt nem volt elegendő a kormányalakításhoz. Ennek okai között meg kell említeni az előző két év belpolitikai válságainak hatását. A sétatéri események, a Fethullah Gülen mozgalom által előidézett botrányok csökkentették az AK Parti népszerüségét. Sok, korábban az AK Partira szavazó állampolgár gondolta úgy, hogy ezúttal más pártra kellene adnia a voksát. Ezekböl két párt profitált: a nacionalista MHP és a baloldali, kurd-bázisú HDP.

Az előbbire elsősorban a törökök szavazták át, döntésüket megkönnyítette, hogy a MHP is nagy jelentőséget tulajdonít a hitnek és szintén jobboldali párt, így az ellenzéki pártok közül karakterében a legközelebb áll az AK Partihoz. A valamilyen okból elégedetlenek egy része más pártokra, például a szintén iszlamista Saadet Partira is adhatta szavazatát, azonban ez utóbbi továbbra is marginális maradt.

Mint említettük, az elégedetlenek egy része a HDP-re szavazatott át. Ez elsősorban az ország keleti megyéiben történt, ahol a kurdok többségét sikerült a HDP karizmatikus vezetőjének, Selahettin Demirtașnak meggyőznie arról, hogy érdemesebb nekik erre a pártra 
szavazniuk. A HDP a 2010. júniusi választásokon sikeresen integrálta a kurd szeparatistákon túl a városi értelmiség és a liberálisok egyes csoportjait is, így bejutási küszöb feletti eredményeket ért el. 2010 júniusában a voksok 13,1\%-át gyüjtötte be, míg a novemberi, megismételt választásokon is sikerrel vette ezt az akadályt és 10,7\%-kal parlamenti párt maradt. Persze az is igaz, hogy a párt vezetőit és számos képviselőjét ezután terrorizmus vádjával letartóztatták. A párt társelnöke, Selahattin Demirtas disszertációm írása pillanatában is a rácsok mögött van.

A pártprogram kifejezetten nem a kurdoknak szólt, hanem országos pártként jelent meg, amely az összes állampolgár pártja kíván lenni. Az eredmények tekintetében a HDP abbéli igyekezete, hogy megnyerje a Gezi parkiakat, a liberálisokat, a baloldaliak egy részét, azt láthatjuk, hogy sikeres volt. A párt a szavazatok 13,12\%-át tudta megszerezni, amivel az összes korábbi kurd párt eredményét megelőzve 80 képviselői helyre tett szert. Ez az eredmény azonban nem születhetett volna meg a nyugat-törökországi török szavazatok nélkül. Nélkülük valószínüleg a párt nem jutott volna be a parlamentbe.

A 2015-ös év során Törökországban két parlamenti választást is rendeztek, mivel a június 7-én tartott voksolás során négy párt is bejutott a nemzetgyülésbe, és nem jött létre stabil kormánykoalíció. A politikai válsághelyzet feloldása érdekében november elsején előrehozott választásokra került sor, melyen az $\mathrm{AK}$ Parti tovább növelte támogatottságát, a szavazatok 49,5\%-ával bebiztosította magának az abszolút többséget, hiszen az 550 képviselői helyből 317-et megszerzett. A így létrejött egypárti kormány stabilitását bizonyítja az is, hogy a 2016. július 15-i katonai puccskísérlet után is hatalmon maradt.

Az AK Parti gazdasági, szociális politikájának és a demokratizációnak a sikere, hogy tizenháromév után is a legnagyobb párt tudott maradni. Még mindig 18867411 szavazatot tudott szerezni, ami nagyjából 3 millióval kevesebb, mint amit 2011-ben kapott. Az átszavazások ellenére a szavazók többsége kitartott a párt mellett, s elkötelezett Davutoğlu és Erdoğan politikája mellett.

\section{Fontosabb belpolitikai események Törökországban 2015 és 2018 között}

Törökországban 2015 és 2018 között több kiemelkedően fontos politikai esemény zajlott le, ám ezek között kettő olyan van, mely hosszú távon is befolyásolja a Török Köztársaság jövőjét. Az egyik ezek közül a politikai rendszer gyökeres átalakítása, azaz az elnöki rendszerre való 
áttérés. A másik egy politikai kataklizma, mely új támogatói egységet teremtett a kormánypárt körül, részben átalakította a török pártrendszert, illetve már az első évfordulóján is nemzeti ünnepként emlékeztek meg róla. Ez utóbbi esetben a 2016. július 15-i puccskísérletről van szó. A többi, kisebb jelentőségü történés is ezek fényében és ezekkel összefüggésben értelmezhető, illetve már régebbi trendek folytatásának tekinthető. Ilyen a hullámzó intenzitású fegyveres konfliktus a kormányerők és a PKK terroristái között.

\subsection{Az elnöki rendszerre való áttérés}

Az elnöki rendszerre való áttérés és annak előkészülete (alkotmánymódosítás, népszavazás és elnökválasztás) radikálisan alakítja át a török állam működését, és mivel egy adott politikus személye köré szervezi a szisztémát, magában rejti annak veszélyét, hogy végsősoron a köztársaság meggyengül, mert a döntéshozatali folyamatból kiiktatják a fékeket és az ellensúlyokat. Az elnöki rendszerü köztársaság működése azt feltételezi, hogy az elnök rendkívüli jogkörökkel rendelkezik, mindenképpen több lehetősége van a döntéshozatali folyamat befolyásolására, mint a parlamentáris rendszerben. Ebből pedig az fakad, hogy vagy eleve szükség van egy keménykezü, karizmatikus vezetőre ahhoz, hogy a szisztéma müködjön, vagy maga rendszer termeli ki az ilyen jellegü politikust.

Törökországban az elnöki rendszerre való áttérés kérdése már évtizedekkel az AK Parti hatalomra jutása előtt felmerült. Turgut Özal 1989-ben megválasztott egykori köztársasági elnök azzal érvelt, hogy társadalmi, politikai és müszaki fejlődés olyannyira átalakította Törökországot, hogy célszerü lenne a politikai rendszert megreformálni. Az alapvetően konzervatív beállítottságú Özal azt is megjegyezte, hogy a lelkiismereti- és vallásszabadság szempontjából is kívánatos lenne az elnöki szisztémára való átállás. Özal felvetését az 1980-as évek komoly felhördülés fogadta, ugyanakkor az elnök az Öböl-háború idején újra előhozta a témát mondva, hogy egy fegyveres konfliktus esetén könnyebben kormányozható így az ország. (KAYA, 2017, 28)

Az elnöki rendszerre való áttérés mögött nem csupán Özal politikai öröksége, és annak az AK Parti politikai irányvonalára gyakorolt hatása húzódik meg, hanem több más, nem elhanyagolható tényező is. Ezek közül az egyik az, hogy a török kormánypárt szerint az 1982ben a puccsisták által megfogalmazott, ám még mindig hatályos alkotmány túlzó jogköröket biztosított a nemzetgyülésnek, amit így az elnök nem képes megfelelő módon ellenőrizni. Ezen kívül az AK Parti megítélése szerint az is a rendszer átalakítása mellett szól, hogy már 2007 óta általános és titkos választójog alapján a nép dönt a köztársasági elnök személyéről. Ezzel a 
politikai rendszer „,kétfejüvé” vált, azaz egy erős parlament mellett megjelent egy egyre erősödő elnöki intézmény is, ez pedig hosszú távon nem képes garantálni a köztársaság jó kormányozhatóságát. (GÜLENER-MIŞ, 2017, 8)

A kormányzó AK Parti, illetve a 2016. július 15-i puccskísérlet után a kormányt támogatni kezdő ellenzéki MHP politikusai a fenti érvek mellett még két fontos politikai bizonytalansági tényezőt is megemlítenek, mikor arról kérdezik őket, miért is volt szükség a rendszer gyökeres átalakítására. Ezek közül az első az, hogy a régi rendszer nem képes teljes mértékben szavatolni a köztársaság stabilitását. A második pedig az, hogy a döntéshozatali mechanizmus túl lassú, akut válsághelyzetekben, mint amilyen a fegyveres hatalomátvételi próbálkozás is volt, nem képes időben reagálni. (GÖNENÇ, 2018, 2)

Az AK Parti által túlzott parlamentarizmusként leírt régi rendszer nem csak azáltal változik meg 2017-ben Törökországban, hogy kiépül az elnöki szisztéma, hanem azáltal is, hogy a Nagy Török Nemzetgyülés jogköreit megkurtítják, társadalmi és politikai szerepét megváltoztatják. Az AK Parti értelmezésében mindez az állam egységének helyreállításáról szól, és arról, hogy elkerülhető legyen az olyan helyzet, mikor egyes politikai kérdésekben mind az elnöknek, mind pedig a parlamentnek döntési jogköre van. Mindemellett átszabják a parlamentet magát is. Erre a legjobb példa az, hogy a képviselők számát 550-ről 600-ra emelik, a választhatósági alsó korhatárt pedig leviszik 18 évre. (GÜLENER-MIŞ, 2017,9) Az új rendszer mindamellett, hogy bizonyos szempontból korlátozza a parlament hatalmi törekvéseit, négy olyan alkotmányos lehetőséget is a TBMM kezébe ad, mellyel az elnök ellenőrizhető, számon kérhető. Ezek az utak azt teszik lehetővé, hogy a nemzetgyülés vizsgálatot avagy nyomozást indítson az elnökkel és a politikájával kapcsolatban. Szükség esetén a képviselök írásbeli kérdést is feltehetnek a köztársaság elnökének, illetve a plenáris ülésen is megvitathatják az elnök által hozott döntéseket. (GÜLENER-MIŞ, 2017, 12)

Az AK Parti rendszerátalakító tevékenysége részben merít a nemzetközi példákból, így az Amerikai Egyesült Államok berendezkedéséből, de néhány helyen el is tér azoktól. A születőben lévő új török szisztéma sajátosságai közé tartozik az, hogy az alkotmánymódosítás pontosan meghatározza, hogy ki lehet elnökjelölt. Ezek szerint csak negyvenedik életévét betöltött, felsőfokú végzettséggel rendelkező, a nemzetgyűlési választások jelöltállításai szabályainak is megfelelő török állampolgárból válhat köztársasági elnök. Az elnök megválasztásához az egész országot egy választókerületnek kell tekinteni, és szavazattöbbséget kell elérni. Ha ez nem áll fenn, akkor második fordulót kell tartani. A török nép az elnököt öt évre választhatja meg, az adott politikus egyszer töltheti be újra ezt a tisztséget, azaz összesen tíz évig kormányozhatja elnökként az országot. Az elnök fontos feladatköre a miniszterek 
kiválasztása és kinevezése, illetve felmentése, ugyanakkor a miniszterek személyét a nemzetgyülés is megerősíti. (KAYA, 2017, 36-37)

A reformokat követően a török köztársasági elnök nem csupán a köztársaság feje és egyszemélyi felelőse az állam jó müködésének, hanem számos kulcsfontosságú jogkörrel is fel lett ruházva. Ezek közé tartozik az, hogy a köztársasági elnök határozza meg az ország bel- és külpolitikai irányvonalát, ha jónak látja, akkor felszólal a Nagy Török Nemzetgyülés nyitó ülésnapján, illetve bel- és külpolitikai kérdésekben levéllel fordulhat a képviselökhöz. A külpolitika tekintetében egy személyben képviselheti az országot, tárgyalhat kül- és belföldön más országon képviselöivel. Ebbe a jogkörbe beletartozik az is, hogy a Török Köztársaság nevében egyszemélyben aláírhat nemzetközi szerződéseket, egyezményeket. Ennél komolyabb jogkör az, hogy ő hagyja jóvá a megszavazott törvényeket, szükség esetén visszaküldheti azt a parlamenthez megfontolás vagy módosítás céljából. Hasonlóképpen joga van a jogszabályokat megküldeni alkotmánybírósági normakontrollra, illetve azok tárgyában népszavazást is kezdeményezhet. A törvényhozás megfelelő müködése érdekében a nemzetgyülést feloszlathatja és elörehozott választásokat is kiírhat. A köztársasági elnök Törökországban a fegyveres erők föparancsnoka, ő nevezi ki a tiszti kart, az ő joga rendkívüli állapotot vagy statáriumot bevezetni. (KAYA, 2017, 37-38) Fontos persze megjegyezni, hogy az új szabályozás szerint a rendkívüli állapot, azaz az OHAL idején -szemben az eddigi gyakorlattalnem korlátozhatók az alapvető emberi és politikai jogok gyakorlása. (DEMIR-ÇOHADARGÖK, 2017, 150)

A hadsereg mellett a török köztársasági elnök a felsőoktatás egyszemélyi felelőse is. Ö nevezheti ki az állami egyetemek vezetőit és ő állítja össze a Rektori Konferencia tagságát. (KAYA, 2017, 37-38) Az elnök komoly lehetőségeket kap arra is, hogy személyesen befolyásolja az ország gazdasági- és pénzügyi politikáját azzal, hogy az elnök hatáskörébe rendeli az alkotmány a költségvetési törvény megalkotását. Ezt az elnök a pénzügyi év vége előtt legalább hetven nappal köteles benyújtani a nemzetgyülésnek, mely azt megtárgyalja, és ha jónak látja megszavazza. Szükség, illetve válság esetén az elnök átmeneti költségvetést is javasolhat. (GÜLENER-Mİş, 2017, 17)

Összességében az mondható el, hogy a török köztársasági elnök rendkívül széles jogkörökkel bír, az élet több területén is ő határozza meg egyedül az ország sorsát. Amíg eddig számos fék és egyensúly volt képes a politikai stabilitást garantálni, addig ezután már sok esetben az elnök személyes meggyőződésétől és belátásától fog függeni a köztársaság müködése. 
Az újfajta elnöki rendszerben az elnök politikai szerepe is megváltozik. Míg a parlamentáris demokráciákban az elnök a nemzet szimbolikus vezetője, a nemzet egységét testesíti meg, többnyire nem lehet párttag, nem képviselheti egy politikai párt érdekeit sem. Ez volt igaz a 2017 előtti Törökországra is. Ugyanakkor az elnöki rendszerben ez is megváltozik, az elnököt az egyik vagy másik politikai párt jelöltjeként választják meg, az adott jelölő szervezet politikáját testesíti meg, ülteti át a gyakorlatba. Ebből fakadóan a török köztársasági elnök 2017 után lehet akár párttag is. (GÜLENER-Mİş, 2017, 8) Ennek megfelelően Recep Tayyip Erdoğan török köztársasági elnök 2017. május 2-án visszaléphetett abba a Igazságosság és Fejlődés Pártjába, amit a 2000-es évek elején -többek között- ő maga alapított. Ezt követően pedig a párt 3. rendkívüli tisztújító kongresszusán, 2017. május 21-én újra az AK Parti elnöke lett.

Az elnöki rendszerre való áttérés egy hosszútávú és rendszerszintü folyamat, mely évtizedekre megszabhatja a köztársaság jövőjét, ugyanakkor nem lehet eltekinteni attól, hogy ez az új berendezkedés Recep Tayyip Erdoğan személye körül kristályosodik ki. Ez pedig azt jelenti, hogy nélküle kiszámíthatatlan a jövőbeli müködése, de azt is, hogy az ide vezető út és maga a rendszer lehetővé teszi, hogy Erdoğan minél inkább a maga kezében összpontosíthasson minél több hatalmat és háttérbe szorítsa pártbéli riválisait, befolyással bíró minisztereit, így minimalizálja a kritikus hangokat.

Recep Tayyip Erdoğan szerepe magában a parlamentáris rendszerről az elnöki rendszerre való áttérében sem elhanyagolható. 2003-ban ő volt az, aki Özal közel másfél évtizedes ötletét újra szóba hozta, habár tudjuk, hogy az 1990-es évek során is voltak olyan politikusok, így Alparslan Türkeş vagy éppen Necmettin Erbakan is, akik kacérkodtak a gondolattal. Ugyan Erdoğan már 2003-ban felvetette a gondolatot, az elnöki rendszer bevezetése csak 2012-ben lett az AK Parti hivatalos politikai célja. Egyes politikai elemzők felhívják a figyelmet arra, hogy mindez a mai török politikai helyzetben elsősorban a jobboldali konzervatív és nacionalista pártoknak és politikusoknak kedvez, azaz 2017-ben leginkább Erdoğan pozícióját erősíti úgy, hogy közben ehhez a nacionalista párt, a MHP elnöke, Devlet Bahçeli is komoly politikai támogatást nyújt. (TURAN, 2018, 44)

Recep Tayyip Erdoğan helyzetét tovább erösítette, hogy a 2016. július 15-i sikertelen puccskísérlet után sikeresen pozícionálta magát, mint a nemzet és a török állam megmentője. Ezt a politikai sikert személyes befolyásának maximális növelésére fordította, és elérte azt is, hogy a 2019 novemberére tervezett elnök- és parlamenti választásokat hozzák elöre, hiszen számára ez tűnt kedvezőnek tekintettel arra, hogy nagyjából népszerüsége csúcsán állt és a 2019 végéig tartó majdnem kétéves időszakban ebből a popularitásból vélhetően sokat veszíthetett 
volna. Az, hogy a voksolást 2018. június 24-re hozták előre, tehát egyedül azt szolgálta, hogy növekedjék Erdoğan és az AK Parti újraválasztásának esélye. (TURAN, 2018, 45)

Mivel a fent felsorolt változások érezhetően a jobboldali konzervatív és nacionalista köröknek kedvez, illetve személy szerint is szolgálja Recep Tayyip Erdoğan politikai érdekeit, a baloldali ellenzék, tehát a CHP és annak vezetője, Kemal Kılıçdaroğlu részéről pedig heves tiltakozást eredményezett. Az ellenzéki pártvezér kifogásolta, hogy az új rendszerben aránytalanul megnő az elnök politikai befolyása, kiiktatásra kerülnek az eddigi fékek és egyensúlyok, melyek keretek közé szorították a köztársasági elnököt. Azzal is érvelt, hogy az elnöki rendszerre való áttérés során ugyan leginkább az Amerikai Egyesült Államokat vették alapul az alkotmánymódosítás megszövegezői, ugyanakkor arra nem minden esetben figyeltek oda, hogy fennmaradjon a hatalmi ágak klasszikus, demokratikus szétválasztása. Az, hogy a végrehajtó hatalom egy ember kezében összpontosul, Kıllçdaroğlu szerint azzal is járhat, hogy Törökország az egyszemélyi vezetés felé mozdul el. Az elnöki kinevezési gyakorlat megteremtése a CHP elnöke szerint tovább gyengíti a már amúgy is keretek közé szorított nemzetgyülést, szorgalmazta, hogy a miniszterek személyének kiválasztásánál a képviselők több jogot kaphassanak. Az ellenzék vezére azt sem tekinti elégséges biztosítéknak, hogy 360 képviselő kezdeményezheti az elnök bíróság elé állítását, ha az súlyos jogsértést követett el, hiszen erről a végső döntést titkosan kell meghozni, és 400 képviselő támogató szavazata szükséges hozzá. (MARSZAŁEK-KAWA-BURAK, 2018, 102)

A Köztársasági Néppárt mellett kifogásait hangoztatta az ellenzék másik jelentős pártja, a kurdbarátnak is nevezett Népek Demokratikus Pártja (HDP) is. A HDP keményebb kritikát fogalmazott meg az alkotmánymódosítással kapcsolatban, mint a CHP, sőt, a népszavazás bojkottjára szólította fel szimpatizánsait. A CHP-hez hasonlóan a HDP is azzal érvelt, hogy a rendszer egyszemélyi hatalomkoncentrációhoz vezet. A HDP nem felejtette el megjegyezni, hogy ez az átmenet nem nevezhető legitimnek és demokratikusnak, amíg a pártjuk képviselőinek egy jó része börtönben ül. (MARSZAŁEK-KAWA-BURAK, 2018, 102)

$\mathrm{Az}$ elnöki rendszerre való áttérés ötlete eleinte a nemzetközi közvéleményt is aggodalommal töltötte el. Ugyanakkor ahogy közeledett a 2017-es népszavazás időpontja, úgy csendesedett el az Európai Unió kritikája Törökország és Recep Tayyip Erdoğan felé. A látványos hatalomkoncentráció ellenére való csendet azzal magyarázhatjuk, hogy bár Törökország továbbra is tagjelölt, egyre kisebb az esélye, hogy valóban taggá váljon az európai integrációban, hiszen úgy tűnik, hogy az nem szolgálja egyik fél érdekeit sem. Mindemellett Brüsszel abban érdekelt, hogy tovább müködjön a szervezet és Ankara által megkötött 
menekültügyi paktum, aminek fennmaradását veszélyeztethetné a túlzott kritika. (PAULSEYREK, 2017, 2)

Abban a folyamatban, mely során Erdoğan igyekezett háttérbe szorítani potenciális politikai riválisait, az elnök számára jól jött a 2014. decemberében kitört korrupciós botrány, melynek következtében 2015. január 20-án négy korábbi minisztert, köztük Muammer Gülert és Eğemen Bağıșt, eltávolítottak a közéletböl. A 2015-ös év során egyre több kritika célpontjává tett, az Európai Unió és Törökország közötti menekültügyi megállapodást 2016. márciusában tető alá hozó miniszterelnök, Ahmet Davutoğlu is egyre inkább elszigetelődött, egyrészt népszerütlen külpolitikája, másrészt és sokkal inkább kritikus hangvétele miatt április 29-én lemondatták, helyére az Erdoğanhoz lojális Binali Yıldırım került.

Ahmet Davutoğlu miniszterelnök nyíltan vállalta azt a véleményét, hogy nem támogatja az elnöki rendszer bevezetésének gondolatát. Sokan ezt az álláspontot úgy értelmezték, hogy a volt külügyminiszter Recep Tayyip Erdoğan személyével elégedetlen, sőt vele helyezkedik szembe. Egy másik felfogás szerint a Stratégiai mélység című könyv szerzője Törökországra úgy tekintett, mint egy olyan államra, mely köteles és kénytelen olyan esetekben is felelősséget vállalni, mely túlmutat önmaga jelentőségén, és a Közel-Keleten belül politikai és katonai feladatokkal ruházza fel. Egy ilyen kiemelt geopolitikai helyzetủ ország pedig nem teheti meg, hogy egyszemélyi vezetés alatt álljon, azaz Törökország esetében nem szerencsés az elnöki rendszer bevezetése a 2010-es évek során, mikor két szomszédos országban is polgárháború zajlik, és a terroristák Törökországot is fenyegetik. Más megfigyelök szerint is egyértelmü, hogy komoly véleménykülönbség adódott 2015-2016-ban Erdoğan és Davutoğlu között, de vannak olyanok is, akik megjegyzik, hogy ez csupán ideológiai nézeteltérés, a két politikus továbbra is jól tud együtt dolgozni, csupán egyesek a politikai elitben össze akarják ugrasztani a két vezetőt. Egy harmadik közkeletű vélekedés szerint a háttérben a két politikus együttműködött, és a kívülről látszódó konfliktusok ellenére úgy érdemes Erdoğanra tekinteni, mint aki gyakorlatban igyekszik megvalósítani Davutoğlu tudományos megalapozottságú téziseit. (BAYRAM, 2016)

Érdemes megjegyezni, hogy bár Davutoğlura úgy szokás tekinteni, mint aki elveti az elnöki rendszert tekintettel Törökország geostratégiai helyzetére, valójában maga is rugalmasan viszonyulva a kérdéshez az idő múlásával egyre megengedőbb álláspontra helyezkedett. Egy 2015. novemberi TV-beszédében már úgy érvelt, hogy ugyan nem szimpatizál a készülő államreformmal, de van olyan elnöki köztársasági szisztéma, amit el tudna fogadni. Gyakorlatilag Davutoğlu is belátta, hogy a parlamenti rendszer nem müködik jól, amire a 
nemzetgyülési választási rendszer módosításával lehet megfelelő választ találni. (KÜTAHYALI, 2015)

Egyes szemlélők szerint Davutoğlu nézetei nem voltak összeegyeztethetők az Erdoğan által felmutatott vízióval. Két rivális rendszerről beszélt a két vezető. Az előbbi egy, „a nép által választott, uralkodószerü elnökben” gondolkodott, míg az utóbbi olyan parlamentben, mely jobban képviseli a választópolgárok sokszínűségét. (YEŞILLADA, 2016, 19)

A fenti példák és vélekedések is jól mutatják, hogy bár voltak ideológiai és stratégiai különbség, ám ez egyrészt áthidalható lehetett volna, illetve a két politikust is aránylag könnyen ki lehetett volna békíteni. Az, hogy nem így történt, csak megerösíti azt a feltételezést, hogy Recep Tayyip Erdoğan Davutoğlu elmozdításával hatalomtechnikai döntést hozott, és igyekezett egy kritikus hangot, egy tehetséges politikai riválist eltávolítani a hatalomtól. Davutoğlunak akkor lett volna esélye a túlélésre politikai értelemben, ha képes lett volna maga mögé állítani több vezető politikust az AK Parti parlamenti frakciójából, és így felmutathatott volna egy liberális alternatívát az Erdoğan által kínált elnöki rendszerrel szemben. (YEŞİLADA, 2016, 25) Ehhez viszont a miniszterelnök nem rendelkezett elég politikai befolyással és megfelelő karizmával a nála sokkal erőteljesebb és jobban beágyazott köztársasági elnökkel szemben.

Bár egyértelműek voltak az ideológiai és stratégiai nézeteltérések Erdoğan és Davutoğlu között, a végső szakításhoz nem az vezetett, hogy a két fél miként vélekedik az elnöki rendszer bevezetéséről, hanem egy belső, az AK Parti vezetését érintő ügy kapcsán szünt meg a kölcsönös bizalom. Az AK Parti egyik vezető testülete, A Központi Döntéshozó és Kormányzó Testület (MKYK) 47 tagja titokban aláírásgyüjtésbe kezdett, hogy a testület kinevezési gyakorlata változzon meg, ez a jogkör kerüljön ki a pártelnökként is funkcionáló Davutoğlu kezéből. Ezt követően Ahmet Davutoğlu hosszan tárgyalt Recep Tayyip Erdoğannal, és végül jobbnak látta lemondani. Ezzel megnyílt az út Erdoğan további hatalomkoncentrációja és a hozzá hü politikusok helyzetbe hozása előtt.

Az egyik ilyen lojális vezető a már említett, és miniszterelnökké is kinevezett Binali Yıldırım volt. Yıldırım Davutoğluhoz képest is kevésbé karakteres, kevésbé karizmatikus politikus. Az elnöki rendszer bevezetéséhez kapcsolódó politikai vitákban háttérben maradt, a sajtóban kevésbé volt látható, mint néhány ellenzéki vagy éppen kritikus személy. A legnagyobb példányszámú napilap, a Hürriyet elemzése például azt mutatja, hogy a reform kommunikációja szempontjából releváns két hónapban az ellenzéki, ám a reformmal szimpatizáló nacionalisták elnöke, Devlet Bahçeli négy százalékponttal többet szólalt meg, mint maga a miniszterelnök. (ÇAKIR, 2017, 288) 
Bár Yıldırımre azt mondhatjuk, hogy jóval kevésbé volt karizmatikus, mint hivatali elődje, ugyanakkor előnyére vált, hogy kompromisszumkészebbnek mutatkozott. Az AK Parti-nak erre azért is szüksége volt, mert nem volt meg a kellő számú képviselője ahhoz, hogy a nemzetgyülésben elfogadják a reform tervezetét. Yıldırım ennek tudatában kezdeményezett tárgyalásokat a MHP-vel és Devlet Bahçelivel, aminek eredményeképpen sikerült meggyőznie az ellenzéki képviselök egy részét arról, hogy nemzeti érdek a politikai reform. A kompromisszumkényszer azonban egy ponton visszavonulásra kényszerítette az AK Parti-t és a miniszterelnököt. Tekintettel arra, hogy az ellenzéki MHP csak bizonyos módosításokat fogadott el, be kellett érniük azzal, hogy marad a puccsisták 1982-es alkotmánya, amit a politikai szükség szerint módosítanak, és az AK Parti kénytelen lemondani arról, hogy egy teljesen új alkotmánnyal álljon a nép elé. (KAYA, 2017, 43-44)

Az AK Parti narratívája szerint Yıldırım történelmi tettet vitt véghez, ugyanakkor saját politikai szerepkörét beszúkítette. Ő lett ezzel a lépéssel a Török Köztársaság utolsó miniszterelnöke, mivel alkotmánymódosítással megszünt ez a tisztség, és kénytelen volt beérni a TBMM elnöki székével.

A július 15-i sikertelen államcsíny után még több, Davutoğluéhoz hasonló, szinte váratlannak nevezhető lemondás vagy lemondatás történt. Ezek sorába illik 2017. szeptember 22-én Kadir Topbaş isztambuli föpolgármester távozása. Ö volt az AK Parti történetében az első városvezető, aki -a hivatalos verzió szerint- önként hagyta hátra hivatalát. Topbaş lemondása azért is meglepte a török közvéleményt, mert saját bevallása szerint nem volt konfliktusa az AK Parti felső vezetésével, nem lépett ki a pártból, maga után pedig egy jól müködő világvárost hagyott, mely egyáltalán nem halmozott fel adósságot szemben számos más önkormányzattal. (GEYVE MEDYA, 2017)

Azt mindenki elismeri, hogy Kadir Topbaşnak elévülhetetlen érdemei vannak a Boszporusz-parti metropolisz fejlesztésében. A szakmai szempontból sikeres városvezető bukásához -valószínűleg- a politikai riválisok sorozatos elmozdításán túl az is hozzájárult, hogy Topbaş közvetetten összefüggésbe hozható Fetullah Gülen mozgalmával, hiszen a vejét, Ömer Faruk Kavurmacıt, az Aydınlı tőkés csoport fejét letartóztatták a FETÖ-vel és a 2016. júliusi 15-i puccskísérlettel kapcsolatban. Kavurmacı érintettsége mellett azt hozták fel a nyomozók, hogy a házkutatás során az irodájából előkerült egy olyan plakett, amin szerepelt Fetullah Gülen aláírása. Az üzletember védelmében a török sajtó azt is megemlíti, hogy családjával együtt részt vett azon az ún. yenikapı nagygyülésen, amiről ebben a fejezetben még említés történik, és ami a nemzeti egységet volt hivatott előmozdítani. (HABER SOM, 2016) 
Alig több, mint egy hónap múlva, október 28-án, Erdoğan kérésére Melih Gökçek ankarai főpolgármester is távozásra kényszerül. Gökçekről és lemondásáról részben ugyanaz mondható el, mint isztambuli kollégájáról. Gökçek is sikeres, népszerü és innovatív városvezető volt, aki így riválisnak tekinthető, ugyanakkor közvetett kapcsolatba sem hozható a FETÖ-vel. Sőt, a sikertelen puccskísérlet éjszakáján a FETÖ tagjai az ankarai polgármester iránti ellenszenvük okán igyekeztek azt is elhitetni a lakossággal, hogy Gökçeket letartóztatták. (DEMİRÇAĞLAR, 2017, 36) Az a tény, hogy Gökçek nem nevezhető gülenistának, erősíti azt a feltételezést, hogy lemondása inkább kapcsolódik Erdoğan hatalomkoncentrációjához, mint más belpolitikai eseményekhez.

Az AK Parti-n belüli dezintegráció mellett nemzeti szinten integrációs folyamatokat figyelhetünk meg. A 2016. augusztus 7-én az isztanbuli Yenikapı-nál megrendezett tömeggyülés egy pódiumra gyüjtötte az elnök a török politikai erők vezetőit, és megágyazott az AK Parti és a nacionalista MHP közötti együttmüködésnek. Magán a demonstráción a szervezők szerint több millió ember jelent meg. (Miş et al., 2016, 9) A nagygyülés egyrészt képes volt a politikai szereplőket és a közvéleményt is meggyőzni a nemzeti egység meglétéről és annak fontosságáról, másrészt azt is megmutatta, hogy egy történelmi sorsforduló és tragédia után -ugyan csak rendkívül rövid időre- az ellenzék is odaállt Erdoğan és a kormány mellé. Fontos megjegyezni, hogy ugyan a CHP politikusait a demonstrációra meghívták, azon csak a konzervatívok nyomására vettek részt. A HDP-t ugyan nem hívták meg, de politikai kommunikációjukban egyértelművé tették, hogy elítélték a demokráciába való fegyveres beavatkozást, és a találkozó idejére félretették az ellenségeskedést. (MISS et al., 2016, 13) A valóban meglévő ellentétek, a széthúzás és a leszalámizás közepette az, ami a Yenikap1 kikötőben történt értékes leckével is szolgált Törökország és a nagyvilág számára. Ha más nem, a szónokok legalább szóban kiálltak az egység, az együttes cselekvés és a demokrácia mellett. (KANTAR, 2016, 191)

A yenikapı nagygyülésen megszülető együttmüködés kellett ahhoz, hogy az év december 10-én a két párt közös alkotmánymódosítási javaslattal álljon elő a nemzetgyülésben. A két párt javaslatát elfogadta a parlament, majd 2017. április 16-án igen szűk többséggel (51,41\%), ám magas részvételi arány mellett a szavazók is megerősítették.

Fontos ugyanakkor megjegyezni, hogy a népszavazás kérdése törést eredményezett a nacionalista táboron belül, és Meral Akşener vezetésével egy új jobbközép párt alakult, amit IYI pártnak, azaz Jó Pártnak neveztek el. Ez a formáció a 2018-as országgyűlési választásokon 9,96\%-át szerezte meg a voksoknak, ezzel a TBMM ötödik legnagyobb frakcióját alkothatta meg, mindemellett radikális változást a török pártstruktúrában a megjelenése nem jelentett, 
legfeljebb még jobban megosztotta az ellenzéket, amelyik így még gyengébb a hatalmát egyre inkább koncentráló AK Parti-val szemben. Az IYI Partival kapcsolatban a szakértők arra figyelmeztetnek, hogy még kialakulatlan mind a gondolkodásmódja, mind a programja, illetve nem lehet tudni, hogy a pártvezetőnek mekkora szerep jut a párt jövőjének alakításában. Az IYI-hez hasonló technokrata centrumpártok számára a legnagyobb kihívás ugyanis a tömegek meggyőzése. (DURAN, 2017, 26-27)

Az ellenzéki politikai erőtér jelentős átrendeződése, egyes ellenzéki csoportosulások megerősödése és az AK Parti relatív népszerüség-vesztése komoly bizonytalansági tényező a 2019. márciusi helyhatósági választások előtt. A közvélemény-kutatások a két nagyvárosban, Isztambulban és Ankarában, lényegében fej-fej mellett hozzák a két riválist, a kormánypárt és az egyesült ellenzék pártjainak jelöltjét, a választás kimenetele bizonytalan, a győztes személye szinte megjósolhatatlan. Ez a kétesélyesség legföképpen az AK Parti köreiben növeli az instabilitás érzését. A kormánypártiak körében újfent a HDP politikai aktivizálódása kelt feszültséget, és mindenek előtt az, hogy a kurdbarát párt több török nagyvárosban annak ellenére konzervatív összellenzéki jelölteket támogat, hogy egyébként inkább baloldali, liberális alapállású politikai formáció. Ahogy a HDP egy komolyabb veszélyt jelent a gazdasági nehézségek miatt is egyre inkább gyengélkedő AK Partira, úgy hosszú távon kihívást jelenthet az ellenzék vezető erejére, a CHP-re is, hiszen -föleg a nyugati megyékben- a HDP szavazatnövekedése a CHP-szimpatizánsok átszavazásával valósult meg a múltban és várhatóan ez a trend folytatódik idén is, ami akár a kemalisták részleges erodálódásához is vezethet. (SAHBAZ, 2019:45)

Az elnöki rendszer kiépítése és az azzal járó politikai átrendeződés gyökeresen alakította át a török politikai szcénát. A szisztéma átszabása és a rendkívüli hatalomkoncentráció Recep Tayyip Erdoğan számára soha nem látott lehetőséget biztosít, ám komoly felelősséggel is jár. Ha ezt a szinte teljhatalmat nem jól használja, népszerüsége erodálódhat, és a tekintélyes felépítmény maga alá temetheti az egyre inkább partnerek nélkül kormányzó elnököt.

\subsection{Az Erdoğan-Gülen-párharc és a 2016. július 15-i sikertelen puccskísérlet}

Az elnöki rendszerre való áttérés és Erdoğan hatalomkoncentrációja mellett a 2015 és 2018 közötti időszakban Törökországban a másik fontos eseménysor, a FETÖ felemelkedése és bukása volt. A 2016. július 15-i puccskísérlet és az azt megelőző időszak két erős karakter, Recep Tayyip Erdoğan és Fetullah Gülen hatalmi harcaként is felfogható. Közös bennük az, hogy mindkettő hatalmi ambíciói túlmutattak azon, amilyen lehetőségeik 2002-ben, az AK Parti 
hatalomra jutása idején voltak, és az is, hogy -opportunista módon- igyekeztek a másikat kihasználni saját hatalmi ambícióik kiteljesítése érdekében. Miután ezek az ambíciók egymást kizárták, óhatatlanul konfliktushoz vezettek, a sikertelen puccs pedig jó alkalom volt Erdoğan számára, hogy leszámolhasson riválisával és annak hálózatával építve arra, hogy egyrészt azt megelőző 14 évben létrehozta és összekovácsolta saját támogatóinak körét, másrészt pedig Gülen a kemalisták és a nacionalisták körében is népszerütlen. Hatalomstratégiai szempontból nézve azt mondhatjuk, hogy Erdoğan legfőbb politikai ellenfelének a kemalizmust és a kemalistákat tartja, akik ellen rugalmasan alakítható szövetségeket köt, amelyek ha tarthatatlanná válnak, akár puccshoz és fegyveres konfliktusokhoz is vezethetnek.

Fetullah Gülen mozgalmát nagyon különböző módon ítéli meg a török és a nemzetközi szakirodalom és eltérő vélekedések láttak napvilágot a sikertelen puccs előtt és után. A nemzetközi szakirodalom megközelítésére jellemző az, amit például Marcinkó Éva írásában találunk, és ami szerint Gülen egy pacifista-demokrata ideológiát kínált a török társadalom számára azzal a céllal, hogy sajátos oktatási rendszerén keresztül biztos tudással bíró és erkölcsös nemzedéket neveljenek fel. Azt még Marcinkó elismeri, hogy ezt az idealizált képet csak a vallási közösség, a Hizmet mintegy négymillió tagja látja csak ennyire ideálisnak, a mozgalom kritikusai Gülenéket szektaként értelmezik, a mozgalmat politikai célokkal ruházzák fel, és azzal vádolják, hogy a szélsőséges iszlám fundamentalizmus talaján állnak. (MARCINKÓ, 2018, 53)

Ha a Gülen-mozgalom lényegét és működését akarjuk megérteni, akkor érdemes eltekinteni attól, hogy a politikai iszlám esetében van egy ürügy, a vallás, és a szélsőséges iszlám fundamentalizmust politikai eszmerendszerként kell értelmezni. A társadalom iszlamizálása, az ún. iszlám ébredés és a vallásgyakorlat egyre látványosabb megélése a politikai iszlám kezében nem más, mint a politikai nyomásgyakorlás egy-egy megnyilvánulási formája. (AZERI, 2016, 472) Gülen mozgalma sem tér el az iszlamista trendektől csak az idő múlásával különböző célok érdekében, eltérő módszereket alkalmaz. Az elmúlt fél évszázad során az ellenségképét is rugalmasan változtatgatta. A Hizmet kezdeti korszakában, az 1960-as években Gülen a baloldaliakkal és a marxistákkal helyezkedett szembe, később már törökiszlám szintézis néven nyíltan a társadalom iszlamizálását tüzte ki célul. Ez a törekvés csak erősödött az 1980-as katonai puccs után, mikor is Gülen igyekezett embereit kulcspozíciókba juttatni mind a politikában, mind pedig az államigazgatás különböző területein. Ez a folyamat az AK Parti 2002-es hatalomra jutásával sem állt le, hiszen az AK Parti jól tudta Gülen embereit mozgósítani a kemalisták elleni „harcban”. Ennek a harcnak a lényege a régi elitek, a CHP-hez köthető addigi vezető réteg eltávolítása, illetve a hadsereg vezérkarának átalakítása volt. Gülen 
és az AK Parti partnerre lelt egymásban, hiszen az AK Parti el akarta mozdítani a régivágású tiszteket, a Hizmet pedig a saját embereit szerette volna a helyükre ültetni, hiszen az elmúlt évtizedekben komoly pozíciókat szereztek a tisztképzés terén, és nagyszámú lojális emberanyag állt a rendelkezésükre. A két csoport közötti ellentét 2013 után kezdett a külső szemlélő számára is egyértelművé válni. Más-más módon ítélték meg már a Gezi parki eseményeket, de a 2014. decemberi korrupciós vádak és letartóztatások kapcsán egyértelművé vált a politikai konfliktus és az Erdoğan és Gülen között húzódó frontvonal. (AZERI, 2016, 466)

Ha a gülenizmust mint önálló eszmerendszert tekintjük, akkor is egyértelmüvé válik, hogy nem az egyénileg megélt hiten alapszik, hanem a közösségi vallásgyakorláson, és ebből fakadóan társadalmi és politikai követelésekkel lép fel. Gülen azzal érvel, hogy a törökök többsége hívő muszlim, azonban az ország világi elitje ezt nem hajlandó tudomásul venni, ezzel a ténnyel ellentétesen cselekszik, így mind vallási, mind pedig politikai szempontból hibát követ el. Gülen azt is követeli, hogy az iszlámot fel kell szabadítani, annak meg kell jelennie a közösségi terekben is azután, hogy előjött a mecsetek és a lakások falai közül. Söt, azt fogalmazza meg, hogy az élet minden egyes mozzanatát az iszlámnak kéne kormányoznia. (JAGER, 2016, 7)

Az Erdoğan és a Gülen vezette egyesek által pietistának tartott, mások szerint a politikai iszlám programját valló mozgalom, a Hizmet közötti hatalmi harc eleinte gazdasági síkon látszott kibontakozni, ugyanis 2015. február 3-án a török állami pénzügyi felügyelet gyakorlatilag államosította a Bank Asyát, a gülenisták financiális hátterét biztosító egyik fontos pénzintézetet. A Bank Asya kettős célt szolgált a Hizmet rendszerében. A hétköznapi szinten a pénzintézet feladata volt a mozgalom anyagi hátterének a támogatása, a tagok pénzeszközeinek kezelése. Az össztársadalmi szinten azonban a Bank Asya azzal volt megbízva, hogy járuljon hozzá a török pénzügyi- és bankrendszer iszlamizálásához. Erre az egyik bizonyíték az, hogy azon a piacon, ahol sok szereplő mozgott és csak kevés kínált az iszlám jognak, a saríának megfelelő pénzügyi termékeket (a Bank Asyán kívül az Albaraka Türk, a Kuveyt Türk és a Türkiye Finans nevezhető iszlám banknak, a többi a nyugati financiális elvek talaján áll), a Bank Asya volt az első bank, mely ún. szukukot bocsátott ki. (BELGE-EGRESI, 2015, 12) A szukuk olyan igazolást jelöl, mely szerint egy adott pénzügyi tranzakció az iszlám előírásai szerint zajlott le.

A Bank Asya államosítása mögött egy külpolitikai és külgazdasági játszma is felsejlik, amiben a török állam a török érdekeket igyekezett képviselni. 2014-ben ugyanis a Goldman Sachs közvetítésével a Bank Asyát a Katari Iszlám Bank számára szerették volna értékesíteni. 
Ezzel szemben a török kormány inkább azt látta volna jónak, ha a gülenista bankot valamelyik török állami pénzintézet vásárolja fel. Ezt követően a török állami pénzügyi felügyelet megtiltotta a bank számára azt, hogy kölcsönöket nyújtson, illetve szoros megfigyelés alá helyezte azt. (BELGE-EGRESI, 2015, 17) A Bank Asya államosítása mellett a török kormányzatnak volt még egy másik érve is, és ezzel közvetlen kapcsolat világítható meg a bank és a Gülen mozgalom elleni harc között. A bankot az állam felszólította arra, hogy hozza nyilvánosságra privilegizált részvénytulajdonosainak nevét, gyakorlatilag azokét, akik a Hizmet vezető oligarchái lehettek. A bank erre nem volt hajlandó, mert féltette a félig titkos hálózat leleplezését. (YANIKKAYA-PABUÇCU, 2017, 50) A Bank Asya eladásának megakadályozása már ekkor is felvetette a politikai motivációt, a későbbi események fényében pedig egyértelmünek is látszik.

Október 26-án az ügyészség a gülenistákhoz kötődő egyik céghálózat felszámolásával folytatta ezt a folyamatot, az Koza-Ipek konszern és 22 másik vállalat élére állami csődbiztost neveztek ki. Bár a holding régebbi, mint maga a Gülen mozgalom, hiszen még 1948-ban alapították, idővel a Hizmet egyik legfontosabb gazdasági háttérszervévé nőtte ki magát. A Koza-Ipek cégcsoport szerteágazó tevékenységi körrel volt jellemezhető, hiszen voltak érdekeltségeik a bányászatban, a könyvnyomtatásban és a médiában is. A csoport elleni támadás szeptember elsején indult meg, ekkor a török rendőrség egységei házkutatást tartottak a vállalat telephelyein, majd kineveztek egy felügyelőbizottságot, mely a Koza-Ipek tranzakcióit volt hivatott megvizsgálni. Az ő javaslatukra is döntöttek úgy a hatóságok, hogy a gülenista pénzügyi háttérszervezetet jobb megszüntetni, mint korlátozni. (HOLTON-LOPEZ, 2015, 71) Két napra rá két, a cégcsoporthoz kötődő TV-adó, a Bugün TV és a Kanaltürk volt kénytelen beszüntetni az adását. Ezzel megkezdődött a gülenista média felszámolásának folyamata is. 2016-ban hasonló sorsa jut a Zaman, a Gülen-hálózat legismertebb napilapja. A Hizmet ekkor még elég erősnek érzi magát ahhoz, hogy március 5-én és 6-án tömegeket vigyen ki az utcára. A demonstráció erőszakossá vált, Gülen híveit csak könnygázzal tudta feloszlatni a rendőrség.

A gülenista médiaportfólióhoz tartozó egyes orgánumok, így például az elsősorban a vallásos törököknek szóló Zaman újság, és a világ muszlimjait célzó angol kiadása, a Today’s Zaman is a güleni értelemben vett politikai iszlamizáció szolgálatában álltak. A Zaman a maga idejében Törökország legnagyobb előfizetői hálózatát tudta kiépíteni, a Hizmet tagjain túl minden nap eljutott a gülenista iskolákba (az ún. dershanékba) és a kollégiumokba, így a mozgalom fiatal tagjainak (át)nevelését is célozta. Mindemellett nagyon komoly bevételt is 
generált, a Gülen mozgalom egyik vezető pénzügyi biztosítéka is volt a média ezen szegmense. (DEMİR-ÇAĞLAR, 2017, 21)

A gülenista médiaplatformok sorozatos betiltását egyesek a szólásszabadság korlátozásaként élték meg, Erdoğan és az AK Parti hívei viszont úgy tekintettek erre lépésre, hogy ez egyrészt tovább gyengíti a Hizmet pénzügyi hátterét, másrészt viszont leszűkíti a kemalisták és a liberálisok mozgásterét is. A Fetullah Gülenhez köthető TV-csatornák, így a Samanyolu, a Bugün vagy a Can Erzincan rendszeresen helyet adtak a kormánykritikának, ám az sokszor nem lépett túl a meddő személyeskedésen, Erdoğan személyének támadásán, a konstruktív ellenzékiség helyett arról szóltak az adások, hogy a kormány miért képtelen bármit is megoldani. (DEMIR-ÇAĞLAR, 2017, 11)

Az Ipek Médiacsoporthoz tartozó termékek nem csupán teret adtak a kemalista és liberális hangoknak, de jellemzően a vallását nem gyakorló és nem is túl konzervatív rétegeknek szóló tartalmakat publikált. Ezek az orgánumok 2013 előtt nagy szolgálatot tettek az AK Parti-nak annak érdekében, hogy könnyebben elérhesse ezeket a társadalmi rétegeket. Azzal, hogy 2013tól egyre inkább kormánykritikus hangot ütöttek meg, az AK Parti elvesztette egyik fontos csatornáját az ellenzék elleni küzdelemben, és a Gülenhez való kötődésen túl ezt sem tudtak megbocsátani az Ipek Holdinghoz kötődő újságíróknak, akik a nagy betiltási hullám után még megpróbálkoztak egy új újság indításával, ezt 2015. november 17-tôl kezdve Özgür Düşünce (Szabad gondolat) címmel lehetett rövid ideig még megtalálni az újságárusoknál. (DEMİRÇAĞLAR, 2017, 23)

A gülenista mozgalom folyamatos korlátozása vezet el az állam szövetébe beépülő hálózattal való teljes leszámoláshoz. A török kormány hivatalos magyarázata szerint ugyanis a 2016. július 15-i puccskísérlet mögött egyértelműen az önkéntes amerikai száműzetésben élő Fetullah Gülen és mozgalma állt. A sajtóban már 2016. áprilisában megjelentek olyan hangok, mely szerint a gülenisták puccsra készülnek a demokratikusan megválasztott kormány ellen. Fuat Uğur kormánypárti publicista értekezése szerint nem csupán várható egy ilyen csapás, de arról a török állam vezetése is tud, arra fel vannak készülve. (TAŞ, 2018.a, 1) A kormány szerint erre utalnak azok a titkos vallomások is, melyeket 2016 második felében rögzítettek, és melyek szerint az államcsíny szervezése már 2015. november 26-án megkezdődhetett, mikor is a Gülen mozgalom vezető imámjai egy titkos országos gyűlést tartottak, és a júliusi puccs részleteiről döntést is hoztak. (DURAN-AKGÜN-YÜCEL, 2017, 35)

A törökök által „leghosszabb éjszakának” nevezett 2016. július 15-én a Török Fegyveres Erők egyes alakulatai támadást intéztek egyes intézmények, és azokon keresztül a demokratikus berendezkedés ellen. Az eseménysor azzal kezdődött, hogy lázadó tisztek egy csoportja 22 óra 
táján ellenőrzésük alá vonta a hadsereg föparancsnokságát. Ezzel egyidőben más fegyveres csoportok megszállták a közmédia, a TRT épületeit Ankarában, illetve felvonultak Isztambul legfontosabb hidjára, ahol később sortüzet is nyitottak az rövid időn belül megjelenő civil tiltakozókra, akik közül többeket is halálos sebesülés ért. Az addig Boszporusz hídként ismert építményt azóta Július 15. mártírjai hídra nevezték át. Ezt követően, 23 óra 24 perckor egy jelentős robbanás következett be a rendőri elitalakulatok az Ankara megyei Gölbaşıban található kiképzőközpontjában, itt mintegy 60 rendőr vesztette életét. Ezzel nagyjából egyidőben a puccsisták túszul ejtették Hulusi Akart, a hadsereg főparancsnokát. Éjfél után pár perccel Ankarában helikopterekkel kezdték el bombázni a MIT, azaz a török titkosszolgálat központját, ezt követően hasonló támadás érte az új elnöki palotát és a Nagy Török Nemzetgyülés épületét is. Mikor a lázadó tisztek úgy érezték, hogy kézre kerítették a stratégiai szempontból legfontosabb létesítményeket, az állami tévében nyilatkozatot olvastattak be egy riadt bemondónővel arról, hogy átvették a hatalmat. Erre válaszul Recep Tayyip Erdoğan köztársasági elnök, mivel menekülnie kellett arról a tengerparti üdülőhelyről, ahol a puccsisták megtámadták a szállodát, ahol tartózkodott, és másképp nem tudott a néphez szólni, egy okostelefonos felvétel segítségével jelentkezett, amit a CNN Türk adásában játszottak le. Ebben a nyilatkozatban az elnök arra kérte a törököket, hogy vonuljanak ki az utcára és védjék meg a demokrácia értékeit és a török államiságot. Mivel a fegyveres erők nagy része hü maradt a kormányhoz, hajnali kettő óra körül megindult az ellencsapás és megkezdődött az elkövetők örizetbe vétele. A sikertelen puccsnak hivatalosan 250 halálos áldozata volt, akiket a török közvélemény şehitként, azaz mártírként tart nyilván. (ANADOLU AJANSI, 2016, 8-12) Törökország történetében július 15-én a kormányt megdönteni szándékozók azért nem jártak sikerrel, mert mind a katonaság, mind pedig a nép körében nem rendelkeztek kellő támogatottsággal.

Már a puccskísérlet idején, még mikor a lázadó katonai egységek kint voltak az utcákon, a török és a nemzetközi sajtó is azt kutatta, kik a felelősök, kik is állnak valójában az elvetélt államcsíny mögött. Számos spekuláció látott szinte azonnal napvilágot kezdve attól, hogy a CIA áll az események mögött, vagy Fetullah Gülen összefogva a CIA-val, de voltak olyanok is, akik arra gyanakodtak, hogy Erdoğan saját magát próbálta megdönteni. (KOENIG, 2016) Recep Tayyip Erdoğan köztársasági elnök hezitálás nélkül egykori szövetségeséből lett fő riválisára, Fetullah Gülenre mutatott. Eszerint az értelmezés szerint Gülen már évekkel azelőtt létrehozott egy hálózatot, mely célja az állam aláásása volt úgy, hogy létrehoz egy párhuzamos állami szerkezetet. Ezt a kormány állítása szerint alátámasztja az a több tízezer vallomás, amit a puccsot követő napokban gyüjtöttek össze mindazoktól, akik Gülen mozgalmához tartoztak a 
legmagasabb rangú tisztektől kezdve az egyszerü baklavakészítőkig. A közérthetőség kedvéért a kormányoldal erre a szervezkedésre a Fetullahista Terrorszervezet (FETÖ) elnevezést kezdte használni. (TAŞ, 2018, 5)

2016. július 20-án a puccskísérletet követően rendkívüli állapotot (török rövidítése: OHAL) hirdettek ki Törökországban, ami másnaptól lépett érvénybe, és eredetileg három hónapig szándékozták fenntartani, ám azt többször is meghosszabbították. Az OHAL kihirdetése mellett Recep Tayyip Erdoğan egy önkorlátozó nyilatkozatot is tett, ami szerint ezt a helyzetet nem politikai ellenfeleivel való további leszámolásra fogja használni, hanem csak arra, hogy stabilizálja az országot a katonai államcsínykísérletet követően. Az OHAL eredeti küldetése szerint a jogállam, a szabadságjogok és a demokrácia időleges korlátozása mindaddig, amíg nem sikerül a puccs mögött található bünszervezetet teljesen megszüntetni. (YİĞİTER, 2016, 478)

Rövid időn belül 40 ezer fönél is többet tartóztattak le, közül 150.000 embert vontak valamilyen intézkedés alá, őket azzal vádolták meg, hogy a FETÖ tagjai és támogatták a lázadó fegyvereseket. A 667. számú elnöki rendelet segítségével a FETÖ-höz köthető összes szervezetet, iskolákat, kollégiumokat, média- és egyéb vállalkozásokat, egyesületeket és alapítványok egész hosszú sorát tiltotta be az OHAL adta eszközökkel élő hatalom. A FETÖ felszámolását célzó folyamat jól megmutatta, hogy az egykor négymilliós becsült gülenista közösség milyen jól beépült az élet minden területére, és mindenhol igyekeztek a kulcspozíciókat megszerezni. A FETÖ megszüntetése éppen a számos szektort érintő, nagyszámú letartóztatással és állásvesztéssel járó akciói miatt az AK Parti kritikusai szerint a civil szféra, az egyetemi autonómia vagy éppen a sajtószabadság korlátozásaként értelmezhető. Egyesek egészen odáig mennek, hogy azt állítják, paranoia lett úrrá a török társadalmon. (SLOAT, 2018, 4)

Ha megnézzük, hogy a nagy számú letartóztatás és állásvesztés mögött valójában paranoia, leszámolás vagy a FETÖ elleni intézkedés áll-e, akkor azt találjuk, hogy a legtöbb letartóztatott, illetve állásából elmozdított ember egészen a puccskísérlet napjáig aktív kapcsolatot ápolt a Gülen mozgalommal. Az egyetemi szférában például három hullámban összesen 4.500 oktatót érintettek a FETÖ elleni lépések. A 686-os számú törvényerejü elnöki rendelet, az első olyan, ami ebben a témában született összesen 330 egyetemi tanárt fosztott meg a katedrájától. A 330 érintett személyből 147 aláírta azt a két nyilatkozatot, az „Akadémikusok a békéért” és az „Ebben a bünben nem leszek tettestárs” címűeket, amelyeket nem sokkal július 15. előtt gülenista értelmiségiek jegyeztek. (ATEŞ-AKPINAR, 2017, 2) 
A puccsisták nem voltak képesek maguk mögé állítani a fegyveres erők többségét. Az államcsíny sikertelenségéhez ezen kívül nagyban hozzájárult a népi ellenállás. Az, hogy Erdoğan hívására valóban milliók mentek le az utcákra július 15-e éjszakáján, és hogy az azt követő napokban és hetekben is millióan vettek részt az ún. demokrácia virrasztásokon, tovább erősítette a kormányoldalt és gyengítette a gülenistákat. A későbbi puccsok megakadályozása érdekében számos adminisztratív intézkedést is hoztak. Ezek közül talán a legfontosabb a tisztképzés rendszerének átható reformja, ami meggátolhatja azt, hogy a felnövekvő katonai nemzedék szembe forduljon a török állammal.

A július 15-i puccskísérlett sokk és trauma volt a török nép számára, de lehetőséget is adott nekik arra, hogy átgondolják azt, amit a török demokráciáról vallanak, és kiálljanak e sajátosan anatóliai demokráciamodell mellett. A puccs tragédiája összekapcsolódott a demokrácia védelmének hősiességével, 2017-ben ezen a napon már egy új nemzeti ünnepet ülhetett meg a török nemzet.

\subsection{Törökország belső biztonsági helyzetének megrendülése}

Az elnöki rendszerre való áttérés és az Erdoğan-Gülen párharc mellett, ám azokkal szoros összefüggésben több esetben megrendült Törökország belső biztonsági helyzete. Hosszabb békésebb időszak után, 2015. április 11-én újultak ki a harcok a kormánycsapatok és a PKK között. Az év augusztus hónapjától kezdve felélénkültek a PKK támadásai. 2015 és 2016 augusztusa között összesen 488 terrorakciót hajtottak végre civil és katonai célpontok ellen, 35 esetben autóba rejtett pokolgépet hoztak müködésbe. (ÖZÇELİK, 2016, 10)

A PKK aktivizálódása a kurdbarát Népek Demokratikus Pártjának (HDP) politikai megközelítéséből fakad. A HDP azon túl, hogy klasszikus etnicista nacionalista követeléseket fogalmaz meg, a kurd nyitás politikájának hasznát kihasználva Erdoğan ellenzéke kívánt lenni, semmiben nem akartak megalkudni a kormányzattal és teljesen hiányzott belölük a kompromisszumkészség. Ha a HDP politikája, mely motivációul szolgált a PKK számára, nacionalista volt, akkor Erdoğan válasza is annak nevezhető, hiszen a török állam és nemzet egysége nevében, az egyetlen zászló, egyetlen haza és egyetlen nemzet pántörök nacionalista elv mentén, az erő nyelvén válaszolt. A két nacionalizmus összecsapása nem korlátozódott a hegyekre, a HDP városi rendezvényeit és pártirodáit is számos terrortámadás érte. Ezek nyitánya az a robbantás volt, mely 2015. június 5-én 3 embert megölt és mintegy 100-at megsebesített Diyarbakırban, az ország történetének legtragikusabb támadására ugyanazon év október 10-én került sor Ankarában, ott 103 volt a halálos áldozatok száma. Ezt az utóbbi 
támadást az Iszlám Állam (IÁ) terrorszervezet öngyilkos merénylői követték el, akik egymástól mintegy húsz méterre helyezkedtek a tömegben és egymás után hozták müködésbe a testükre erősített robbanószerkezeteket. Az Iszlám Állam tudatosan választotta ki a célpontot, hiszen nem csupán abban lehetett biztos, hogy hatalmas pusztítást okoz, de abban, is hogy a már amúgy is megosztott török társadalomban újabb frontvonalakat képez, tovább élesíti a központi kormányzat és a kurdok közötti feszültséget. Az ország többszintü megosztottságára példa, hogy a török hatóságok végül az ún. Dokumacı-hálózatot vádolták meg. Az IÁ-hoz köthető fegyveres sejt tagjai maguk is kurd nemzetiségüek voltak, a török-szír határ mentén fekvő Adıyaman városából származtak, ahol egy teázóban ismerkedtek meg szalafista nézetekkel, majd radikalizálódtak. (GÜRCAN, 2015, 27)

A bombák ugyanakkor nem voltak képesek a HDP-t megtörni, a párt kétszer is átlépte a magas, $10 \%$-os bejutási küszöböt, és a török nemzetgyülésben frakciót alapíthatott. A HDP magas választási eredménye proxy indikátornak tekinthető abban az értelemben, hogy ha valóban feltételezhető a PKK-HDP összefonódás, akkor ezek a voksok a PKK melletti kiállásként is értelmezhetők. Sőt, azt is megmutatják, hogy a PKK társadalmi támogatottsága nem korlátozódik a délkeleti országrészre, a szimpatizánsok minden megyében megtalálhatók. (BEZCİ-BORROZ, 2015, 2)

A választások után az AK Parti képtelen volt önállóan kormányt alakítani, a HDP minden eszközzel blokkolta a folyamatot, ami a harcok kiújulásával járt Délkelet-Törökországban. A kurdok elleni erőteljes fellépés növelte az AK Parti népszerüségét, miközben a HDP is képes volt megőrizni a maga szavazótáborát, így a 2015 őszén megtartott újabb választást már abszolút többséggel nyerte az AK Parti, következésképpen a HDP elvesztette annak esélyét, hogy az ellenzékből nyomást gyakoroljon. 2016. november 4-én a HDP vezetőit, köztük Selahattin Demirtaşt is letartóztatták. Erdoğan így újabb esélyt kapott a hatalomkoncentráció folytatására és az elnöki rendszer bevezetésére. Mindez annak az eredménye, hogy a HDP nem volt képes élni a helyzettel és konstruktív ellenzékiként viselkedni, hiszen Erdoğan eleinte valóban arra számított, hogy Demirtaş és a HDP támogatni fogja az első részben bemutatott, elnöki köztársasági rendszerre való áttérés folyamatát. Az elnöki várakozásokkal szemben a karizmatikus kurd vezető provokatív módon lépett fel, elutasította Erdoğan közeledését, aki hatalma megszilárdítása érdekében nem gátolta meg, hogy a HDP társelnökét és további 11 vezető politikusát börtönbe csukják. (PÉNZVÁLTÓ, 2016, 5)

A belbiztonsági helyzet romlására egyre több iszlamista támadást is fel lehet hozni példaként. Ezek közül az egyik legelső 2016. január 12-én következett be Isztambulban a Kék Mecset előtti téren. A merényletben 12 német állampolgár vesztette életét, ami tovább terhelte 
az amúgy sem túl jó török-német viszonyt. A sok támadás között talán az sokkolta leginkább a török közvéleményt, mely augusztus 20-án Gaziantep városában történt, ahol 56 fö, köztük számos kisgyermek halt meg egy leánybúcsúban. A nemzetközi közösség számára pedig a legemlékezetesebb az a támadás lehetett, melyet az Iszlám Állam terroristája újév ünnepén az isztambuli Reina mulató ellen intézett, ahol 39 különböző állampolgárságú ember esett áldozatul. A Boszporusz partján fekvő nagyon elegáns szórakozóhely elleni támadás, amit egyetlen egy fegyveres, az üzbég származású Abdulkadir Masaripov követett el, jól megmutatta, hogy a folyamatos biztonsági óvintézkedések ellenére is elég védtelen Törökország az iszlamista terrorral szemben annak ellenére, hogy az IÁ terrorszervezet feje, Baghdadi éppen két hónappal tette nyilvánossá azon nézeteit, hogy egészfrontos támadásra készül Törökország ellen. Baghdadi egyértelművé tette, hogy mindezt bosszúnak szánja azért, mert Törökország beavatkozott a szír polgárháborúba és bevonult az arab ország északi részére. (YAYLA, 2017, 9)

A folyamatosan romló biztonsági helyzet és a puccskísérlet utóhatásai ellenére Törökországban 2018-ban lezajlott az elnöki rendszerre való áttérés, és a 2018. június 24-én megrendezett általános- és köztársasági elnöki választások eredményeképpen befejeződött az elnöki rendszerre való átmenet folyamata. Az elnök kezében olyan hatalom koncentrálódik, mely segítségével kemény kézzel vezetheti a köztársaságot, és könnyen meghatározhatja az ország, és azon belül politikai ellenfelei jövőjét, saját embereit pedig kulcspozíciókba ültetheti. Így lett Binali Yıldırımből a parlament elnöke, Yaşar Gülerből pedig a hadsereg főparancsnoka. Erdoğan hatalomkoncentrációjához és az elnöki szisztéma kiépüléséhez a kormányoldal egységességén túl az is hozzájárult, hogy az ellenzék szétaprózódott és képtelen volt egy olyan hiteles elnökjelöltet találni, aki mindkét politikai oldal számára elfogadható. (MISŞ-DURAN, 2018, 28)

\section{Következtetés}

\subsection{Az előfeltevés visszaigazolása}

A Török Köztársaság története két egymástól jól elkülöníthető részre osztható: az egypárti és a többpárti időszakra. Amíg az egypárti időszak a kemalista elvek mentén szerveződő egyfajta egyeduralom volt, ami természeténél fogva törekedett a stabilitás megteremtésére, addig az 1946-ban bevezetett, és az 1950-es választásokkal megerősített többpártrendszer már nem minden esetben volt képes a politikai és gazdasági bizonytalansági tényezöket kiküszöbölni. 
Több olyan eseményt is tudunk említeni, illetve elemeztünk jelen írásunkban, amelyek a stabilitás ellen hatottak, illetve a stabilitás hiányából fakadó reakcióként értelmezhetőek.

A stabilitás ellen hatott a török politikai életben a 2000-es éveket leszámítva fennálló koalíciós kényszer. A legjobb példa a többpárti kormányzás sikertelenségére az 1990-es évek, és főleg annak második fele, mikor is nagyon különböző színezetủ politikai pártok álltak össze, de a politikai programjukkal, a mindennapi politizálás során nem tudták a kormányzati stabilitást biztosítani egy évnél hosszabb ideig. Sőt, 1997-ben még a hadsereg is beavatkozott a pártpolitikai csatározásokba azzal, hogy a rákényszerítette az ún. „posztmodern” puccs során a Necmettin Erbakan vezette, iszlamista gyökerünek mondott Refah pártot arra, hogy hagyja el a kormányt. Ez az eset rávilágít a stabilitás hiányából fakadó legjellemzőbb reakcióra is, nevezetesen arra, hogy a magát a szekuláris, köztársasági hagyományok letéteményesének és örzőjének tartó Török Fegyveres Erők egyre csökkenő intenzitással ugyan, de még az elmúlt két évtizedben is beleszóltak a politikai élet alakulásába. A honvédség a köztársaság többpárti időszakában három puccsot is levezényelt, háromszor is erőnek erejével vette át a hatalmat, ezzel ugyan stabilizálta az országot, de megakasztotta annak demokratikus fejlődését. Érdekes paradoxon, hogy a szekuláris, nyugatias értékek védelmezőjének képében feltünő hadsereg beavatkoztatásai rombolták a demokratikus ethoszt, az intézményi stabilitást. A hadsereg láthatóan nem a megoldás, hanem mindinkább a probléma része lett.

A fent leírtakból két társadalmi jelenség fakadt. Egyrészt a folytonos koalíciós csatározások, a különböző politikai és társadalmi érdekek ütközése negatívan hatott a török gazdaságra, vágtató inflációt okozott, illetve burjánzóvá tette az ilyen válságos időszakokra szinte mindig jellemző korrupciót. Másrészt a hadsereg túlhatalma egyre nyomasztóbban hatott a NATO-tag és az Európai Unióba igyekvő Törökországban, és elengedhetetlenné vált a török társadalom demilitarizálása.

A koalíciós időszak 2002-ben ért véget. Bülent Ecevit kormánya lényegében megbukott: nem volt képes társadalmi feszültségek nélkül kezelni az országot sújtó természeti és gazdasági katasztrófát. Az 1999-es év mindkét szempontból tragikus volt. Nyugat-Törökországot pusztító erejü földrengés tette a földdel egyenlővé, a török líra árfolyama pedig elérte mélypontját, eddig nem látott mértéket öltött a vállalkozói szféra csődje, nőtt a munkanélküliség. A kormány erre a Nyugatról átvett recepttel, a neoliberális gazdaságpolitikával és a megszorító intézkedésekkel válaszolt.

A török választók többsége 2002-ben úgy döntött, hogy az ország stabilitása a pártpolitikai érdekek felett áll, és teljes szemléletváltásra voksoltak. Ez a szemléletváltás a török politikai élet három klasszikus oldala (kemalista-baloldali, nemzeti és konzervatív) közül a vallási 
értékek mentén politizáló konzervatívoknak sikerült a legjobban, legalábbis ez volt az az oldal, mely leginkább ezt a képet tudta sugározni magáról a néptömegek felé. A néptömegek elvárásai - mint azt a bevezetőben Sartori elmélete alapján kifejtettük - több szinten is hatással vannak a politika szereplőinek döntéseire. Ezért nem meglepő, hogy a konzervatívok új pártot hoztak létre. Ez a párt, a vizsgálódásunk tárgyát is képező Igazságosság és Fejlődés Pártja (AK Parti) meg tudta győzni a szavazók széles tömegeit arról, hogy tényleg korszerü, az eddig is ismert politikusokat a sorai között tudó formáció, amely tényleg megújult, valóban felveszi a harcot a korrupcióval, rendbe teszi a gazdaságot és a hadsereget visszatereli a laktanyákba. Emellett, az AK Parti a török nemzeti identitás újradefiniálásával, a nacionalizmus eszköztárával is mozgósítani tudott.

A választói preferenciák és a mobilizációs eszközök mellett az intézményi struktúra is az AK Partinak kedvezett. A török választási rendszer sajátossága, a magas (10\%-os) bejutási küszöb. Ennek betudhatóan az AK Parti bár nem szerezte meg a voksok abszolút többségét, mégis képes volt önállóan kormányt alakítani. A két rákövetkező választás során pedig még tovább tudta növelni szavazatainak számát és arányát, és ezzel a török történelemben létrejött egy olyan „hosszú évtized”, amelynek során egy adott politikai erő a saját elvei alapján újjászervezte a társadalmat, és helyzetbe hozta a középosztályt, valamint jelentős gazdasági és szociális reformokat vitt véghez, és végül, de nem utolsósorban látványosan felfejlesztette az ország infrastruktúráját.

A 2002-ben hatalomra jutó konzervatívok határozott tervekkel láttak hozzá a török társadalom és intézményrendszer lassú, ám gyökeres átalakításához, ami nyugodtan nevezhető felülről irányított modernizációnak is. Az AK Parti választási- és kormányprogramjaiból egyértelmủ állam- és demokráciaeszmény bontakozik ki, és ellentmondást nem türően ezt a ideált követve politizáltak a vizsgált időszak teljes ideje alatt úgy, hogy az első évtizedben ez egyfajta nyitásként fogható fel, míg 2013-tól kezdve minél inkább bezárkózásként írható le. Ez a megközelítás amúgy nem idegen a török néplélektől és a török politikai fejlődéstől, hiszen a köztársaság megalakítása után maga Mustafa Kemal Atatürk is ezzel az eszközzel élt. Sőt, talán rá ez még hatványozottabban is igaz volt.

Az AK Parti kormányák felülről irányított reformjai abba az irányba is hatottak, hogy csökkentek a területi különbségek, illetve a szociális szakadék a fejlett nyugati és az elmaradott keleti területek között. Az infrastruktúra fejlesztése a nyugat-törökországi városok arculatát is átszabta. Isztambul, Ankara vagy épp Bursa egyre inkább az európai nagyvárosokra kezdett hasonlítani. A csillogás, a gyors átalakulás azonban sokaknak nehezen volt követhető, és ez a területfejlesztési hév volt az is, ami az AK Parti-kormányzás árnyoldalait is felszínre hozta. 
2013-ban az isztambuli belvárosban található Gezi park átalakítása robbantotta ki azt az elégedetlenségi hullámot, amely eleinte a zöld mozgalmak követeléseit hangoztatta és békés jellegü volt, de később erőszakossá vált, és egy nyugatias, liberális alternatíva keresése irányába mutatott, amelyben szerepet játszott számos szélsőbaloldali elem is.

A Gezi parki tiltakozás és az azt követő rendbontásokkal kísért események kétségkívül a válság legmarkánsabb jelei voltak, ám nem állíthatjuk, hogy a Gezi parkiak voltak az egyetlen csoport, mely az AK Parti elmozdítását célozta a hatalomból. Az AK Parti legfőbb ellenfelei közé sorolhatjuk egyrészt a régi kemalista elitet, másrészt azokat a katonai és civil csoportosulásokat, melyeket a kormánypárt összeesküvéssel vádolt meg. A 2002-ben a hatalomból eltávolított kemalista elit több fronton is támadta az AK Partit. Az egyik ilyen próbálkozás a párt betiltására irányult és az alkotmánybíróságot is eszközül használta. Ez a támadás azon bukott el, hogy az AK Parti hitelt érdemlően tudta bizonyítani, hogy elődpártjaitól eltérő módon - bár vallási eredetü értékeket is vall - szekuláris módon müködik, nem áll szemben a demokratikus és a köztársasági értékekkel. A régi kemalista elit másik próbálkozása a számos katonai hátterü összeesküvésben érhető tetten. Ezek közül a legnagyobb visszhangot az Ergenekon-ügy váltotta ki. Ez az ultranacionalista csoport több gyilkosság és terrortámadás hátterében állhatott, állítólagos vezetőjét, a valamikori vezérkari főnököt, İlker Başbuğ-t egy időre rács mögé is juttatták, de a hosszú pereskedés csak azt bizonyította, hogy a katonaság egyre kevésbé képes bármely polgári kormány megdöntésére. Végül is azt mondhatjuk, hogy manapság már nem a kormányok hüségesek a hadsereghez, hanem pont fordítva, a Török Fegyveres Erők a kormány politikai céljainak kiszolgálója, mint ahogy az a klasszikus demokráciákban is megszokott. „Az EU által kötelezően előírt reformoknak köszönhetően a hadsereg elvesztette azt a basáskodó hatalmát, amelyet minden egyes puccs után megerősödni látott, az ilyenkor szokásos memorandumaik és politikai kijelentéseik egyre kevésbé jelentősek azért, mert erodálódott a szavahihetőségük az Ergenekon-, a Balyoz- és az 1980-as és 1997-es puccsokat lezáró perek kapcsán. Ezek a perek megerősítették a török demokráciát, és egyre lehetetlenebbé tették azt, hogy a katonaság megdöntse a nép által választott kormányt.” (AKNUR, 2013, 146-147)

A kormány stabilitását talán leginkább próbára tevő konfliktus nem a látványos zavargásokkal járó Gezi parki események kapcsán vagy az Ergenekon-ügy folyományaként került a köztudatba, hanem akkor, amikor az AK Parti úgy döntött, hogy bezáratja az egyetemi felvételi előkészítő iskolákat. Ez a látszólag oktatáspolitikai döntés valójában a „belső ellenzékkel” való leszámolás első akkordja volt. Tudniillik a legtöbb ilyen előkészítő iskolát a Hizmet, az Amerikában élő hitszónok, Fethullah Gülen mozgalma müködtette. Gülen 
közösségét belső ellenzéknek neveztem, hiszen tagjai szavazataikkal sokáig az AK Partit támogatták, ám ez a csoport több belső ellenzéknél, hiszen külön politikai céllal bír, és ezért sajátos mozgalmi szervezkedési rendet hozott létre. A kormánypárti török média ezt, a közigazgatás számos posztját a saját kádereivel feltöltő rendszert „párhuzamos szervezkedés” címkével látja el. A Gülen-mozgalom ereje is épp ebben van. Azért képes még mindig dacolni az AK Partival, mert több évtizedes előkészület áll mögötte, és olyan tagokból tevődik össze, akik a végsőkig kitartanak a vezető mellett, aki tevékenységét isteni parancsként éli meg.

Ebből a felsorolásból is jól kitünik, hogy a háromszori választási győzelem, az abszolút többség és a választói felhatalmazás önmagában még nem elég ahhoz, hogy egy kormány stabilan vezethesse Törökországot 13 éven keresztül. Meggyőződésem, hogy ebben két olyan tényező is fontos szerepet játszik, amelyek közül az egyik köthető az AK Partihoz, a másik attól független. Az AK Partihoz köthető faktor az, hogy az AK Parti nem csupán programpárt, hanem saját társadalmi-gazdasági-politikai víziója van, nem csupán ideológiai párt, hanem abban hisz, hogy történelmi küldetése van a törökség számára. Ezt leginkább a Hedef 2023 (Cél 2023) víziója támasztja alá, mely szerint 2023-ra, a köztársaság kikiáltásának 100. évfordulójára Törökországból egy világhatalmi tényezőt kíván faragni. Ebböl a szemszögböl nézve a török belpolitikát az AK Parti egy olyan konzervatív párt, amely a progresszió oldalán állt hosszú ideig, támogatja az EU-csatlakozást és az európai értékrendet úgy, hogy abban ne vesszen el a törökség és az iszlám vallás világképe. A legnagyobb ellenzéki párt, a kemalista Köztársasági Néppárt viszont úgy tünik, hogy úgy határozza meg magát progresszívként, hogy közben egy régi hatalmi elitet és berendezkedést próbál konzerválni.

Az AK Partitól független faktor pedig az, hogy a új konfliktusok mögött álló „,új ellenzék” és a kemalista múltat bebetonozni szándékozó régi, parlamenti ellenzék nem képes hiteles alternatívát felmutatni. Ezt elsősorban az általunk új ellenzéknek nevezett csoportosulásoktól várnánk el. A Gezi parki tiltakozások rendszer-, AK Parti- és Erdoğan-ellenesek voltak, ám nem fogalmaztak meg egy olyan egységes eszmerendszert, amely tömegeket tudott volna megszólítani. Főleg nem tudott mit üzenni az AK Partiból esetleg kiábrándult, ám mérsékelt választóknak. Egy hatás viszont letagadhatatlan: a Gezi parki események a török ellenzékre irányították a Nyugat figyelmét, és a török ellenzék is felfigyelt a Nyugatra, mint potenciális támogatóra és ideológiai forrásra. Bár még mindig csak egy szűk városi értelmiségi réteget befolyásol ez a nyugatos liberalizmus, ez várhatóan az elkövetkezendő években terjedni fog, és Törökországban is kialakulhat egy, a nyugati államokhoz hasonló liberális kör, mely akár a mérleg nyelvét is jelentheti a parlamenti választásokon. 
A klasszikus ellenzék, azaz a CHP lehetőségei korlátozottak. Az elnökválasztás eredménye is megmutatta, hogy választóik nem tudják feltétlenül elfogadni azt, ha elvek nélkül összefognak az AK Parti ellen. A CHP egyre kevésbé képes tematizálni a közéletet. Az erre tett kísérletei kevéssé mobilizálják a saját szavazói bázist, és még kevésbé tudják megszólítani a konzervatív vagy nacionalista szavazókat.

Ahogy írtuk, az AK Partinak van egy sajátos nemzeti víziója és nincs egységes, és alternatívát felmutatni képes, erős ellenzéke. Ez már önmagában is esélyt adott nekik arra, hogy kitöltsék a mandátumukat a betiltási kísérlet, az e-memorandum, a Gezi parki zavargások és az összeesküvések ellenére is, ám még egy fontos tényezőre fel kell hívnunk a figyelmet. Mégpedig arra, hogy az AK Parti kellően kompromisszumkésznek is mutatkozott. A Gezi parki tiltakozások elején még merev volt a párt, Erdoğan pedig kvázi csőcseléknek nevezte a tüntetőket. Egy mintegy háromhetes bénultságot követően, pont mikor a demonstrációk természetrajzából fakadóan is alábbhagyott a tüntetések hevessége, az AK Parti utcára vitte saját híveit, és kiegyezett az elégedetlenek közül való mérsékeltekkel.

Fontos hangsúlyozni, hogy az AK Parti kormányzása során célszerü megkülönböztetni két korszakot. A két éra közötti cezúra a 2013-as év során következett be. Ekkor vált egyértelművé, hogy az addig folytatott demokratizálási politikát háttérbe szorítja egy komoly belpolitikai harc a később FETÖ-nek, Fetullahista Terrorszervezetnek nevezett Gülen Mozgalommal szemben. Bár a FETÖ már évtizedek óta igyekezett az embereit kulcspozíciókba juttatni az államigazgatás és a fegyveres erők keretei között, ekkor jutottak el arra a szintre, hogy erőteljes politikai, majd katonai lépésekkel megdöntsék a demokratikus államrendet, átvegyék a politikai hatalmat, a szekuláris Törökországból - Iránhoz hasonló módon - egy vallási ihletettségü államot építsenek. A FETÖ elleni fellépés nyitányaként az AK Parti-kormány úgy határozott, hogy a gülenistákat elvágja egyik legfőbb bevételi forrásuktól, és 2013. november 14-én arról határoznak, hogy betiltják az addig népszerü egyetemi felvételire felkészítő kurzusokat kínáló iskolákat, a dershanékat, melyek többségét a gülenisták üzemeltették, és ahol komoly tandíjat szedtek a diákoktól. A FETÖ erre szintén pénzügyi síkon próbált válaszolni. 2013. december 17-én és 25-én egyes, a gülenistákhoz köthetö ügyészek korrupciós vádakkal illettek számos, a kormányoldalhoz tartozó személyt, köztük három miniszter egyermekeit is. Az AK Parti és a gülenisták közötti harc a 2016. július 15-i puccskísérletben csúcsosodott ki. A 2013 és 2016 közötti nyílt harc és az azt követő kétéves rendkívüli állapot (OHAL, olağanüstü hal) miatt kényszerpályára került az AK Parti, fel kellett hagyniuk a demokratizálással úgy, hogy a török politikai rendszer radikális átalakításával felkészítsék a köztársaságot arra, hogy képes legyen magát megvédeni egy esetleges belső ellenséggel szemben. 
A kettős korszakolás abban a tekintetben is megállja a helyét, hogy az AK Parti és Recep Tayyip Erdoğan hatalomgyakorlási mechanizmusa is jelentősen megváltozott. A 2002-es hatalomrajutást követően a párt és kormány egy testvéri közösségnek tünt, ahol Erdoğan csak egyike volt a tehetséges és befolyásos politikusoknak. Az Erdoğan mellett az AK Parti és a kormány élén megjelenő markáns vezetők, így Abdullah Gül, Ahmet Davutoğlu, Bülent Arınç, Cemil Çiçek, Ali Babacan stb. fokozatosan háttérbe szorulnak, és az ország irányítása egyre inkább az egyszemélyi vezetés irányába mozdul el. Amíg több karizmatikus politikus alakította a török belpolitikát, addig Erdoğan is jobban rákényszerült arra, hogy velük egyeztessen, kompromisszumokat kössön.

A 2018-as elnökválasztás eredménye is azt mutatja, hogy Erdoğan továbbra is népszerü, népszerübb, mint saját pártja, győzelmével és a puccskísérlet utáni stabilizáció fokozatos befejezésével pedig esélyt kap arra, hogy visszatérjen a 2013 előtti demokratizáláshoz és konzultatív vezetési formához. Ha képes lesz túllépni a politikai lojalitások kusza rendszerén, és formálódó kormányát szakértőkkel, például olyan elismert gazdasági szakemberekkel, mint Ali Babacan, tölti fel, akkor fokozatosan egyre inkább felértékelődnek a rendszerben meglévő fékek és ellensúlyok.

Összefoglalva téziseim visszaigazolást nyertek. Az első előfeltevésem ugyanis az volt, hogy a 2002 és 2013 közötti időszakban az AK Parti kormányok alatt Törökországban demokratizálódási folyamat zajlott. Meggyőződésem ugyanis, hogy a török intézményrendszer 2002 és 2013 között jelentős önállóságot élvezett a kormánytól és csak kevéssé volt érzékelhető a központi hatalom beavatkozásának szándéka és gyakorlata. Demokratizálódás alatt nem csupán azt értem, hogy kiépült egy újfajta intézményrendszer, mely keretet biztosított a vélemények szabadabb megfogalmazására, hanem azt is, hogy a török polgárok és a török államigazgatásban dolgozók is egyre kevesebb kényszerhelyzettel találkozhattak.

Természetesen ahhoz, hogy a török polgárok a politikai rendszerrel szemben megélhessék ezt a pozitív szabadságélményt, magának a rendszernek kellett lényegi módon megváltoznia. Jelzésértékűnek tartom, hogy a 2002-ben hatalomra jutó AK Parti kormány egyik legelső intézkedése a véleményszabadság kiszélesítése felé mutatott. Módosították a Büntető törvénykönyv 312. és az Antiterrorista törvény 7. cikkelyét, ezzel megadták a jogot a törököknek arra, hogy szabadabban formáljanak véleményt. Ezt követően pedig könnyítéseket eszközölt a kormány arra is, hogy a sajtó szabadabban müködhessen, illetve kevésbé szabályozott keretek között lehessen demonstrálni. (ÜSKÜL, 2002, 7) Ezek a kezdeti lépések ahhoz szoktatták hozzá a török embereket, hogy egyrészt folyamatos változások várhatóak az 
egész politikai rendszert illetően, másrészt pedig úgy érezhették, hogy ezek a változások direkt módon kihatnak a magán- és a szakmai életükre, valamint magára a közéletre is.

A 2000-es évek elejét sokan egyfajta felszabadulás élményként élték meg. Ebbe belejátszott az is, hogy 2002 és 2005 között erős stabilizációt figyelhetett meg maga körül mindenki. Ebben az időszakban egy erős kormány vezette az országot, mely nem botrányoktól volt hangos, és mindeközben teret engedett a polgári kezdeményezéseknek, és sokan, elsősorban a kormánypárti szavazóbázis részérőlé úgy érezték, hogy adnak a szavukra és hagyják öket érvényesülni. Ezzel párhuzamosan a civil szférában is élénkülés volt megfigyelhető. Ez utóbbi persze nem csupán a kormányváltással és a politikai stabilitással volt összefüggésben, egy, az 1980-as évek végén meginduló, és az 1990-es évek derekán felerősödő folyamat szerves folytatásaként is értelmezhető. Ugyanakkor az elmondható, hogy látványosan nőtt a polgári kezdeményezések száma, a jelentősebb alapítványok és egyesületek rendezvényei addig nem látott tömegeket vonzottak, és ez a konjunktúra a karitatív tevékenységekre is pozitívan hatott.

A politikai stabilizáció mellett a 2002 és 2005 közötti időszak erősödő gazdasági és pénzügyi stabilizációval is járt, valamint megindult egy elég látványos infrastrukturális fejlesztési éra is, mely -többek között- azt is célozta, hogy csökkenjen a távolság a különböző társadalmi nagycsoportok között és redukálhatóvá váljanak a komoly területi különbségek. Ezen folyamat következtében a török polgárok anyagi lehetőségei javultak, ami a civil társadalom további térnyeréséhez vezetett. Ez utóbbi pedig azt eredményezte, hogy egyre jobban kifejezési módhoz juthattak a különböző hangok, beleértve a kormánykritikus hangokat is.

A törést talán az eredményezhette, hogy az AK Parti kormánya úgy gondolhatta, hogy egyrészt elégséges az infrastruktúra fejlesztése ahhoz, hogy a török társadalom minden egyes problémáját orvosolják, másrészt pedig azt hihették, hogy ez a kézzel fogható eredményeket produkáló politikai eszköz a népet “elvakítja”, és a választók elfogadják majd, hogy az építkezések során komoly természet- és környezetátalakító beavatkozásokat hajtanak végre, illetve ezen beruházásokon keresztül a politikusok rendesen meg is gazdagodnak. A demokratizáció viszont oda vezetett, hogy egyre többen merték kritizálni azt, hogy a döntéshozatal maga egyre kevésbé demokratikus. 2013-ban a Gezi parki események azt mutatták meg, hogy a hatalom, a politikai elit és maga Recep Tayyip Erdoğan is a néptől és a nép véleményétől elszakadva dönt a nép feje felett. Sokan arrogánsnak tartották azt, ahogy a kormány döntött a kedvelt isztambuli zöldfelület beépítéséről, és a demokráciával valamint a szólás- és gyülekezési szabadsággal ellentétesként élték azt meg, ahogy a hatalom reagált. 
Különösképpen a rendőri brutalitás sokkolta a közvéleményt, de Erdoğan szóhasználata, az, hogy útonállóknak nevezte a tüntetőket.

A Gezi parki események jelentősége abban áll, hogy megmutatták, hogy a demokratizálódási folyamat válságba jutott. Az emberek egy része, főleg az ellenzékiek, már nem úgy élték meg a mindennapjaikat, mint a 2002 utáni években, nem érezhették úgy, hogy teljesen szabadon fejezhetik ki a véleményüket, és arra ad is a hatalom. A 2013-as évek másik belpolitikai jelentőségű eseménye, a december végi letartóztatási hullám azt is megmutatta, hogy az elit anyagi értelemben is elszakadhatott a tömegektöl. Az, hogy kormánytagokra és családtagjaikra vetült a korrupció vádja azt sugallta sokak számára, hogy maga a szabadság is relatív lett a török társadalomban. Az elitnek, a kormánytagoknak nagyobb szabadság jut, nagyobb a mozgásterük és könnyebben is gazdagodnak. Ha a török polgár úgy élte meg a 2002 és 2013 közötti időszakot, hogy mind politikai, mind anyagi értelemben növekedett a mozgástere és bővültek a lehetőségei, a 2013-as eseményekből azt szűrhette le, hogy e tekintetben minimum kétsebességes a rendszer: a polgárok messze nem rendelkeznek akkora potenciállal, mint a tőlük egyre inkább elforduló politikai elit.

Az a hipotézisem is visszaigazolást nyert, hogy 2013 és 2018 közötti időszakban az AK Parti kormányok alatt Törökországban demokratizálódási folyamat gyengült. A demokratizálódási folyamat gyengülésének kezdete két ponton fogható meg. Az egyik az volt, hogy a rendőrség brutálisan lépett fel a Gezi parki tiltakozókkal szemben. Ez azért érdekes, mert bár a török rendőrség régebben sem arról volt híres, hogy kesztyűs kézzel bánik az emberekkel, 2002 és 2013 között érezhetően polgárbarátabbá vált. A másik pedig az volt, hogy a 2013 decemberében megfogalmazódott korrupciós vádakra válaszul a kormány nem kivizsgálást kezdeményezett, hanem cinikus módon összeesküvés elméletnek minősítette a történteket. Ez volt az a pont ahol a török átlagember úgy érezhette, hogy míg az elit tagjai akár jogtalanságot is elkövethetnek, a hatalom megvédi őket, addig rá egyre fokozottabb nyomás kerül.

Ugyanakkor fontos megjegyezni, hogy a demokratizálódés gyengülése nem csupán a török választópolgár szubjektív érzése volt 2013-tól kezdve, hanem az események objektív vizsgálata azt is mutatja, hogy a kormány igyekezett a saját szája íze szerint befolyást gyakorolni magára az intézményrendszerre azzal, hogy nyomást helyezett a Bírók és Ügyészek Legfelsőbb Testületére (HSYK). Az addig zajló demokratizálódással volt az is ellentétes, hogy a kormány megpróbált visszaélni a hatalmával, és mindent megtett azért, hogy hamarabb értesüljön a folyamatban lévő nyomozásokról, mint a szélesebb közvélemény. Ugyanakkor az erősödő hatalmi befolyás sem tudta azonnal elcsendesíteni a kritikus hangokat, és a HSYK 
tizenöt tagja is tiltakozott az őket ért támadásokkal szemben. Ez pedig azt mutatja, hogy a 2002 és 2013 bekövetkező demokratizálásnak maradt nyoma a török társadalomban, a civil kurázsi nem épült le azzal, hogy a kormány egyre kevésbé ügyelt a hatalmi ágak szétválasztására. (ÖZBUDUN, 2015, 131)

A demokratizálási folyamat gyengülését mutatja az is, hogy a korrupciós vádak megfogalmazása által keletkezett politikai konfliktusra az AK Parti parlamenti csoportja nem politikai, hanem jogi megoldást keresett. Nem az volt a reakció, hogy vitassák meg, mi okozta a krízist, és vizsgálják ki a vádakat, illetve szükség esetén a jog eszközeivel járjanak el, mint ahogy az egy klasszikus jogállamtól elvárható lenne, hanem szinte azonnal alkotmánymódosítást kezdeményeztek. A kezdeményezés egyébként erős centralizációs törekvésként is értelmezhető, hiszen az eredeti terv szerint a HSYK tagjait vagy azok többségét a parlament választotta volna meg. Ez a reakció végül is azt mutatta meg, hogy míg 2013-ig a jogalkotás a demokratizálás egyik legfőbb eszköze volt, 2013-tól kezdve a hatalommegtartásés koncentrációé szolgálatába állt. (ÖZBUDUN, 2015, 131)

Ez azt jelenti, hogy formai szempontból és a müködés lényegét tekintve Törökország ma is demokratikus szisztémának mondható, ám egyre inkább távolodik attól az eszménytól, amit Európa és az Európai Unió felmutat, illetve egyre jobban az egyszemélyi vezetés kezd el dominálni, ami több problémát is felvet. Ezek közül legtöbb aggály azzal kapcsolatban fogalmazódik meg, hogy a köztársasági elnök túl sok hatalmat von magához akkor, mikor egyedül csak ő dönthet a miniszterek és a vezető kormánytagok személyéről, ő tudja feloszlatni a parlamentet, és ezzel elörehozott választást kiírni. Az új rendszer arra is lehetőséget ad, hogy az elnök -a parlamentet megkerülve- rendeleti úton tudjon kormányozni. A nemzetközi közvélemény azt is a demokratizálódás gyengülésének tekinti, hogy az elnök egy politikai párt tagja is lehet, és ezzel már nem a nemzet egészét, hanem csak saját pártjának érdekét tartja szem előtt. A politikai átrendeződéssel összefüggésben komoly ellenérvként fogalmazódik meg az is, hogy végül az elnök a saját kezében koncentrálta a HSYK egyes tagjainak kinevezését, tehát az, amit 2013 után a parlamenti többség még nem tudott elérni, az elnöki rendszerre való áttérés realizált. (FURTAK, 2017, 2)

\subsection{A demokrácia elmélete és a török valóság}

A 2000-es és 2010-es évek török demokratizálódási folyamata eltérő módon érintette a török társadalom egyes tagjait. Az AK Parti néppártként definiálta magát, a jelszavak szintjén folyamatosan hangsúlyozta a nemzet, a haza és az állam egységességének szükségszerüségét, ugyanakkor a gyakorlatban az egységes nemzetből időnként kirekesztődtek egyes társadalmi 
csoportok. Kimondható, hogy mikor Törökország tekintetében demokratizálódásról sartori esik szó, akkor nem azt értendő alatta, hogy szó szerint mindenki bevonásra kerül a rendszer építése során, hanem inkább egyre bővülő sokaság nevében politizált és politizál az AK Parti. A vizsgált időszakban gyakorlatilag folyamatos a párt népszerűségének és szavazói bázisának terebélyesedése, így ha nem is a nép egésze profitál a folyamatokból, de a török polgárok többsége mindenképpen.

A vizsgált időszakban a demokratizálódás és a nép viszonyrendszerét rousseau-i tekintetben vizsgálva egy kettős folyamat részeként lehet értelmezni. A bővülö támogatói kör egyre komolyabb felhatalmazást is jelent, az AK Parti sajátos törekvései megvalósítása során joggal hivatkozhat arra, hogy jelentős akarat áll lépései mögött. Ugyanakkor azt nem szabad elfelejteni, hogy míg az AK Partival általában lehet, hogy tömegek szimpatizálnak, addig egyes adott kérdésekben már jóval kevesebben értenek egyet a kormány irányvonalával. Erre a legjobb példa az, ha összevetjük a pártlistás szavazások eredményeit a 2017-es alkotmánymódosító népszavazáséval, ahol az AK Parti csupán egy nagyon szerény többséget tudott csak elképzelései mellé állítani. A kettősség ott mutatkozik meg, hogy az AK Parti hatalmának valóban egyre inkább a nép a forrása, az elnöki rendszerre való áttéréssel a nép bizonyos esetekben egyre inkább távol kerül a hatalomtól magától általában, de ez igaz a döntéshozatal folyamatára is.

A demokrácia és a köztársaság fogalma a 19. századi elméleti munkálban egyre inkább összekapcsolódott, hiszen a kor demokratizálódása ráébresztette a gondolkodókat arra, hogy a nép részvétele a döntéshozatalban a modern demokrácia elidegeníthetetlen sajátja. A polgárok felelőssége nem csupán abban áll, hogy megválasztják saját vezetőiket, hanem abban is, hogy a nagy horderejü kérdésekben jogot nyernek arra, hogy maguk is hallathassák a szavukat. A fent hivatkozott népszavazás és az azt megelőző referendumok azt mutatják, hogy az AK Parti igenis kíváncsi volt a nép szavára, az embereket bevonta a legfőbb döntéshozatali aktusokba, és ezzel is növelte saját legitimizációját. A magas részvételi arány mindezeken a voksolásokon pedig azt példázza, hogy a török nép ebben partner is volt.

A 20. századi demokrácia-elméletek a versenygésre helyezik a hangsúlyt. Schumpeter és Seymour Lipset szerint ott van valójában demokrácia, ahol a különböző ideológiák, politikai programok és termékek szabadon mérettetnek meg. (SEYMOUR LIPSET, 1960) Törökország 2002 után is többpártrendszerü demokrácia maradt, ám a verseny sok tekintetben beszükült, egyre inkább az AK Parti hegemóniája figyelhető meg. A valódi verseny ebben a helyzetben nem úgy mutatkozik meg, hogy az ellenzék miként tudja legyőzni a kormánypártot, hanem úgy, hogy a többi párt miként viszonyul az AK Parti által tematizált közélethez és ebben milyen 
helyet kíván betölteni a pártok rendszerében. A nacionalisták esetében például éppen azt hozta az elmúlt másfél évtized, hogy az AK Parti kritikus ellenzékéből, valódi riválisából szoros partnerré avanzsáltak. Ennek a szerepváltásnak az volt az oka, hogy a Bahçeli és az MHP vezetésének több tagja is felmérte azt, hogy az AK Partival zajló versenynél számukra fontosabb a nemzet egységének megőrzése és az egység megteremtése a nemzeti sorskérdésekben. Fontos persze megjegyezni, hogy ehhez a drasztikus változáshoz egy kataklizmára, a július 15-i elvetélt puccsra és az ahhoz kötődő destabilizációs veszélyre is szükség volt.

Seymour Lipset a fent hivatkozott munkájában arra is rámutat, hogy valódi politikai verseny és valódi demokratizálódás csak ott mehet végbe, ahol adottak a gazdasági és infrastrukturális előfeltételek. Magyarán az adott ország népességének fel kell nőnie a demokráciához, amihez a gazdasági fejlődés, a városiasodás és a tudásalapú társadalom kiépülése vezet el. Ez a folyamat Törökországban lényegében már a II. világháború után beindul azzal, hogy megszületik és megcsontosodik a többpártrendszer. Az igaz, hogy ezt az evolúciót rendre megakasztották a katonai puccsok, ám az kétségtelen, hogy a török nép egyre jobban interiorizálta a demokratikus értékeket, a 2016-os puccskísérlet után pedig többféle jelét is adta annak, hogy ragaszkodik a sajátosan török demokráciamodellhez. Törökország tehát nem minden tekintetben hasonlítható össze a dél-amerikai és a kelet-európai új demokráciákkal, ám azt le lehet szögezni, hogy a katonaság fokozatosan leépített túlzó politikai hatalmának eltünése, a társadalom demilitarizálása dolgában felfedezhető némi párhuzam a tranzitológia által vizsgált államok és Törökország között. Magyarán a 2000-es évek törökországi demokratizálási folyamata nem politikai átmenet volt, de radikális változásokkal jellemezhető heves átalakulási folyamat volt.

Érdekes kérdés, hogy ez a heves átalakulási folyamat miképpen érintette egyrészt a hagyományos demokratikus értékek helyzetét Törökországban, másrészt pedig a szekuláris állameszményt egy kulturálisan és civilizációs szempontból is az iszlám világ és a Nyugat határmezsgyéjén egyensúlyozó nemzet esetén. Erdoğan többször is kifejtette, hogy célja, hogy vallásos nemzedékek nőjenek fel Törökországban, (YILMAZ, 2016) ezzel szemben, és annak ellenére, hogy a hatalmon lévő AK Partit sokszor iszlám gyökerünek szokás tekinteni, a török társadalom 2008 és 2018 között fokozatosan hátat fordított annak a vallási és kulturális meghatározottságnak, amire az AK Parti politikai programját és bázisát is építette az elmúlt másfél évtizedben. A Konda közvéleménykutató legrissebb adatai szerint tíz év alatt 55-ről 51\%-ra csökkent azon törökök száma, akik saját magukat vallásos muszlimként definiálják. Ezzel párhuzamosan 1-ről 3\%-ra nőt az ateisták, 1-ről 2\%-ra pedig semmiben nem hívők aránya 
a török társadalomban. (KONDA, 2018) A fentről jövő iszlamizáció nem az iszlám értékek további elterjedéséhez vezetett, hanem egy nem várt és heves elutasító reakcióhoz a társadalom egyik rétegében, míg a potenciális AK Parti szavazók között is egyre inkább felüti a fejét a szkepszis. Gyakorlatilag a népesség tizede veti el azt a politikai iszlámot, amit az AK Parti politikai termékként számukra felkínál. Elméleti szempontból ez úgy is megfogalmazható, hogy míg Erdoğan és pártja Törökországot egyre inkább az iszlám civilizációs közeghez kötné, huntingtoni értelemben fokozatosan zajlik az ország lassú civilizációváltása, nyugatosodása. Persze azt azért nem szabad szem elől téveszteni, hogy a török társadalom még így is jóval vallásosabb, mint az európai átlag, ugyanakkor feltünő az, ami ebben a témában 2008 óta Törökországban lezajlott.

A demokratizálódás az elmúlt évtizedekben fokozatosan összefonódott a nyugatosodással és a nyugati hatalmi centrumok felé való fordulással. A nyugati hatalmi centrumok, így az Európai Unió viszont nem csupán demokratikus közösségként mutatkozik meg ebben az esetben, hanem értékközösségként is. Az elmúlt tizenöt év azt mutatja, hogy Törökország nem került közelebb ehhez az értékközösséghez, az a demokratizáció, ami elsősorban 2002 és 2013 között lezajlott, lehet, hogy az Európai Unió és az integráció kedvéért történt, a koppenhágai kritériumokat vették figyelembe, ám Törökország inkább nevezhető egy sajátos harmadik útnak, mintsem egy nyugat-európai értelemben vett, nyugati értékeken nyugvó államnak. Kérdés persze, hogy célszerü-e a demokrácia fogalmát annyira leszükíteni, hogy abba csak néhány nyugati ország rendszere fér bele.

\subsection{Demokratizálódási szcenáriók}

Mint ahogy azt fentebb már többször említésre került, a török politikai rendszer demokratizálása megtört a 2013-as évben, az eseményeket az elmélettel összevetve pedig az lehet feltünő, hogy míg Törökország demokratizálódott és bír is további demokratizálási potenciállal, nem állítható teljes mértékig nyugati típusú fejlődési pályára. A kérdés végsősoron úgy merül fel, hogy az elnöki rendszerre való áttérés 2018-ban bebetonoz-e egy adott rendszert, vagy csak megmutatja a lehetséges fejlődési keretet, amit megtölthet a török politikai elit és a török társadalom demokratikusabb és kevésbé demokratikus tartalommal is.

Hakkı Taş tanulmányára alapozva négy lehetséges forgatókönyvet érdemes megvizsgálni. (TAŞ, 2018.b, 1) Erdoğan hatalomkoncentrációját látva Taş -mikor az elnökválasztás hátterét elemzi- elég pesszimista jövőképet fest, és ebben nem nehéz osztozni vele. Ugyanakkor kétségtelenül van esély arra is, hogy mindezen negatív utópiákkal szemben újból erősödni fog a demokratizálódás folyamata Törökországban. 
Az első szcenárió szerint állandósul a politikai bizonytalanság Törökországban. Ez a bizonytalanság leginkább a megosztott ellenzéket jellemzi, és több forrása van. Ide sorolható az, hogy a HDP-t folyamatosan a betiltása réme fenyegeti, politikusait bebörtönzik és nem tud teljesen szabadon müködni. Az MHP és a nacionalista közeg még mindig kiforratlan és megosztott. Az MHP csatlakozása az AK Parti ironyvonalához még új, az IYI párt pedig még kialakulatlan és nem igazán körülhatárolható. Nehéz nekik célbajuttatni az üzeneteiket és megszólítani a Bahçeli-féle MHP-ben csalódott tömegeket. A CHP a vizsgált időszakban nem volt képes megújulni. A bizonytalanságot az is növeli, hogy nem könnyü azt meghatározni, hogy kivel és milyen módon találhatna magának jövőt a kemalista tábor. A kormánypárt, az AK Parti sokkal egységesebbnek tünik, egyre kevesebb is a kritikus hang. Bár a politikai- és pártrendszer bizonytalansága általánosságban nem számít pozitívnak, Seymour Lipset óta tudjuk, hogy megtermékenyítheti a politikai versenyt. Jelenleg úgy látszik, hogy ez a bizonytalanság leginkább Recep Tayyip Erdoğannak és az AK Partinak kedvez, hiszen általa képesek hatékonyan megosztani az ellenzéket, és így uralni a politikai szcénát. A bizonytalanságnak van még két mellékterméke is. Egyrészt természetesen az, hogy a török polgárok helyette biztonságra vágynak, és éppen ezért hajlamosak arra voksolni, aki azt el tudja nekik hozni. Éppen ezért sokan úgy vélhetik, hogy a jelenlegi köztársasági elnöknek nincs hozzáértő alternatívája. Másrészt pedig sokakat ez a helyzet elidegeníthet a politikától. Ők azt gondolhatják, hogy ebben a helyzetben történjen bármi, Erdoğan fog győzni.

A második szcenárió szerint egyre nőni fog a rendszerbe kódolt igazságtalanság és egyre kevesebb sikerélmény adatik meg az ellenzéknek. A Gezi parki események közben és után a baloldali ellenzék úgy érezhette, hogy egyrészt képes együtt haladni az eseményekkel, képes érvényes válaszokat adni a felmerülő társadalmi és környezeti kihívásokra, illetve erre vevő is a célközönség. A politikai rendszer egyre jobban az AK Parti állameszményéhez igazodik és egyre jobban eltávolodik attól a köztársaságtól, amit a CHP ideálisnak tart. Ez az ellenzéket folyamatosan frusztrálja és kényszerpályára küldi. A CHP és a többi ellenzéki párt akkor tud ebben a keretben újra sikeresen múködni, ha képes lesz azt az élményt felidézni, amit a Gezi park jelentett nekik. Egy szó, mint száz, el kell hinniük, hogy képesek a török társadalmon változtatni. És el kell hinniük azt is, hogy a nem nekik kedvező rendszerben is tudnak befolyást gyakorolni.

A harmadik szcenárió arra épít, hogy Erdoğan nem áll meg a jelenlegi szinten, nem elégszik meg az elnöki rendszer bevezetésével, hanem minél inkább egyszemélyi vezetési stílust akar megvalósítani. Ez leginkább attól függ, hogy az államapparátus milyen mértékig áll a köztársasági elnök oldalára. Abban az estben ha a közigazgatás az elnök politikai céljait fogja 
szolgálni és leépül a fékek és egyensúlyok rendszere, akkor jelentős mértékben csökken annak az esélye, hogy az AK Partival szemben alternatívát állíthasson az ellenzék, és ennek az üzenetét eljuttathassa a választókhoz. Az államhatalom totális megszállása ugyanakkor Recep Tayyip Erdoğannak és az AK Partinak sem áll érdekében, ugyanis a saját pozícióit is csak akkor tudja erősíteni, ha létezik egy egyfajta politikai verseny. A politikai verseny teljes felszámolása sokkhatást eredményezni a törökök körében, ugyanis a demokrácia kultúrája az elmúlt években meggyökeresedett, és a demokratikus intézményrendszer eltünésével még az AK Parti legradikálisabb hívei sem értenének egyet.

A negyedik szcenárió szerint Recep Tayyip Erdoğan népszerüsége jelentős mértékben le fog csökkeni, és ezzel párhuzamosan megnő az ellenzék mozgástere. A jelenlegi és jelenleg elég népszerü elnök több oknál fogva is veszíthet popularitásából. Mindenképpen ezek között az első a török gazdaság megtorpanás, a török fizetőeszköz mélyrepülése, az árak drasztikus emelkedése és ezzel szembeni adminisztratív és nem gazdasági harc. Az, hogy például hagyma árdrágulása mögött kartelleket sejt a hatalom nem megoldás az ellátási krízis orvoslására, az csupán egy mélyreható gazdasági reformmal orvosolható. Bár a gazdasági válság, a gazdaság diverzifikációjának teljes hiánya, az átgondolatlan privatizáció és a hibás monetáris politika miatt a legérzékenyebben érinti a török polgárokat, és annak a jelei a mindennapokban is egyértelműen érezhetőek még az AK Parti hívei számára is, nem ez az egyetlen kihívás az új elnöki köztársaság elött. Nem szabad megfeledkezni a biztonságpolitikai nehézségekről sem. Erdoğan, annak ellenére hogy látványos hadmüveleteket vezet mind belföldön, mind pedig külföldön a kurd szeparatista és az iszlamista terroristák ellen, az átlagpolgár egyre kevésbé érzi magát biztonságban. Nem beszélve arról, hogy a PKK elleni erőteljes fellépés a kurd kérdés megoldásához sem vitte közelebb az országot. Sőt, elég sok kurdot idegenített el a párttól és a kormánytól. A külhoni harcok pedig ahelyett, hogy elhozták volna Törökországnak az oly áhított regionális hatalmi helyzetet, csak kétes kimenetelü proxy háborúkba sodorta bele az országot. Ez a tekintélyes problémahalmaz persze egy jó vezetés esetén akár kezelhető is, de esélyt is ad arra, hogy a helyzetet az ellenzék is kihasználja, ezzel visszakényszerítse az AK Parti kormányát és Recep Tayyip Erdoğant a 2013 előtt megkezdett demokratizáció útjára.

\subsection{Az elméleti kutatatás további lehetséges irányának meghatározása}

Jelen kutatásom egy időben jól lehatárolható korszakot dolgozott fel, témám a 2002 és 2018 közötti török belpolitikai helyzet volt, az az időszak, amely az AK Parti hatalomra jutása, a Recep Tayyip Erdoğan köztársasági elnökké választása, a török belpolitika átalakulását 
meghatározó 2016-os puccskisérlet és az elnöki rendszerre való áttérés között eltelt. Munkámat tematikus elvek szerint végeztem, a párttörténet és a politikai rendszer általános elemzésén túl kitértem olyan lényeges kérdésekre is mint a kisebbségek helyzete vagy éppen a török társadalom demilitarizálása, mégis adódik, hogy ezt a kutatást a témák további alapos vizsgálatán túl, kronologikusan is folytathatom.

Egyrészt kézenfekvő az az egyszerü megközelítés, amely az elnökválasztás óta eltelt időszakot veszi górcső alá. Az elmúlt szük esztendő bővelkedett történésekben. Meg lehet tüzetesebben vizsgálni Ahmet Davutoğlu tevékenységét az AK Parti-kormány élén, és azt is, hogy a nemzet egységét megtestesíteni hivatott új, a nép által választott köztársasági elnök milyen szerepet töltött be a politikai életben. A kutatás megkezdése óta eltelt időszakban számos komoly változás állt be a török belpolitikai életben. Mindezek közül kettő mindenképpen hosszútávú és strukturális változásokhoz vezet és fog vezetni.

Az egyik ilyen esemény a 2016. július 15-én lezajlott véres puccskísérlet, mely során a fegyveres erők egy csoportja fellázadt a demokratikusan választott, polgári kormányzattal, ám nagyjából egy nap után és mintegy 250 halálos áldozat árán kénytelen volt belátni, hogy nincs esélye a törvényes államvezetés megdöntésére. A török kormány a Pennsylvániában élő hitszónokot, Fethullah Gülent és mozgalmát tette felelőssé, nagy számban tartóztatták le a Hizmet tagjait és támogatóit, illetve rendkívüli állapotot vezettek be az országban. Az elbukott államcsínynek négy rendkívül fontos következménye van. Egyrészt az AK Parti és Recep Tayyip Erdoğan hatalmát veszélyeztető Gülen mozgalom elszigetelődik, a hozzá köthető szervezetek betiltásával, vagyonuk államosításával a kormány garantálni tudta, hogy a Hizmet politikai befolyádsa limitált, további hatalomátvételi kísérleteiknek az esélye minimális. Másrészt a rendkívüli állapotból fakadóan a 2016 nyara utáni időszakra leginkább a rendeleti úton való kormányzás vált jellemzővé, ez pedig tovább koncentrálta az AK Parti-kormány hatalmát. Harmadrészt a felfokozott centralizáció átstruktúrálta az AK Parti ellenzékét. Egyes pártok (MHP, BBP) a puccskísérletet úgy értékelték, hogy az egy nemzeti vészhelyzet, melyben a nemzeti erőknek a központi hatalom erősítésén kell dolgozniuk. Más ellenzéki erők, így az újonnan a MHP-ból kivált IYI párt, a CHP és a SP egy új ellenzéki pólus felépítésén munkálkodnak, ám ez oldal még nem jutott el a szervezettség azon fokára, hogy valódi alternatívát tudjanak kínálni az AK Partival szemben, pedig a 2017-2018-ban egyre romló gazdasági mutatók mellett erre reális esély nyílna. Negyedrészt az államcsíny kísérlete jó indok a kormány számára, hogy folytassa és egyben be is bejezze a török társadalom és politika totális demilitarizálását. A másik jelentős változás a politikai rendszer szerkezeti átalakítása volt. 
Az államberendezkedés jelentős átalakítása után az egyik lehetséges kutatási irány a hatalmi ágak egymáshoz való viszonyának vizsgálata. Az egyik izgalmas pont az elnöki vétó intézménye lehet, mely előre vetíti egyrészt a köztársasági elnök és a nemzetgyülés közötti rivalizálást, másrészt arra fogja kényszeríteni a parlamenti képviselőket, hogy minél inkább konszenzusra törekedjenek a törvényhozói munka során.

Szintén hasznos lehet megvizsgálni, hogy alakult át a pártrendszer a puccskísérlet hatására, illetve milyen további változások várhatóak annak köszönhetően, hogy megjelent a színen egy új párt, az IYI és vezetői bebörtönzése ellenére talpon maradt a HDP. Az is ígéretes lehetőséget kínál a kutatók számára, hogy az ideológiailag különböző pártok, a kemalista CHP, a nacionalista IYI és az iszlamista gyökerü SP tud-e egy „,népfrontot” létesíteni, képesek leszneke félretenni az ideológiai eltéréseket az AK Parti és Erdoğan megdöntése érdekében. Emellett kereshetjük arra a kérdésre is a választ, hogy a hadsereg tud-e még politikai befolyásra szert tenni Törökországban, illetve lehet-e valós hatása még a török társadalomra Fethullah Gülennek és mozgalmának.

A török demokráciát belső dinamikáján túlmenően érinti a külső környezete is. Törökország a Közel-Kelet szomszédságában, diktatúrák és polgárháborúk közvetlen közelében, ezektől veszélyeztetve éli életét, így a török demokrácia bátorításra szorul. A legfontosabb megerősítés pedig csakis Nyugatról jöhet. A rendszer maximális stabilitását az adhatná meg, ha Törökország hosszadalmas várakozás után beléphetne az Európai Unióba. Ezért úgy gondoljuk, hogy a belpolitika vizsgálatán túl a fö kutatási iránynak Törökország euroatlanti integrációjának kell lennie. „Négy olyan terület van, melyet az AK Parti illetékesei az EU-val való együttmüködés kulcskérdéseinek tartanak, ezek nevezetesen a demokrácia és az emberi jogok megerősítése (egyesek egyenesen a török politikai élet tovább civilizálásáról is beszélnek), a gazdasági kapcsolatok, a jó kormányzás (good governance), amit az EU joganyagainak, az ún. acquis-nak az alkalmazásával lehet elérni és a külpolitika, beleértve az energiaügyet is." (AYDIN-CAKIR, 2007, 10)

A török demokráciát és azon belül az AK Parti esetét hosszú ideig példaértékünek tartotta a nemzetközi közvélemény. Sokan úgy gondolták, hogy az arab tavasz során csődöt mondott iszlám demokratizálási törekvéssel szemben alternatíva lehet az, amit az $\mathrm{AK}$ Parti Törökországban tesz. Az elnöki rendszerre való áttérés viszont azt jelenti, hogy a török politikai rendszer kezd hasonlítani az arab világban megszokott elnöki szisztémákhoz. Ha ez igaz, azt is fontos lenne megvizsgálni, hogy Törökország még mindig modellértékü-e az iszlám világ 
számára, avagy éppen fordítva, az iszlám világ részletesebb ismerete vezet el minket Törökország jobb megértéséhez.

\subsection{Az elmélet gyakorlati haszna}

Elméletem több gyakorlati haszonnal is bír. Ezek két szinten értelmezhetőek: egyrészt a török belpolitika területén, másrészt modellként tekintve az elméletre más, nem nyugati demokráciák viselkedésének vizsgálatakor.

Elméletem elsősorban a törökországi politikai folyamatok megértését szolgálja. A hosszú ideig irányító politikai formációknak sajátos dinamikájuk van, népszerüségük és befolyásuk általában hullámzó. Az AK Parti és a Törökországot kormányozni szándékozó pártok számára kiemelten fontos, hogy megértsék, hogyan is érhető el a több cikluson át történő, komoly népszerüségvesztés nélküli politizálás úgy, hogy a kormány közben megvalósítja értékelvü és hosszú távra tervezett politikai programját. Az AK Parti tizenhét éves törekvéseiben azt láthatjuk, hogy az ország fejlesztése mellett egy határozott társadalmi reform zajlott le, egy olyan reform, ahol azok kaptak esélyt, akik azelőtt hosszú ideig nem. Ezek szerint Törökországban - mint ahogy persze más országokban is - fontos az, hogy a legfőbb választói bázis megerősítést kapjon, illetve főbb követeléseik megvalósuljanak. Az AK Parti annyiban volt más ebben a tekintetben, mint egyéb pártok, hogy egyrészt tevékenységét nem korlátozta egyes szük elit körökre, másrészt hosszú ideig tett gesztusokat az ellenoldal felé is. Az AK Parti szociálpolitikája, azon belül az infláció- és munkanélküliség-ellenes intézkedései, a munkahelyteremtés és a lakásépítési programok nagyon sok kisember életét tették könnyebbé. Az ország szegény régióban a lakosság többsége (Batman megyében a háromnegyede) ma állami támogatásokból, segélyekből él. A szociálpolitikai lépések mellett kiemelendő az infrastruktúra fejlesztése is. Az AK Parti bár sokat költ a fejlettebb nyugati régiókban presztízs beruházásokra, mintaharmadik isztambuli hídra, ám közben több ezer kétszer kétsávos autóutat és autópályát, repülőtereket és egyetemeket is létrehozott az ország délkeleti területein. Ezekben a körzetekben gyakorta olyanok élnek, akik nem tartoznak a párt törzsszavazói közé, amiből arra következtethetünk, hogy egy párt sem lehet sikeres, és kormányozhatja tartósan Törökországot, csak akkor, ha olyan „nemzetegyesítő” programmal lép fel, mely mindent megtesz az esélyegyenlőtlenségek eltörlése érdekében.

Az AK Parti 2002 óta tartó kormányzása arra bizonyíték, hogy a török nemzet egyesítése nem etnikai alapon, s nem is nemzeti szlogenek puszta hangoztatásával, hanem az esélyegyenlőtlenségek csökkentésével érhető el. Egy olyan országban, ahol erős a ragaszkodás 
a török politikai nemzethez, de emellett számos etnikai identitás (kurd, láz, cserkesz, zaza stb.) él ezzel párhuzamosan, és ahol épp a nemzetiségek által lakott térségek az elmaradottak, nem a többségi nemzet erősítése vagy a kisebbségi jogok kiszélesítése hozhatja el a hőn áhított egységet, hanem az, hogy az ország minden pontján ugyanazok a szolgáltatások válhassanak elérhetővé. Hosszú távon tehát az a párt lesz sikeres, mely felzárkóztatja a délkeleti régiót.

Emellett persze nem szabad kisebbíteni az ún. „kurd nyitás” jelentőségét sem. Mint az előbb említettük a török politikai nemzethez tartozáson túl egyre fontosabb a török állampolgárok számára az ún. altkimlik, azaz az a másodlagos identifikációs erő, ami a vérségileg öröklött etnikai identitáshoz köthetö. Egy teljeskörü infrastrukturális fejlesztés mellett sem érezheti egészen szabadnak magát az, aki például az anyanyelvét nem használhatja az élet minden területén, vagy éppen nem gyakorolhatja szabadon a vallását. Ezeket a követeléseket a török politikában elöször az AK Parti hallotta meg abban az értelemben, hogy kisebbségi nyelvű TV- és rádióadásokat vagy éppen iskolákat engedélyezett. Ugyanakkor a kisebbségi jogok kérdése egy olyan törékeny régióban, mint amilyen a Szíriával és Irakkal is határos Törökországé, felvet még egy kérdést: hogyan őrizhető meg a politikai nemzet politikai egysége a növekvő szabadság mellett? A kurdok autonómiát élveznek Irakban, saját fegyveres erőik vannak mindkét szomszédos arab állam területén. Ez természetesen veszélyezteti Törökország területi egységét. Az AK Partinak mindent meg kell tennie annak érdekében, hogy az iraki kurd autonómia és a szomszédban zajló polgárháború ne jelenthessen közvetlen fenyegetést. Ezt az esetleges fegyveres csapásoknál sokkal jobban szolgálja az, hogy a kurd autonómiát a kormány diplomáciája partnerként tekinti. A kurd kérdés békés rendezése mind a kurdok, mind pedig a török kormány érdeke. Jól látható, hogy az országban legrégebb óta fennálló és még mindig rendezetlen ügy éppen ez. Az sem mellékes, hogy a kurd kérdés úgy nem tudott még nyugvópontra jutni, hogy az AK Parti -a kurd nyitás politikája során- komoly engedményeket is tett a nevezett kisebbség számára.

Ha a társadalom többségének értékei mentén zajló nemzetegyesítés sikeres, akkor modellként szolgálhat és példaértékü lehet minden olyan nem nyugati ország számára, ahol a demokrácia vagy az elmúlt évtizedekben szilárdult meg, vagy nem tudott szerves fejlődésen keresztül menni. Ezen kívül Törökország útja ihletül szolgálhat a ma még kaotikus arab világ egyes államai részére is. Törökország demokratizálódása ugyan az 1940-es évek végén kezdődött, és az első szabad választásokat már 1950-ben megtartották, de a rendszeres katonai puccsok több esetben megakasztották a szerves fejlődést. A török demokrácia az AK Parti kormányzása idején azért is élhetett meg több nyitottságot, mert háttérbe szorította a katonaságot. Ez példa lehet mindazon országok számára, köztük egyes türk nemzeteknek is, 
ahol a demokratikus átmenet ellenére a hadsereg túlzott hatalommal bír. Viszont az sem kívánatos, ha egyes új demokráciák ,átesnek a ló másik oldalára”, azaz szinte teljesen leépítik hadseregüket, védtelenné teszik az országot. Törökország a demilitarizálás mellett sokat költ hazai katonai fejlesztésekre, és megfelelő szinten tartja a fegyveres erők csapásmérő képességét.

A külföld számára, és főleg a nyugati szemlélőnek fontos konklúzió, hogy az AK Parti kormányzása a legjobb példa arra, hogy muszlim közegben is jól müködhet egy szekuláris demokrácia. „Bár az AK Parti az iszlamista Milli Görüsből ered, elsajátított egy egyfajta passzív szekularizmust és a globalizáció támogatójává vált.” (KURU, 2011, 150) 


\section{Irodalomjegyzék}

- ADEM, Çiğdem [2005]: Non-State Actors and Environmentalism. In F. Adaman, M. Arsel (szerk.): Environmentalism in Turkey, Between Democracy and Development. Ashgate Publishing, Farnham

- AINSLIE, Geoffrey [2012]: Strategic Depth \& the AK Parti: Emerging Opportunities in a New Regional Order. Amherst College, Amherst

- AK PARTI [2002]: Herşey Türkiye için. AK Parti, Ankara

- AK PARTI [2007]: Güven ve İstikrar içinde Durmak Yok Yola Devam. AK Parti, Ankara

- AK PARTI [2011]: Türkiye Hazır, Hedef 2023. AK Parti, Ankara

- AKAR, Atilla [2002]: Öteki DSP: Ecevitlerin gayri resmi öyküsü. Metis Yayınları, Isztambul

- AKÇURA, Belma [2008]: Devletin Kürt filmi: 1925-2007 Kürt raporlarl. Ayraç Yayınları, Ankara

- AKDAĞ, Gül Arıkan [2015]: Ethnicity and Elections in Turkey: Party Politics and the Mobilization of Swing Voters. Routledge, Abingdon

- AKDOĞAN, Yalçın [2004]: Muhafazakar Demokrasi. Ak Parti, Ankara

- AKGÜN-COP-EMRE-YESEVİ [2014]: Gezi Parkı'nda Ne Oldu? - Katılımcıların Penceresinden Bir Gezi Parkı Değerlendirmesi. T. C. İstanbul Kültür Üniversitesi, Isztambul

- AKINCI, Abdulvahap: Türkiye’nin Darbe Geleneği: 1960 ve 1971 Müdahaleleri. in:

Eskişehir Osmangazi Üniversitesi İIBF Dergisi, 9/1 (2014) pp. 55-72

- AKINER-AKBULUTGILLLER-ERKAN: Dershane Tartışması: AK Parti İktidarı ve Gülen Hareketi Arasındaki Uyuşmazlı̆̆a Dair Haber Söylemi. in: Sosyal Bilimler Dergisi, 16/2 (2014) pp. 87-113

- AKKAN, Ahmet Turan (szerk.) [2012]: Derin Devlet, AK Parti ve Kürtler. Küre Yayınları, Isztambul

- AKNUR, Müge [2012]: Democratic Consolidation in Turkey. Universal Publishers, Boca Raton 
- AKNUR, Müge: Civil-Military Relations During the AK Party Era: Major Developments and Challenges. in: Insight Turkey, 15/4 (2013) pp. 131-150

- AKTÜRK, Şener [2013]: Türkiye'nin Kimlikleri - Din, Dil, Etnisite, Milliyet, Devlet ve Medeniyet. Etkileşim, Isztambul

- AKYOL-SEZGIN (szerk.) [2009]: Cözümün şafağında Kürt sorunu. Özgür Yayınları, Isztambul

- ALKIŞ, Erdal [2013]: AK Parti yürüyüşü: ilk 45 gün. KaraKutu yayınları, Isztambul

- ANADOLU AJANSI Genel Müdürlüğü Görsel Haberler Yayın Yönetmenliği ve Kurumsal İletişim Direktörlüğü [2016]: Dakika Dakika FETÖ’nün Darbe Girişimi - 15-20 Temmuz 2016. ANADOLU AJANSI Yayınları - 27, Ankara

- ARAT, Yeşim [2005]: Rethinking Islam and Liberal Democracy - Islamist Women in Turkish Politics. State University of New York Press, Albany

- ARSLAN, Zühtü: Başörtüsü, AK Parti ve Laiklik - Anayasa Mahkemesinden İki Karar Bir Gerekçe. SETA, Ankara, 2009

- ASLANDAŞ-BIÇAKÇI [1995]: Popüler Siyasî Deyimler Sözlüğü. İletişim, Isztambul

- AŞGIN, Sait: Atatürk Döneminde Doğu Anadolu (1923-1938). in: Atatürk Araştırma Merkezi Dergisi, 17/50 (2011) pp. 451-472

- ATA, Kelime [2007]: Alevilerin ilk siyasal denemesi (Türkiye) Birlik Partisi (1966-1980). Kelime Yayınevi, Isztambul

- ATILGAN, Meral: Avrupa Birliği, Azınlık Hakları ve Türkiye. in: Türk İdare Dergisi, 450 (2006) p. 43-65

- AVŞAR, Gülçin [2013]: Ergenekon'un Öteki Yüzü: Faili Meçhuller ve Kayıplar Ergenekon Dosyaları Incelemesi. TESEV Yayınları, Isztambul

- AVŞAR-KAYA: Çok Partili Hayata Geçiş Sonrasında İlk Muhalefet Partisi: Milli Kalkınma Partisi. in: C.Ü. İktisadi ve İdari Bilimler Dergisi, 13/2 (2012) pp. 113-132

- AXIARLIS, Evangelia [2014]: Political Islam and the Secular State in Turkey - Democracy, Reform and the Justice and Development Party. Tauris, London 
- AYATA-YEŞİLADALI [2013]: Gezi Parkı Olayları: Insan Hakları Hukuku ve Siyasi Söylem Işı̆̆ı̆nda bir İnceleme. İstanbul Bilgi Üniversitesi Yayınları, Isztambul - AYDEMİR, Işık: İki Fransiz Mimarı Henri Prost ve August Perret'nin İstanbul ile İlgili Çalışmaları. in: Megaron Dergisi 3/1 (2008) pp. 104-111

- AZERI, Siyaves: The July 15 Coup Attempt in Turkey: The Erdogan-Gulen Confrontation and the Fall of 'Moderate' Political Islam, Critique, 44/4 (2016), pp. 465-478

-BALOGH István, N. RÓZSA Erzsébet, RADA Csaba, SZALAY Máté [2013]: Kapacitások és ambíciók: a török közel-keleti külpolitika alapjai. MKI Elemzések

- BAŞGİL, Ali Fuad [1966]: 27 Mayis ihtilali ve sebepleri. Kubbealtı Neşriyat1, Isztambul

- BAYHAN, Fatih [2007]: Recep Tayyip Erdoğan'ın Liderlik Şifreleri. Pegasus, Isztambul

- BAYAT, Asef [2013]: Post-Islamism - The Changing Face of Political Islam. Oxford University Press, Oxford

- BAYRAM, Salih [2016]: Türkiye'de Başkanlık Sistemi Tartışmaları - Algılar, Argümanlar ve Tezler. SETA, Ankara

- BAYTAL, Yaşar: Demokrat Parti Dönemi Ekonomi Politikaları. in: Ankara Üniversitesi Türk Inkilap Tarihi Atatürk Yolu Dergisi, 40 (2007) pp. 545-567

- BELGE-EGRESI: Development of Islamic Banking in Turkey. in: Annals of the „Constantin Brâncuşi” University of Târgu Jiu, Economy Series 6. szám (2015), pp. 5-20

- BİLGIN, Fevzi [2012]: Resolving Turkey’s Kurdish Issue. Rethink Institute, Washington DC

- BİLGIN, Fevzi [2012]: The Challanges of Democracy and Press Freedom in Turkey.

Rethink Institute, Washington D.C.

- BILLGIN- SARIHAN (szerk.) [2013]: Understanding Turkey's Kurdish Question. Lexington Books, Lanham

- BOZTAŞ Asena: Türk Demokrasisine Müdahaleler. in: Mustafa Kemal Üniversitesi Sosyal Bilimler Enstitüsü Dergisi 9/19 (2012) pp. 65-73

- BUĞRA-SAVAŞKAN [2014]: New Capitalism in Turkey: The Relationship between Politics, Religion and Business. Edward Elgar Publishing, Cheltenham 
- BUKHARI, Mohammad ibn Abdullah [1996]: The English Translation of Sahih Al Bukhari With the Arabic Text (9 volume set). Al-Saadawi Publications, Alexandria

- CSICSMANN - N. RÓZSA: A Török Köztársaság az átalakuló Közel-Keleten. in: Külügyi Szemle, 12/1 (2013) pp. 59-78.

- ÇAĞAPTAY, Soner [2014]: The Rise of Turkey: The Twenty-First Century's First Muslim Power. University of Nebraska Press, Lincoln

- ÇAKIR, Ezgi: 16 Nisan Referandum Sürecinde Başkanlık Sistemi Tartışmalarının Türk Basınına Yansımaları. in: İnsan ve İnsan, 4/14 (2017), pp. 273-300

- ÇAKIR, Ruşen [2004]: Türkiye’nin Kürt sorunu. Metis Yayınları, Isztambul

- ÇANDAR, Cengiz [2001]: Dağdan Iniş - PKK Nasıl Silah Bırakır? - Kürt Sorunu'nun Şiddetten Arındırılması. TESEV Yayınları, Isztambul

- ÇARKOĞLU, Ali, KALAYCIOĞLU, Ersin [2010]: Türkiye'de Dindarlı: Uluslararası Bir Karşılaştırma. Sabancı Üniversitesi

- ÇARKOĞLU, Ali [2014]: Turkey Goes to the Ballot Box - 2014 Municipal Elections and Beyond. Brookings, Washington, D.C.

- ÇARKOĞLU-KALAYCIOĞLU [2007]: Turkish Democracy Today - Elections, Protest and Stability in an Islamic Society. Tauris, London

- CIZRE, Ümit [2008]: Secular and Islamic Politics in Turkey - the making of the Justice and Development Party. Routeldge, Abingdon

- ÇETIN, Bilal [2003]: Türk Siyasetinde Bir KASIMPAŞALI. Gündem, Isztambul

- DAVIDSON, Roderic H. [1973]: Reform in the Ottoman Empire, 1856-1876. Gordian Press, New York

- DEMİR-ÇAĞLAR [2017]: FETÖ’nün 15 Temmuz Darbe Girişiminin İletişim Stratejisi. SETA, Ankara

- DEMIR-ÇOHADAR-GÖK: Cumhurbaşkanlı̆̆l Hükümet Sisteminin Yönetişimin Temel İlkeleri Bağlamında İncelenmesi. in: Strategic Public Management Journal, 3. évf., különszám (2017), pp. 138-153 
- DEMİREL, Tanel [2004]: Adalet Partisi: ideoloji ve politika. İletişim Yayınları, Isztambul.

- DEMİREL, Tanel [2010]: 2000'li Yıllarda Asker ve Siyaset - Kontrollü Değişim ile Statüko Arasında Türk Ordusu. SETA, Ankara

- DERVIŞS-EMERSON-GROS-ÜRGEN (szerk.) [2004]: The European Transformation of Modern Turkey. Center for European Policy Studies, Brüsszel

- DERVIŞ, Kemal [2006]: Ikki bin'li yıllarda Türkiye'nin büyüme süreci ve temel sorunları.Türkiye Bilimler Akademisi, Ankara

- DESCH, Michael C. [2001]: Civilian Control of the Military: The Changing Security Environment. John Hopkins University Press, Baltimore

- DIAMOND-GUNTHER [2001]: Political Parties and Democracy. The Johns Hopkins University Press, Baltimore

- DOĞANAY, Taylan Can: Adalet ve Kalkınma Partisi'nin Muktedir Iktidart ve Sistem Meşrulaştırması. in: KMÜ Sosyal ve Ekonomik Araştırmalar Dergisi 16/27 (2014) pp. 65-72

- DÖŞEMECİ, Mehmet [2013]: Debating Turkish Modernity: Civilization, Nationalism, and the EEC. Cambridge University Press, New York

- DUFNER-BICO (szerk.) [2008]: Türkiye'de Kürtler: barış süreci için temel gereksinimler. Heinrich-Böll-Stiftung, Berlin

- DURAN-AKGÜN-YÜCEL [2017]: Iddianamelerde 15 Temmuz Darbe Girişimi ve FETÖ. SETA, Ankara

- DURAN, Burhanettin: JDP and Foreign Policy as an Agent of Transformation in: YAVUZ, Hakan [2006]: The Emergence of a New Turkey-Democracy and the AK Parti. The University of Utah Press, Salt Lake City p. 295

- DURAN, Hazal [2017]: Meral Akşener’in Siyasi Anlamı ve İYİ Parti. SETA, Ankara

- ELIGÜR, Banu [2010]: The Mobilization of Political Islam in Turkey. Cambridge University Press, Cambridge

- ECCARIUS-KELLY, Vera [2011]: The Militant Kurds: A Dual Strategy for Freedom. ABC-CLIO, Santa Barbara 
- EGERESI Zoltán [2014]: What's next for Turkey? Lessons of the 2014 presidential elections. Institute of International Relations, Prága

- EGERESI Zoltán: A PKK: Marxista terrorszervezetből nemzetépitö gerillahadsereg? in: Pro Minoritate, 21/2 (2012) pp. 93-112

- EGERESI Zoltán [2013]: Békefolyamat Törökországban : útban a történelmi kiegyezés felé? Magyar Külügyi Intézet, Budapest

- EGERESI Zoltán [2013]: Az AKP keresztutak elött. Magyar Külügyi Intézet, Budapest - EGERESI, Zoltán [2013]: Törökországi zavargások. Magyar Külügyi Intézet, Budapest - ELIGÜR, Banu [2010]: The Mobilization of Political Islam in Turkey. Cambridge University Press, Cambridge

- EMBER-EMBER-SKOGGARD (szerk.) [2005]: Encyclopedia of Diasporas - Immigrant and Refugee Cultures Around the World. Springer-Verlag US, New York

- ERICKSON, Edward [2013]: Mustafa Kemal Atatürk. Osprey Publishing, Oxford - ERLER, Özgün: Yeni Muhafazakarlık, AKP ve "Muhafazakar Demokrat" Kimliği. in: Stratejik Araştırmalar Dergisi, 10 (2007) pp. 126-132

- ERTEM-ESAYAN [2013]: Dünyayı Durduran 60 gün. Etkileşim, Isztambul

- ESAYAN, Markar [2014]: 30 Mart'a doğru - Adalet ve Kalkınma Partisi. SETA, Ankara

- ETE-AKBABA-DALAY-ERSAY-KANAT-ÜSTÜN [2014]: Turkey's 2014 Local Elections. SETA, Ankara

- ETE-TAŞDELEN-ERSAY [2014]: Ülkücülükten Tepkisel Milliyetçiliğe: MHP'nin İdeolojisi ve Seçmen Ĕ̈ilimleri. SETA, Ankara

- ETE-TAŞTAN [2013]: Kurgu ile Gerçeklik Arasında Gezi Eylemleri. SETA, Ankara

- FABBE, Kristin [2016]: Why there are so many conspiracy theories about the Turkish coup. In: The Project on Middle East Political Science Briefings, 30

- FINKEL, Andrew [2012]: Turkey: What Everyone Needs to Know. Oxford University Press, Oxford 
- FLESCH István [2004]: Atatürk és kora - Musztafa Kemál Atatürk függetlenségi háborúja. Corvina, Budapest

- FLESCH, István [2007]: A Török Köztársaság története. Corvina, Budapest

- FORSTER, Atnhony [2006]: Armed Forces and Society in Europe. Palgrave Macmillan, New York

- FURTAK, Florian: Democracy Under Pressure: The Case of Poland, Hungary and Turkey. in: Journal of Civil \& Legal Sciences, 6/2, pp. 1-2

- GELLNER, Ernest [1983]: Nation and Nationalism. Blackwell Publishing Ltd., Oxford - GÖKAY-XYPOLIA [2013]: Reflections on Taksim-Gezi Park Protests in Turkey. Keele Research Centre, Keele

- GÜLENER-MIŞ [2017]: Cumhurbaşkanlı̆̆ı Sistemi. SETA, Ankara

- GÜNEŞ, Cengiz [2012]: The Kurdish National Movement in Turkey: From Protest to Resistance. Routledge, Abingdon

- GÜNEŞ-ZEYDANLIOĞLU (szerk.) [2014]: The Kurdish Question in Turkey: New Perspectives on Violence, Representation and Reconciliation. Routledge, Abingdon - GÜRCAN, Metin: The Ankara Bombings and the Islamic State's Turkey Strategy. in: CTC Sentinel, 8/10 (2015), pp. 27-29

- GÜRCAN-PEKER [2015]: Challenging Neoliberalism at Turkey's Gezi Park: From Private Discontent to Collective. Palgrave Macmillan, New York

- GÜRSOY, Yaprak [2012]: Turkish Public Attitudes Toward the Military and Ergenekon: Consequences for the Consolidation of Democracy. Istanbul Bilgi University, Isztambul

- HAKYEMEZ, Serra [2017]: Turkey's Failed Peace Process with the Kurds: A Different Explanation. Brandeis University, Crown Center for Middle East Studies, Middle East Brief, No. 111

- HAKYEMEZ, Yusuf Şevki [2003]: Çoğunlukçu demokrasi anlayişi, Rousseau ve türk anayasalari üzerindeki etkisi. in: Ankara Üniversitesi Hukuk Fakültesi Dergisi. Vol. 52, No. 4. p. 69-72. 
- HALE-ÖZBUDUN [2010]: Islamism, Liberalism and Democracy in Turkey - The case of the AKP. Routledge, Abingdon

- HAUGOM, Lars [2019]: The Turkish Armed Forces and Civil-military Relations in Turkey after the 15 July 2016 Coup Attempt. in: Scandinavian Journal of Military Studies, 2/1, pp. 18.

- HENDRICK, Joshua [2013]: Gülen: The Ambiguous Politics of Market Islam in Turkey and the World. New York University Press, New York

- HERPER, Metin [2008]: Devlet ve Kürtler. Doğan Kitap, Isztambul

- HERPER-SAYARI [2002]: Political Leaders and Democracy in Turkey. Lexington Books, Lanham

- HOLTON-LOPEZ [2015]: The Gulen Movement - Turkey's Islamic Supremacist Cult and its Contributions to the Civilization Jihad. The Center for Security Policy, Washington DC

- HUDECZ Gergely [2007]: Demokrácia és demokratizálódás. in: Kül-Világ. 4. évf., 2. szám. 19-31.

- HUGHES, Edel [2011]: Turkey's Accession to the European Union: The Politics of Exclusion? Routledge, Abingdon

- HUNTER-MALIK [2005]: Modernization, Democracy and Islam. Greenwood Publishing Group, Praegar Publishers, Westport

- İBA, Şaban [2008]: Sevr'den Lozan'a Kürt sorunu ve Kemalist hareket. Maki Basın Yayınları Limited, Ankara

- İBRAHIM-GÜRBEY (szerk.) [2000]: The Kurdish Conflict in Turkey: Obstacles and Chances for Peace and Democracy. LIT Verlag, Münster

- İÇDUYGU-MEYDANOĞLU-SERT [2011]: Türkiye'de Sivil Toplum: Bir Dönüm Noktast. TÜSEV Yayınları, Isztambul

- İZGÜ, Muzaffer [2013]: Çapulcu musun? Vay vay. Bilgi Yayınevi, Ankara

- IŞIKLAR, Celal [2011]: Dünyada ve Türk hukukunda zorunlu askerlik ve vicdanî ret. Adalet Yayınevi, Ankara 
- KAHRAMAN-YENER [2007]: Türk sađ̆ğı ve AKP. Agora kitaplı̆̆ı, Isztambul

- KALAYCIOGLU, Ersin: The Motherland Party: The Challenge of Institutionalization in a Charismatic Leader Party. in.: Turkish Studies 3/1 (2002) pp. 41-61

- KANTAR, Gökmen: Türk Siyesetinde Politik Dil Kullanımı: Binali Yıldırım, Kemal Kılıçdaroğlu ve Devlet Bahçeli’nin; 7 Ağustos 2016 „Demokrasi ve Şehitler Mitingi” Söylemlerinin İçerik Analizi. in: Yüzüncü Y11 Üniversitesi İktisadi ve İdari Bilimler Fakültesi Dergisi, 1/2 (2016), pp. 184-213

- KAPLAN, Sefa [2001]: Kemal Derviş: bir "kurtarıcı" öyküsü. Metis Yayınları, Isztambul - KARAGÖL, Erdal Tanas [2013]: AK Parti Dönemi Türkiye Ekonomisi. SETA, Ankara - KARAGÖL-ORTAKAYA [2014]: Geçmişten Günümüze Kamu Maliyesi. SETA, Ankara - KARAKUŞ, Olcay [2006]: Avrupa Birliği Uyum Sürecinde Türkiye'deki Sivil Toplum Kuruluşları. T. C. Süleyman Demirel Üniversitesi, İsparta

- KARATAŞ, Yılmaz [2014]: Demokratik Barışçı Çözüm ve Kürt Sorunu. Doğa Basın Yayın, Isztambul

- KARPAT, Kemal [2010]: Daği Delen Irmak. Timaş Yayınları, Isztambul

- KATUS László [1970]: Musztafa Kemál Atatürk. Akadémiai kiadó, Budapest

- KAYA, Burak: Türk Tipi Başkanlık Sistemi Önerisinden Partili Cumhurbaşkanlığı Sistemine. in: Yönetim Bilimleri Dergisi 15/30 (2017), pp. 27-50

- KAYA, Rıdvan [2007]: Değişen sürecinde AK Parti ve Müslümanlar. Ekin yayınevi, Bursa

- KAYAALP, Ebru [2014]: Remaking Politics, Markets and Citizens in Turkey: Governing Through Smoke. Bloombbury Academic, London-New York

- KEREKESHÁZY József [1943]: Az igazi Kemál: egy köztársaság születése. Pantheon, Budapest

- KEYMAN, Fuat [2006]: Türkiye'de Sivil Toplum Serüveni - Imkansızlıklar içinde bir vaka. STGM, Ankara 
- KEYMAN, Fuat [2008]: Remaking Turkey: Globalization, Alternative Modernities and Democracy. Lexington Books, Lanham

- KEYMAN, Fuat: The AK Party: Dominant Party, New Turkey and Polarization. in: Insight Turkey, 16/2 (2014) pp. 19-31

- KEYMAN-GUMUSCU [2014]: Democracy, Identity and Foreign Policy in Turkey, Hegemony Through Transformation. Palgrave MacMillan, Basingstoke

- KONAK-DÖNMEZ [2015]: Waves of Social Movement Mobilizations in the Twenty-First Century - Challenges to the Neoliberal World Order and Democracy. Lexington Books, Langham

- KÖKÇE, Halime [2011]: AK Parti ve Kürtler. Okur Kitapliği, Isztambul

- KRAMER, Heinz [2000]: A Changing Turkey: The Challenge to Europe and the United States. Brookings Institution Press, Washington, DC

- KUMKALE, Tahir Tamer [2007]: R. Tayyip Erdoğan Kimdir. Pegasus, Isztambul

- KURU-STEPAN [2012]: Democracy, Islam and Secularism in Turkey. Columbia University Press, New York

- KUŞTEPELİ, Yeşim: Socio-Economic Development and Democratic Consolidation in Turkey. In: Müge Aknur (ed.) [2012]: Democratic Consolidation in Turkey. UniversalPublishers, Boca Raton

- LÜKÖ Dénes [2003]: A demokratikus államokban a civil-katonai kapcsolatok legfontosabb jellemzői, törvényi és intézményi háttere, levonható következtetések. In: Hadtudomány. 2. szám. p. 17-35

- MARCINKÓ, Éva: A Gülen-mozgalom jelentősége Törökországban. in: Korunk, 29/6 (2018), pp. 52-60

- MARSZAŁEK-KAWA-BURAK: The Political System of the Republic of Turkey, Past and Present. in: Przegląd Politologiczny, 9/3 (2018), pp. 96-108

- MÁRTON Andrea [2011]: A civil társadalom helyzetének és szerepének változásai. in: Biztonságpolitika.hu 
- MAVİ, İbrahim [2010]: Türkiye’de demokrasi ve Darbeler. TC. Afyon Kocatepe

Üniversitesi, Afyonkarahisar

- MIŞ-DURAN [2018]: 24 Haziran Seçim Sonuçları Analizi. SETA, Ankara

- MIŞ-GÜLENER-COŞKUN-DURAN-AYVAZ [2016]: Demokrasi Nöbetleri - Toplumsal Algıda 15 Temmuz Darbe Girişimi. SETA, Ankara

- MIŞ-ENSAROĞLU-ULUTAŞ-ÜNAY-ÇELİK-ÇAĞLAR (eds.) [2014]: 2014'te Türkiye. SETA, Ankara

- MENEK, Abdulkadir [2013]: Kürt Meselesi ve Said Nursi. Nesil Yayın Grubu, Isztambul

- MUFTI, Malik: The AK Party's Islamic Realist Political Vision: Theory and Practice. In:

Politics and Governance, 2014, Volume 2, Issue 2, pp. 28-42

- NARLI, Nilüfer [2005]: Civil-Military Relations in Turkey. in The Evolution of CivilMilitary Relations in South East Europe. Continuing Democratic Reform and Adapting the Needs to Figthing Terrorism. (eds: FLURI-GUSTENAU-PANTEV). Physica-Verlag, Heidelberg, pp. 229-258.

- N. RÓZSA Erzsébet [2015]: A török külpolitika irányai. KKI Elemzések

- ÖNIŞ-RUBIN (szerk.) [2003]: The Turkish Economy in Crisis: Critical Perspectives on the 2000-1 Crises. Frank Cass and Company Limited, London

- ÖZBAY-BESLİ [2010]: R. Tayyip Erdoğan - Bir Liderin Doğuşu. Meydan, Isztambul - ÖZBUDUN, Ergun: AKP at the Crossroads: Erdoğan's Majoritarian Drift. in: South European Society and Politics, 19/2 (2014) pp. 155-167

- ÖZBUDUN, Ergun [2015]: Pending Challenges in Turkey's Judiciary. in Aydın-Düzgin et al. Global Turkey in Europe III - Democracy, Trade, ande the Kurdish Question in TurkeyEU-Relations. Edizioni Nuova Cultura, Róma

- ÖZBUDUN-GENÇKAYA [2009]: Democratization and the Politics of Constitution-making in Turkey. Central European University Press, Budapest

- ÖZCAN-ELMAS-KUTLAY-MUTUŞ [2009]: Bundan sonrası?: senaryo analizleriyle Türkiye, AB ilişkileri. USAK Yayınları, Ankara 
- ÖZCAN, Ali Kemal [2012]: Turkey's Kurds: A Theoretical Analysis of the PKK and Abdullah Ocalan. Routledge, Abingdon

- ÖZCAN, Mutallip [2009]: Temel Dayanakları Bakımından Demokrasi: Antik ve Modern. in: Toplum ve Demokrasi, Vol.3, No.6-7, p. 125-148.

- ÖZÇELIK, Necdet [2016]: PKK ve Bombalı Araç Saldırıları. SETA, Ankara - ÖZDALGA, Haluk [2005]: Kötü yönetilen Türkiye: örnek vaka DSP. Kitap Yayıvi, Isztambul

- ÖZER, Ahmet [2013]: Kürtler Cumhuriyet'e Neden İsyan Etti?. Hemen Kitap, Isztambul - ÖZER, Mustafa [2004]: Türkiye Ekonomisi. Eskişehir Üniversitesi. Eskişehir - ÖZGÜLER, Verda Canbey [2013]: Avrupa ve Türkiye Işsü̈cü Piyasalarının Karşılaştırmalı Analizi. Cinius Yayınları Akademik, Isztambul

- ÖZKORAY-ÖZKORAY [2013]: Bireyselleşme ve Demokrasi. Gezi Fenomeni. İdea politika yayınları, Isztambul

- ÖZOĞLU, Hakan [2004]: Osmanlı devleti ve Kürt milliyetçiliği. Kitap Yayınevi, Isztambul - ÖZTÜRK, Ahmet Erdi: The Presidential Election in Turkey: History and Future Expectations. in: Contemporary Southeastern Europe, 1/2 (2014) pp. 110-118

- ÖZTÜRK, Murat [2012]: Agriculture, Peasantry and Poverty in Turkey in the Neo-liberal Age. Wageningen Academic Publishers, Wageningen

- RODRIK, Dani: Ergenekon and Sledgehammer: Building or Undermining the Rule of Law. in: Turkish Policy Quarterly 10/1 (2011) pp. 99-109

- ŞAHBAZ, Yunus: Ankara'da “Nerelisin, Kimlerdensin” Sarmall. in: Kriter Dergisi, 33/3 (2019), pp. 42-45

- SAKALLIOĞLU, Ümit Cizre. Parameters and Strategies of Islam-State Interaction in Republican Turkey. in: International Journal of Middle East Studies, 28/2 (1996), pp. 231251.

- SAKALLIOĞLU, Ümit Cizre [2008]: Secular and Islamic Politics in Turkey - the making of the Justice and Development Party. Routledge, Abingdon 
- SARAÇOĞLU, Cenk [2011]: Kurds of modern Turkey: migration, neoliberalism and exclusion in Turkish society. Tauris Academic Studies, New York

- SARTORI, Giovanni [1999]: Demokrácia. Osiris, Budapest

- SCHIFF, Rebecca L.: Civil-Military Relations Reconsidered: A Theory of Concordance. in Armed Forces and Society 22/1 (1995) pp. 7-24.

- SEYMOUR LIPSET, Martin [1960]: Political Man: The Social Bases of Politics. Doubleday, New York

- SHORAKA, Kirsten [2010]: Human Rights and Minority Rights in the European Union. Routeledge, Abingdon

- SLOAT, Amanda [2018]: The West's Turkey Conundrum. Brookings - Robert Bosch Foundation Transatlantic Initiative, Washington DC

- SOMER, Murat: Whither with Secularism or Just Undemocratic Laiklik? The Evolution and the Future of Secularism Under the AKP. in: Valeria Talbot (ed.) [2015]: The Uncertain Path of the 'New Turkey'. ISPI, Milan, pp. 23-48

- SOYAK, Hasan Rıza [1973]: Atatürk’ten Hatıralar, Yapı Kredi Yayınları, Isztambul

- SZIGETVÁRI Tamás: Az iszlám jelenléte a török gazdaságban. in: Vásáry István (szerk.):

Törökország és az iszlám. Az iszlám szerepe Törökország EU-csatlakozásának megítélésében, Acta et Studia VII, Avicenna Közel-Kelet Kutatások Intézete, Piliscsaba, 2008, pp. 51-78

- SZIGETVÁRI Tamás: Törökország gazdasági átalakulása és külgazdasági expanziója. In: Külügyi Szemle, 12/1 (2013) pp. 22-38

- TAN, Altan [2009]: Kürt Sorunu - Ya Kardeşlik, Ya Hep Birlikte Kölelik. Timaş Yayınları, Isztambul

- TAŞ, Hakkı: The 15 July abortive coup and post-truth politics in Turkey. in: Southeast European and Black Sea Studies, 18/1 (2018.a), pp. 1-19

- TAŞ, Hakkı: Contained Uncertainty: Turkey's June 2018 Elections and Their Consequences. in: GIGA Focus, Middle East, 4 (2018.b), pp. 1-12 
- TAŞDEMIR-SARAÇLI: Avrupa Birliği ve Türkiye Perspektifinden Azınlık Hakları Sorunu. in: Uluslararası Hukuk ve Politika 2/8 (2007) pp. 25-35

- TATHAM, Allan [2009]: Enlargement of the European Union. Kluwer Law International, Alphen an der Rijn

- TEKIN, Ozan [2014]: Factories of Memory: Cinematic Representations of the 12 September Military Coup. Anchor Academic Publishing, Hamburg

- TERTEROV-ROSENBLATT (szerk.) [2006]: Turkey: A Business and Investment Review. GMB Publishing, London

- TITTENSOR, David [2014]: The House of Service: The Gulen Movement and Islam's Third Way. Oxford University Press, Oxford

- TOPAK, Suat Tayfun: Anarşizm ve Gezi Parkı Olayları. in: Turkish Studies - International Periodical For The Languages, Literature and History of Turkish or Turkic 9/5 (2014) pp. 1931-1951

- TOPDEMIR, Ramazan [2014]: Atatürk'ten Erdoğan'a Kürt Politikası. Parola Yayınları, Isztambul

- TORUK-GÜRAN: 17 Aralık Sürecinde Türkiye'de Yaşanan 2014 Yerel Seçimleri. in: Türkiyat Araştırmaları Dergisi 36 (2014) pp. 281-297

- TORUK-OLKUN: Ekonomi-Politik Bağlamda Yaşanan AK Parti-Cemaat Olaylarının Türk Basınına Yansımaları: Yeni Şafak, Star, Zaman, Bugün ve Milliyet Gazeteleri Örneği. in: Türkiyat Araştırmaları Dergisi 35 (2014) pp. 377-400

- TURAN, Menaf: Türkiye'nin Yeni Yönetim Düzeni: Cumhurbaşkanlığı Hükümet Sistemi. in: Social Sciences Research Journal, 7/3 (2018), pp. 42-91

- TÜRK, Bahadır [2014]: Muktedir - Türk Să̆ Geleneği ve Recep Tayyip Erdoğan. İletişim Yayıncılık, İstanbul

- TÜRKMEN, Taha Uğur [2008]: Milletin adamları. Brifing, Isztambul

- TÜRKÖNE-YAYMAN (szerk.) [2009]: Kürt meselesi nasıl çözülmez?: demokratik çözümden milli birlik projesine. Birey Eğitim Yayınları, Isztambul 
- TÜRSAN Huri [2004]: Democratisation in Turkey - The Role of Political Parties. P.I.E. Peter Lang, Brüsszel

- UGUR - YANKAYA:Policy Entrepreneurship, Policy Opportunism, and EU

Conditionality: The AKP and TÜSİAD Experience in Turkey. in: Governance, 21/4 (2008) pp. 479-631.

- ULUM, Ömer Gökhan [2014]: Bir Millet Uyandı : Recep Tayyip Erdoğan Diyor ki. Palmiye, Isztambul

- USLU, Emrullah [2009]: The Transformation of Kurdish Political Identity in Turkey: Impact of Modernization, Democratization and Globalization. ProQuest, Ann Arbor - UYSAL, Cemal [2008]: DP'den - AKP'ye özgürlük ve zenginlik mücadelesi: demokrasi, politika ve ekonomi üzerine görüşler. Yargı Yayınevi, İzmir

- ÜLSEVER, Cüneyt [2011]: Yeni-Osmanlıcılık ve Kürt Açılımı. Kırmızı kedi, Isztambul - ÜNALAN, Ömer [2011]: AKP'nin Kürt Açılımı ve Tek Türkiye. Yolculuk Yayınevi, Isztambul

- ÜNALAN, Ömer [2012]: Cemaat gerçeği ve AK Parti. Öteki Adam yayınları, Isztambul - ÜNSAL, Saha [1996]: Dr. Hikmet Kivilcimli ve Vatan Partisi. Akdeniz Üniversitesi, Antalya

- VANDELIPPE, John M. [2005]: The Politics of Turkish Democracy: Ismet Inönü and the Formation of the Multi-Party System, 1938-1950. State University of New York Press, Albany

- VÁSÁRY István [2008]: Törökország és az iszlám: az iszlám szerepe Törökország EUcsatlakozásának megitélésében. Avicenna Közel-Kelet Kutatások Intézete, Budapest

- VIDÁK Rózsa: Változó identitások: kurdok a török nemzetállamban. In: Külügyi Szemle, 6/4 (2007) pp. 43-71

- VURUCU, İkbal [2012]: Sona Doğru: Kürt açılımı. Sarkaç Yayınlar, Ankara

- WATTS, Nicole F. [2010]: Activists in Office: Kurdish Politics and Protest in Turkey. University of Washington Press, Seattle 
- WILLIAM, John Allen [2007]: Political science perspectives on the military and civil-military relations. in: Social Sciences and the Military An interdisciplinary overview (ed: CAFORIO, Giuseppe), Routledge, New York, pp. 89-105

- WITTE, Bruno de [2000]: European Union's approach to ethnic minorities. European University Institute, Robert Schuman Centre, San Domenico di Fiesole

- YALÇIN-YARDAKUL [1999]: Bay Pipo / Bir MíT Görevlisinin Sıradışı Yaşamı: Hiram Abas. Doğan Kitap, Isztambul

- YAŞAR, Süleyman [2011]: Derin Ekonomi: Cumhuriyetin Finansal Şifreleri. Etkileşim Yayınları, Isztambul

- YAVUZ, Hakan [2005]: Modernleşen Müslümanlar - Nurcular, Nakşiler, Milli görüş ve AK Parti. Kitap, Isztambul

- YAVUZ, Hakan [2009]: Secularism and Muslim Democracy in Turkey. Cambridge University Press, Cambridge

- YAVUZ, Hakan [2006]: The Emergence of a New Turkey - Democracy and the AK Parti. The University of Utah Press, Salt Lake City

- YAVUZ, Hakan [2011]: Laiklik, Demokrasi, Kürt Sorunu ve İslam - Erbakan'dan Erdoğan'a.Kitap yayınevi, Isztambul

- YANIKKAYA-PABUÇCU: Causes and solutions for the stagnation of Islamic banking in Turkey. in: ISRA International Journal of Islamic Finance, 9/1 (2017), pp.43-61

- YAYLA, Ahmet S.: The Reina Nightclub Attack and the Islamic State Treat to Turkey. in: CTC Sentinel, 10/3 (2017), pp. 9-16

- YAYLA, Atilla: July 15: The Glorious Resistance of Turkish Democracy. in: [2017]:

ATAMAN, Muhittin (ed): July 15 Coup Attempt in Turkey - Context, Causes and Consequences, SETA, Ankara, pp. 19-66

- YEL-NAS: After Gezi: Moving Towards Post-Hegemonic Imagination in Turkey. in: Insight Turkey, 15/4 (2013) pp. 177-190 
- YEŞILAADA, Birol A.: The future of Erdoğan and the AKP. in: Turkish Studies, 17/1 (2016), pp. $19-30$

- YEŞILADA-RUBIN [2011]: Islamization of Turkey under the AKP Rule. Routledge, Abingdon

- YİĞİT, Mustafa [2013]: Gezi Parkı Eylemlerinin Görünen Yüzü. TASAV, Ankara

- YİĞİTER, Cenk: Erdoğan'nın Otolimitasyon Deklarasyonu, OHAL ve Akademik Özgürlük. in: Ankara Barosu Dergisi, 74/3 (2016), pp. 467-482

- ZIMMERMANN, Çağla [2014]: The Gezi Park Demonstrations 2013: A Case Study of Turkey. Webster University, Bécs 


\section{Internetes források}

- AK PARTI: Kurum Kimliği Kllavuzu (http://www.akpartiafyon.com/uploaded/dosya/16-082013-S9oVy-Kurumsal-Kimlik.pdf) Letöltve: 2018. november 11.

- AKYOL, Taha: Nüfusumuz 82 milyon (https://www.karar.com/yazarlar/tahaakyol/nufusumuz-82-milyon-9139?fbclid=IwAR1zwpGU8F1w9C58WzXm92YUU9kYrWsX45yAHwcsN87fJy7e-Stob-bZb0\#) letöltve: 2019. február 4.

- ALPAN, Başak: “Europe-as-Hegemony” and Discourses in Turkey after 1999: Dialogue with the Europeanisation Literature (http://aei.pitt.edu/52086/1/ALPAN.pdf) Letöltve: 2019. január 11.

- ARANGO, Tim: Turkish Leader, Using Conflicts, Cements Power (http://www.nytimes.com/2014/11/01/world/europe/erdogan-uses-conflict-to-consolidatepower.html?_r=0) Letöltve: 2015. június 29.

- AYDIN-ÇAKIR: Political Islam in Turkey (http://aei.pitt.edu/11663/1/1490.pdf) Letöltve:

2015. augusztus 2 .

- BAKIRCI, Cem: Anayasa Platformu - Vatandaş Toplantısı"nın Erzurum 'daki etabına Büyükşshir Belediye Başkanı Ahmet Küçükler'in konuşması damgasını vurdu (http://www.erzurumajans.com/mobile/kucukler-ile-bdpli-buldanin-bayrak-milletgerilimi_16229h.html) Letöltve: 2019. január 11.

- BALCI, Bayram: The AKP/Gülen Crisis in Turkey: Consequences for Central Asia and the Caucasus.

(http://www.sciencespo.fr/ceri/sites/sciencespo.fr.ceri/files/PolicyBrief16\%20April2014.p df) Letöltve: 2015. június 23.

- BANKO-BABAOĞLAN: Gezi Parkı Sürecine Dijital Vatandaş'ın Etkisi(http://www.geziparkikitabi.com/ekitap/GeziParkiKitabi.pdf) Letöltve: 2015. július 5.

- BEZCİ-BORROZ: The renewed Turkey-PKK conflict has shattered the illusion that Kurds can participate legitimately in Turkey's political system (http://eprints.lse.ac.uk/70965/1/blogs.lse.ac.uk-The\%20renewed\%20TurkeyPKK\%20conflict\%20has\%20shattered\%20the \%20illusion\%20that $\% 20$ Kurds $\% 20$ can $\% 20$ participate\%20legitimately\%20in.pdf) Letöltve: 2019. január 1. 
- BOSTANCI-UÇMA-YETIŞ: Muhafazakar Demokrasi

(http://www.murtazayetis.com/MurtazaYetis_Files/demokrasi.pdf) Letöltve: 2015. augusztus 2 .

- CAGAPTAY-JEFFREY: Turkey's 2014 Political Transition - From Erdogan to Erdogan? (http://www.washingtoninstitute.org/uploads/Documents/pubs/PolicyNote17_CagaptayJe ffrey_2.pdf) Letöltve: 2015. június 23.

- CALLIGARIS, Marius: Municipal Elections in Turkey - Erdogan's Popularity Anabated (http://www.bundesheer.at/pdf_pool/publikationen/ifk_monitor_22_int_municipal_electio ns_in_turkey_mc.pdf) Letöltve: 2015.június 23.

- ÇELIKYAY, Hicran: Yeni Büyükţehir Yasasý Perspektifinde 2014 Yerel Seçimleri (http://file.setav.org/Files/Pdf/20140507122428_yeni-buyuksehir-yasasi-perspektifinde2014-yerel-secimleri-pdf.pdf) Letöltve: 2015. június 23.

- COUNTRY ECONOMY: TURKEY GDP - Gross Domestic Product

(https://countryeconomy.com/gdp/turkey?year=2002) Letöltve: 2019. január 11.

- EGERESI Zoltán: A török demokrácia és pártrendszer 60 éve.

(http://www.grotius.hu/doc/pub/NFJSYE/2010_81_egeresi_zoltan_torok_partok.pdf)

Letöltve: 2018. november 11.

- EGERESI Zoltán: A török hadsereg változó szerepe: kiszorulás a hatalomból? (http://biztonsagpolitika.hu/wp-content/uploads/2015/04/Egeresi-Zoltan-A-torok-hadseregvaltozo-szerepe.pdf) Letöltve: 2018. november 11.

- EGERESI Zoltán: Repedezö nemzetállam? A török nemzetépités és kurd nemzetalkotás. (http://www.grotius.hu/doc/pub/CFLIIE/2011_21_egeresi_zolt\%C3\%A1n_\%20repedezo_ne mzetallam.pdf) Letöltve: 2018. november 11.

- ERINÇ, Orhan: DP Niyetlenmişti AKP Uyguluyor...

(http://www.cumhuriyet.com.tr/koseyazisi/580169/DP_Niyetlenmisti_AKP_Uyguluyor....htm 1) Letöltve: 2019. január 11.

- FEKETE József: A Gülen mozgalom tevékenysége a világban, különös tekintettel Délkelet Európára

(http://www.mrtt.hu/vandorgyulesek/2014/01/fekete_jozsef.pdf) Letöltve: 2015. június 23. 
- GEYVE MEDYA: İstanbul Büyükşehir Belediye Başkanı Kadir Topbaş istifa etti (https://www.geyvemedya.com/istanbul-buyuksehir-belediye-baskani-kadir-topbas-istifaetti/) Letöltve: 2018. december 21.

- GÖNENÇ, Levent M.: Uygulamada Cumhurbaşkanlığı Hükümet Sistemi. (http://www.tepav.org.tr/upload/files/1526884486-

7.Uygulamada_Cumhurbaskanligi_Hukumet_Sistemi.pdf) Letöltve: 2018. december 16.

- HABER MERKEZİ: Tek millet, tek devlet, tek din, tek bayrak (https://www.evrensel.net/haber/28424/tek-millet-tek-devlet-tek-din-tek-bayrak) Letöltve: 2019. január 11.

- HABER SOM: Kadir Topbaş meğer FETÖ’ye kız vermiş; damadı FETÖ’den gözaltında! (http://www.habersom.com/kadir-topbas-meger-fetoye-kiz-vermis-damadi-fetodengozaltinda/) Letöltve: 2018. december 21.

- HANSEN, Suzy: A Guy Who Lives in Pennsylvania May Be Taking Down the Entire Turkish Government - A profile of Fetullah Gulen, the prime minister's greatest enemy (http://www.newrepublic.com/article/116044/fethullah-gulen-turkish-prime-ministererdogans-biggest-rival) Letöltve: 2015. június 28.

- JAGER, Jeff: Understanding the Gülen Movement (http://www.css.ethz.ch/content/dam/ethz/special-interest/gess/cis/center-for-securitiesstudies/resources/docs/Small\%20Wars\%20Journal\%20\%20Understanding\%20the\%20G\%C3\%BClen\%20Movement.pdf) Letöltve: 2018. december 31 .

- KISS, István: A török igazszágszolgáltatás miatt aggódik az Európa Tanács (http://kitekinto.hu/europa/2012/06/26/a_torok_igazszagszolgaltatas_miatt_aggodik_az_europ a_tanacs\#.VSP_19yUc3c.) Letöltve: 2015. június 23.

- KIVRIKOGLU, Hüseyin: Ecevit'ten destek istedim. (http://www.milliyet.com.tr/1999/12/25/siyaset/siy02.html) Letöltve: 2015. június 23.

- KOÇ, Yıldırım: AB’nin Asker Düşmanlı̆̆ı.

(http://www.yildirimkoc.com.tr/usrfile/1325435005a.pdf) Letöltve: 2018. november 11. 
- KOENIG, Peter: Turkey - a Failed Coup or a Paradigm Shift Not Only in MENA But Also in the WORLD?

(https://www.21 cir.com/2016/08/turkey-failed-coup-or-a-paradigm-shift-in-the-middleeast-in-the-world/) Letöltve: 2019. január 1.

- KONDA (2014) : 30 Mart Yerel Seçimler Sonrasý Sandýk ve Seçmen Analizi (http://www.konda.com.tr/tr/raporlar/KONDA_30Mart2014_YerelSecimAnalizi.pdf) Letöltve: 2015. június 23.

- KONDA (2018): 10 Yılda Ne Değişti?

(https://interaktif.konda.com.tr/tr/HayatTarzlari2018/\#7thPage/1) Letöltve: 2019. február 2.

- KÖPRÜLÜ, İbrahim Seral: Bir Başarı Hikayesi: Grafiklerle Türk Ekonomisinin 11 Yılı (http://seralkoprulu.com/bir-basari-hikayesi-grafiklerle-turk-ekonomisinin-11-yili/) Letöltve: 2015. július 5 .

- KURU, Ahmet: Changing Perspectives on Islamism and Secularism in Turkey: The Gülen Movement and the AK Party (http://gyv.org.tr/content/userfiles/pdf/makale-londahmet_kuru.pdf) Letöltve: 2015. június 23.

- KÜTAHYALI, Rasim Ozan: Ahmet Davutoğlu ve başkanlık sistemi (https://www.sabah.com.tr/yazarlar/kutahyali/2015/11/11/ahmet-davutoglu-ve-baskanliksistemi) Letöltve: 2018. december 21.

- NÉMET - SZALMA BAKSI: Belehalt sérüléseibe a túszul ejtett török ügyész (https://index.hu/kulfold/2015/03/31/tuszul_ejtettek_egyugyeszt_isztambulban/) Letöltve 2018. november 11 .

- NÉMETH György [1996]: A görög poliszvilág államai. Rubicon. (http://www.rubicon.hu/magyar/oldalak/a_gorog_poliszvilag_allamai/) Letöltve: 2015. május 02.

- ÖZEN, Hayriye: Bergama Mücadelesi: Doğuşu, Gelişimi ve Sonuçları (http://www.ayk.gov.tr/wp-content/uploads/2015/01/AYG\%C3\%9CN-Banu\%C5\%9EAKACI-Bilge-Ka\%C4\%9Fan-T\%C3\%9CRK\%C4\%B0YE\%E2\%80\%99DE- 
\%C3\%87EVREYE-DO\%C4\%9ERUDAN-ODAKLI-\%C3\%87EVREC\%C4\%B0-

HAREKETLER-VE-\%C3\%87EVRESEL-YAKLA\%C5\%9EIMLARI-

\%C3\%9CZER\%C4\%B0NE-B\%C4\%B0R-DENEME.pdf) Letöltve: 2015. július 5.

- ÖNIŞ, Ziya: Monopolizing the Center: The AKP and the Uncertain Path of Turkish

\section{Democracy}

(http://www.suits.su.se/polopoly_fs/1.200640.1408970851!/menu/standard/file/Onis\%20

Monopolizing\%20the\%20center-Final\%20Draft\%2019\%20August\%202014.pdf)

Letöltve: 2015. június 23.

- ÖZTÜRK, İbrahim: 2015 yılı: 'Korku ve umut arasında' Türk ekonomisi

(http://www.bugun.com.tr/ekonomi/2015-yili-korku-ve-umut-arasinda-turk-ekonomisihaberi/1422233) Letöltve: 2015. július 5.

- PAUL-SEYREK: Constitutional changes in Turkey: A presidential system or the president's system? (http://aei.pitt.edu/83866/1/pub_7374_conschangesinturkey.pdf) Letöltve: 2018. december 16.

- PÉNZVÁLTÓ, Nikolett: Délkelet-Törökország újra lángol (https://svkk.uninke.hu/document/svkk-uni-nke-hu-1506332684763/svkk-elemzesek-2016-8-delkelettorokorszag-ujra-langol-penzvalto-n.original.pdf) Letöltés: 2019. január 1.

- PETERS, Anne: The Turkish Operation in Afrin (Syria) and the Silence of the Lambs (http://www.mpil.de/files/pdf5/Peters_EJIL_Talk_Turkey_Syria1.pdf) Letöltve: 2018. június 30 .

- RODRIK, Dani: Plot Against the Generals (https://www.sss.ias.edu/files/pdfs/Rodrik/Commentary/Plot-Against-the-Generals.pdf) Letöltve: 2015. június 24.

- SIRKECI, Ibrahim: Exploring the Kurdish Population in the Turkish Context (http://www.protobulgarians.com/Drugi\%20temi/Sirkeci_2000_exploringtheKurdish_Ge nus.pdf) Letöltve: 2015. június 24.

- TAŞGETIREN, Ahmet: Dershaneleri yazmak (http://gundem.bugun.com.tr/dershaneleriyazmak-yazisi-213714) Letöltve: 2015. június 28. 
- TALAS, Mustafa: SIVILL TOPLUM KURULUŞLARI ve TÜRKIYE PERSPEKTİFİ (http://www.tubar.com.tr/TUBAR\%20DOSYA/talas_mustafa\%20387-401.pdf) Letöltve: 2015. július 5 .

- THALJI, Mohammed Jaber: Prep Schools, Elections and AKP-Gulen Clashes (http://studies.aljazeera.net/ResourceGallery/media/Documents/2014/4/17/201441794023 143580Prep\%20Schools.pdf) Letöltve: 2015. június 23.

- THE ECONOMIST: The retreat of global democracy stopped in 2018 (https://www.economist.com/graphic-detail/2019/01/08/the-retreat-of-global-democracystopped-in2018?fbclid=IwAR25i6VJcEIpsgrutuo_J1UBnyLt7KZ8ANSkk0JhykxOxnHB1HkM7QR JMYI) Letöltve: 2019. március 6.

- THE GUARDIAN: Leaked tapes prompt calls for Turkish PM to resign (https://www.theguardian.com/world/2014/feb/25/leaked-tapes-calls-erdogan-resignturkish-pm) Letöltve: 2019. január 5.

- ÜSKÜL, Zafer: Turkey's Democratization and the European Union (http://turkishpolicy.com/Files/ArticlePDF/turkeys-democratization-and-the-europeanunion-fall-2002-en.pdf) Letöltve: 2019. február 2.

- YAKUT, Mehmet: Osmanlı Devleti ve Türkiye'de Okuryazarlık Oranları (https://mehmetyakut.wordpress.com/2016/10/06/osmanli-devleti-ve-turkiyedeokuryazarlik-oranlari/?fbclid=IwAR2SJr_K5Q6Fg5A_TJ1K70o6xpFdk6K0D4ZL_hTBEb-8J2HyVDhrO5og2U) Letöltve: 2019. február 4.

- YILMAZ, Yasin: Dindar nesil yetiştireceğiz (https://www.yenisafak.com/gundem/dindarnesil-yetistirecegiz-2424175) Letöltve: 2019. február 2.

- ZGUT, Edit: Erdogan a múltba kormányozná az „Új Törökországot” (http://valasz.hu/publi/torok-valasztas-110046) Letöltve: 2018. november 11. 